\title{
Digital Models of Ground-Water Flow in the Cape Cod Aquifer System, Massachusetts
}

\author{
WATER RESOURCES INVESTIGATIONS \\ OPEN-FILE REPORT 80-67
}

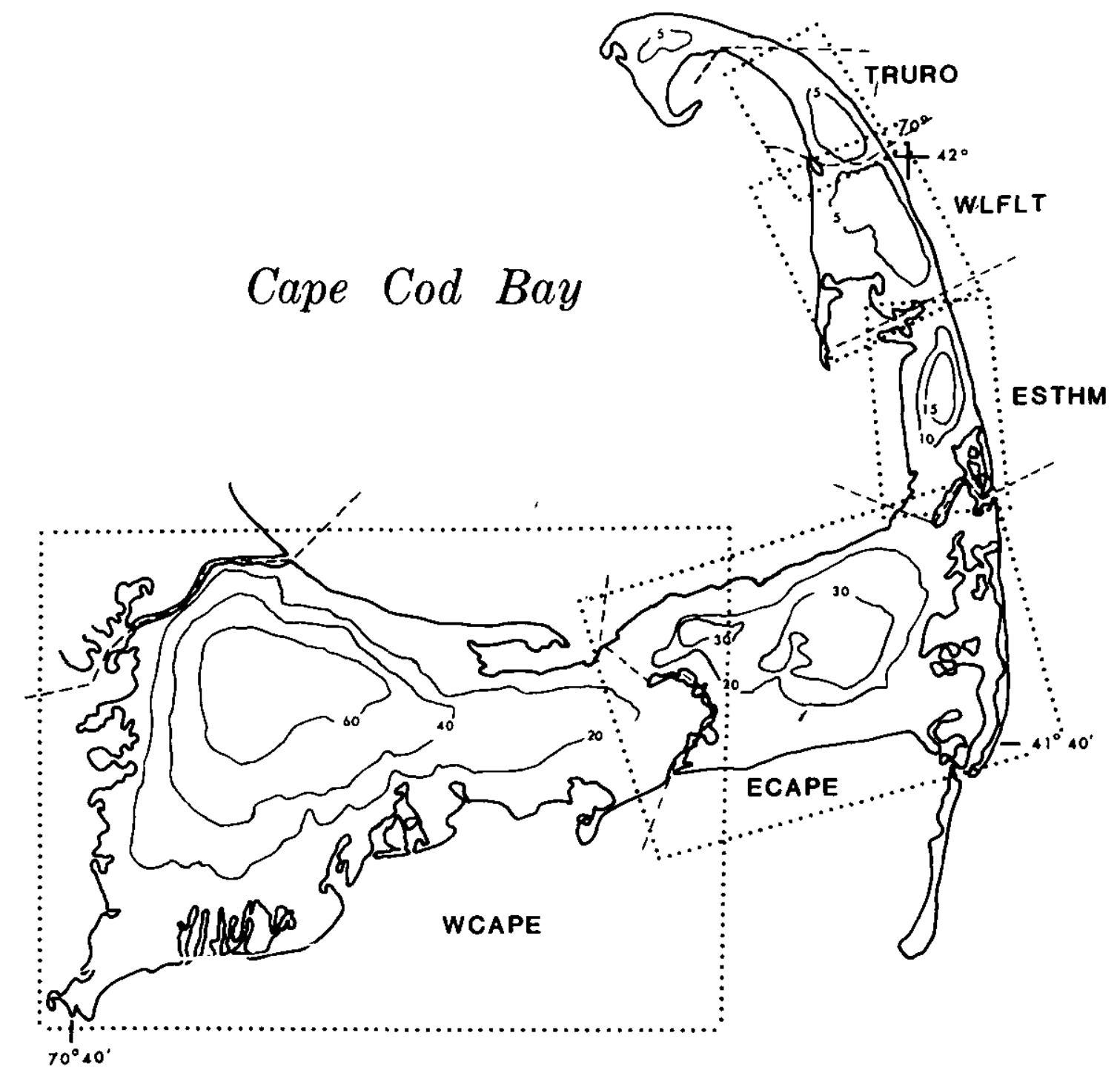

UNITED STATES DEPARTMENT OF THE INTERIOR GEOLOGICAL SURVEY

PREPARED M COOPERATION WITH THE

COMMONWEALTH OF MASSACHUSETTS , WATER RESOURCES COMMISSION, BARNSTABLE COUNTY, AND THE NATIONAL PARK SERVICE 
DIGITAL MODELS OF GROUND-WATCR FLOW IN THE :

CAPE COD AQUIFER SYSTEM, MASSACHUSETTS

By John H. Guswa and Denis R. LeBlanc

\section{U.S. GEOLOGICAL SURVEY}

Water-Resources Investigations

Open-File Report 80-67

Prepared in cooperation with the

Commonwealth of Massachusetts, Water Resources Commission

Barnstable County, and the

National Park Service 
UNITED STATES DEPARTMENT OF THE INTERIOR

JAMES G. WATT, Secretary

GEOLOGICAL SURVEY

Dallas L. Peck, Director

For additional information, write to:

U.S. Geological Survey

150 Causeway Street, Suite 1001

Boston, MA 02114 


\section{CONTENTS}

Factors for converting inch-pound units to International System. of Units (SI) -

Abstract---_-_.

Introduction-:-1.-1

Background -.-

Purpose and scope-1.-

Hydrogeology of Cape Cod -

Geologic framework and water-bearing characteristics--

Hydraulic properties of sediments -

Analysis of specific-capacity data--

Aquifer test analyses -

Hydrologic system

Digital-simulation model-.-

Flow equation

Numer ical method--

Application of simulation model-

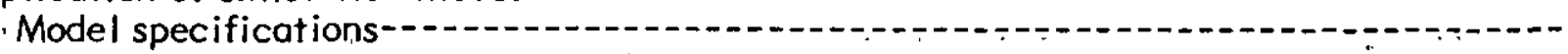

Water-transmitting properties of the aquifer-1-

Boundaries and hydraulic stresses .

Well discharge-1.

Boundary between fresh and saline water

Streams and marshes - Aquifer recher

Aquifer recharge-

Calibration of the steady-state flow models

Purpose and procedure

Results -- procen

$\therefore$ WCAPE model-1...

ECAPE model --

ESTHM model --1-1-0

WLFLT model -

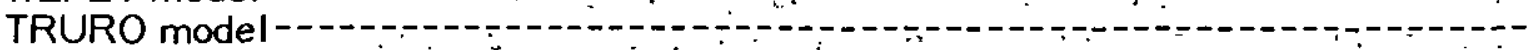

Summary and conclusions-

References---10

Supplemental data-model data, input documentation, and source code - 38

\section{ILLUSTRATIONS}

Page :

$\therefore . . \quad . \quad \ldots \quad$. . . . . Page

Figure 1. Physical features of Cape Cod -

2. Water-table map of Cape Cod showing the freshwater-flow systems and the approximate boundaries of the modeled areas

3-7. Plan view of finite-difference grids for:

3. WCAPE model-10

4. ECAPE model -

5. ESTHM model.

6. WLFLT model -

7. TRURO model -

8. Schematic representation of equivalent vertical hydraulic conductivity $-\ldots . . \quad 17$

9. Schematic hydrologic section of the seaward boundary of freshground-water flow-

10. Calculated and observed average water table, WCAPE model----:- 24

11. Calculated water table and interface between fresh and saline ground water for cross section A-A' 


\section{ILLUSTRATIONS (Continued)}

Figure 12. Calculated water table and interface between fresh and saline Page

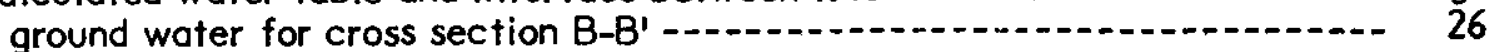

13. Calculated water table and interface between fresh and saline

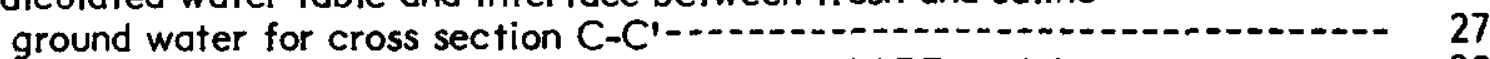

14. Calculated and observed average water table, ECAPE model -................- 29

15. Calculated water table and interface between fresh and saline

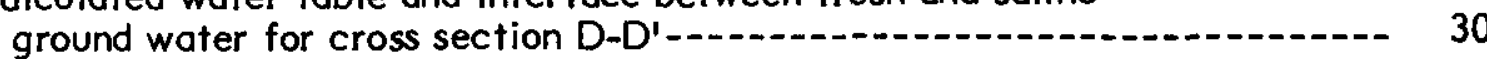

16-18. Calculated and observed average water table:

16. ESTHM model-1..- 32

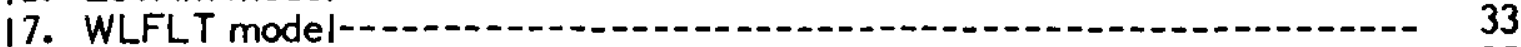

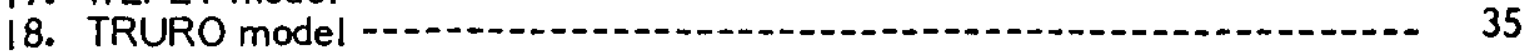

19. Calculated water table and inter face between fresh and soline ground water for cross section E-E' -

20-23. Transmissivity, WCAPE model:

20. Layer 1

21. Layer 2 -

22. Layer 3 -.-......

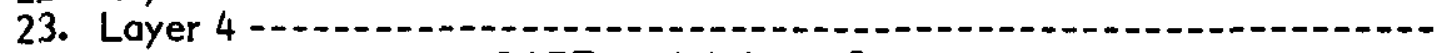

24. Hydraulic conductivity, WCAPE model, layer 5 ...........................

25-28. Ratio between lateral and vertical hydraulic conductivity, WCAPE model:

25. Layer 2 - Lay

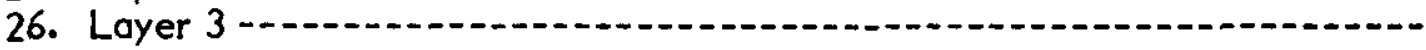

27. Layer 4 --

28. Layer 5 -...........

29-32. Transmissivity, ECAPE model:

29. Layer I - ECAPE model

30. Layer 2 -..-

31. Layer 3 -..-

32. Layer 4 --

33. Hydraulic conductivity, ECAPE model, layer 5 -

34-37. Ratio between lateral and vertical hydraulic conductivity, ECAPE model:

34. Layer 2 -

35. Layer 3 --...-

36. Layer 4 --.-.-

37. Layer 5 -

38-39. Transmissivity, ESTHM model:

38. Layer 5 - ESTHM

39. Layer 6 -

40. Hydraulic conductivity, ESTHM model, layer 7 ......................... 60

41-43. Ratio between lateral and vertical hydraulic conductivity, ESTHM model:

41. Layer 5--

42. Layer 6 -

43. Layer 7 -

44-46. Transmissivity, WLFLT model:

44. Layer 4

45. Layer 5 - 65

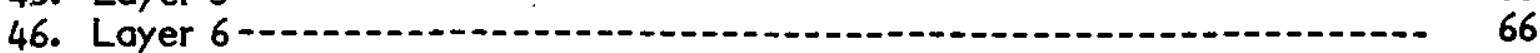

47. Hydraulic conductivity for WLFLT model, layer 7 ..................... 67

48-50. Ratio between lateral and vertical hydraulic conductivity, WLFLT model:

48. Layer 5-1.-...-

49. Layer 6--

50. Layer $7--\ldots$

51-52. Transmissivity, TRURO model:

51. Layer 5 5 . 71

52. Layer 6-12 
Figure 53. Hydraulic conductivity, TRURO model, layer 7

54-55. Ratio between lateral and vertical hydraulic conductivity, TRURO model: 54. Layer 5-..... 74

55. Layer 6-_... 75

56-60. Steady-state recharge:

56. WCAPE model-a

57. ECAPE model $-\cdots$

58. ESTHM model -

59. WLFLT model -.

60. TRURO model

\section{TABLES}

Table 1. Estimates of average hydraulic conductivity for lithologic types calculated from specific-capacity data-

2. Average hydraulic conductivity values for grouped lithologic types---

3. Descriptive information regarding finite-difference grids for modeled areas

4-8. Comparison of calculated nodal head values and observed average water
levels for the period 1963 to 1976 for selected wells:

4. WCAPE model -

5. ECAPE model $\cdots$

6. ESTHM model -1

7. WLFLT model -

8. TRURO model -

9. Values for transmissivity, average hydraulic conductivity, and ratio between lateral and vertical hydraulic conductivity used in model calibrations----- 39

10. Summary of well discharges represented in models

11. Input documentation-- 83

12. Computer source code 
FACTORS FOR CONVERTING INCH-POUND UNITS

TO INTERNATIONAL SYSTEM OF UNITS (SI)

The following factors can be used to convert inch-pound units to International System of Units (SI).

Multiply inch-pound units

By

To obtain SI Units

\begin{tabular}{|c|c|c|}
\hline foot $(f t)$ & 0.3048 & meter $(m)$ \\
\hline foot per day $(f t / d)$ & 0.3048 & meter per day $(m / d)$ \\
\hline \multicolumn{2}{|l|}{ foot per day per } & meter per day per \\
\hline foot $[/ \mathrm{ft} / \mathrm{d}) / \mathrm{ft} \underline{T}$ & 0.3048 & meter $1 / \mathrm{m} / \mathrm{d}) / \mathrm{m} T$ \\
\hline \multirow{3}{*}{$\begin{array}{l}\text { square foot per day }\left(\mathrm{ft}^{2} / \mathrm{d}\right) \\
\text { cubic foot per second }\left(\mathrm{ft}^{3} / \mathrm{s}\right) \\
\text { inch (in) }\end{array}$} & $9.290 \times 10^{-2}$ & square meter per day $\left(m^{2} / d\right)$ \\
\hline & $2.832 \times 10^{-2}$ & cubic meter per second $\left(\mathrm{m}^{3} / \mathrm{s}\right)$ \\
\hline & 2.54 & centimeter $(\mathrm{cm})$ \\
\hline inch per year (in/year) & 2.54 & centimeter per year $(\mathrm{cm} /$ year $)$ \\
\hline mile (mi) & 1.609 & kilometer $(\mathrm{km})$ \\
\hline gallon per minute (gal/min) & $6.310 \times 10^{-2}$ & liter per second $(\mathrm{L} / \mathrm{s})$ \\
\hline ohm-foot & 0.3048 & ohm-meter \\
\hline \multicolumn{3}{|c|}{$\begin{array}{l}\text { National Geodetic Vertical Datum of } 1929 \text { (NGVD of 1929): A geodetic datum derived } \\
\text { from a general adjustment of the first-order level nets of both the United States } \\
\text { and Canada, formerly called "Mean Sea Level. " NGVD of } 1929 \text { is referred to as sea } \\
\text { level in this report. }\end{array}$} \\
\hline
\end{tabular}


DIGITAL MODELS OF GROUND-WATER FLOW IN THE

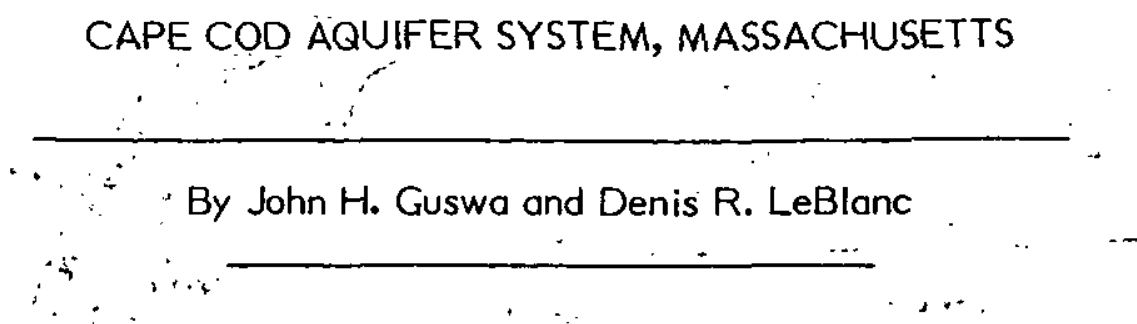

\section{ABSTRACT}

The Cape Cod aquifer system was simulated with three-dimensional finite-difference ground-water-flow models. Five areas were modeled to provide tools that can be used to evaluate the hydrologic impacts of regional water development and waste disposal.

The model boundaries were selected to represent the natural hydrologic boundaries of the aquifer. The boundary between fresh and saline ground water is treated as an interface along which there is no dispersion. The saline-water zone is treated as static (nonflowing).

Comparisons of calculated and observed values of head, position of the boundary between fresh and saline water, and ground-water discharge at locations where data are available indicate that the simulated ground-water reservoirs generally agree with field conditions.

Model analyses indicate that the total steady-state freshwater-flow rate through the five modeled areas is approximately 412 cubic feet per second.

\section{INTRODUCTION}

\section{Background}

Ground water is the principal source of freshwater for Cape Cod, Massachusetts. The Cape is composed of unconsolidated glacial moraines and outwash plains that form a hook-shaped peninsula extending 40 miles into the ocean (fig. I). It is separated from the mainland by a sea-level canal connecting Buzzards Bay and Cape Cod Bay. A lens-shaped reservoir of fresh ground water is maintained in dynamic equilibrium beneath the Cape by recharge from precipitation and discharge to the sea.

Increases in the number of year-round residents and summer vacationers have added to local and State government concern over increased water demands, deterioration of water quality, changes in water-table and pond levels, and ecologic changes caused by changes in salinity of brackish-woter bodies.

Monagement of ground-water resources generally encounters several problems. Hydrologic properties of aquifers are fundamentally dependent on geology, and their determination is usually complex and expensive. Local stresses can have regional hydraulic effects on an aquifer. Ground-water movement is slow; therefore, the consequences of management decisions may not be noticed for decades. The results may then be, for all practical purposes, irreversible. Ground-water movement cannot be observed directly and must be inferred from indirect measurements and abstract mathematical reasoning.

Flow in an aquifer can be described analytically by differential equations. These equations will yield direct solutions; however, owing to the complexity of most aquifer systems, direct solutions are generally not feasible. Approximate solutions of the flow equations describing aquifers with spatial variation of hydrologic properties and stresses and irregular geometries can be obtained using numerical methods. The reljability of these numerical solutions is dependent upon the accuracy of the input data and the size of the aquifer element which the flow equations describe. The use of a digital computer to obtain a numerical solution is called modeling the aquifer by digital simulation. 

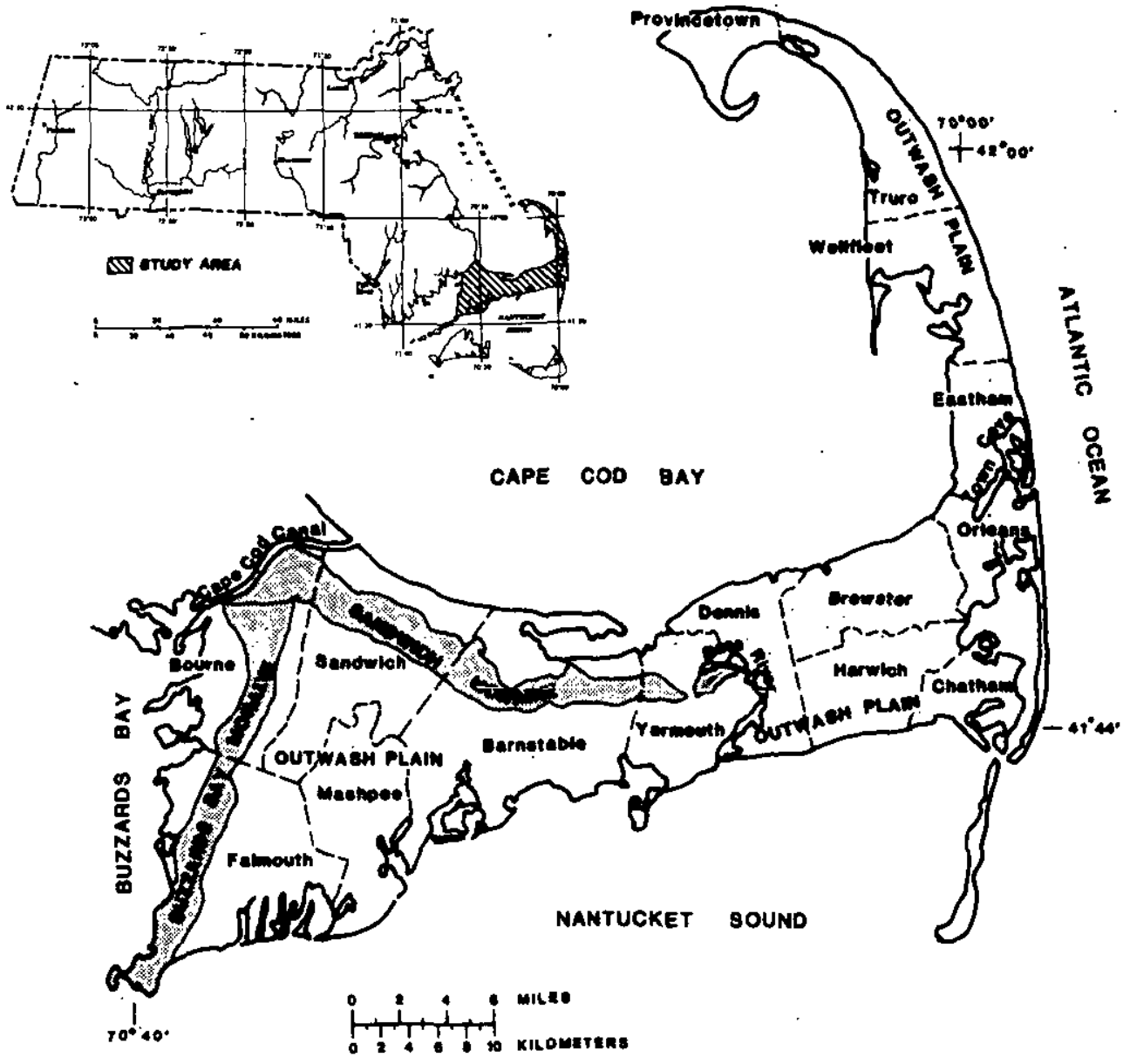

Figure 1.-- Physical features of Cape Cod (from 0ldale, 1977) 
The purpose of this report is to describe digital simulation models prepared as part of a 4-year study of the ground-water resources of Cape Cod in cooperation with the Massachusetts Water Resources Commission, Divisions of Water Resources and Water Pollution Control; Barnstable County; and the National Park Service.

This report describes the sources and types of data used in constructing five models, model calibration, and possible sources of inaccuracies of the results. The five modeled areas and their names are shown in figure 2.

The models provide information regarding the regional behavior of the aquifer system. Detailed analyses of local hydrologic conditions are beyond the scope of this study. The principles used to constuct these models can be used to construct more detailed models of smaller areas if sufficient data are available.

\section{HYDROGEOLOGY OF CAPE COD}

\section{Geologic Framework and Water-Bearing Characteristics}

The bedrock that underlies Cape Cod is overlain by unconsolidated sediments of Pleistocene and Holocene age (Oldale, 1976). The bedrock surface is irregular and is not exposed. It ranges in altitude from 80 feet below sea level near the Cape Cod Canal to more than 900 feet bèlow sea level near Provincetown (Oldale, 1969).

The Pleistocene sediments consist of unconsolidated sand, gravel, silt, clay, and till. They are part of the complex of end moraines and outwash plains of late Wisconsinan age that characterize coastal New York (Long Island), Rhode Island, and Massachusetts (OIdale, 1976).

Sandy till mixed with stratified sand, gravel, and silt forms the Buzzards Bay and Sandwich moraines (fig. 1). These moraines are low, broad north-and east-trending ridges of moderately rugged topography. East of the Bass River, the east-trending Sandwich moraine deposits are buried by outwash-plain deposits.

Extreme lithologic variation over short distances and depths to water generally greater than 30 feet have discouraged exploration for water supply in the moraine areas. Projected yields of $4.5 \mathrm{ft}^{3} / \mathrm{s}(2000 \mathrm{gal} / \mathrm{min})$ hove been reported (Thomas Mullen, Water Superintendent, Barnstable Fire District, oral commun., 1977) for 24-inch diameter gravel-packed wells screened in sand and gravel in the moraine area of Barnstable. Wells drilled in similar nearby areas of the moraine, however, have penetrated silt and clay layers which are several hundred feet thick and have been reported to be dry holes. The lack of test-hole information and the extreme lithologic variation in the moraine area does not permit stratigraphic correlation.

The western part of the outwash-plain deposits in Bourne, Sandwich, Falmouth, Mashpee, and western Barnstable is composed primarily of stratified sand and gravel but has local silt and clay layers. These deposits generally become finer grained with depth, especially to the south, where very fine sand, silt, and clay predominate below 100 .feet in many places.

The eastern part of the outwash plain, in eastern Barnstable, Yarmouth, Dennis, Brewster, Harwich, Chatham, and Orleans, is composed of stratified sand and gravel which, in places, is mixed with till and ice-contact deposits, and silt and clay. The northern section of this part of the outwash plain is generally coarser grained than the southern section and is mixed with or overlies very coarse grained ice-contact deposits and till, especially in Yarmouth, Dennis, and Chatham. To the south, clay and silt layers are commonly interbedded with sand and gravel. Along Nantucket Sound, the eastern part of the outwash plain is underlain by a silt and clay deposit which is thicker than 150 feet in places. The silt and clay are reported to have been deposited in a lake that occupied the present site of eastern Nantucket Sound (Oldale, 1976).

The lithologic variation within the outwash plain deposits is not as extreme as within the moraine areas, and well yields range from 0.45 to $1.56 \mathrm{ft} / \mathrm{s}(200$ to $700 \mathrm{gal} / \mathrm{min})$ or 0.05 to $0.16 \mathrm{ft}^{3} / \mathrm{s}$ ( 20 to $70 \mathrm{gal} / \mathrm{min}$ ) per foot of 24 -inch diameter gravel-packed screen.

North of the Sandwich moraine are deposits of sand and gravel which, in some areas, grade northward into finer grained deposits (silt and clay). Results of test drilling along the southern shore of Cape Cod Bay (from the Cape Cod Canal to Brewster) indicate that silt and clay layers, in places more than 100 feet thick, are commonly interbedded with the sand and gravel beds. 


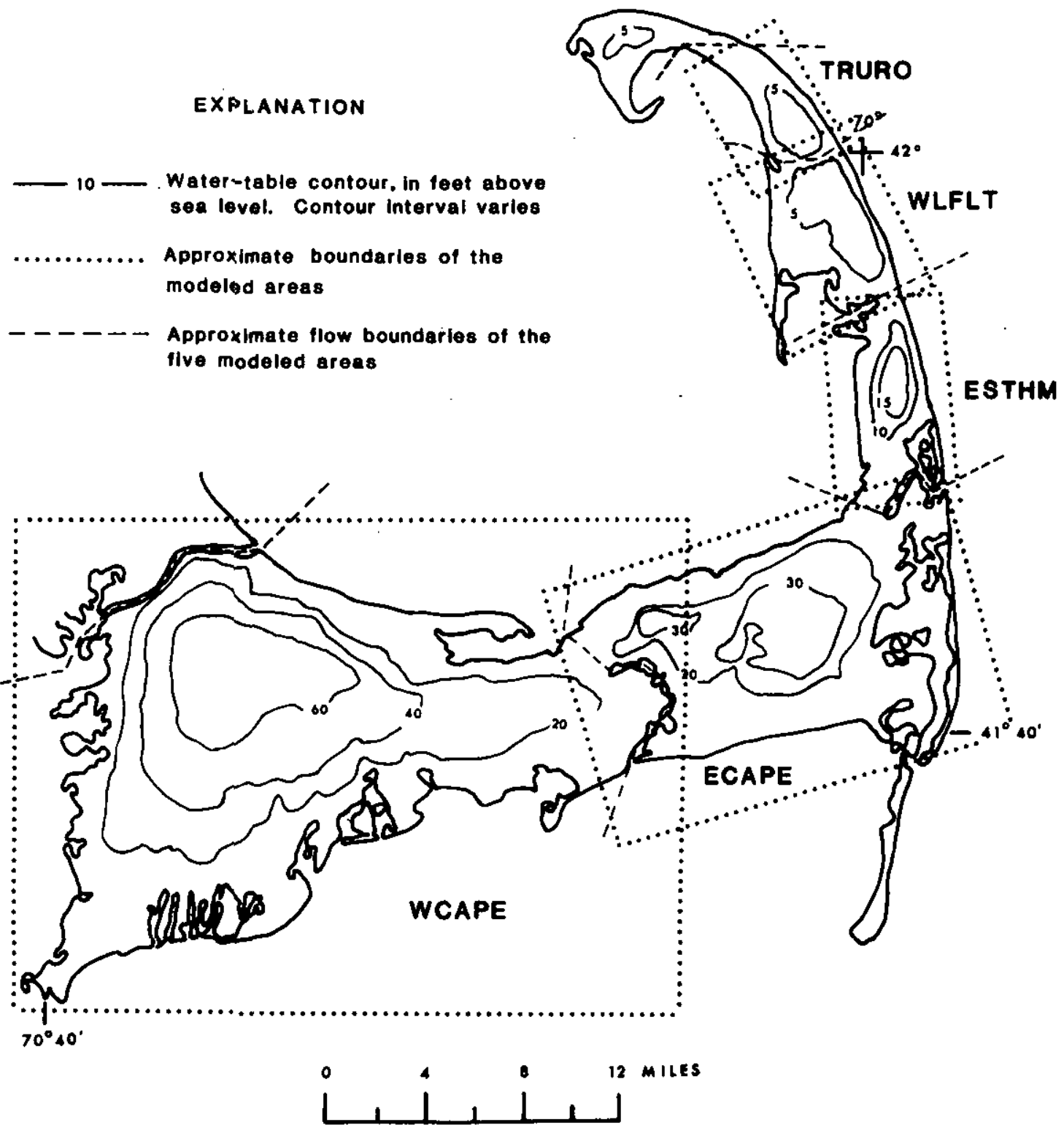

Figure 2.-- Water-table map of Cape Cod, May 25-27, 1976, showing the freshwater-flow systems and the approximate boundaries of the modeled areas 
These silt and clay deposits locally cause water to occur under confined conditions. At Corporation Beach in Dennis, a well drilled approximately 100 feet.landward of the shoreline penetrated freshwater (chloride concentration less than 250 milligrams per liter) to bedrock at a depth of 316 feet. The head at this site was 5 feet higher below a 35-foot-thick silt and clay layer than the head above the layer; the silt and clay was penetrated from 78 feet to 113 feet below land surface.

From Orleans to Truro, the Cape is underlain by glacial outwash deposits consisting primarily of sand and gravel interbedded with silt and clay. Exposures of these deposits along the eastern shore of the outer Cape indicate that the silt and clay layers are contorted and discontinuous. Lack of well-log data precludes determining areal extent of the silt and clay layers. The only large-scale water-supply system developed in these deposits is in the town of Truro.

Holocene deposits include the salt marshes, beaches, spits, and dunes. "They are composed of sand, silt, and clay. Few wells have been drilled in these deposits.

\section{Hydraulic Properties of Sediments}

The transmissivity of an aquifer may be estimated by multiplying a calculated or estimated hydraulic conductivity value by aquifer thickness. A more general method of calculating the transmissivity of an oquifer consisting of several hydrogeologic units is given by equation $\mathrm{l}$.

in which

$$
T=\sum_{i=1}^{n} \dot{K}_{i} m_{i}
$$

$\because \mathrm{T} \quad$ is the transmissivity $\left(\mathrm{L}^{2} / \mathrm{T}\right)$,

: $K_{i}$ is the hydraulic conductivity of the $i$ th hydrogeologic unit (L/T),

$m_{i}$ is the thickness of the $i$ th hydrogeologic unit (L), and

$n \quad$ is the number of hydrogeologic units within the the specified aquifer thickness.

\section{Analysis of Specific-Capacity Data}

The hydraulic conductivities of different lithologies on Cape Cod were estimated by analyzing specific-capacity (well pumping rate/observed drowdown) data from 265 wellperformance tests. The tested wells generally had short screens that tapped a small part of the total thickness of the aquifer. Within the screened interval, the lithology was generally consistent and could be identified.

The specific capacity of each well was converted to transmissivity for the screened interval using the nonsteady-flow equation for unconfined aquifers given by Theis (1963) and shown below:

in which

$$
T^{\prime}=\frac{Q}{S}\left(K \cdot-264 \log _{10} 5 S+264 \log _{10} t\right)
$$

$Q \quad$ is the well discharge, in gallons per minute,

$s \quad$ is the drawdown in the well, in feet,

$K$ is a factor equal to $-66-264 \log _{10}\left(3.74 r^{2} \cdot 10^{-6}\right)$,

$r$ is the radial distance to the well where the drawdown is observed, in feet,

$t \quad$ is the length of the pumping period, in days,

$S \quad$ is the aquifer specific yield (dimensionless), and

$T^{\prime}$. is a value related to transmissivity by means of an equation given by Theis (1963, p. 332, equation 2), in gallons per day per foot. 
The value of $T$ ' was converted to transmissivity, $T$, for the screened interval of the well by solving the relationship between $T$ and $T$ ' presented by Theis:

$$
T^{\prime}=T-\left(264 Q \log 10\left(T \cdot 10^{-5}\right)\right) / \mathrm{s}
$$

The value of transmissivity for the screened interval was divided by the screened length of the well to obtain the average hydraulic conductivity of the screened interval.

The well-performance data and the calculated hydraulic conductivities were divided into groups according to the lithologic types reported for the screened intervals of the wells. The values within each group were averaged to obtain the estimated hydraulic conductivity for each type of material (table 1).

Table 1,--Estimates of average hydraulic conductivity for lithologic types calculated from specific-capacity data

\begin{tabular}{lcccc}
\hline \multicolumn{1}{c}{ Lithology } & $\begin{array}{c}\text { Number } \\
\text { of } \\
\text { samples }\end{array}$ & \multicolumn{2}{c}{ Hydraulic conductivity (ft/d) } \\
\cline { 3 - 4 } & $\begin{array}{c}\text { Mean } \\
\text { value }\end{array}$ & $\begin{array}{c}\text { Standard } \\
\text { deviation }\end{array}$ & $\begin{array}{c}\text { Median } \\
\text { value }\end{array}$ \\
\hline $\begin{array}{l}\text { Fine sand } \\
\text { Fine to medium sand }\end{array}$ & 34 & 450 & 310 & 440 \\
Medium sand & 51 & 450 & 280 & 400 \\
Medium to coarse sand & 14 & 500 & 450 & 310 \\
Coarse sand & 22 & 600 & 380 & 480 \\
Fine to coarse sand & 11 & 430 & 220 & 400 \\
All sand & 42 & 580 & 290 & 520 \\
Sand and gravel & 174 & 500 & 310 & 400 \\
Fine sand and gravel & 16 & 630 & 430 & 420 \\
Medium sand and gravel & 48 & 530 & 370 & 420 \\
Coarse sand and gravel & 9 & 740 & 460 & 730 \\
All sand and gravel & 18 & 630 & 430 & 420 \\
\hline
\end{tabular}

Because of the large deviation of values about the calculated means and because most of the available lithologic information did not have the same level of detail as shown in table 1 , the sediment-type cotegories were grouped into larger classes, and average values were applied to each class (table 2).

Table 2.-Average hydraulic conductivity values for grouped lithologic types

\begin{tabular}{lr}
\hline Lithology & $\begin{array}{c}\text { Hydraulic } \\
\text { conductivity } \\
\text { (ft/d) }\end{array}$ \\
\hline Silt and (or) clay & 1 \\
Sand & 450 \\
Sand and gravel & 500 \\
Gravel & 600 \\
\hline
\end{tabular}

None of the wells were screened in silt, clay, or gravel only. The hydraulic conductivity of silt and clay is low relative to the other materials; therefore, a value of $1 \mathrm{ft} / \mathrm{d}$ was assigned. Gravel was assigned a hydraulic conductivity of $600 \mathrm{ft} / \mathrm{d}$. 
These values of hydraulic conductivity were applied by means of equation 1 to numerous locations on Cape Cod for which a lithologic log "was available to determine transmissivities of selected zones of the aquifer. These zones correspond to different layers of the flow models and will be discussed in a later section.

$\because$ During the process of estimating hydraulic conductivity from specific-capacity data, it was assumed that the storage coefficient was 0.2 ; well entrance losses were negligible; flow into the well was horizontal, radial, and uniform along the well screen; and the discharge was sustained by withdrawal from aquifer storage within the screened interval. Flow.rates in these tests were generally low, and well-entrance losses were probably minimal. Errors generated by deviation from the remaining assumptions and by incorrect estimotion of storage coefficient were assumed to be random and, therefore, would be minimized in the averaging process. These estimates of hydraulic conductivity may contain a small systematic error. The vertical span of, the flow pattern toward the well screen would always exceed the screened interval of the well. This would cause the calculated values to be high.

The specific-capocity data and the lithologic information utilized in the hydraulic conductivity calculation were obtained from drillers' records. The method of specific-capacity testing varied from one driller to another, and the identification of lithologic type is somewhat subjective. The data, therefore, were of variable quality. The error due to the variable quality of the data probably is random and would be minimized in the averaging process.

\section{Aquifer, Test Analyses, ...:}

Lateral hydraulic conductivity, the ratio between lateral and vertical hydraulic conductivity, and storage properties of the aquifer were also estimated from analysis of three aquifer tests. A 72-hour test in Truro, Massachusetts, on a well with a 70-foot. screened interval (Guswa and Londquist, 1976) was used to estimate that the overage lateral hydraulic conductivity for a predominantly very fine to coarse sand is approximately $220 \mathrm{ft} / \mathrm{d}$. Analysis of 5-day tests in Orleans and Yarmouth, Massachusetts, indicated a lateral hydraulic conductivity of approximately $300 \mathrm{ft} / \mathrm{d}$ for a coarse to very coarse sand and very fine gravel with some medium sand, and $200 \mathrm{ft} / \mathrm{d}$ for a fine to medium sand.

Analysis of the Truro and Orleans aquifer-test data using a radial-flow model yielded a ratio of lateral to vertical hydraulic conductivity of less than 10:1. As no other field data were available, and as other studies (Getzen, 1977, p. 10; Meyer and others, 1975, p. 19) have indicated that this ratio is reasonable for glacial outwash material, the 10:1 ratio was applied to each lithologic type.

There are no reliable dato available for the vertical hydraulic conductivity of the silt and clay lenses which are scattered throughout the Cape Cod aquifer system. A value of $0.1 \mathrm{ft} / \mathrm{d}$, which is similar to that used in the analog-model analyses of ground-water flow on Long Island (Getzen, 1977) was used for these beds.

Field data for storage coefficients of the Cape Cod aquifer system are also meager. Palmer (1977, p. 45) reports a range of specific yield of 0.13 to 0.26 . His values were based on analysis of aquifer tests in the Falmouth area. Analysis of the Truro (Guswa and Londquist, 1976) and Orleans aquifer-test data indicate a specific yield of between 0.10 and 0.15 .

\section{Hydrologic System}

The Cape Cod aquifer system is the freshwater-saturated sediments through which water moves. The boundaries of this system are the water table, the saline surface-water boundaries, and either the bedrock surface (or other material of low hydraulic conductivity) or a boundary between fresh ground water and saline ground water.

The saline surface-water boundaries include the ocean, bays, streams, and marshes which are generally at a fixed elevation and serve as discharge boundaries for the ground-water-flow system. At several locations, these discharge boundaries extend sufficiently far inland to effectively subdivide the aquifer system into several nearly independent individual aquifers (fig. 2). Under existing hydrologic conditions, there is no flow between adjacent aquifers across the boundaries. Conditions of severe hydrologic stress may change the nature of these boundaries and cause water to flow between the individual aquifers. 
Bedrock has a low hydraulic conductivity compared to the sand and gravel deposits that form the Cape and can be considered to be a no-flow boundary that is the bottom of the aquifer system. In some areas, particularly in Harwich and the southern portions of Dennis and Yarmouth, thick accumulations of silt and clay underlie the sand and gravel aquifer and overlie the bedrock (D. R. LeBlanc and J. H. Guswa, written commun., 1979). These sediments also have a low hydraulic conductivity and, where they directly overlie bedrock, their upper surface is considered to be the bottom of the aquifer system.

Fresh ground water is bounded by saline surface water at the shores of the ocean, Nantucket Sound, Buzzards Bay, Cape Cod Canal, and Cape Cod Bay (fig. I) and by saline ground woter at depth. Fresh ground water is slightly less dense than saline water and, therefore, "floats" as a lens-shaped body upon underlying saline water in the ground-water reservoir. The boundary between freshwater and saline water is a zone of mixing (or diffusion) of fresh and saline water. This mixing zone is the lower boundary of the aquifer system in those areas where it is above the bedrock surface or the thick silt and clay layers.

\section{DIGITAL-SIMULATION MODEL}

The purpose of the simulation model is to calculate the hydraulic head in an aquifer at specified locations under steady-flow conditions. This is achieved by solving the steady-state differential equation of ground-water flow, which requires that the hydraulic properties, boundaries, and inflow and outflow be defined for the modeled area.

A three-dimensional steady-state-flow model was chosen for this study because:

(1) Existing hydrogeologic information and a previous study (Burns and others, 1975) indicated that the three-dimensional variability of the aquifer system had to be included in the analyses,

(2) there were not sufficient long-term records of head and stress changes which could be used to calibrate a three-dimensional transient model, and

(3) the approximation used to represent the boundary between fresh and saline ground water is valid only for equilibrium conditions.

\section{Flow Equation} medium is:

The differential equation describing three-dimensional steady-state flow in a porous

$$
\frac{\partial}{\partial x}\left(K_{x x} \frac{\partial h}{\partial x}\right)+\frac{\partial}{\partial y}\left(K_{y y} \frac{\partial h}{\partial y}\right)+\frac{\partial}{\partial z}\left(K_{z z} \frac{\partial h}{\partial z}\right)=W(x, y, z)
$$

in which

$$
K_{x x}, K_{y y}, K_{z z}
$$

h

$W(x, y, z)$ are the principal components of the hydraulic-conductivity tensor alined with the principal Cartesian coordinate axes $(L / T)$,

is the hydraulic head (L), and

is a volumetric flux per unit volume $(1 / T)$ and is referred to as a source term.

It is sometimes convenient to represent one or more hydrogeologic units as a single layer. If this is done, then equation 3 is multiplied by $b$, the saturated thickness of the layer, giving approximately:

in which

$$
\frac{\partial}{\partial x}\left(T_{x x} \frac{\partial h}{\partial x}\right)+\frac{\partial}{\partial y}\left(T_{y y} \frac{\partial h}{\partial y}\right)+b \frac{\partial}{\partial z}\left(K_{z z} \frac{\partial h}{\partial z}\right)=b W(x, y, z)
$$


The source term $W(x, y, z)$ can include well discharge; recharge from precipitation or other sources such as septic tanks, sewage-treatment plants, and irrigation; and steady leakage into or out of the aquifer system through a stream, pond, marsh or ocean bottom.

In the model, this source term is computed as:

$$
b W=\frac{Q_{w}}{\Delta x \Delta y}-Q_{r e}-\frac{k_{z}}{m}\left(h_{s}-h\right)
$$

in which

$$
\begin{aligned}
& Q_{W} \quad \text { is well discharge from a "block" or element of the aquifer }\left(L^{3} / T\right), \\
& \Delta x \quad \text { is the length of the "block" in the x-direction ( } L), \\
& \Delta y \quad \text { is the length of the "block" in the y-direction (L), } \\
& Q_{r e} \quad \text { is aquifer recharge and is the volumetric flux per unit area of the uppermost } \\
& \text { hydrogeologic unit }(L / T), \\
& K_{z} \quad \text { is the vertical hydraulic conductivity of the streambed or ocean bottom }(L / T), \\
& m \quad \text { is the thickness of the streambed or ocean bottom }(L), \\
& h_{s} \quad \text { is the hydraulic head in the streambed or ocean bottom }(L) \text {, and } \\
& h \quad \text { is the head in aquifer (L). }
\end{aligned}
$$

Direct solution of equation 4 is generally impossible, but a numerical solution of high accuracy can be obtained using a digital computer.

\section{Numerical Method}

To obtain a numerical solution, the partial differential equation is replaced by an approximating finite-difference equation (Trescott, 1975, and Trescott and Larson, 1976) and the aquifer is subdivided into discrete blocks. Each aquifer block has one finite-difference equation describing flow within it. This yields a set of finite-difference equations which must be solved simultaneously.

There are many procedures available for solving a large number of simultaneous equations. The one used in this study is the strongly implicit procedure (SIP) developed by Stone (1968). For a complete discussion of how the finite-difference equations are solved, see Trescott (1975) and Trescott and Larson (1976).

The computer code used in this study is a modification of the code developed by Trescott (1975). Input documentation and a source-code listing are included in the Supplemental Data section of this report.

\section{APPLICATION OF SIMULATION MODEL}

\section{Model Specifications}

Ground-water-flow models were developed for five areas of Cape Cod. The present flow pattern allowed construction of separate models for five of the six individual aquifers shown on figure 2. Limits of the modeled areas were selected to include or nearly coincide with the natural flow boundaries of the system. These lateral boundaries are discharge boundaries such as the seabed, streams, and marshes. They are modeled as specified-head seepage boundaries.

The modeled areas were subdivided into rectangular finite-difference grids with uniform horizontal spacing (figs. 3-7) and uneven vertical spacing. Table 3 summarizes the descriptive information for the individual finite-difference grids. 


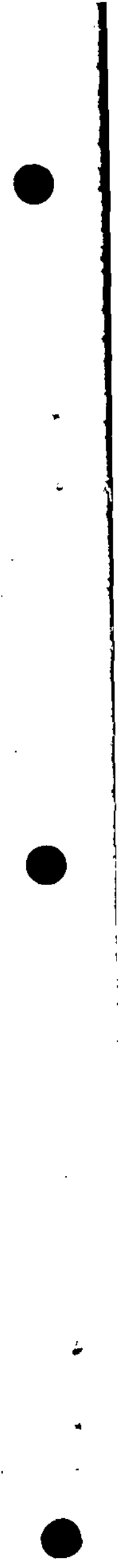




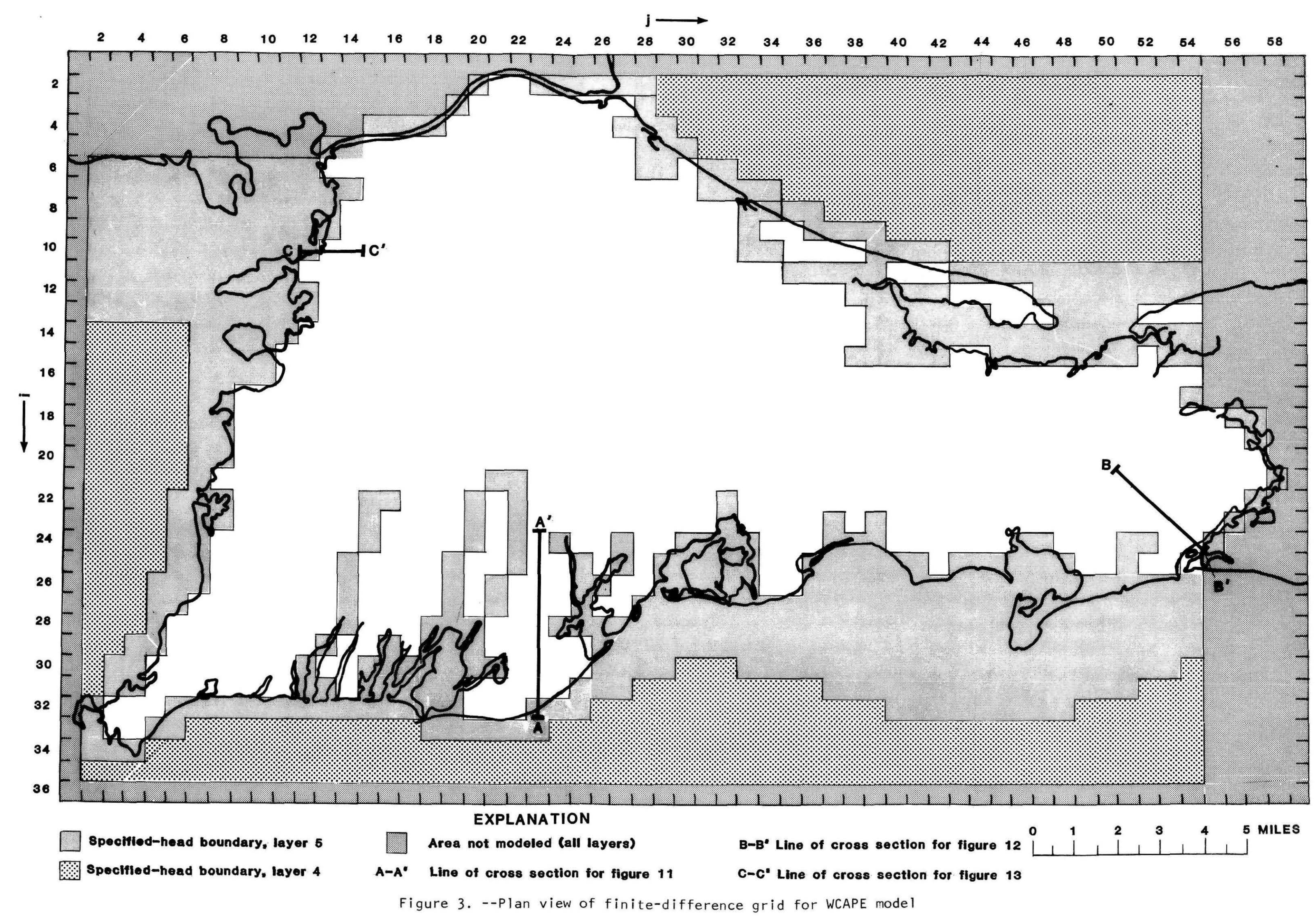




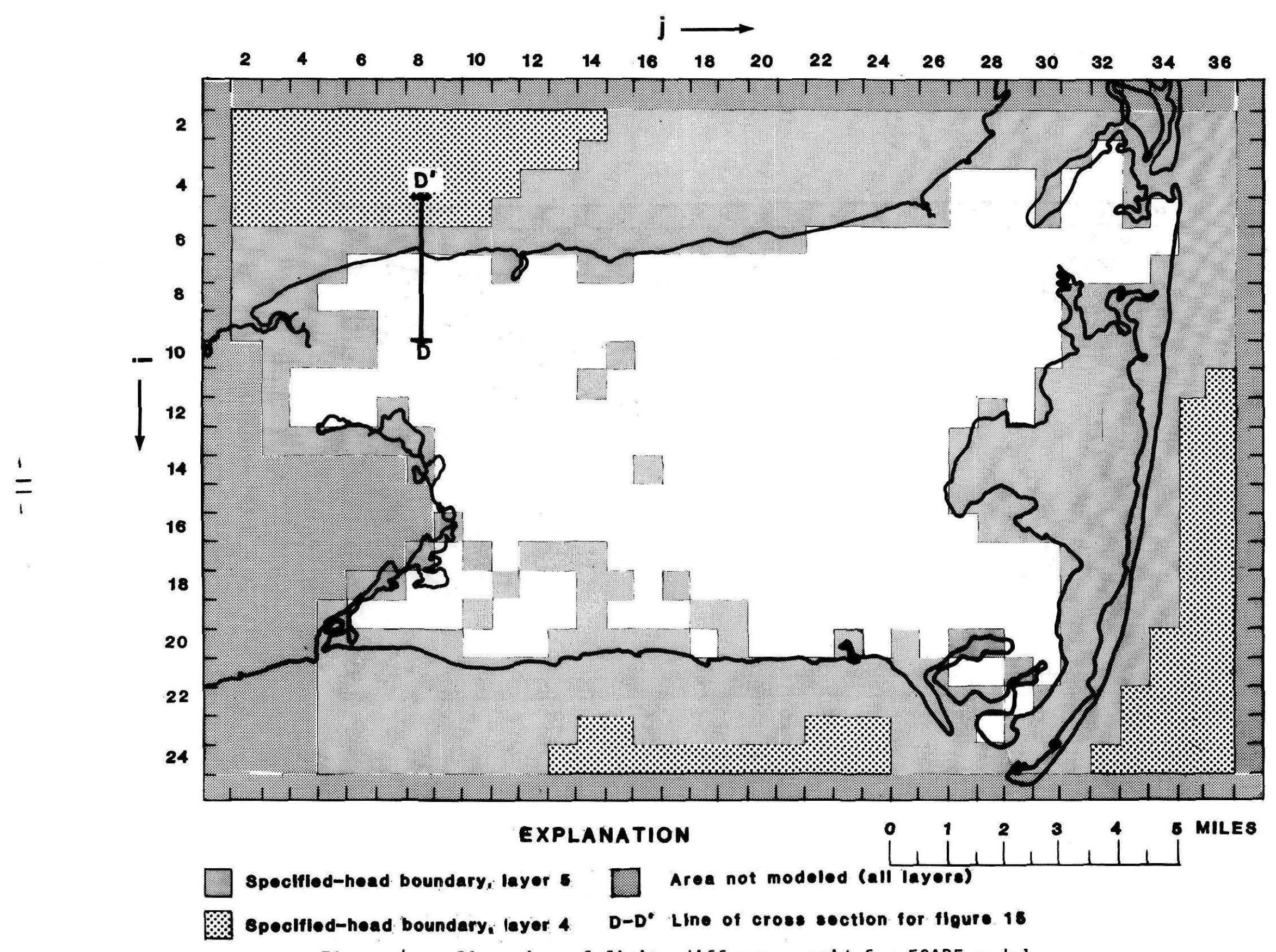

Figure 4.-- Plan view of finite-difference grid for ECAPE model 


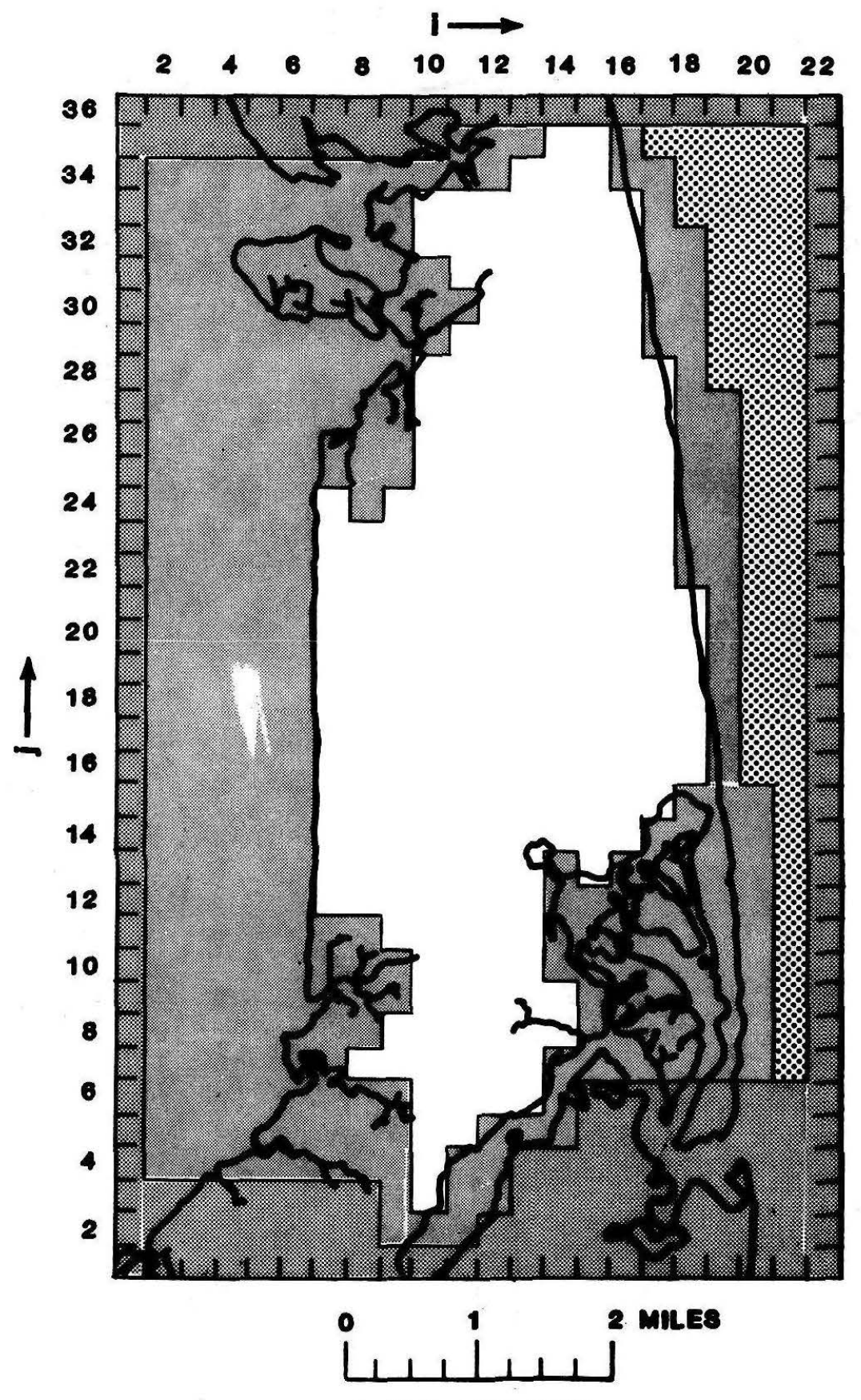

EXPLANATION

Dpectiled-head boundary, layer 7

8peclified-hoed boundary, byer 6

Area not modoled (all layore)

Figure 5.-- Plan view of finite-difference grid for ESTHM model 


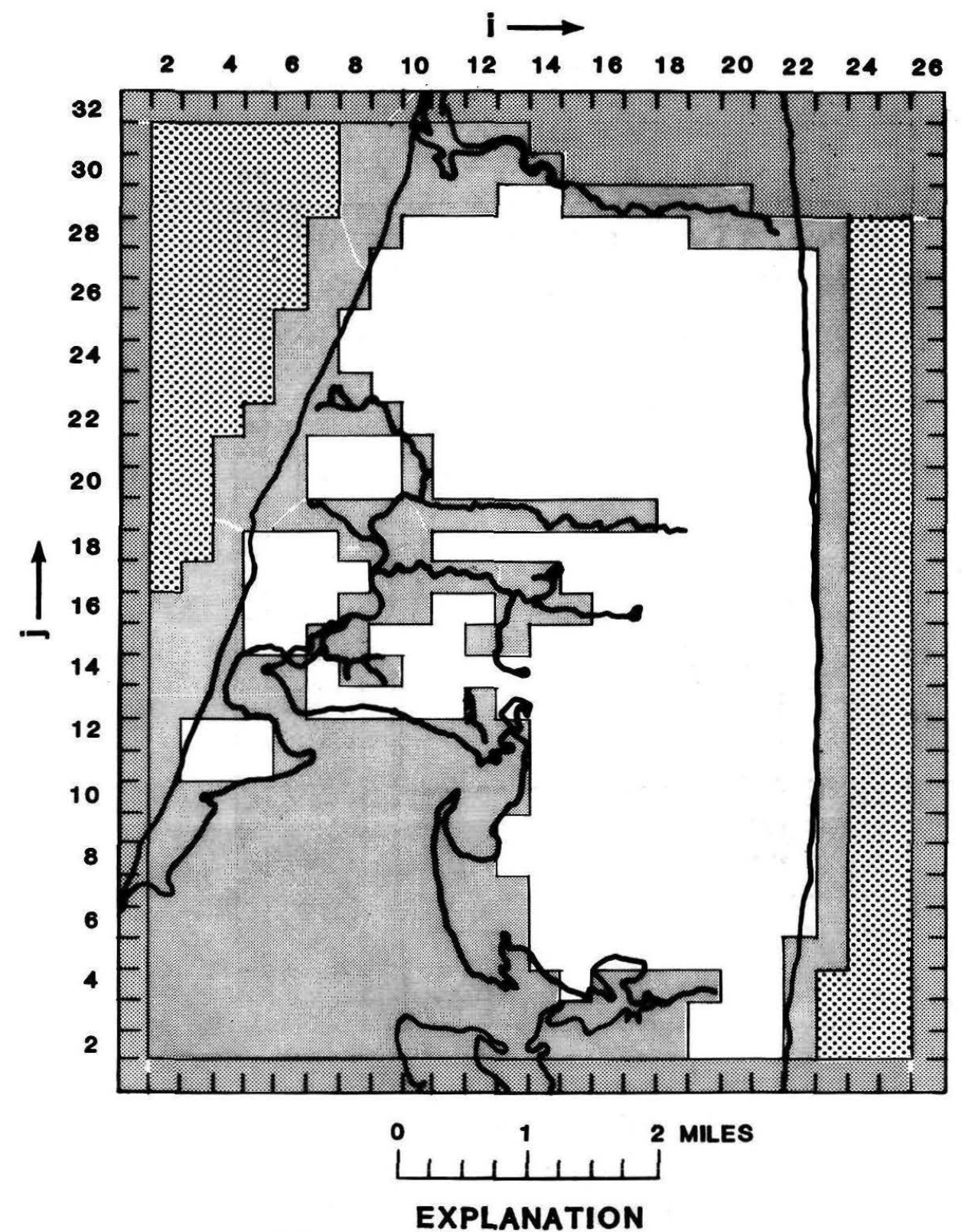

Specified-head boundary, layer 7

specified-head boundary, layer 6

Area not modeled (all layers)

Figure 6. --Plan view of finite-difference grid for WLFLT model 

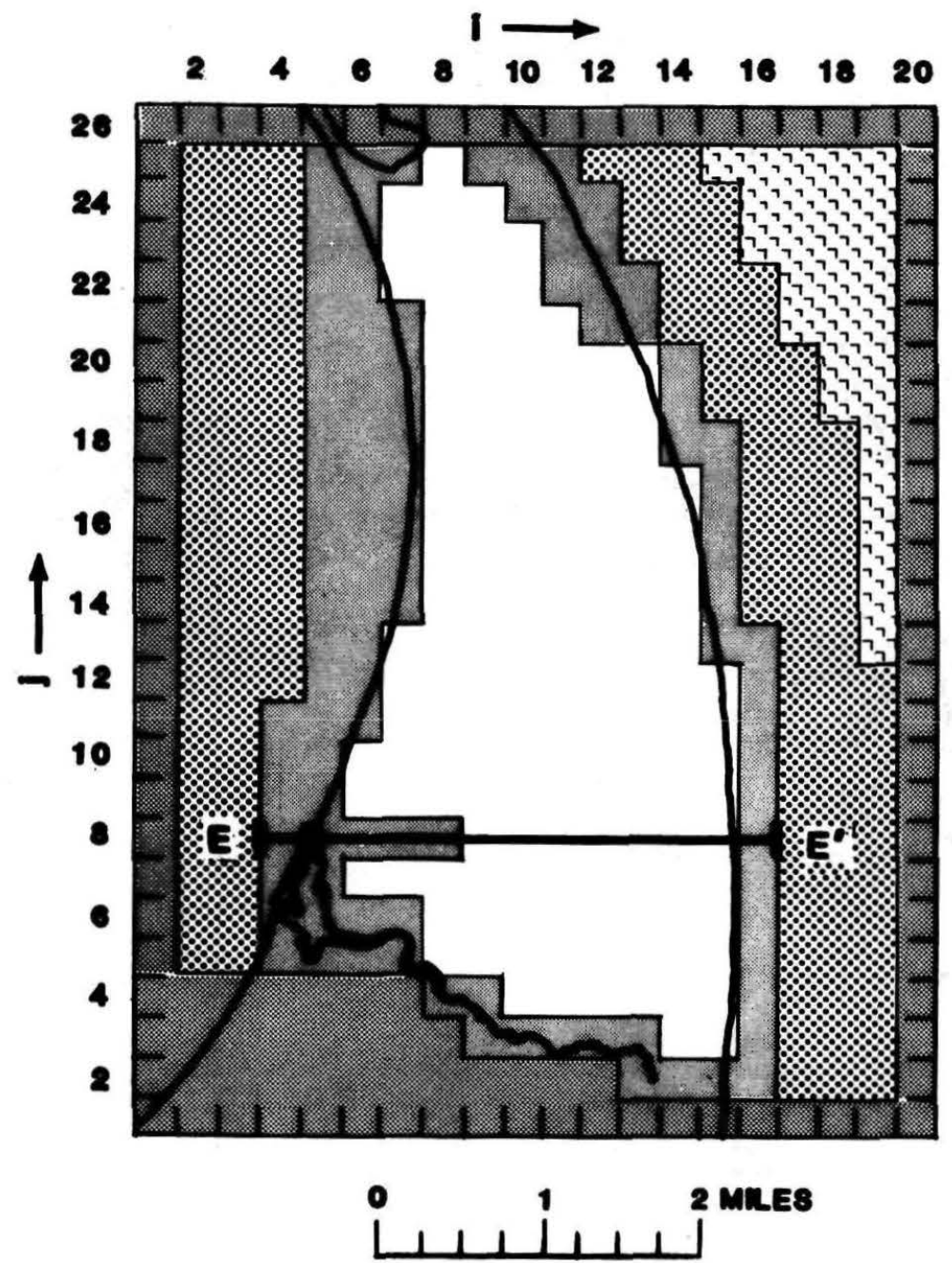

EXPLANATION

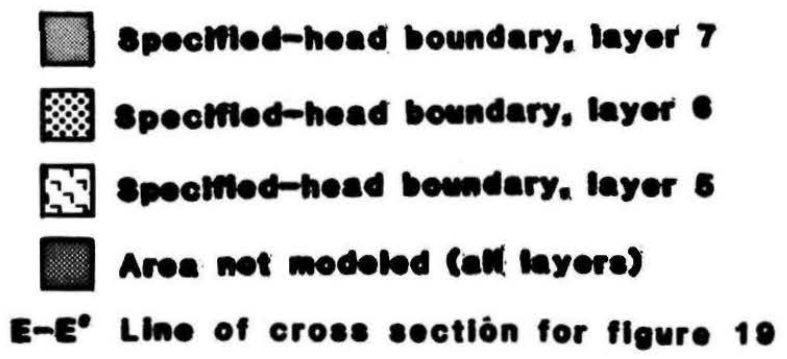

Figure 7.-- Plan view of finite-differeace grid for TRURO model 
Table 3.--Descriptive information regarding finite-difference grids for modeled areas

\begin{tabular}{|c|c|c|c|c|c|c|c|c|c|c|c|}
\hline \multirow[t]{3}{*}{$\begin{array}{l}\text { Modeled } \\
\text { area }\end{array}$} & \multirow[t]{3}{*}{ rows } & \multirow[t]{3}{*}{$\begin{array}{l}\text { col- } \\
\text { umns }\end{array}$} & \multirow[t]{3}{*}{ layers } & \multirow[t]{3}{*}{$\begin{array}{l}\text { Horizontal } \\
\text { grid } \\
\text { spacing } \\
\text { (feet) }\end{array}$} & \multicolumn{7}{|c|}{$\begin{array}{l}\text { Elevation of bottom of layer } \\
\quad \text { (feet below sea level) }\end{array}$} \\
\hline & & & & & \multicolumn{7}{|c|}{ Layer number } \\
\hline & & & & & 1 & $: 2$ & 3 & 4 & 5 & 6 & 7 \\
\hline WCAPE & 36 & 59 & 5 & 2640 & 400 & 240 & 140 & 70 & 20 & - & - \\
\hline ECAPE & 25 & 37 & 5 & 2640 & 400 & 240 & 140 & 70 & 20 & -- & -- \\
\hline ESTHM & 22 & 36 & 7 & 1320 & 600 & 450 & 300 & 200 & 110 & 50 & 10 \\
\hline WLFLT & 26 & 32 & 7 & 1320 & 400 & 280 & 200 & 140 & 80 & 40 & 10 \\
\hline TRURO & 20 & 26 & 7 & 1320 & 400 & 280 & 200 & 140 & 80 & 40 & 10 \\
\hline
\end{tabular}

The layers of each model represent elevation horizons within the aquifer system. These horizons contain one or more hydrogeologic units. Aquifer properties and stresses are assumed to be uniform within any given block and must be defined at all nodes of the grid.

By convention, nodes are located at the centers of the blocks of the grid. Any specific node or block may be referenced by citing its row $(i)$, column $(j)$ and layer $(k)$ location.

\section{Water-Transmitting Properties of the Aquifer}

At about 320 selected locations in the aquifer system, lithologic logs and the average values of hydraulic conductivity for the lithologic types in table 2 were used in equation 1 to calculate transmissivity values for layers of the model. An average, or equivalent, lateral hydraulic conductivity for each layer was also calculated using the relationship:

in which

$$
\overline{\mathrm{K}}=\frac{\sum_{i=1}^{n} \mathrm{~K}_{i} \mathrm{~m}_{i}}{\sum_{i=1}^{n} \mathrm{~m}_{i}}
$$

$\overline{\mathrm{K}} \quad$ is the average lateral hydraulic conductivity $(\mathrm{L} / \mathrm{T})$,

$\mathrm{K}_{i}$ is the average lateral hydraulic conductivity of the $i$ th hydrogeologic unit $(L / T)$,

$m_{i}$ is the thickness of the $i$ th hydrogeologic unit (L), and

$n$ is the number of hydrogeologic units which occur within a layer. The top of the uppermost layer coincides with the estimated position of the water table.

Maps of the spatial variation in transmissivity and lateral hydraulic conductivity were made for all layers and served as initial values of the water-transmitting properties of the aquifer. 
Equivalent vertical hydraulic conductivities were also calculated from lithologic logs at the 320 locations. Darcy's Law and the analogy between flow in an aquifer and flow of electric current were used to calculate these values. One-dimensional steady-state flow through an oquifer prism can be defined by the following equation:

$$
Q=K A \frac{\Delta h}{\Delta z}
$$

in which

$Q \quad$ is the rate of flow through the prism $\left(\mathrm{L}^{3} / \mathrm{T}\right)$,

$K$ is the hydraulic conductivity of the aquifer in the direction of flow $(L / T)$,

A is the cross-sectional area of the prism (L2),

$\Delta h \quad$ is the head difference between two measuring points along the flow direction (L), and

$\Delta \mathbf{z}$ is the length between the two measuring points $(L)$.

The term $\frac{K A}{\Delta Z}$ is analogous to electrical conductance (Prickett, 1975) and will be defined herein as hydraulic conductance, $C$. In a manner similar to calculating the equivalent electrical conductance when two or more conductors are connected in series, the equivalent vertical hydraulic conductance of a layered aquifer can be calculated using the relationship:

$$
\frac{1}{c_{v_{\text {eq }}}}=\sum_{i=1}^{n} \frac{1}{c_{v_{i}}}
$$

in which

$C_{v_{e q}}$ is the equivalent vertical hydraulic conductance of an aquifer $(L 2 / T)$,

$\mathrm{C}_{\mathrm{Vi}}$ is the vertical hydraulic conductance of the $i$ th layer $\left(L^{2} / T\right)$, and

$n \quad$ is the number of layers of the aquifer.

As an example, figure 8 shows an aquifer that contains two layers.

Making the appropriate substitutions, equation 8 con be rewritten as:

in which

$$
\frac{\frac{1}{\mathrm{~K}_{\mathrm{v}_{\mathrm{eq}}} \cdot \mathrm{A}}}{\Delta \mathrm{z}_{\mathrm{T}}}=\sum_{i=1}^{n} \frac{\frac{1}{\mathrm{~K}_{\mathrm{v}^{\cdot A}}}}{\Delta \mathrm{z}_{i}}
$$

$K_{v_{e q}}$ is the equivalent vertical hydraulic conductivity $(L / T)$,

A is the cross-sectional area of flow $\left(\mathrm{L}^{2}\right)$,

$\Delta z_{T} \quad$ is the total thickness of the aquifer and is equal to $\sum_{i=1}^{n} \Delta z_{i}(L)$,

$K_{v_{i}}$ is the vertical hydraulic conductivity of the $i$ th layer $(L / T)$, and

$\Delta z i \quad$ is the thickness of the $i$ th layer (L). 

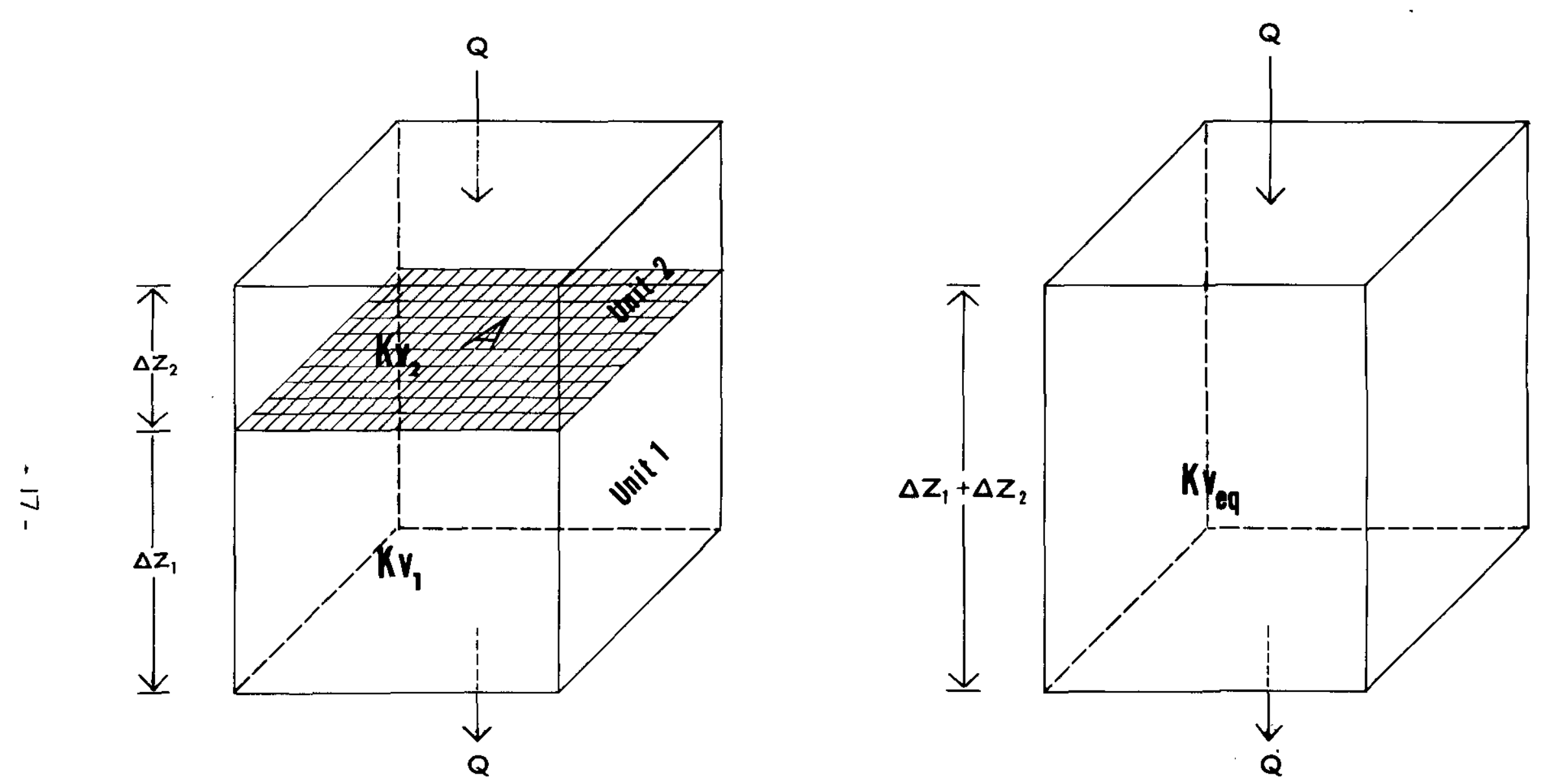

Figure 8.-- Schematic representation of equivalent vertical hydraulic conductivity 
Multiplying both sides of equation 9 by the constant $A$ and rearranging terms yields:

$$
\mathrm{K}_{\mathrm{veq}}=\Delta \mathrm{z}_{\mathrm{T}} \frac{1}{\sum_{i=1}^{n} \Delta \mathrm{z}_{i} / \mathrm{k}_{\mathrm{v} i}}
$$

which also can be written as:

$$
\mathrm{k}_{\mathrm{veq}}=\frac{\sum_{i=1}^{n} \Delta z_{i}}{\sum_{i=1}^{n} \Delta z_{i} / \mathrm{k}_{\mathrm{v}_{i}}}
$$

Equivalent vertical hydraulic conductivity values for selected nodes were compared to the estimated lateral hydraulic conductivity values to determine a ratio between lateral and vertical hydraulic conductivity.

Using the lateral transmissivity, hydraulic conductivity, estimated ratio between lateral and vertical hydraulic conductivity, and thickness of each block, vertical flow coefficients (Trescott and Larson, 1976, p. X) were calculated.

During model calibration, it was necessary to adjust the initial estimates of transmissivity and lateral and vertical hydraulic conductivity. The final values used in the models are presented in the Supplemental Data section of this report.

\section{Boundaries and Hydraulic Stresses}

\section{Well Discharge}

Sites of known and significant well discharge within the study area were represented in the model by specifying a constant flux rate at the nodes representing the blocks which contain the wells. Well discharges are summarized in the Supplemental Data section of this report. These average withdrawal rates are based on actual pumpage for the years 1975 and 1976. The pumpage information was provided by the local water-service districts.

\section{Boundary Between Fresh and Saline Water}

The saline surface water which surrounds Cape Cod forms a surface boundary to the ground-water reservoir. The seabed is a specified-head boundary to the ground-water-flow system. The distribution of freshwater head along this boundary is a function of the saline-water depth and the density difference between freshwater and saline water. At the bottoms of the bays and the ocean, freshwater heads at the seabed-water interface must be equal to the equivalent freshwater head resulting from the saline surface-water column extending from the seabed to sea level. If the surface-water body is seawater, the resulting equivalent freshwater head above sea level is about 2.5 percent of the saline surface-water depth. It is proportionately less if the density of the surface-water body is less than the density of seawater. This equality of freshwater and saline-water head at the seabed must also exist at the boundary between fresh ground water and saline ground water if the boundary is a sharp interface, the saline ground water is static (nonflowing), dynamic equilibrium is to be maintained, and the only forces acting on the ground water are head gradients arising from gravitational forces (Hubbert, 1940). Figure 9 illustrates this relationship between fresh ground water and saline surface and ground water. 


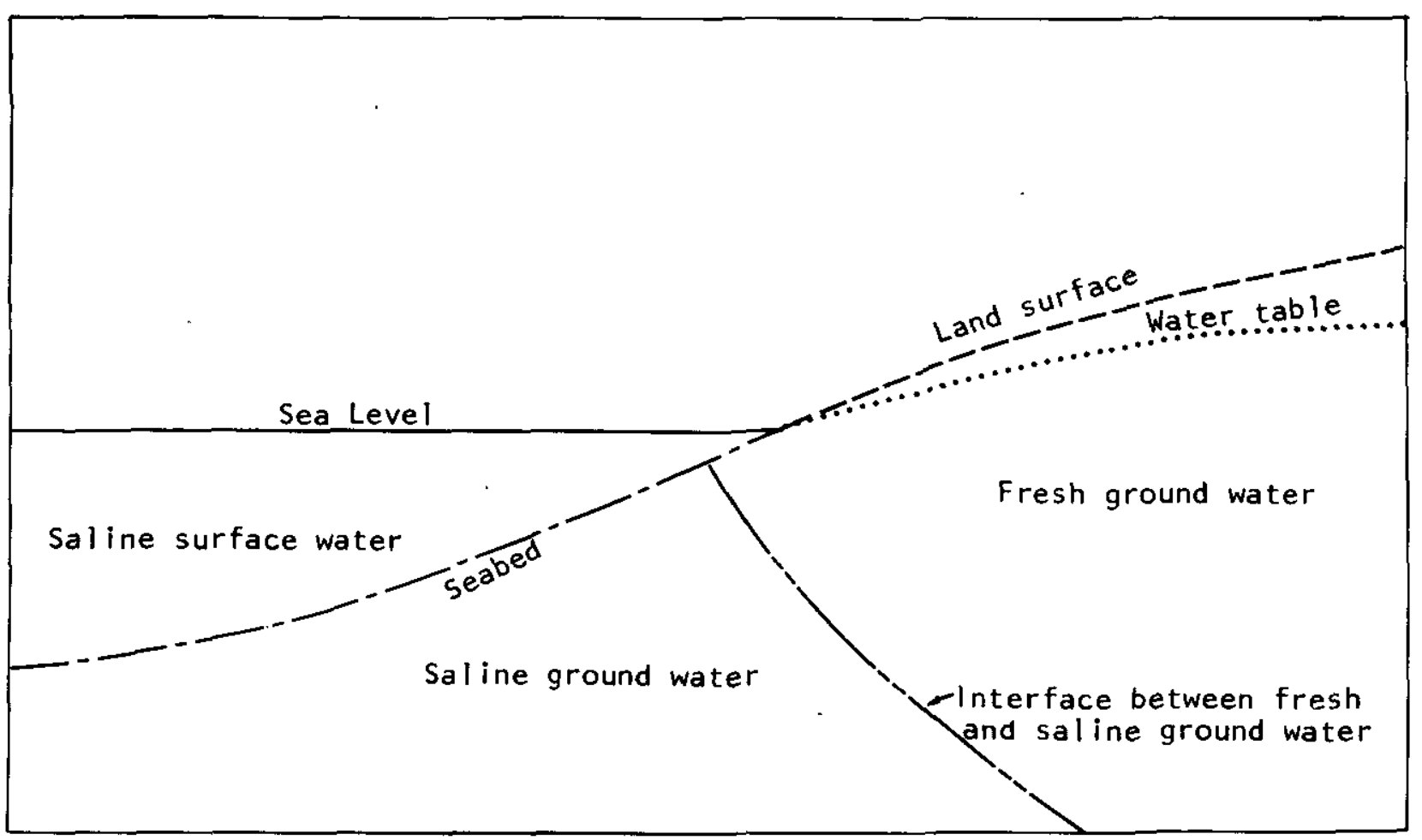

Figure 9.--Schematic hydrologic section of the seaward boundary of fresh ground-water flow. Along the seabed, freshwater heads must be equal to the equivalent freshwater head resulting from the saline surface water column extending from sea level to the seabed. Along the interface, freshwater head balances saline water head in the aquifer. 
The seabed was modeled as a specified-head seepage boundary. The layers for which this boundary condition was specified were determined by comparing model layer elevations to the seabed elevation determined from bathymetric and topographic maps. The seabed elevation was specified as the source-bed bottom elevation. The equivalent freshwater head resulting from the density difference between freshwater and seawater was specified as the source-bed head. A leakance coefficient of $20(\mathrm{ft} / \mathrm{d}) / \mathrm{ft}$ was used. Sensitivity analyses indicate that changing this value by an order of magnitude has no significant effect on the calculated heads or flux rates. Provided sufficient precision is used in mass balance calculations, this is an acceptable way of approximating a constant-head condition (Trescott and others, 1976). Data on the spatial variability of vertical permeability and thickness of the seabed sediments can be easily incorporated into the models if they become available.

The boundary between fresh and saline ground water was modeled as an interface, and the saline-water zone was assumed to be static. This boundary is actually a zone of diffusion or mixing, but data collected concerning the thickness of this zone (LeBlanc and Guswa, written commun., 1979) suggest that it is narrow, and for the purposes of this study it can be treated as a sharp interface.

At specified iterations, the models calculate the position of this interface in accordance with the hydrodynamic model of Hubbert (1940). Starting with the bottom layer and proceeding through the grid in a systematic fashion, block transmissivity values are adjusted to reflect the percentage of the block thickness which is occupied by freshwater. For example, the transmissivity of a block in which only the upper 40 percent of the thickness contains freshwater is reduced to 40 percent of its original value. A block calculated to be wholly in the saline-water zone is assigned a transmissivity value of zero for the rest of the simulation. If a block contains partially or totally freshwater, then all blocks vertically above it are assumed to contain only freshwater. The vertical flow coefficients remain unchanged during a simulation unless the freshwater-saturated thickness of a block is determined to be zero. When this occurs, the coefficient describing flow between the block with zero freshwater thickness and the overlying block is set to zero. An identical adjustment for water-table conditions is described in Trescott and Larson (1976, p. XII).

The computational scheme requires that the starting head values be sufficiently large to define an interface position which is seaward of and deeper than the real interface position. During the iteration sequence, the calculated interface moves landward and upward until it is in balance with the freshwater-flow system.

\section{Streams and Marshes}

Many of the streams and marshes are significant boundaries to the freshwater-flow system. Their effect varies as a function of the head within the aquifer. They generally derive some or all of their flow from ground-water discharge or seepage, and at certain locations or times of the year may be a source of aquifer recharge. These boundaries were modeled as areas of specified head, separated from the aquifer by a streambed layer. The source-bed bottom elevation was defined to coincide with the altitude of the stream or marsh bottom, the source-bed head was set equal to the altitude of the stream or marsh surface, and a leakance coefficient of $20(\mathrm{ft} / \mathrm{d}) / \mathrm{ft}$ was used. This value might represent a 2 -foot-thick sand layer.

\section{Aquifer Recharge}

Aquifer recharge is a combination of natural recharge from precipitation and artificial recharge from sources such as septic tanks and wastewater-treatment plants. LeBlanc and Guswa (written commun., 1979), using the Thornthwaite method (Thornthwaite and Mather, 1957), estimated the evapotranspiration for several locations on Cape Cod. This is an empirical determination and is based on analysis of climatological data. U.S. Weather Bureau data for 1947 to 1976 were used in the analysis. The calculated average evapotranspiration rate and the average precipitation rate for the same period were used to estimate an average rate of natural recharge. The rates obtained compare favorably with estimates of average natural recharge on Cape Cod made by Strahler (1972) and Palmer (1977). For each node in the top layer, this value was added to the estimated artificial recharge rate, where applicable, to obtain an average total recharge rate. 
Estimated rates of artificial recharge were based on the assumption that artificial recharge occurs in those areas where the water disposal site is not in the same model block as the source of water supply. For example, the disposal lagoons of a wastewater-treatment plant and residential areas serviced by public water supply and onsite disposal systems were treated as areas of artificial recharge. No net artificial recharge or discharge was simulated in areas serviced by shallow domestic wells and onsite disposal systems.

The estimated artificial recharge rate was calculated on a town-by-town basis by making the assumptions that:

(1) Those areas identified in the draft Cape Cod 208 Water Quality Management Plan (U.S. Environmental Protection Agency, 1978) as wastewater-management problem areas (U.S. Environmental Protection Agency, 1978, map 4.1) are areas of artificial recharge because they represent areas of high concentration of septic tanks and are serviced by public water supply, and

(2) the rate of artificial recharge is uniform within these areas and proportional to the difference between the rate of withdrowal by the public water-supply system and any wastewater-treatment plant flow rates.

Another factor which influences the rates of aquifer recharge is the thickness of the unsaturated zone. Where the water table is close to land surface, more of the water that infiltrates the soil may be transpired by plants or evaporated. Consequently, a smaller portion of rainfall becomes a net addition to the ground-water reservoir in low-lying swampy areas than in areas with a thicker unsaturated zone. To approximate this effect for the WCAPE and ECAPE models, the calculated aquifer recharge was reduced proportionally (approximately 10 percent) in low-lying areas near the coast. The finer grid spacing of the ESTHM, WLFLT, and TRURO models allowed a closer approximation of the position of the streams and wetlands where the water table is close to land surface. These natural discharge areas were modeled as constant head zones. Consequently, net recharge rates did not have to be reduced.

Final recharge distributions used are presented in the Supplemental Data section of this report.

\section{CALIBRATION OF THE STEADY-STATE FLOW MODELS}

\section{Purpose and Procedure}

An important objective of calibrating the steady-state model is to improve the conceptual model of the aquifer. The conceptual model consists of an understanding of the physical and functional nature of the aquifer. This includes identifying sources of recharge and discharge, rates and direction of flow, variation of aquifer properties and hydraulic head, and the relation of the aquifer to surface water. The simulation model numerically integrates the effects of these factors. The computed results, therefore, are internally consistent with all input data, and one can determine if any element of the conceptual model must be revised. After initial best-estimates of the input data are made, model development is an evolutionary process in which results of previous simulations are interpreted to make modifications and adjustments to the model. The testing process of adjusting input data and comparing the calculated results to field observations (calibration) allows for a better understanding of the flow system and an improvement of the conceptual model.

To demonstrate that the flow models are reasonable, field observations must be closely correlated with model results. Field observations available for the Cape Cod aquifer system include observed water levels, position of the interface between fresh and saline ground water, and discharge measurements for selected stream segments. Based on records of water levels at selected long-term and short-term observation sites, LeBlanc and Guswa (written commun., 1979) prepared a map which shows the estimated average water table for the period from 1963 to 1976 and shows the interface position at several locations. 
The calibration procedure minimizes differences between the observed and computed values by adjusting the input data (aquifer properties, boundary conditions, and hydraulic stresses). Because of the large number of interrelated factors affecting ground-water flow, this is a subjective procedure. The degree of allowable adjustment, however, of any parameter generally is directly related to the uncertainty of its value or specification. For example, withdrawal rates are well defined, and their values were not adjusted. Hydraulic conductivity and transmissivity, however, are generally imprecisely known because lithologic variation is usually not well defined and because the methods by which they are determined are subject to many limitations. During the calibration, these values were adjusted by as much as 20 percent for those areas where the variation of lithology was believed to be gradual. These areas generally, but not always, coincided with the outwash plains. For those areas of known extreme lithologic variation, particularly the moraine areas, the transmissivity and hydraulic conductivity values were adjusted by as much as a factor of ten.

Because the calibrated model is based on an interpretation of field observations, the accuracy of the model results is restricted by the accuracy of the interpretation. The water-table configuration and position of the interface between fresh and saline ground water are based on limited data. Approximately 150 sites for observation of water-table elevation; 27 sites for observation of head variation, chloride concentration, and specific conductance of ground water with depth; and two stream segment discharge measurements were used as control points for calibration of the models. If any major corrections, revisions, or additions are made to the data base, the models should be recalibrated to reflect a better knowledge of the aquifer system.

\section{Results \\ WCAPE Model}

For the WCAPE model the agreement between the observed average water levels and the calculated water levels under steady state conditions is shown in table 4 and on figure 10. Some of the disagreement, particularly in the higher elevations of the water table, is due to a lack of water-level and transmissivity information in the moraine area. Another reason for disagreement is that the observed average water level refers to the observation well location and the calculated water level refers to the center of the block which contains the well. Therefore, the discrepancy between the calculated and observed water levels is greatest where the hydraulic gradient is steep. This is common to all five models.

Figures 11 to 13 show calculated altitudes of the interface between fresh and saline ground water for selected cross sections (fig. 3). Measured chloride concentrations and a resistivity log of a test hole drilled in Mashpee are also included on figure II. The resistivity measurement corresponding to the depth from which the lowermost sample in figure II (a) was taken is approximately $750 \mathrm{ohm}$-meters. This is interpreted as being within the transition zone between fresh and saline ground water. On figure II(b), the nearly vertical resistivity line from approximately -310 feet to -400 feet represents a chloride concentration which is equal to or greater than $15,000 \mathrm{mg} / \mathrm{L}$. This is interpreted as representing the saline ground-water zone.

Evaluation of model accuracy in simulating discharge to surface-water bodies was hindered by the lack of streamflow data. Stream discharges for two river segments in Falmouth were measured when streamflow on the Cape was about gverage and represented ground-water discharge. The measured discharges were 13 and $19 \mathrm{ft} 3 / \mathrm{s}$, and the calculated discharges to the nodes chosen to represent these stream segments were 9 and $20 \mathrm{ft} / \mathrm{s}$. Collection of additional streamflow data will help improve the model and provide a better data base for future calibration.

A mass balance was calculated during each simulation. As part of these calculations, a hydrologic budget for the aquifer is computed and tabulated. The hydrologic budget provides a measure of the importance of each element of the budget. For the WCAPE model, the steady-state-recharge rate is $267 \mathrm{ft}^{3} / \mathrm{s}$, the rate of withdrawal by wells is $17 \mathrm{ft} / \mathrm{s}$, and discharge to the streams, marshes and ocean is $250 \mathrm{ft} 3 / \mathrm{s}$. 
Table 4.-Comparison of calculated nodal head values and observed average water levels for the period 1963 to 1976 for selected wells, WCAPE model

\begin{tabular}{|c|c|c|c|c|c|c|c|}
\hline \multirow[t]{2}{*}{$\begin{array}{l}\text { Node } \\
(i, j, k)\end{array}$} & \multirow{2}{*}{$\begin{array}{l}\text { U.S. } \\
\text { Geological } \\
\text { Survey } \\
\text { well }\end{array}$} & \multicolumn{2}{|c|}{$\begin{array}{c}\text { Water level, in feet } \\
\text { above sea leve! }\end{array}$} & \multirow[t]{2}{*}{$\begin{array}{l}\text { Node } \\
(i, j, k)\end{array}$} & \multirow{2}{*}{$\begin{array}{l}\text { U.S. } \\
\text { Geological } \\
\text { Survey } \\
\text { well }\end{array}$} & \multicolumn{2}{|c|}{$\begin{array}{c}\text { Water level, in feet } \\
\text { above sea level }\end{array}$} \\
\hline & & $\begin{array}{l}\text { observed } \\
\text { average }\end{array}$ & $\begin{array}{l}\text { calculated } \\
\text { at center } \\
\text { of grid } \\
\text { block }\end{array}$ & & & $\begin{array}{l}\text { observed } \\
\text { average }\end{array}$ & $\begin{array}{l}\text { calculated } \\
\text { of center } \\
\text { of grid } \\
\text { block }\end{array}$ \\
\hline $\begin{array}{r}5,24,5 \\
7,14,5 \\
8,17,5 \\
9,15,5 \\
9,35,5 \\
12,14,5\end{array}$ & $\begin{array}{l}\text { SDW } 263 \\
\text { BHW } 62 \\
\text { BHW } 215 \\
\text { BHW } 211 \\
\text { SDW } 252 \\
\text { BHW } 198\end{array}$ & $\begin{array}{r}36.7 \\
7.2 \\
46.0 \\
27.3 \\
6.3 \\
22.0\end{array}$ & $\begin{array}{r}39.5 \\
3.1 \\
36.2 \\
23.8 \\
5.3 \\
29.0\end{array}$ & $\begin{array}{l}20,56,5 \\
21,14,5 \\
21,15,5 \\
21,17,5 \\
21,29,5 \\
21,31,5\end{array}$ & $\begin{array}{l}\text { YAW } 111 \\
\text { FSP } 4 \\
\text { FSP } 4 \\
\text { FSW } 167 \\
\text { AIW } 60 \\
\text { AIW } 264\end{array}$ & $\begin{array}{l}7.5 \\
34.9 \\
34.9 \\
41.3 \\
35.3 \\
26.4\end{array}$ & $\begin{array}{r}5.0 \\
33.3 \\
35.6 \\
40.8 \\
34.2 \\
27.7\end{array}$ \\
\hline $\begin{array}{l}13,28,5 \\
13,28,5 \\
14,19,5 \\
14,22,5 \\
15,22,5 \\
15,29,5\end{array}$ & $\begin{array}{l}\text { SDW } 33 \\
\text { SDW } 256 \\
\text { BHW } 27 \\
\text { SDP } 4 \\
\text { SDP } 4 \\
\text { SDW } 253\end{array}$ & $\begin{array}{l}64.0 \\
64.3 \\
66.0 \\
69.0 \\
69.0 \\
61.4\end{array}$ & $\begin{array}{l}63.0 \\
63.0 \\
64.5 \\
72.1 \\
69.8 \\
61.2\end{array}$ & $\begin{array}{l}21,36,5 \\
21,45,5 \\
21,46,5 \\
21,46,5 \\
21,52,5 \\
22,15,5\end{array}$ & $\begin{array}{l}\text { AIW } 183 \\
\text { AIW } 301 \\
\text { AIW } 302 \\
\text { AIW } 300 \\
\text { YAW } 89 \\
\text { FSW } 169\end{array}$ & $\begin{array}{l}13.2 \\
26.6 \\
19.7 \\
24.3 \\
18.0 \\
32.6\end{array}$ & $\begin{array}{l}19.2 \\
22.5 \\
19.1 \\
19.1 \\
11.3 \\
32.0\end{array}$ \\
\hline $\begin{array}{l}15,36,5 \\
16,32,5 \\
16,42,5 \\
17,21,5 \\
17,44,5 \\
17,46,5\end{array}$ & $\begin{array}{l}\text { AIW } 315 \\
\text { AIW } 29 ! \\
\text { AIW } 294 \\
\text { SDW } 154 \\
\text { AIW } 295 \\
\text { AIW } 247\end{array}$ & $\begin{array}{l}32.5 \\
50.4 \\
18.1 \\
62.6 \\
26.7 \\
20.3\end{array}$ & $\begin{array}{l}29.5 \\
52.7 \\
16.4 \\
63.1 \\
22.2 \\
19.0\end{array}$ & $\begin{array}{l}22,29,5 \\
22,35,5 \\
22,41,5 \\
22,46,5 \\
22,51,5 \\
23,17,5\end{array}$ & $\begin{array}{l}\text { AIW } 298 \\
\text { AIW } 255 \\
\text { AIW } 306 \\
\text { AIW } 230 \\
\text { YAW } 104 \\
\text { FSW I } 68\end{array}$ & $\begin{array}{l}24.3 \\
17.0 \\
27.2 \\
18.4 \\
16.6 \\
35.7\end{array}$ & $\begin{array}{l}26.8 \\
14.9 \\
19.0 \\
13.0 \\
11.4 \\
32.4\end{array}$ \\
\hline $\begin{array}{l}17,50,5 \\
17,53,5 \\
18,12,5 \\
18,26,5 \\
18,34,5 \\
18,55,5\end{array}$ & $\begin{array}{l}\text { YAW } 98 \\
\text { YAW } 93 \\
\text { FSW } 179 \\
\text { SDW } 258 \\
\text { AIP I } \\
\text { YAW } 108\end{array}$ & $\begin{array}{r}15.5 \\
9.1 \\
25.3 \\
53.7 \\
44.2 \\
6.3\end{array}$ & $\begin{array}{r}14.5 \\
10.2 \\
29.4 \\
58.9 \\
47.3 \\
6.6\end{array}$ & $\begin{array}{l}23,25,5 \\
23,34,5 \\
23,53,5 \\
23,54,5 \\
24,17,5 \\
24,21,5\end{array}$ & $\begin{array}{l}\text { MIW } 21 \\
\text { AIW } 260 \\
\text { YAW } 117 \\
\text { YAW } 96 \\
\text { FSW } 173 \\
\text { MIW } 19\end{array}$ & $\begin{array}{r}23.2 \\
6.8 \\
7.4 \\
5.2 \\
29.8 \\
26.9\end{array}$ & $\begin{array}{r}20.4 \\
9.1 \\
7.4 \\
6.2 \\
27.8 \\
23.8\end{array}$ \\
\hline $\begin{array}{l}19,31,5 \\
19,42,5 \\
19,43,5 \\
19,45,5 \\
19,48,5 \\
20,18,5\end{array}$ & $\begin{array}{l}\text { AIW } 263 \\
\text { AIW } 293 \\
\text { AIW } 292 \\
\text { AIW } 287 \\
\text { YAW } 85 \\
\text { SDW } 262\end{array}$ & $\begin{array}{l}38.2 \\
34.0 \\
34.1 \\
30.1 \\
22.7 \\
47.6\end{array}$ & $\begin{array}{l}43.3 \\
33.2 \\
31.6 \\
25.0 \\
19.5 \\
47.8\end{array}$ & $\begin{array}{r}24,50,5 \\
25,9,5 \\
25,18,5 \\
25,19,5 \\
25,34,5 \\
26,18,5\end{array}$ & $\begin{array}{l}\text { YAW } 94 \\
\text { FSW } 172 \\
\text { FSW } 175 \\
\text { FSW } 176 \\
\text { AIW } 307 \\
\text { FSW } 185\end{array}$ & $\begin{array}{r}7.7 \\
7.9 \\
25.7 \\
22.4 \\
5.0 \\
19.7\end{array}$ & $\begin{array}{r}7.2 \\
13.2 \\
21.6 \\
21.0 \\
5.4 \\
16.3\end{array}$ \\
\hline $\begin{array}{l}20,31,5 \\
20,31,5 \\
20,37,5 \\
20,45,5 \\
20,46,5\end{array}$ & $\begin{array}{l}\text { AlW } 267 \\
\text { AlW } 3 \mid 3 \\
\text { AlW } 254 \\
\text { AlW } 289 \\
\text { AIW } 297\end{array}$ & $\begin{array}{l}33.7 \\
27.5 \\
34.9 \\
29.6 \\
24.8\end{array}$ & $\begin{array}{l}36.8 \\
36.8 \\
31.6 \\
25.3 \\
20.6\end{array}$ & $\begin{array}{l}27,23,5 \\
28,12,5 \\
28,17,5 \\
31,22,5\end{array}$ & $\begin{array}{l}\text { MIW } 29 \\
\text { FSW 181 } \\
\text { FSW } 5 \\
\text { MIW } 18\end{array}$ & $\begin{array}{l}6.4 \\
5.7 \\
6.2 \\
3.0\end{array}$ & $\begin{array}{l}7.0 \\
8.9 \\
7.6 \\
3.4\end{array}$ \\
\hline
\end{tabular}




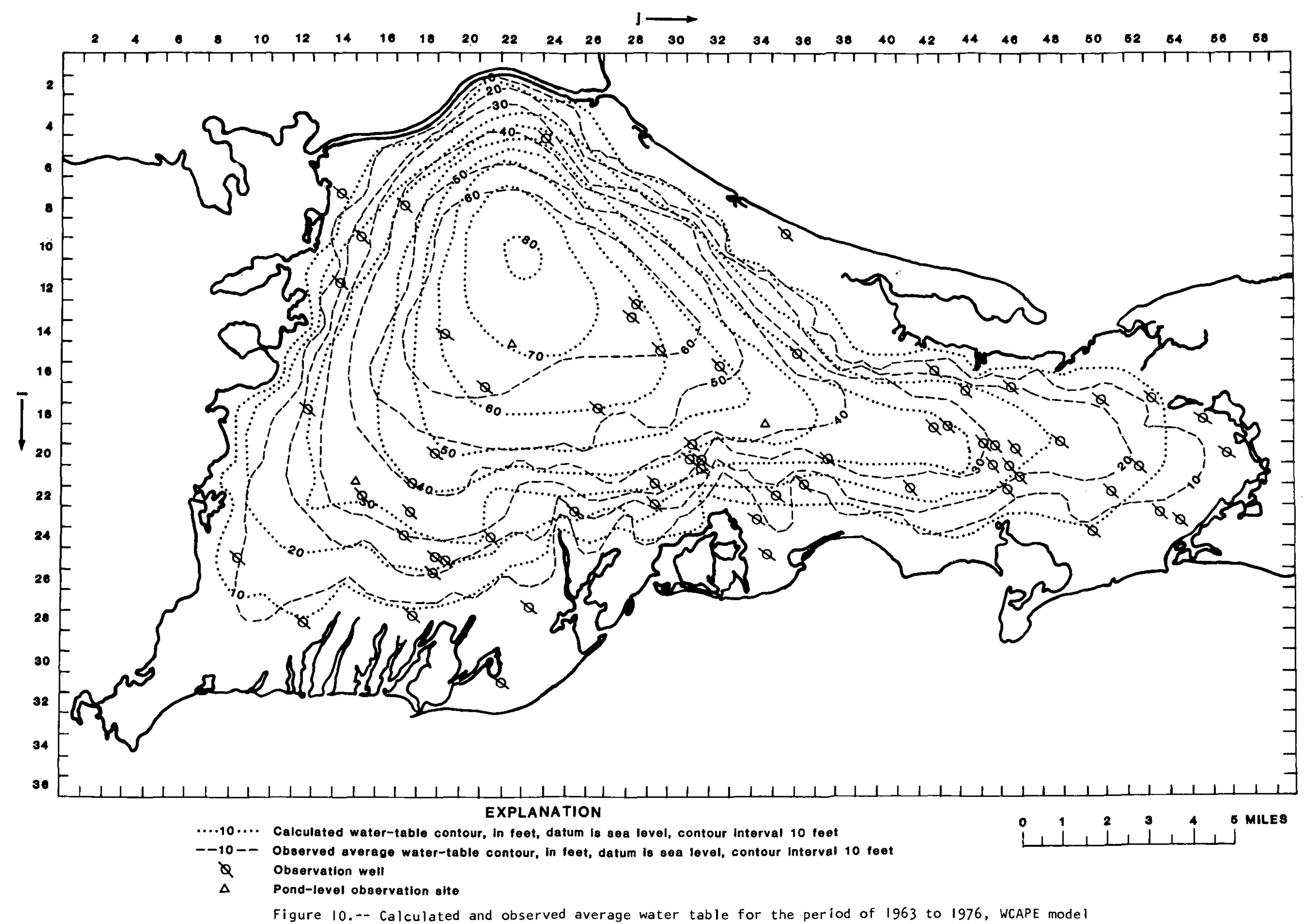




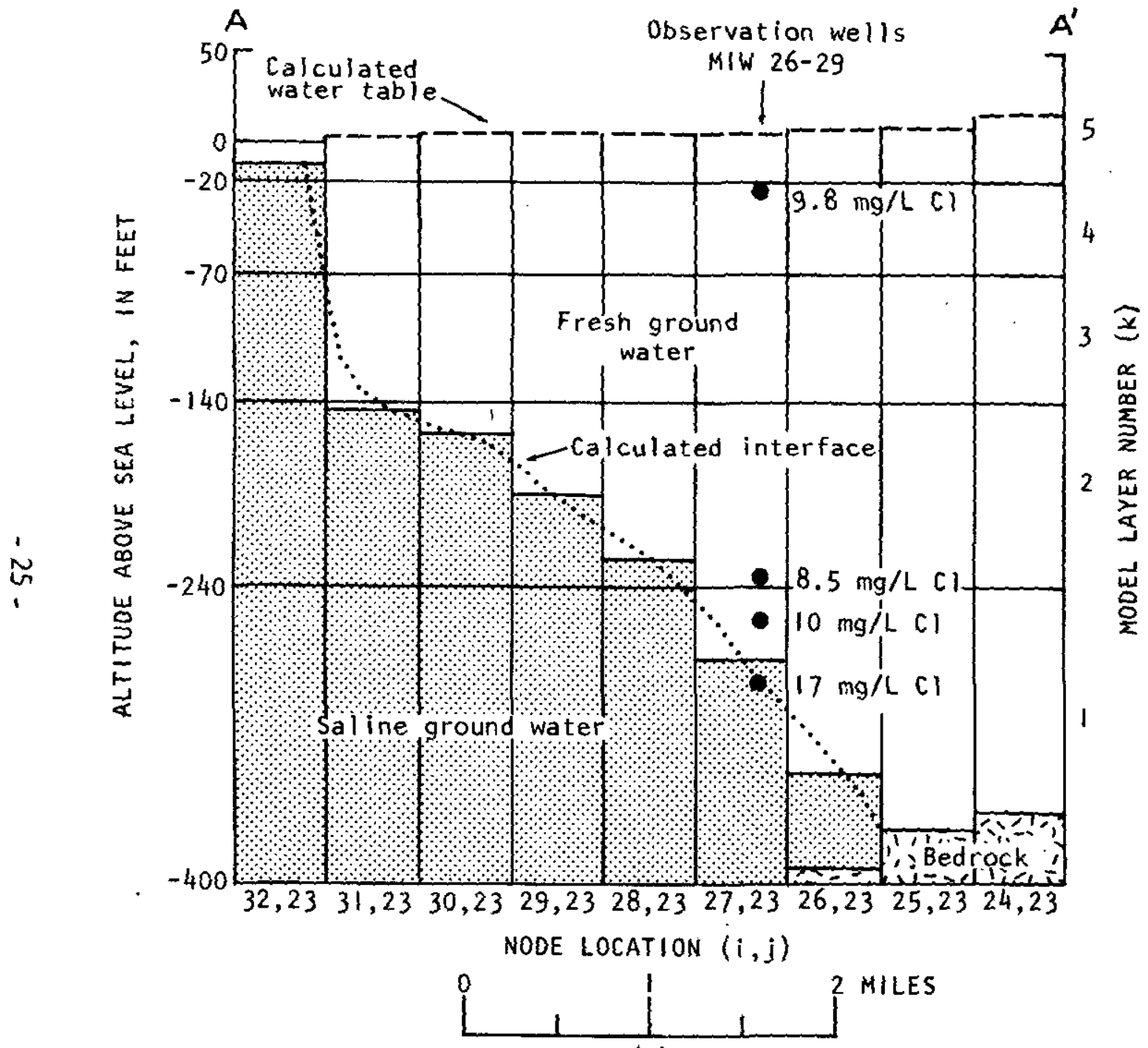

(a)

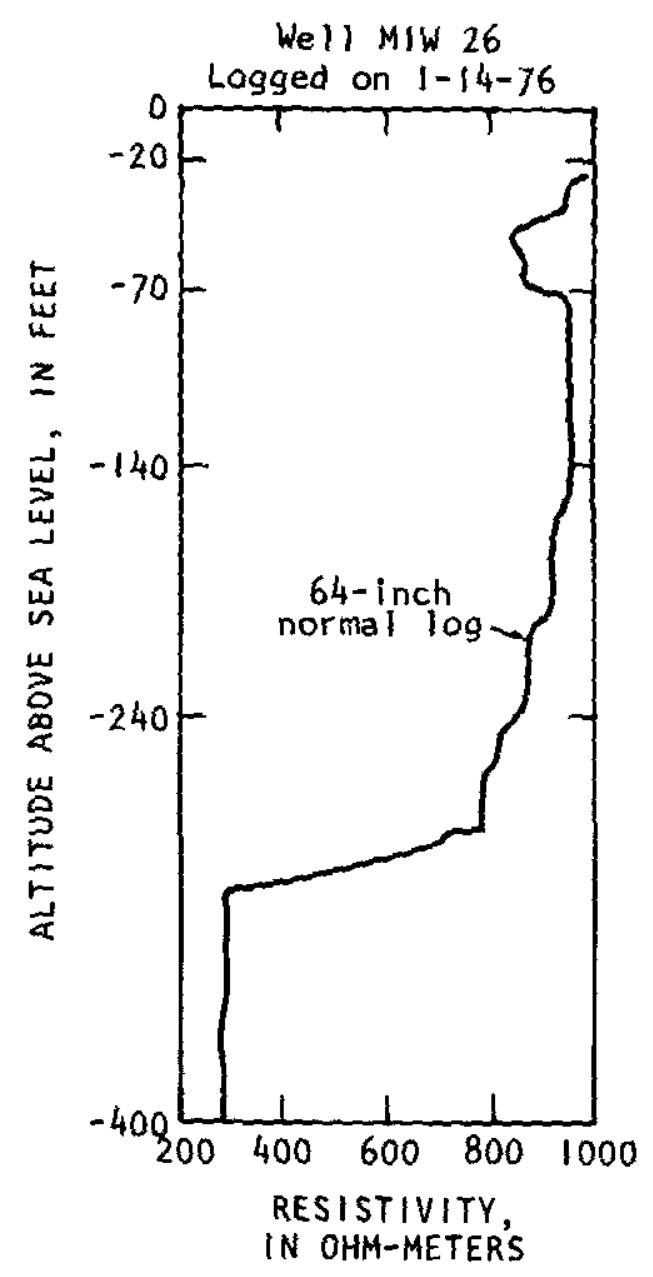

(b)

Figure 11.-(a) Calculated water table, interface between fresh and suline ground water, chloride (Cl) content, in milligrams per liter ( $\mathrm{mg} / \mathrm{L}$ ), of water samples collected from wells on June 20 , 1979 , and (b) resistivity log for well MIW 26. Line of cross section A-A' is shown in figure 3 . 

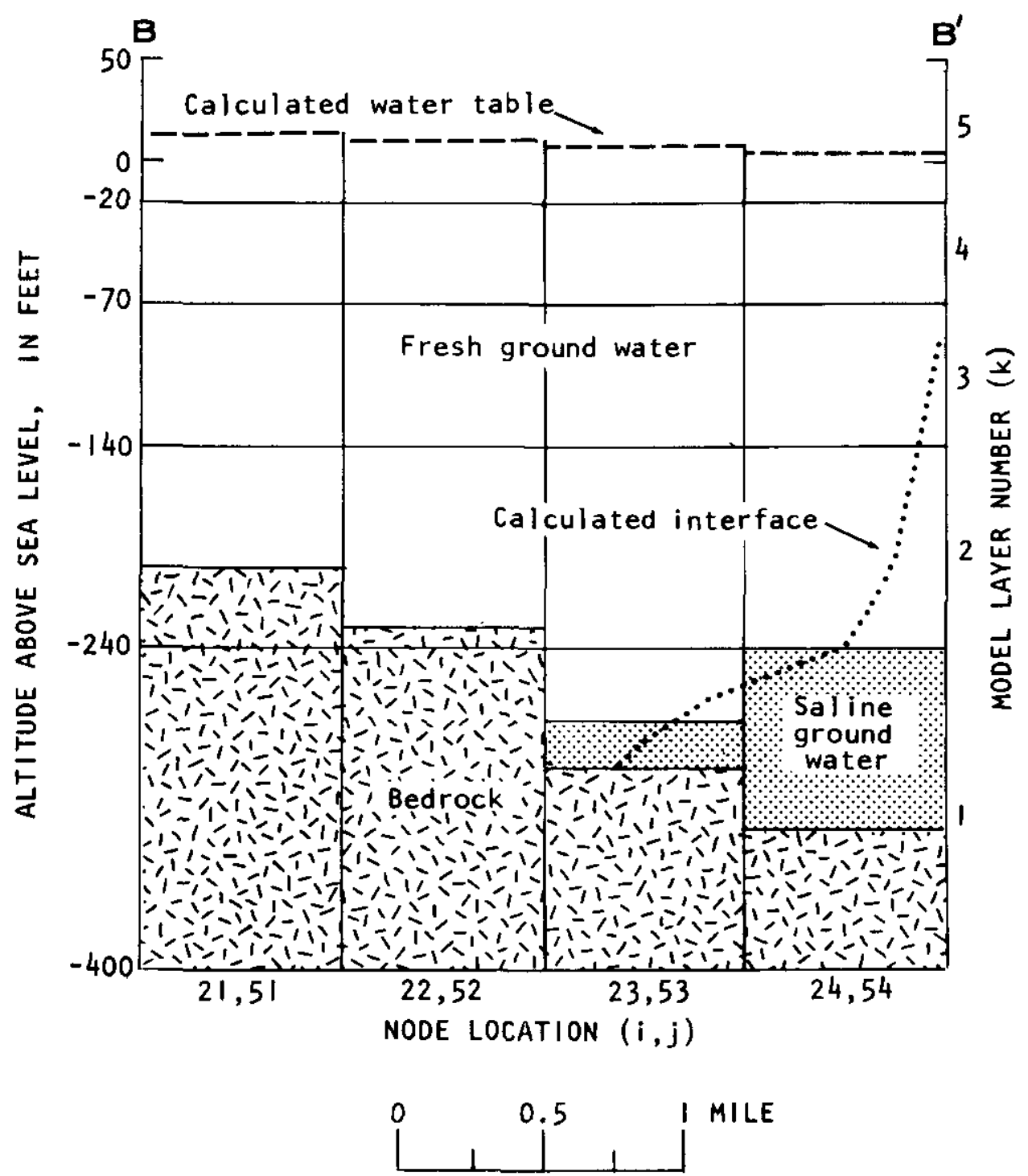

Figure 12.-Calculated water table and interface between fresh and saline ground water. Line of cross section $\mathrm{B}^{-\mathrm{B}^{\prime}}$ is shown in figure 3 . 


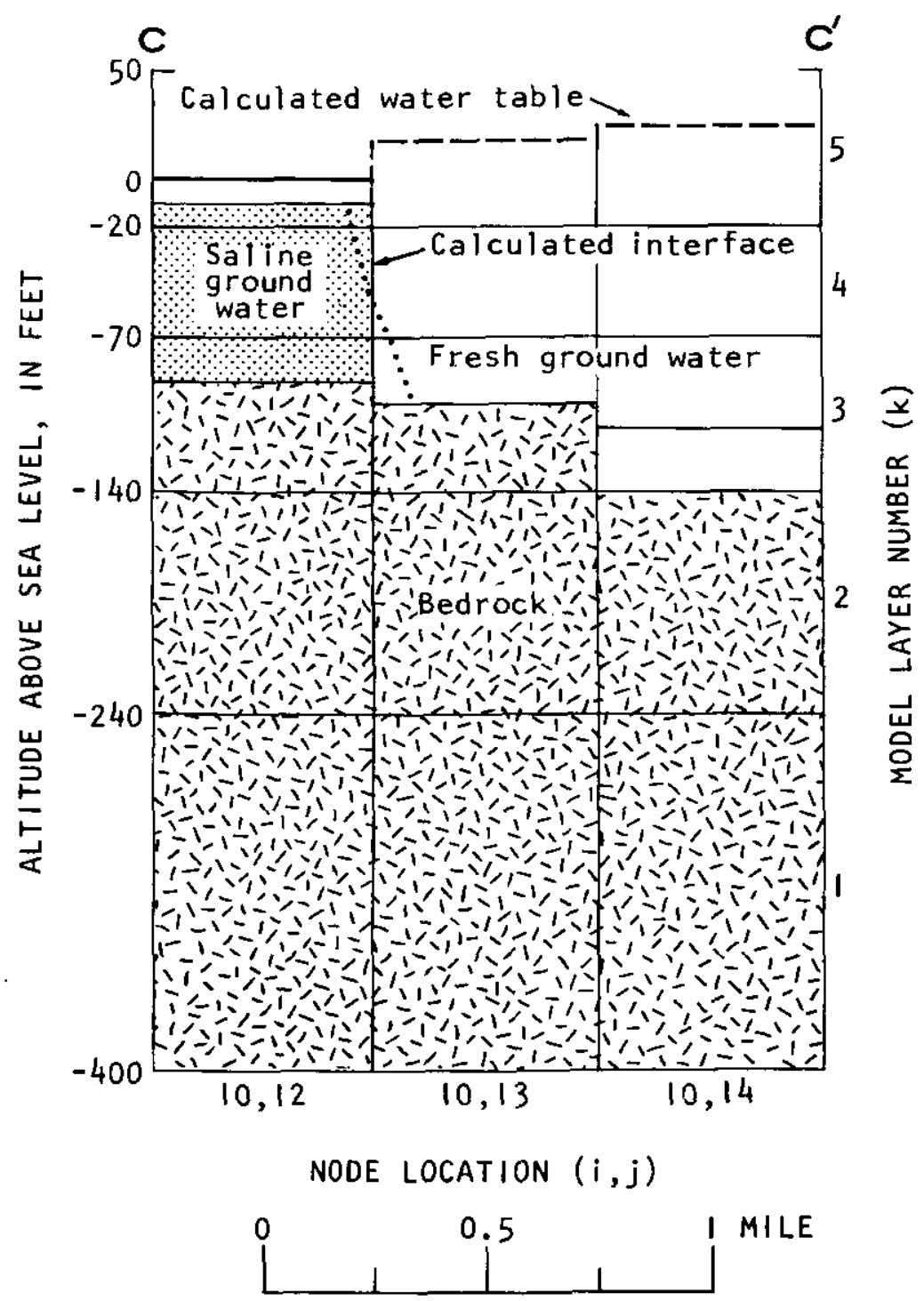

Figure 13.--Calculated water table and interface between fresh and saline ground water. Line of cross section $C-C^{\prime}$ is shown in figure 3 . 


\section{ECAPE Model}

For the ECAPE model, agreement between the observed average water levels and the calculated water levels is shown by table 5 and figure 14. Disagreement is generally in the area where the outwash plains overlie moraine deposits. The model was not able to simulate the 40-foot water-level contour in Dennis (fig. 14), nor was it able to simulate the water levels observed deep in the aquifer in the northern part of Dennis. The complex stratigraphy associated with moraine deposits is probably not adequately approximated by the model in this area. Improvement of this portion of the model will require additional hydrogeologic information.

The calculated position of the interface between fresh and saline ground water for a selected cross section (D-D' on fig. 4) is shown in figure 15.

The mass balance calculated for the ECAPE model indicates that the steady-state recharge to the aquifer is $91 \mathrm{ft}^{3} / \mathrm{s}$, withdrawal by pumpage is $7 \mathrm{ft}^{3} / \mathrm{s}$ and discharge to streams, marshes, and the ocean is $84 \mathrm{ft}^{3} / \mathrm{s}$.

Table 5.-Comparison of calculated nodal head values and observed average water levels for the period 1963 to 1976 for selected wells, ECAPE model

\begin{tabular}{|c|c|c|c|c|c|c|c|}
\hline \multirow[t]{2}{*}{$\begin{array}{l}\text { Node } \\
(i, j, k)\end{array}$} & \multirow{2}{*}{$\begin{array}{l}\text { U.S. } \\
\text { Geological } \\
\text { Survey } \\
\text { well }\end{array}$} & \multicolumn{2}{|c|}{$\begin{array}{c}\text { Water level, in feet } \\
\text { above sea level }\end{array}$} & \multirow[t]{2}{*}{$\begin{array}{l}\text { Node } \\
(i, j, k)\end{array}$} & \multirow{2}{*}{$\begin{array}{l}\text { U.S. } \\
\text { Geological } \\
\text { Survey } \\
\text { well }\end{array}$} & \multicolumn{2}{|c|}{$\begin{array}{c}\text { Water level, in feet } \\
\text { above sea level }\end{array}$} \\
\hline & & $\begin{array}{l}\text { observed } \\
\text { average }\end{array}$ & $\begin{array}{l}\text { calculated } \\
\text { at center } \\
\text { of grid } \\
\text { block }\end{array}$ & & & $\begin{array}{l}\text { observed } \\
\text { average }\end{array}$ & $\begin{array}{l}\text { calculated } \\
\text { at center } \\
\text { of grid } \\
\text { block }\end{array}$ \\
\hline $\begin{array}{r}5,31,5 \\
6,24,5 \\
6,27,5 \\
8,27,5 \\
8,29,5 \\
9,6,5\end{array}$ & $\begin{array}{l}\text { OSW } 22 \\
\text { BMW } 22 \\
\text { OSW } 25 \\
\text { OSP I } \\
\text { OSP } 3 \\
\text { DGW I } 70\end{array}$ & $\begin{array}{r}4.2 \\
19.8 \\
15.1 \\
21.7 \\
7.5 \\
6.4\end{array}$ & $\begin{array}{r}5.2 \\
12.9 \\
14.0 \\
21.0 \\
15.1 \\
6.5\end{array}$ & $\begin{array}{l}11,25,5 \\
12,10,5 \\
12,12,5 \\
12,18,5 \\
12,19,5 \\
12,20,5\end{array}$ & $\begin{array}{l}\text { BMW } 46 \\
\text { DGW } 107 \\
\text { DGW } 157 \\
\text { HJP } 3 \\
\text { HJP } 3 \\
\text { HJP } 3\end{array}$ & $\begin{array}{l}27.5 \\
20.6 \\
25.9 \\
31.6 \\
31.6 \\
31.6\end{array}$ & $\begin{array}{l}26.2 \\
25.0 \\
30.6 \\
31.1 \\
31.0 \\
31.0\end{array}$ \\
\hline $\begin{array}{l}9,16,5 \\
9,24,5 \\
9,24,5 \\
9,25,5 \\
9,26,5 \\
9,29,5\end{array}$ & $\begin{array}{l}\text { BMW } 44 \\
\text { BMP } 3 \\
\text { BMW 21 } \\
\text { BMP } 5 \\
\text { BMP } 5 \\
\text { OSP } 3\end{array}$ & $\begin{array}{r}26.4 \\
28.0 \\
27.2 \\
25.8 \\
25.8 \\
7.5\end{array}$ & $\begin{array}{l}25.3 \\
27.2 \\
27.2 \\
26.1 \\
24.6 \\
14.8\end{array}$ & $\begin{array}{l}13,12,5 \\
13,18,5 \\
13,20,5 \\
13,21,5 \\
14,10,5 \\
14,12,5\end{array}$ & $\begin{array}{l}\text { DGW } 88 \\
\text { HJP } 3 \\
\text { HJP } 3 \\
\text { HJP } 3 \\
\text { DGW } 158 \\
\text { DGP } 7\end{array}$ & $\begin{array}{l}25.9 \\
31.6 \\
31.6 \\
31.6 \\
19.2 \\
27.0\end{array}$ & $\begin{array}{l}27.7 \\
31.2 \\
31.1 \\
30.8 \\
17.7 \\
26.1\end{array}$ \\
\hline $\begin{array}{r}10,8,5 \\
10,8,5 \\
10,11,5 \\
10,12,5 \\
10,12,5 \\
10,28,5\end{array}$ & $\begin{array}{ll}\text { DGW } & 100 \\
\text { DGW } & 114 \\
\text { DGW } & 143 \\
\text { DGW } & 123 \\
\text { DGW } & 144 \\
\text { OSW } & 24\end{array}$ & $\begin{array}{l}44.7 \\
28.3 \\
30.5 \\
32.8 \\
30.6 \\
18.5\end{array}$ & $\begin{array}{l}25.8 \\
25.8 \\
33.7 \\
33.6 \\
33.6 \\
17.8\end{array}$ & $\begin{array}{l}14,15,5 \\
14,25,5 \\
15,22,5 \\
15,25,5 \\
16,12,5 \\
17,18,5\end{array}$ & $\begin{array}{l}\text { HJW } 145 \\
\text { HJW } 141 \\
\text { HJW } 150 \\
\text { HJW } 151 \\
\text { DGW } 160 \\
\text { HJW } 148\end{array}$ & $\begin{array}{r}31.7 \\
19.2 \\
30.3 \\
11.4 \\
8.2 \\
20.8\end{array}$ & $\begin{array}{l}29.0 \\
20.5 \\
28.3 \\
19.6 \\
14.2 \\
22.4\end{array}$ \\
\hline $\begin{array}{r}11,8,5 \\
11,8,5 \\
11,9,5 \\
11,10,5 \\
11,10,5 \\
11,11,5\end{array}$ & $\begin{array}{l}\text { DGW } 124 \\
\text { DGP } 4 \\
\text { DGW } 135 \\
\text { DGP } 2 \\
\text { DGP } 3 \\
\text { DGW } 146\end{array}$ & $\begin{array}{l}16.9 \\
24.5 \\
16.7 \\
20.3 \\
20.9 \\
25.7\end{array}$ & $\begin{array}{l}21.9 \\
21.9 \\
25.6 \\
29.3 \\
29.3 \\
31.9\end{array}$ & $\begin{array}{l}17,26,5 \\
18,25,5 \\
18,25,5 \\
18,26,5 \\
18,28,5 \\
19,23,5\end{array}$ & $\begin{array}{l}\text { CGP } 4 \\
\text { CGW 176 } \\
\text { CGP } 5 \\
\text { CGP } 3 \\
\text { CGW } 177 \\
\text { CGW I38 }\end{array}$ & $\begin{array}{l}10.4 \\
12.5 \\
12.8 \\
12.7 \\
11.9 \\
11.3\end{array}$ & $\begin{array}{l}16.3 \\
16.8 \\
16.8 \\
15.6 \\
11.9 \\
12.9\end{array}$ \\
\hline $\begin{array}{l}11,11,5 \\
11,18,5\end{array}$ & $\begin{array}{l}\text { DGP } 6 \\
\text { BMW } 45\end{array}$ & $\begin{array}{l}27.6 \\
31.4\end{array}$ & $\begin{array}{l}31.9 \\
30.6\end{array}$ & $19,27,5$ & CGP I & 14.8 & 9.7 \\
\hline
\end{tabular}




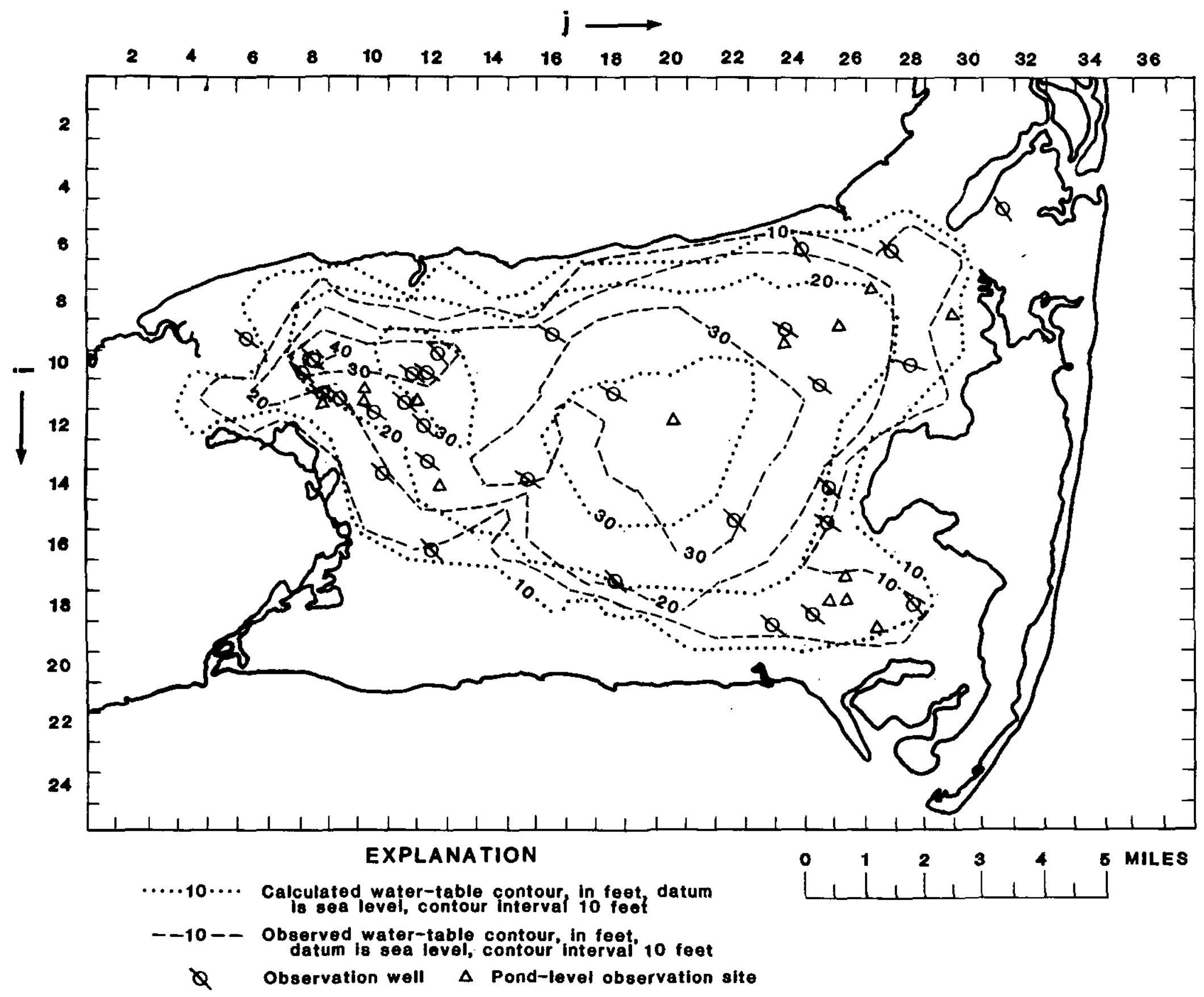

Figure 14.-- Calculated and observed average water table for the period of 1963 to 1976, ECAPE mOdel 


\section{ESTHM Model}

Table 6 and figure 16 show the agreement between the calculated and observed average water levels for the ESTHM model.

The mass balance calculations indicate that the steady-state rate of aquifer recharge is $19 \mathrm{ft}^{3} / \mathrm{s}$. This rate is balanced by an equal rate of discharge to streams, marshes, and the ocear.

Table 6.-Comparison of calculated nodal head values and observed average water levels for the period 1963 to 1976 for selected wells, ESTHM model

\begin{tabular}{|c|c|c|c|c|c|c|c|}
\hline \multirow[t]{2}{*}{$\begin{array}{l}\text { Node } \\
(i, j, k)\end{array}$} & \multirow{2}{*}{$\begin{array}{l}\text { U.S. } \\
\text { Geological } \\
\text { Survey } \\
\text { well }\end{array}$} & \multicolumn{2}{|c|}{$\begin{array}{c}\text { Water level, in feet } \\
\text { above sea level }\end{array}$} & \multirow[t]{2}{*}{$\begin{array}{l}\text { Node } \\
(i, j, k)\end{array}$} & \multirow{2}{*}{$\begin{array}{l}\text { U.S. } \\
\text { Geological } \\
\text { Survey } \\
\text { well }\end{array}$} & \multicolumn{2}{|c|}{$\begin{array}{c}\text { Water level, in feet } \\
\text { above sea level }\end{array}$} \\
\hline & & $\begin{array}{l}\text { observed } \\
\text { average }\end{array}$ & $\begin{array}{l}\text { calculated } \\
\text { at center } \\
\text { of grid } \\
\text { block }\end{array}$ & & & $\begin{array}{l}\text { observed } \\
\text { average }\end{array}$ & $\begin{array}{l}\text { calculated } \\
\text { at center } \\
\text { of grid } \\
\text { block }\end{array}$ \\
\hline $\begin{array}{r}8,13,7 \\
12,16,7 \\
13,31,7\end{array}$ & $\begin{array}{l}\text { EGW } 37 \\
\text { EGW } 39 \\
\text { WNW } 17\end{array}$ & $\begin{array}{r}8.0 \\
13.8 \\
8.7\end{array}$ & $\begin{array}{r}8.2 \\
13.5 \\
8.3\end{array}$ & $\begin{array}{l}14,19,7 \\
15,19,7 \\
16,18,7\end{array}$ & $\begin{array}{l}\text { EGW } 36 \\
\text { EGW } 32 \\
\text { EGW } 40\end{array}$ & $\begin{array}{r}13.5 \\
12.8 \\
8.6\end{array}$ & $\begin{array}{l}13.9 \\
13.1 \\
11.7\end{array}$ \\
\hline
\end{tabular}

\section{WLFLT Model}

The agreement between the observed average water levels and calculated water levels for the WLFLT model is shown by table 7 and figure 17.

Mass balance calculations indicate that the steady-state recharge rate, $23 \mathrm{ft} 3 / \mathrm{s}$, is balanced by an equal rate of discharge to streams, marshes, and the ocean.

Table 7.-Comparison of calculated nodal head values and observed average water levels for the period 1963 to 1976 for selected wells, WLFLT model

\begin{tabular}{|c|c|c|c|c|c|c|c|}
\hline \multirow[t]{2}{*}{$\begin{array}{l}\text { Node } \\
(i, j, k)\end{array}$} & \multirow{2}{*}{$\begin{array}{l}\text { U.S. } \\
\text { Geological } \\
\text { Survey } \\
\text { well }\end{array}$} & \multicolumn{2}{|c|}{$\begin{array}{c}\text { Water level, in feet } \\
\text { above sea level }\end{array}$} & \multirow[t]{2}{*}{$\begin{array}{l}\text { Node } \\
(i, j, k)\end{array}$} & \multirow{2}{*}{$\begin{array}{c}\text { U.S. } \\
\text { Geological } \\
\text { Survey } \\
\text { well }\end{array}$} & \multicolumn{2}{|c|}{$\begin{array}{c}\text { Water level, in feet } \\
\text { above sea level }\end{array}$} \\
\hline & & $\begin{array}{l}\text { observed } \\
\text { average }\end{array}$ & $\begin{array}{l}\text { calculated } \\
\text { at center } \\
\text { of grid } \\
\text { block }\end{array}$ & & & $\begin{array}{l}\text { observed } \\
\text { average }\end{array}$ & $\begin{array}{l}\text { calculated } \\
\text { at center } \\
\text { of grid } \\
\text { block }\end{array}$ \\
\hline $\begin{array}{r}6,16,7 \\
11,26,7 \\
15,14,7 \\
16,14,7 \\
16,21,7\end{array}$ & $\begin{array}{l}\text { WNW } 78 \\
\text { TSW } 216 \\
\text { WNW } 30 \\
\text { WNW } 30 \\
\text { TSP } 17\end{array}$ & $\begin{array}{l}2.7 \\
4.1 \\
6.6 \\
6.6 \\
6.8\end{array}$ & $\begin{array}{l}3.4 \\
5.3 \\
6.7 \\
7.4 \\
7.2\end{array}$ & $\begin{array}{l}16,26,7 \\
17,22,7 \\
18,17,7 \\
21,19,7\end{array}$ & $\begin{array}{l}\text { TSW } 198 \\
\text { TSP } 16 \\
\text { WNW } 34 \\
\text { TSP } 18\end{array}$ & $\begin{array}{l}7.6 \\
7.6 \\
8.0 \\
6.4\end{array}$ & $\begin{array}{l}7.1 \\
7.9 \\
8.0 \\
6.5\end{array}$ \\
\hline
\end{tabular}




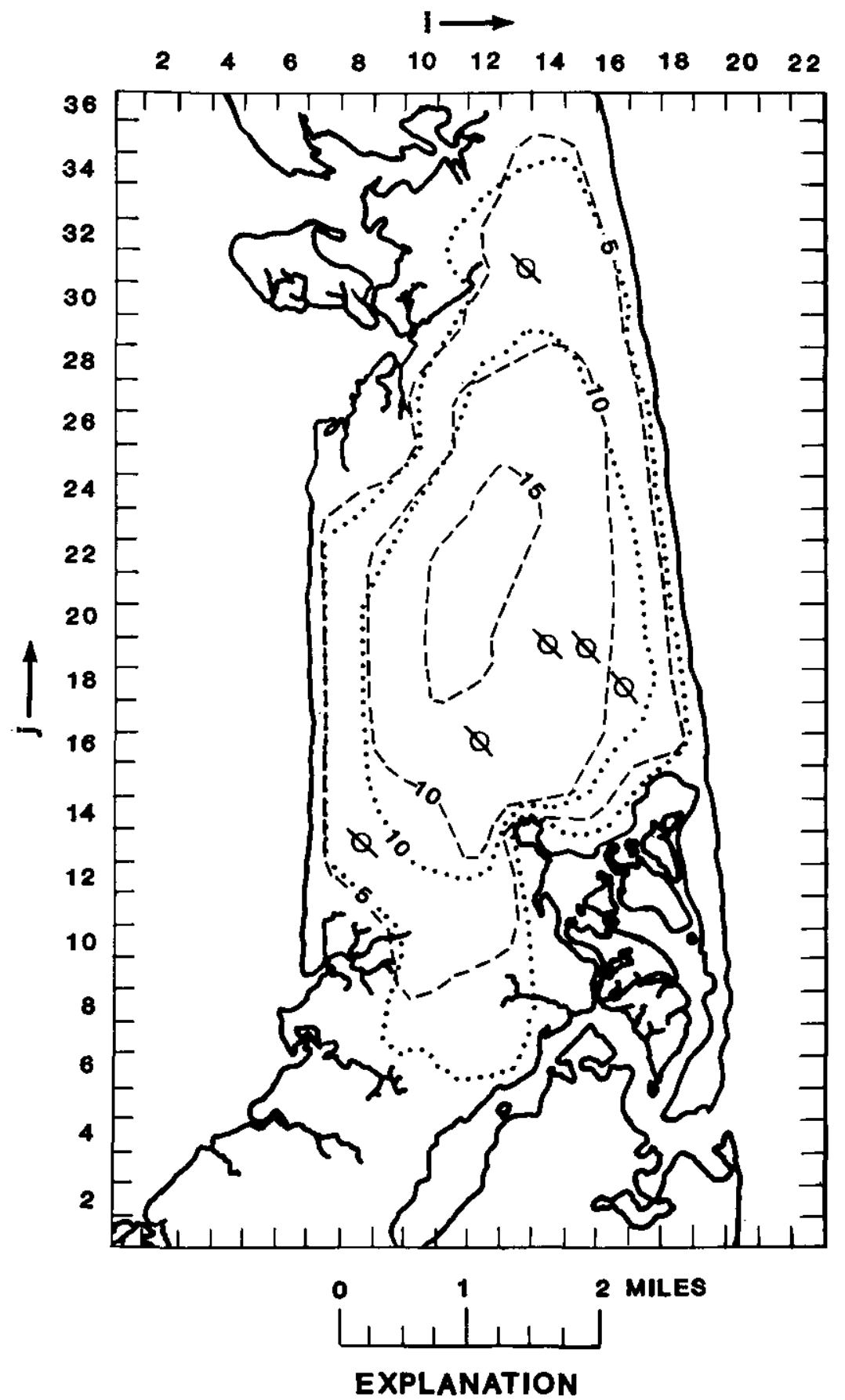

...5 ... Calculated water-table contour, in feet, datum is sea level, contour intervai 5 feet

- -6- - Observed average water-table contour, in feet, datum is sea level, contour interval 6 feet

Q Observation well

Figure 16.-- Calculated and observed average water table for the period of 1963 to 1976, ESTHM model 


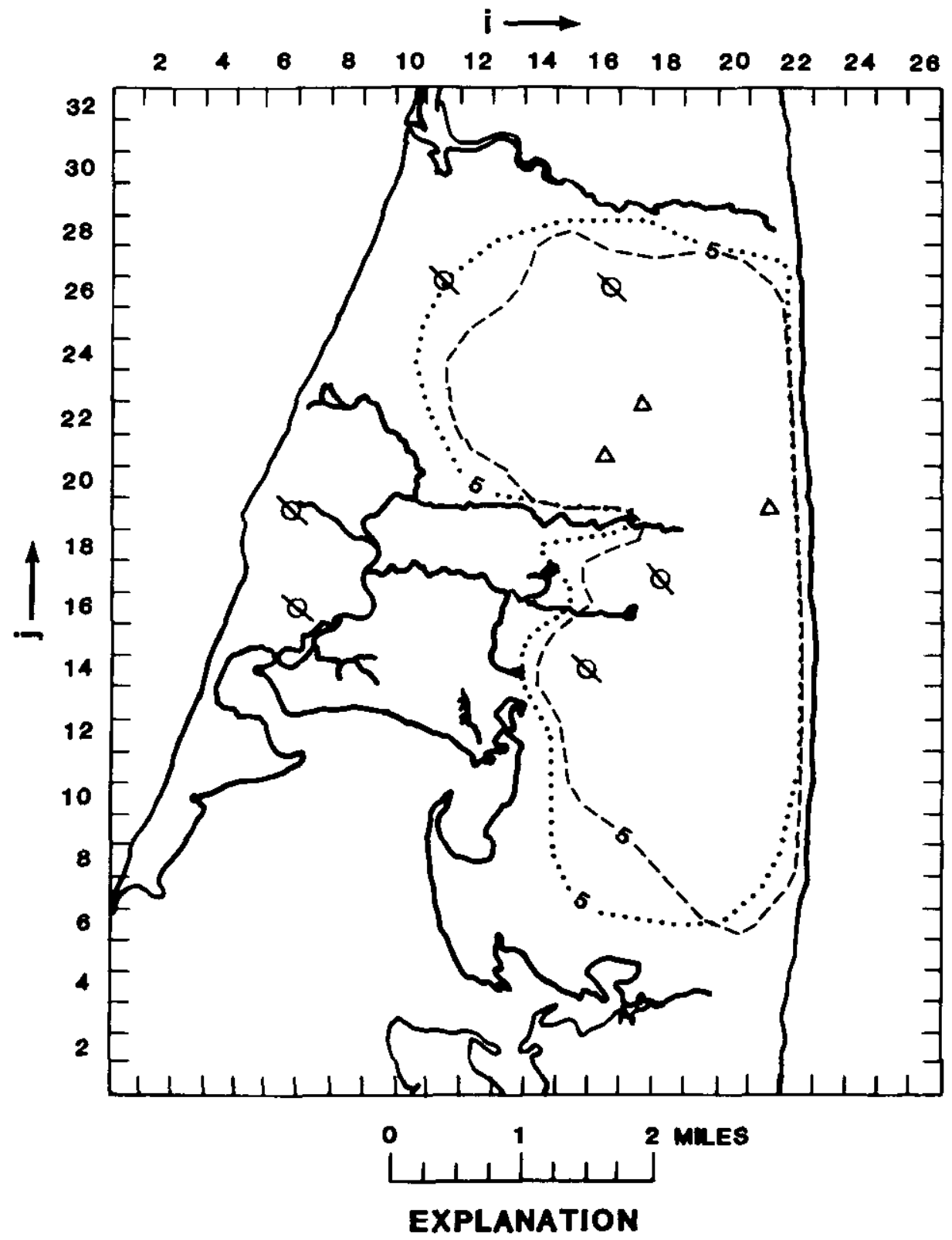

...5 -.. Calculated water-table contour, in feet, datum is sea level, contour interval 5 feet

- 5 - Observed average water-table contour,in feet,
datum is sea fevel, contour interval' feet

Q Observation well

$\Delta \quad$ Pond-level observation site

Figure 17.-- Calculated and observed average water table for the period of 1963 to 1976, WLFLT model 


\section{TRURO Model}

The agreement between the observed average water levels and calculated water levels for the TRURO model is shown by table 8 and figure 18. Mass balance calculations for the TRURO model indicate a steady-state recharge rate of $12.3 \mathrm{ft}^{3} / \mathrm{s}$, withdrawal by pumping of $1.4 \mathrm{ft}^{3} / \mathrm{s}$, and discharge to the streams, marshes, and the ocean at a rate of $10.9 \mathrm{ft} / \mathrm{s}$.

Figure 19 shows the calculated position of the interface between fresh and saline ground water along cross section E-E' shown on figure 7. Measured chloride concentrations of water samples collected from a group of wells near that line of section are also included for comparison.

Table 8.-Comparison of calculated nodal head values and observed average water levels for the period 1963 to 1976 for selected wells, TRURO model

\begin{tabular}{|c|c|c|c|c|c|c|c|}
\hline \multirow[t]{2}{*}{$\begin{array}{l}\text { Node } \\
(i, j, k)\end{array}$} & \multirow{2}{*}{$\begin{array}{l}\text { U.S. } \\
\text { Geological } \\
\text { Survey } \\
\text { well }\end{array}$} & \multicolumn{2}{|c|}{$\begin{array}{l}\text { Water level, in feet } \\
\text { above sea level }\end{array}$} & \multirow[t]{2}{*}{$\begin{array}{l}\text { Node } \\
(i, j, k)\end{array}$} & \multirow{2}{*}{$\begin{array}{l}\text { U.S. } \\
\text { Geological } \\
\text { Survey } \\
\text { well }\end{array}$} & \multicolumn{2}{|c|}{$\begin{array}{c}\text { Water level, in feet } \\
\text { above sea level }\end{array}$} \\
\hline & & $\begin{array}{l}\text { observed } \\
\text { average }\end{array}$ & $\begin{array}{l}\text { calculated } \\
\text { at center } \\
\text { of grid } \\
\text { block }\end{array}$ & & & $\begin{array}{l}\text { observed } \\
\text { average }\end{array}$ & $\begin{array}{l}\text { calculated } \\
\text { at center } \\
\text { of grid } \\
\text { block }\end{array}$ \\
\hline $\begin{array}{r}8,14,7 \\
10,6,7 \\
10,8,7 \\
10,16,7 \\
10,17,7 \\
10,19,7 \\
10,20,7\end{array}$ & $\begin{array}{ll}\text { TSW } & 157 \\
\text { TSW } & 176 \\
\text { TSW } & 170 \\
\text { TSW } & 89 \\
\text { TSW } & 89 \\
\text { TSW } & 136 \\
\text { TSW } & 126\end{array}$ & $\begin{array}{l}4.4 \\
5.6 \\
5.9 \\
4.4 \\
4.4 \\
4.3 \\
4.2\end{array}$ & $\begin{array}{l}3.8 \\
5.6 \\
6.1 \\
5.2 \\
5.0 \\
4.6 \\
4.3\end{array}$ & $\begin{array}{r}11,5,7 \\
12,3,7 \\
12,4,7 \\
12,18,7 \\
13,8,7 \\
14,6,7\end{array}$ & $\begin{array}{l}\text { TSW } 218 \\
\text { TSW } 181 \\
\text { TSW } 181 \\
\text { TSW } 134 \\
\text { TSW } 203 \\
\text { TSW } 174\end{array}$ & $\begin{array}{l}5.2 \\
4.7 \\
4.7 \\
4.9 \\
5.7 \\
5.6\end{array}$ & $\begin{array}{l}5.4 \\
3.6 \\
4.9 \\
4.5 \\
6.0 \\
5.0\end{array}$ \\
\hline
\end{tabular}

\section{SUMMARY AND CONCLUSIONS}

Cape Cod satisfies its water-supply demands almost entirely from the freshwater contained within the unconsolidated sediments of Pleistocene and Holocene age. Management of this ground-water resource requires an understanding of the behavior of this large complex aquifer system. Three-dimensional finite-difference ground-water-flow models were prepared for five areas of Cape Cod to provide information on the regional behavior of this system.

The models were developed on the basis that the boundary between fresh and saline ground water could be treated as an interface, the saline-water zone is static, and the natural discharge boundaries presently subdivide the aquifer system into individual small aquifers which can be modeled separately.

The models were calibrated for steady-state conditions by comparing calculated and observed water levels, position of the interface between fresh and saline ground water, and ground-water discharge rates at approximately 150, 27, and 2 control points, respectively.

The accuracy of the model results is limited by the accuracy of the input data that describe aquifer properties, boundary conditions, and recharge rates. As additional data become available, the models should be recalibrated to improve model accuracy commensurate with the knowledge available. Continued monitoring of water-level changes, streamflow, and movement of the boundary between fresh and saline ground water in response to natural and man-caused changes in hydrologic stresses will help improve the aquifer models and make them more useful.

The scale of the models precludes detailed analyses of hydrologic conditions for local areas. More detailed smaller-scale models of local areas can be constructed using similar principles provided sufficient data are available.

Mass balance calculations for the five modeled areas indicate a total steady-state natural and artificial recharge rate of $412 \mathrm{ft} 3 / \mathrm{s}$, a total rate of withdrawal by wells of $25 \mathrm{ft}^{3} / \mathrm{s}$, and total discharge rate to streams, marshes, and the ocean of $387 \mathrm{ft} 3 / \mathrm{s}$. 


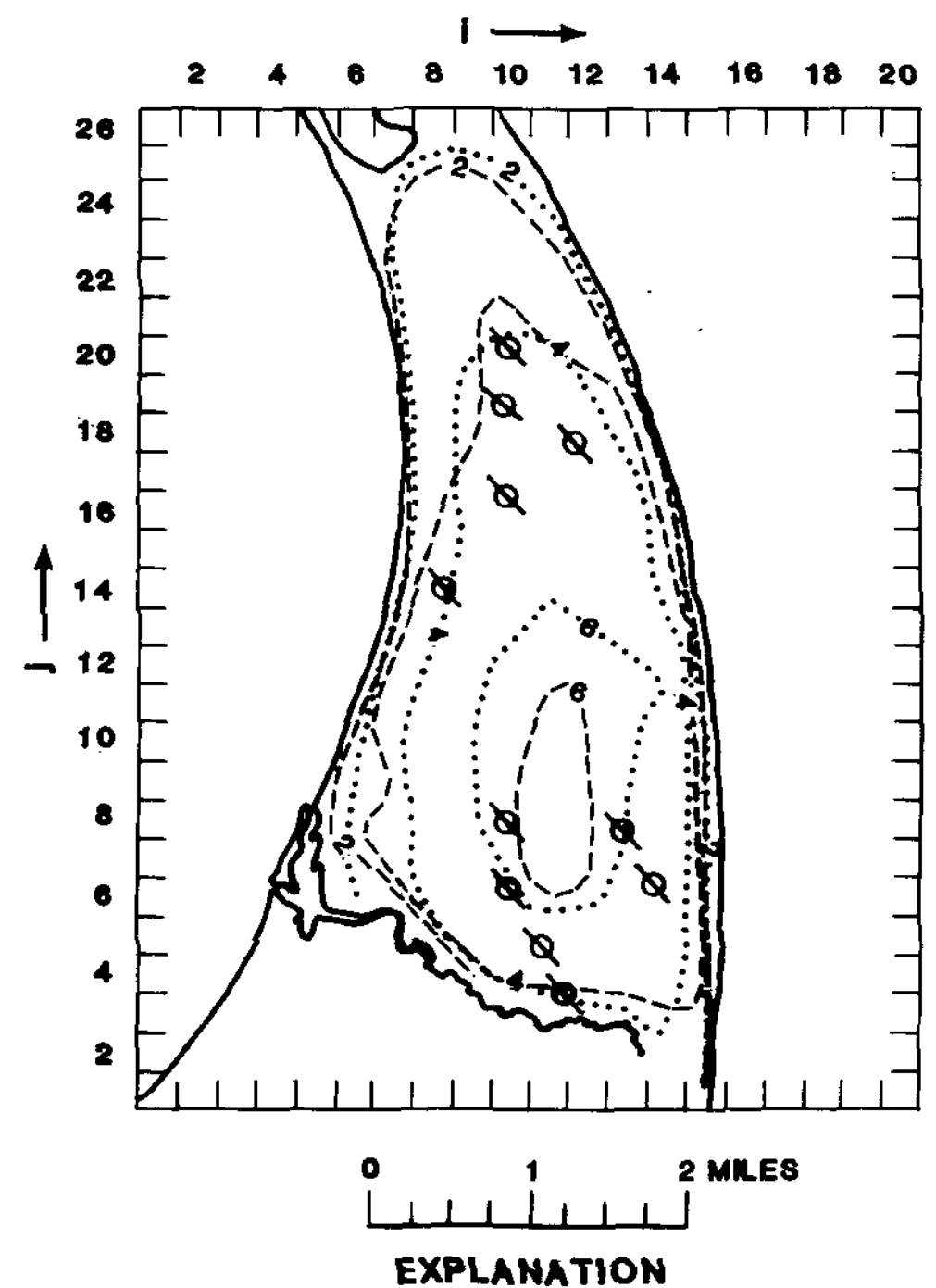

$\cdots 2$... Calculated water-table contour, in feet, datum Io sea level, contour interval 2 feet

- 2 - Observed average water-table contour, in feet, datum is sea level, contour interval' 2 feet

Q Observation well

Figure 18.-- Calculated and observed average water table for the period of 1963 to 1976, TRURO model. 


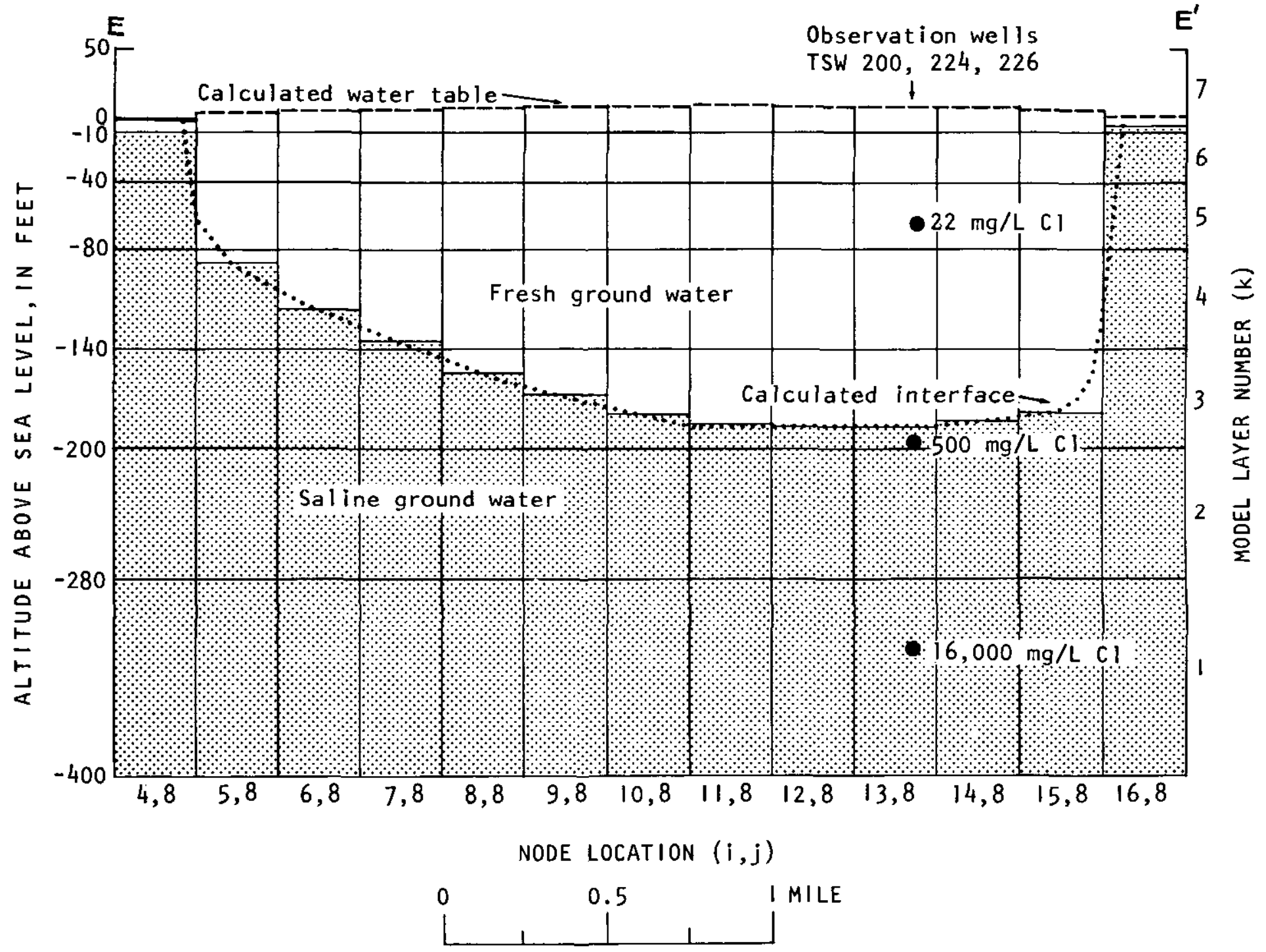

Figure 19.-Calculated water table and interface between fresh and saline ground water, and chloride $(\mathrm{Cl})$ content, in milligrams per liter $(\mathrm{mg} / \mathrm{L})$, of water samples collected from wells on December 5, 1978. Line of cross section E-E' is shown in figure 7. 
Burns, A. W., Frimpter, M. H., and Willey, R. E., 1975, Evaluation of data availability and examples of modeling for ground-water management on Cape Cod, Massachusetts: U.S. Geological Survey Water Resources Investigation 16-75, 22 p.

Getzen, R. T., 1977, Analog-model analysis of regional three-dimensional flow in the ground-water reservoir of Long Island, New York: U.S. Geological Survey Professional Poper 982, $49 \mathrm{p}$.

Guswa, J. H., and Londquist, C. J., 1976, Potential for development of ground water at a test site near Truro, Massachusetts: U.S. Geological Survey Open-File Report 76-614, 22 p.

Hubbert, M. K., 1940, The theory of ground-water motion: Journal of Geology, v. 48, no. 8, p. $785-944$.

Lohman, S. W., and others, 1972, Definitions of selected ground-water terms--Revisions and conceptual refinements: U.S. Geological Survey Water-Supply Paper 1988, 21 p.

Meyer, William, Reussow, J. P., Gillies, D. C., and Shampine, W.J., 1975, Availability of ground water in Marion County, Indiana: U.S. Geological Survey Open-File Report 75-3।2, $87 \mathrm{p}$.

Oldale, R. N., 1969, Seismic investigations on Cape Cod, Martha's Vineyard, and Nantucket, Massachusetts, and a topographic map of the basement surface from Cape Cod Bay to the Islands: U.S. Geological Survey Professional Paper 650-B, P. B|22-BI27.

Oldale, R. N., 1976, Notes on the generalized geologic map of Cape Cod: U.S. Geological Survey Open-File Report 76-765, 23 p.

Palmer, C. D., 1977, Hydrogeological implications of various wastewater management proposals for the Falmouth area of Cape Cod, Massachusetts: Pennsylvania State University, unpublished M.S. thesis, 142 p.

Prickett, T. A., 1975, Modeling techniques for groundwater evaluation, in Advances in hydrosciences, v. 10, edited by V. T. Chow: New York, Academic Press, P. T-143.

Stone, H. L., 1968, Iterative solution of implicit approximations of multidimensional partial differential equations: Society of Industrial and Applied Mathematics, Journal of Numerical Analysis, v. 5, no. 3, p. 530-558.

Strahler, A. N., 1972, The environmental impact of ground water use on Cape Cod: Impact Study III, Association for the Preservation of Cape Cod: Orleans, Mass., 68 p.

Theis, C. V., 1963, Estimating the transmissibility of a water-table aquifer from the specific capacity of a well, in Bentall, Ray, Methods of determining permeability, transmissibility, and drawdown: U.S. Geological Survey Water-Supply Paper I536-l, p. 332-336.

Thornthwaite, C. W., and Mather, J. R., 1957, Instructions and tables for computing potential evapotranspiration and the water balance: Drexel Institute of Technology Publications in Climatology, v. 10, no. 3, p. 185-311.

Trescott, P. C., 1975 Documentation of finite-difference model for simulation of threedimensional ground-water flow: U.S. Geological Survey Open-File Report 75-438, 30 p.

Trescott, P. C., and Larson, S. P., 1976, Supplement to Open-File Report 75-438, Documentation of finite-difference model for simulation of three-dimensional ground-water flow: U.S. Geological Survey Open-File Report 76-59I, 17 p.

Trescott, P. C., Pinder, G. F., and Larson, S. P., 1976, Finite-difference model for aquifer simulation in two dimensions with results of numerical experiments: U.S. Geological Survey Techniques of Water Resources Investigations, Chapter CI, Book 7, p. 42.

U.S. Environmental Protection Agency, 1978, Water Quality Management Plan/EIS for Cape Cod: Draft plan/Environmental Impact Statement.

Walton, W. C., 1970, Groundwater resource evaluation: New York, McGraw-Hill, 664 p. 
SUPPLEMENTAL DATA-MODEL DATA, INPUT DOCUMENTATION, AND SOURCE CODE 
Table 9.--Values for transmissivity, average hydraulic conductivity, and ratio between lateral and vertical

hydraulic conductivity used in model calibrations

$(*$ Values apply uniformly within the modeled area identified in figs. 3-7 of the report.)

\begin{tabular}{|c|c|c|c|c|}
\hline Mode 1 & Layer & $\begin{array}{l}\text { Transmissivity } \\
(\mathrm{T}) \text { for each } \\
\text { node in layer } \\
\left(\mathrm{ft}^{2} / \mathrm{d}\right)\end{array}$ & $\begin{array}{c}\text { Average lateral } \\
\text { hydraulic conduc- } \\
\text { tivity for each } \\
\text { node in layer } \\
(\mathrm{ft} / \mathrm{d})\end{array}$ & $\begin{array}{c}\text { Ratio between } \\
\text { lateral and } \\
\text { vertical } \\
\text { hydraulic } \\
\text { conductivity }\end{array}$ \\
\hline
\end{tabular}

\begin{tabular}{ccccc}
\hline WCAPE & 1 & figure 20 & T for node $/ 160$ & $* 10$ \\
& 2 & figure 21 & T for node $/ 100$ & figure 25 \\
& 3 & figure 22 & T for node $/ 70$ & figure 26 \\
& 4 & figure 23 & T for node $/ 50$ & figure 27 \\
& 5 & NA & figure 24 & figure 28
\end{tabular}

\begin{tabular}{|c|c|c|c|c|}
\hline ECAPE & $\begin{array}{l}1 \\
2 \\
3 \\
4 \\
5\end{array}$ & $\begin{array}{l}\text { figure } 29 \\
\text { figure } 30 \\
\text { figure } 31 \\
\text { figure } 32 \\
\text { NA }\end{array}$ & $\begin{array}{l}T \text { for node } / 160 \\
T \text { for node } / 100 \\
T \text { for node } / 70 \\
T \text { for node } / 50 \\
\text { figure } 33\end{array}$ & $\begin{array}{l}\qquad 10 \\
\text { figure } 34 \\
\text { figure } 35 \\
\text { figure } 36 \\
\text { figure } 37\end{array}$ \\
\hline ESTHM & $\begin{array}{l}1 \\
2 \\
3 \\
4 \\
5 \\
6 \\
7\end{array}$ & $\begin{array}{c}\star 20,250 \\
\star 20,250 \\
\star 13,500 \\
\star 12,150 \\
\text { figure } 38 \\
\text { figure } 39 \\
\text { NA }\end{array}$ & $\begin{array}{c}\star 135 \\
\star 135 \\
\star 135 \\
\star 135 \\
T \text { for node } / 60 \\
T \text { for node } / 40 \\
\text { figure } 40\end{array}$ & 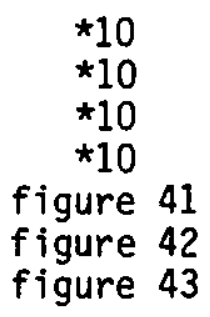 \\
\hline WLFLT & $\begin{array}{l}1 \\
2 \\
3 \\
4 \\
5 \\
6 \\
7\end{array}$ & $\begin{array}{c}\star 9,600 \\
\star 6,400 \\
* 4,800 \\
\text { figure } 44 \\
\text { figure } 45 \\
\text { figure } 46 \\
\text { NA }\end{array}$ & $\begin{array}{c}\star 80 \\
\star 80 \\
\star 80 \\
T \text { for node } / 60 \\
T \text { for node } / 40 \\
T \text { for node } / 30 \\
\text { figure } 47\end{array}$ & 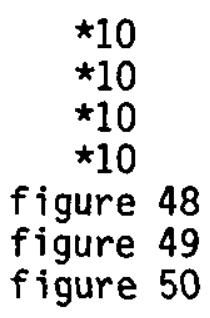 \\
\hline TRURO & $\begin{array}{l}1 \\
2 \\
3 \\
4 \\
5 \\
6 \\
7\end{array}$ & $\begin{array}{c}\star 10,800 \\
\star 7,200 \\
\star 5,400 \\
\star 7,200 \\
\text { figure } 51 \\
\text { figure } 52 \\
\text { NA }\end{array}$ & $\begin{array}{c}\star 90 \\
\star 90 \\
\star 90 \\
\star 120 \\
T \text { for node } / 40 \\
T \text { for node } / 30 \\
\text { figure } 53\end{array}$ & $\begin{array}{r}\star 10 \\
\star 10 \\
\star 10 \\
\star 10 \\
\text { figure } 54 \\
\text { figure } 55 \\
\star 10\end{array}$ \\
\hline
\end{tabular}

TK arrays, ESTHM, layers 1-2, 2-3, and 3-4 were multiplied by 0.45 . TK array, WLFLT, layers 3-4 was multiplied by 0.89 .

TK arrays, TRURO, layers 1-2, 2-3, and 3-4 were multiplied by 0.9 . 


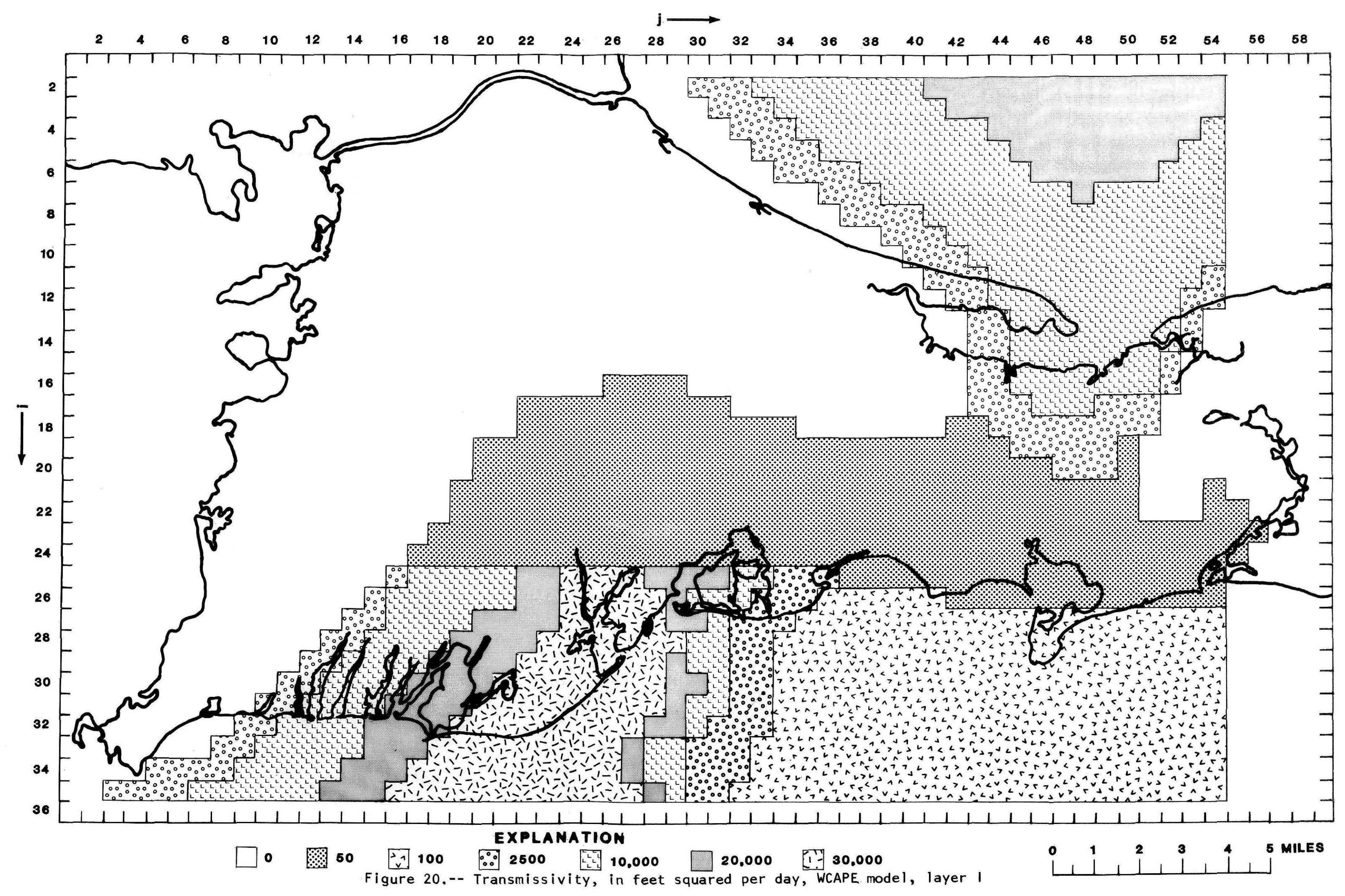




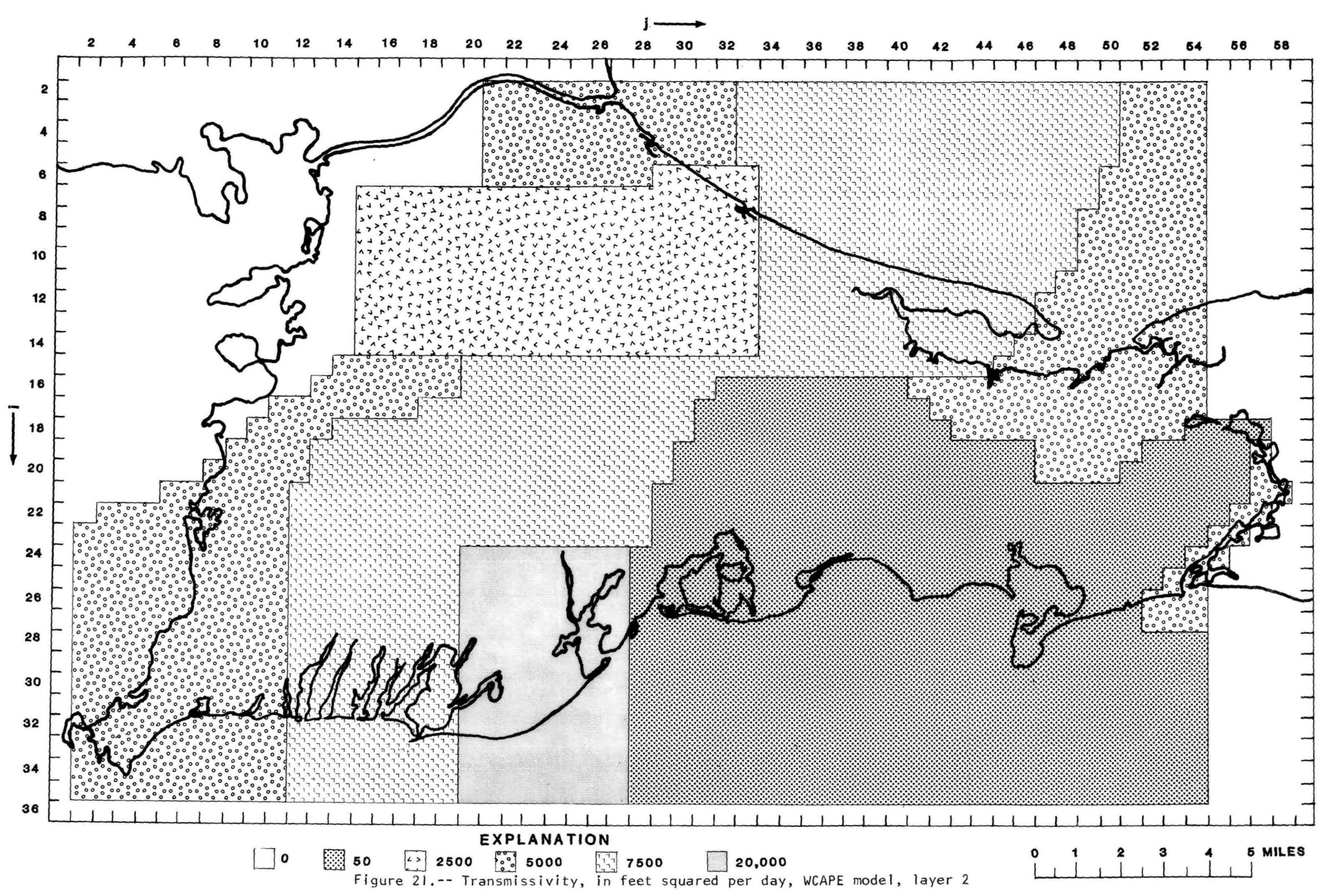




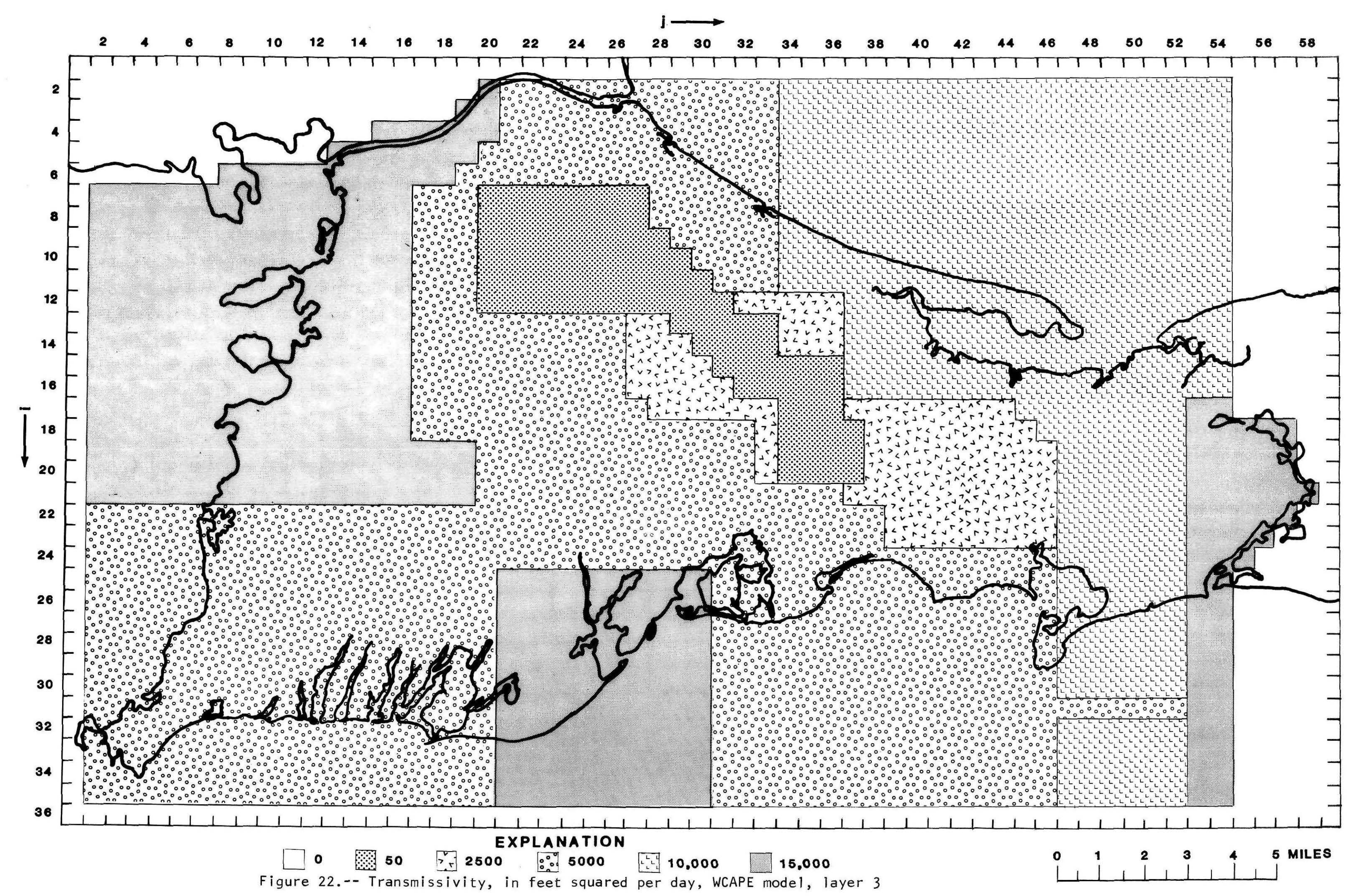




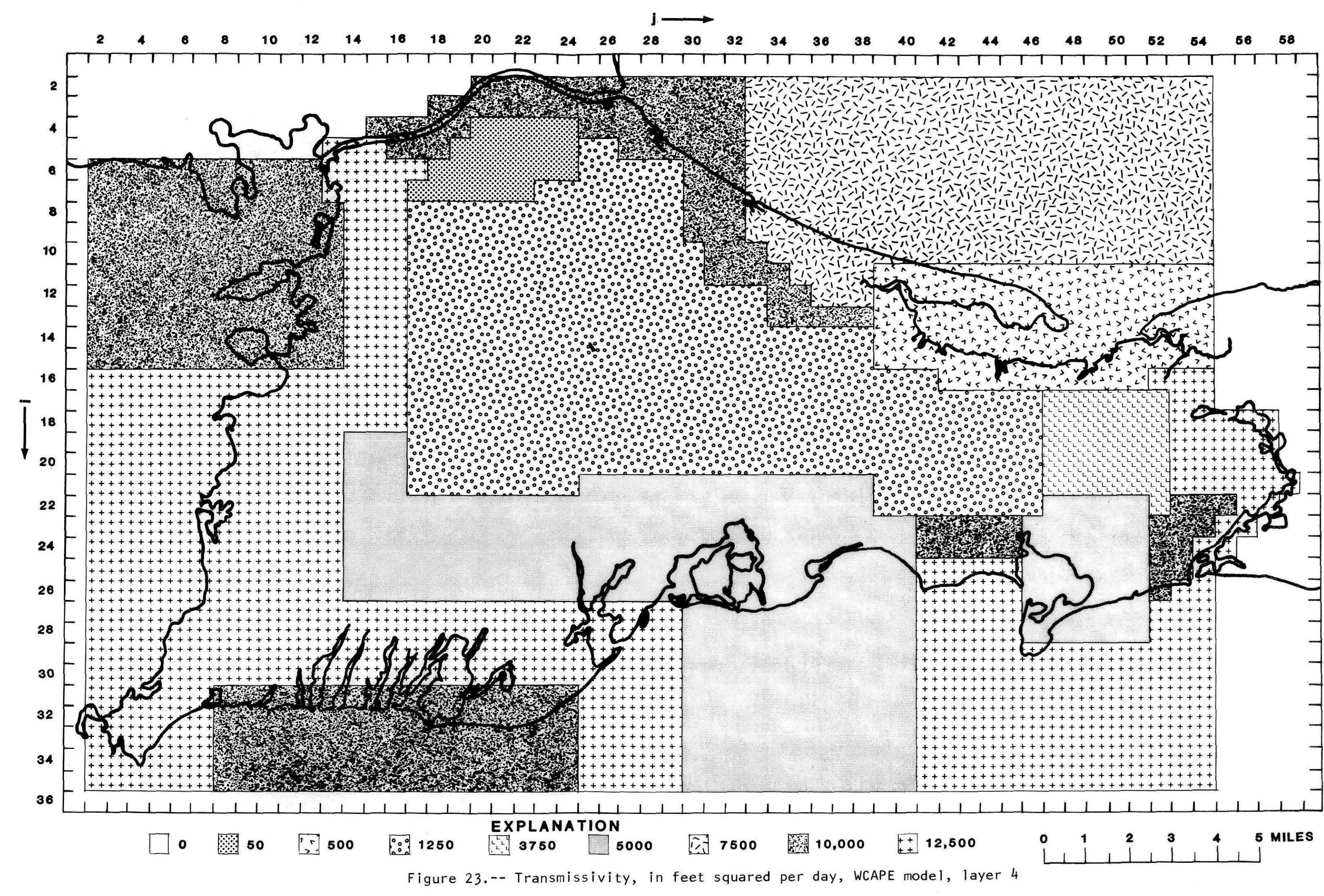




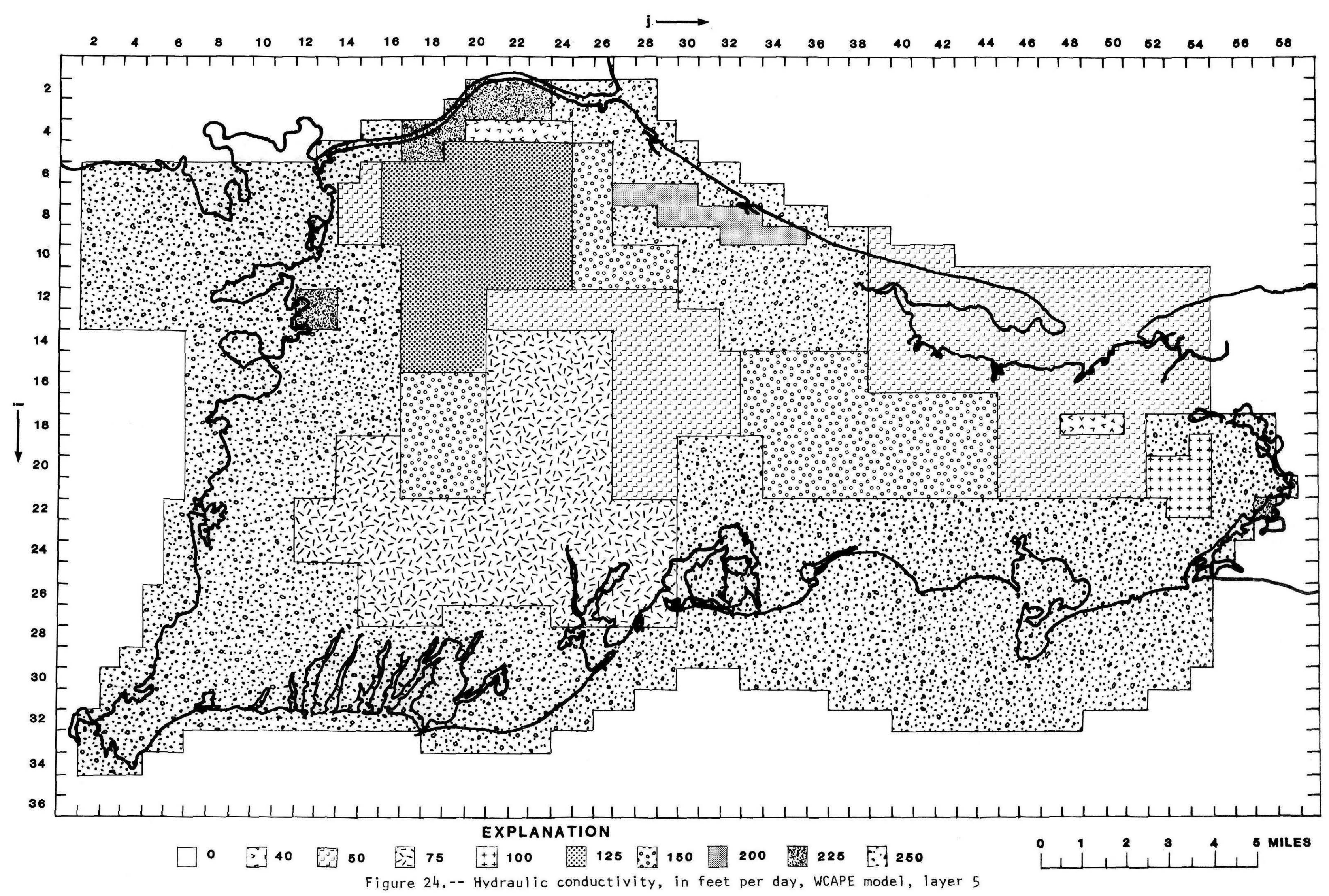




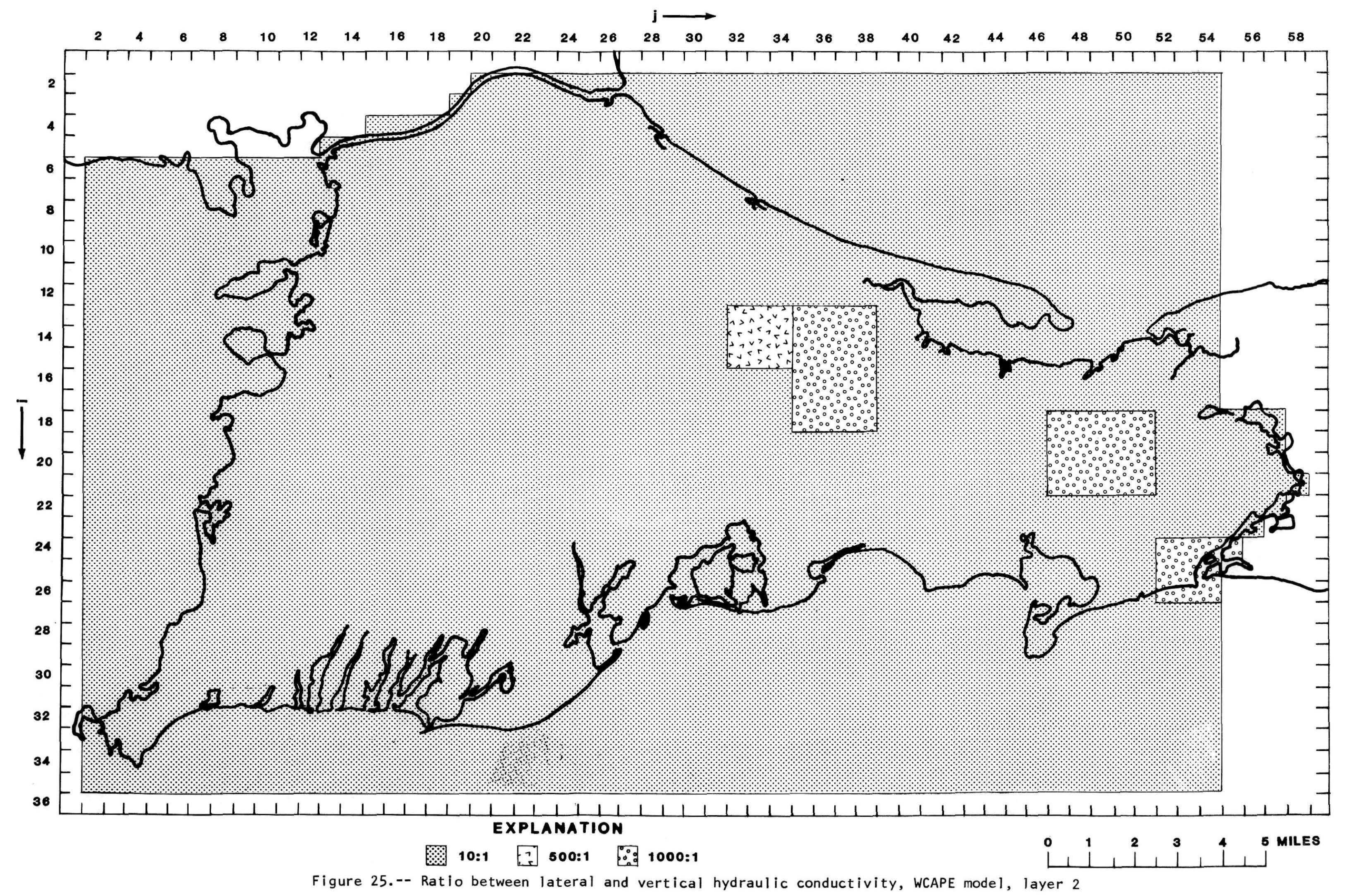




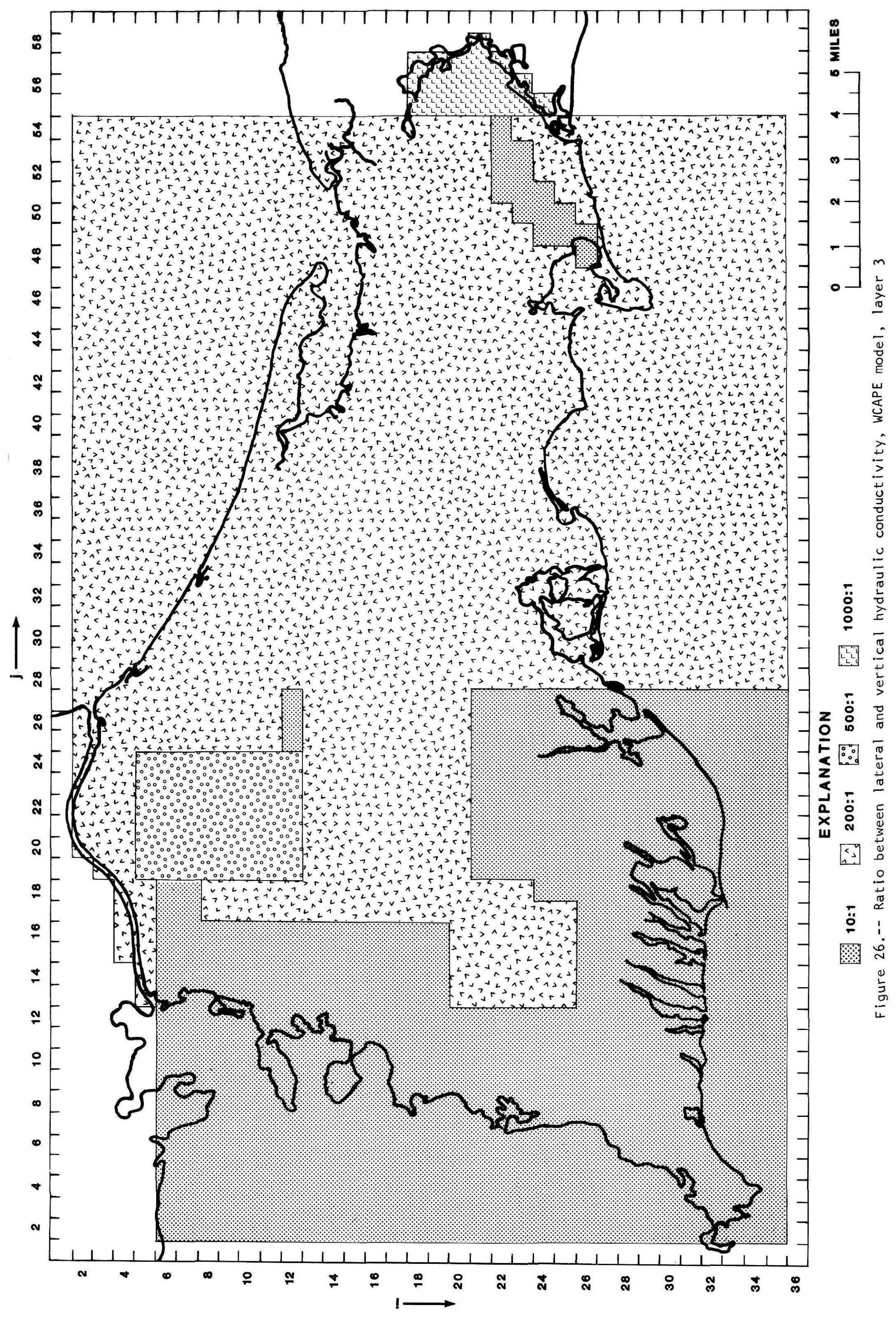




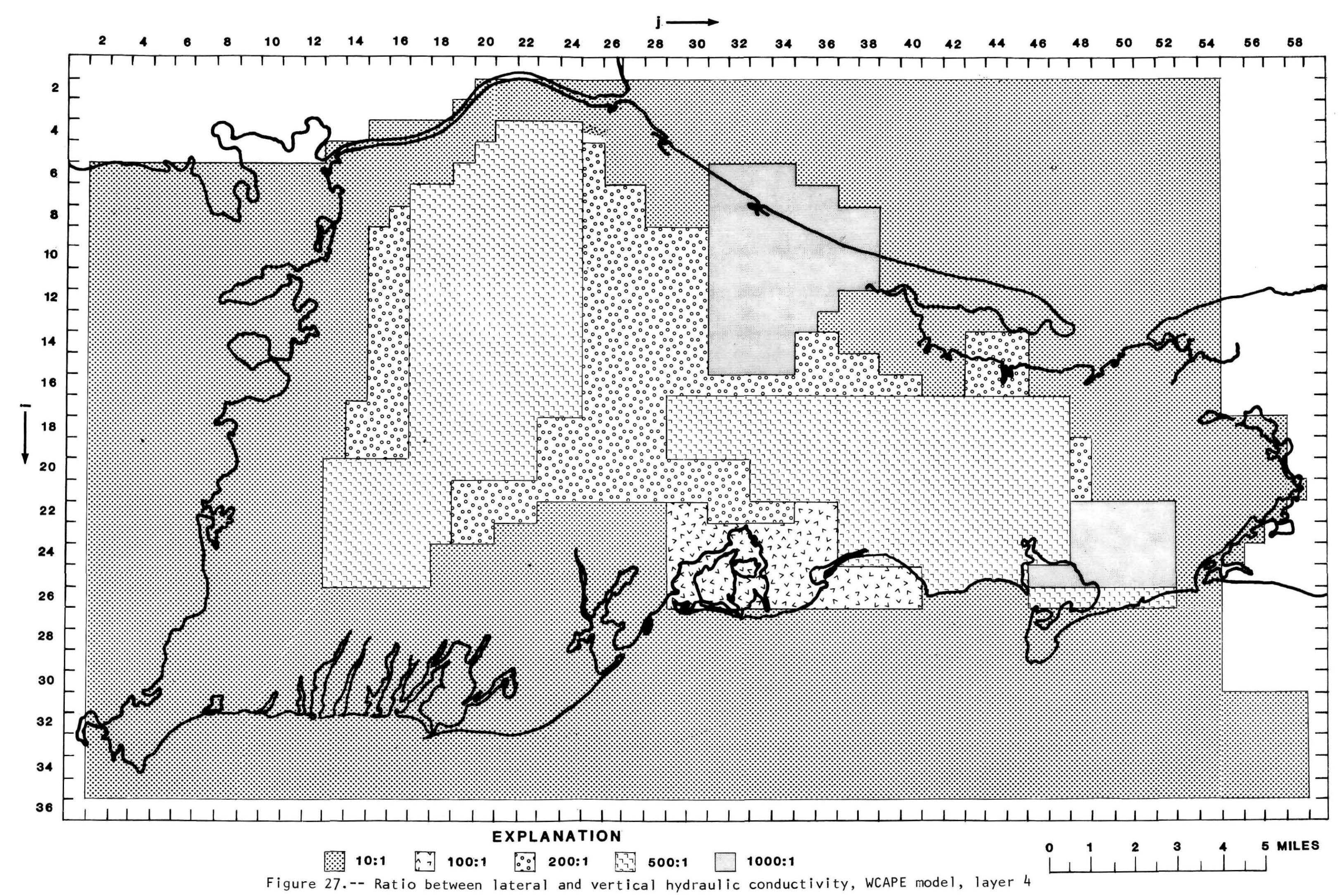




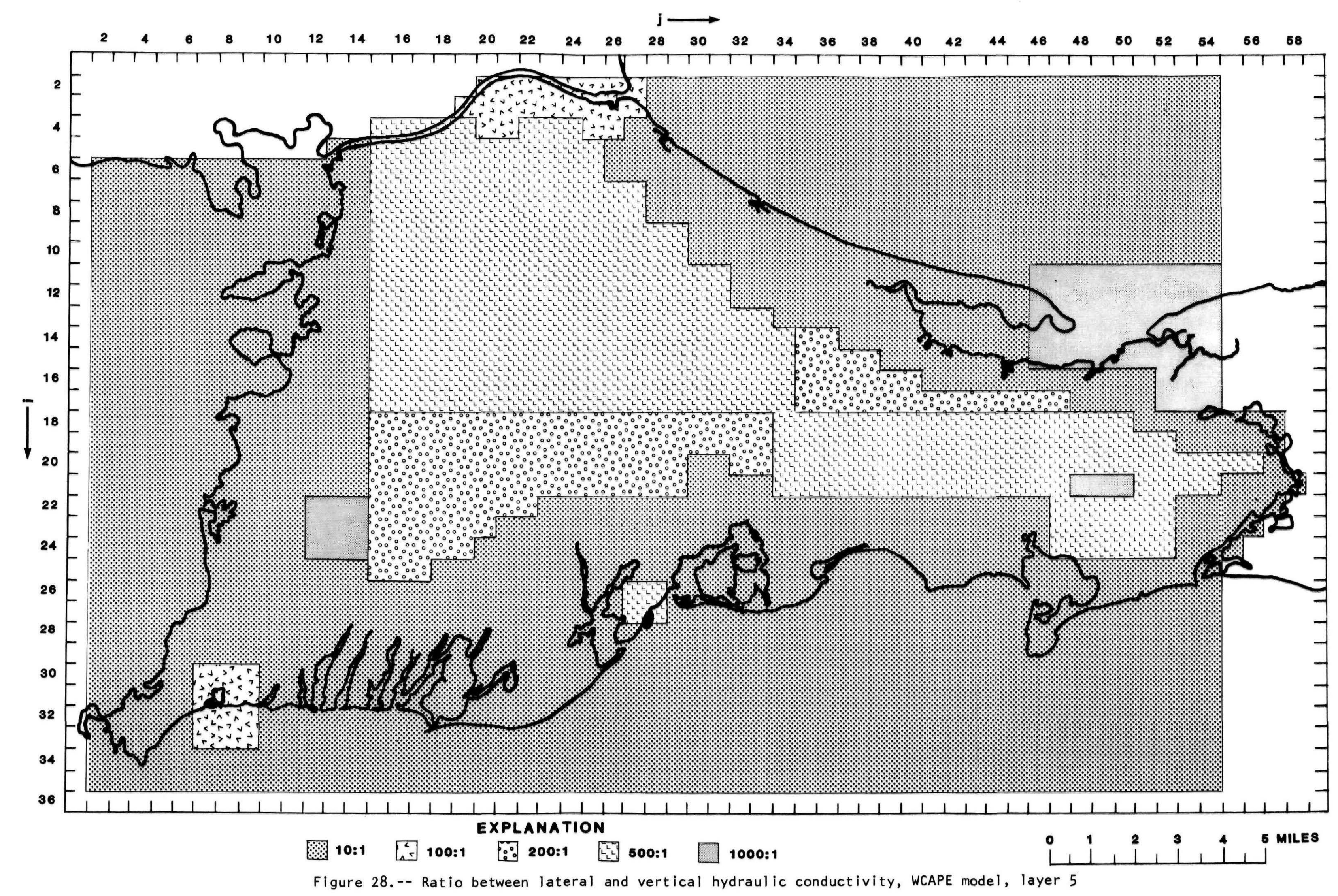




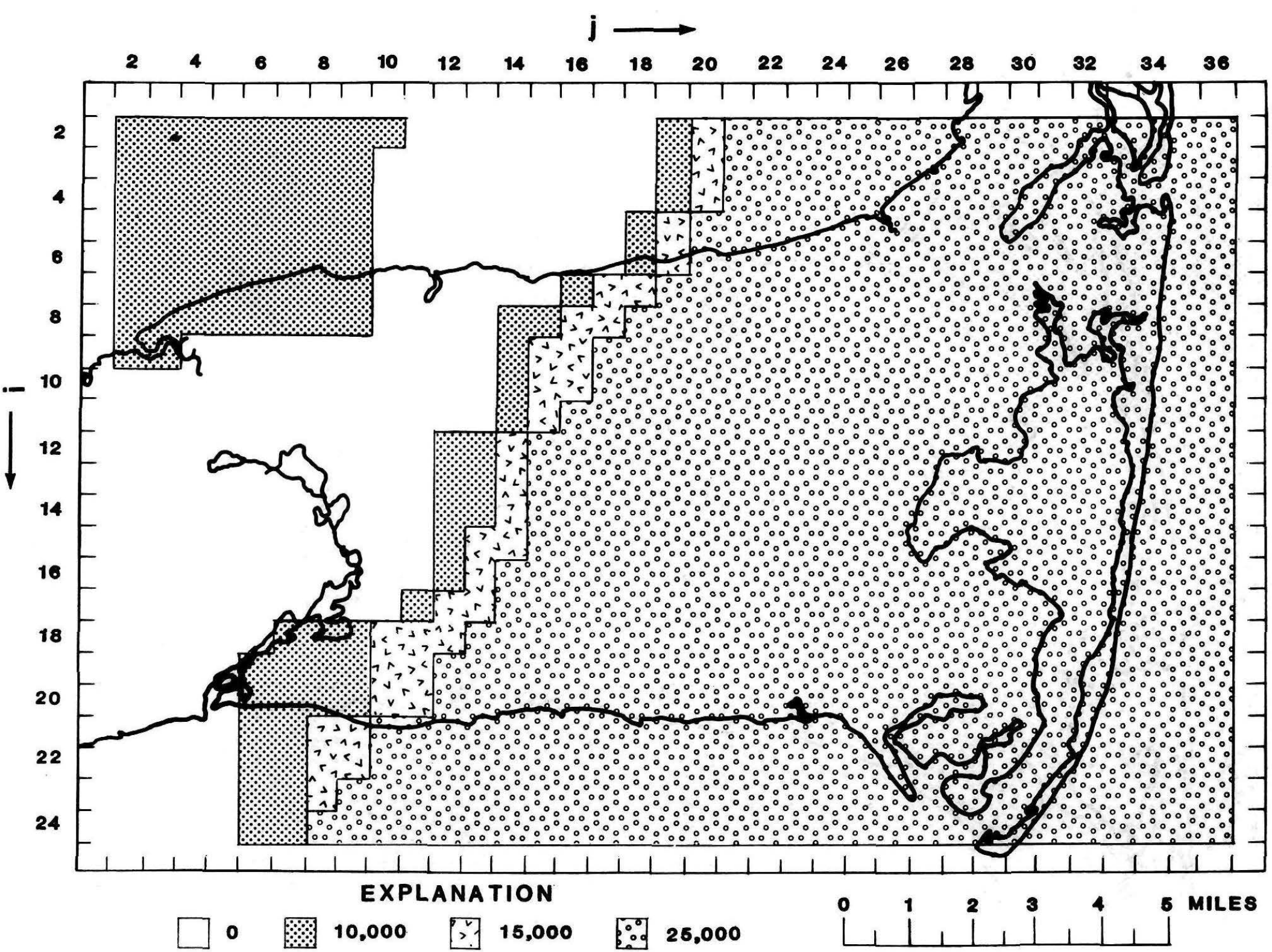

Figure 29.-- Transmissivity, in feet squared per day, ECAPE model, layer 1 


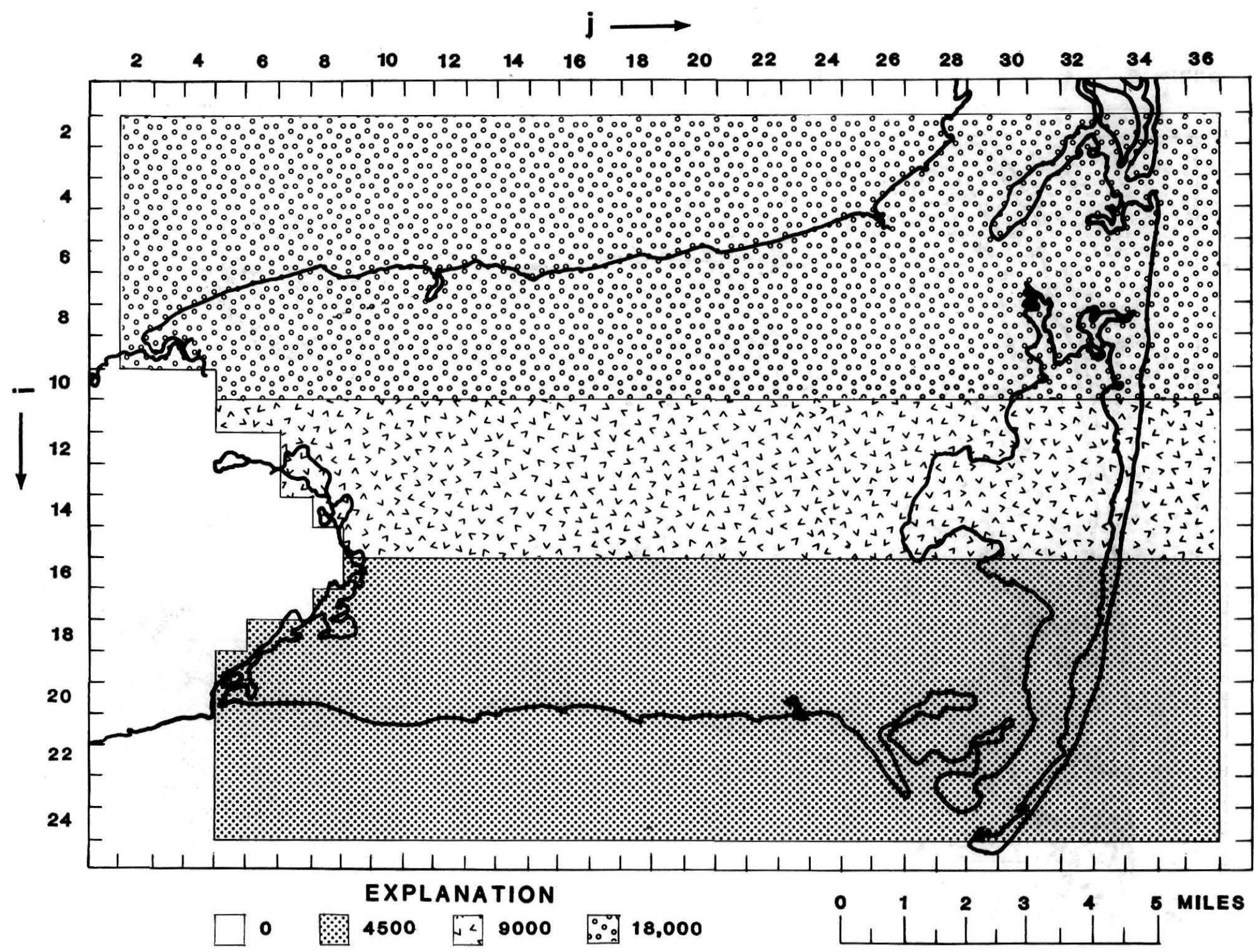

Figure 30.-- Transmissivity, in feet squared per day, ECAPE model, layer 2 


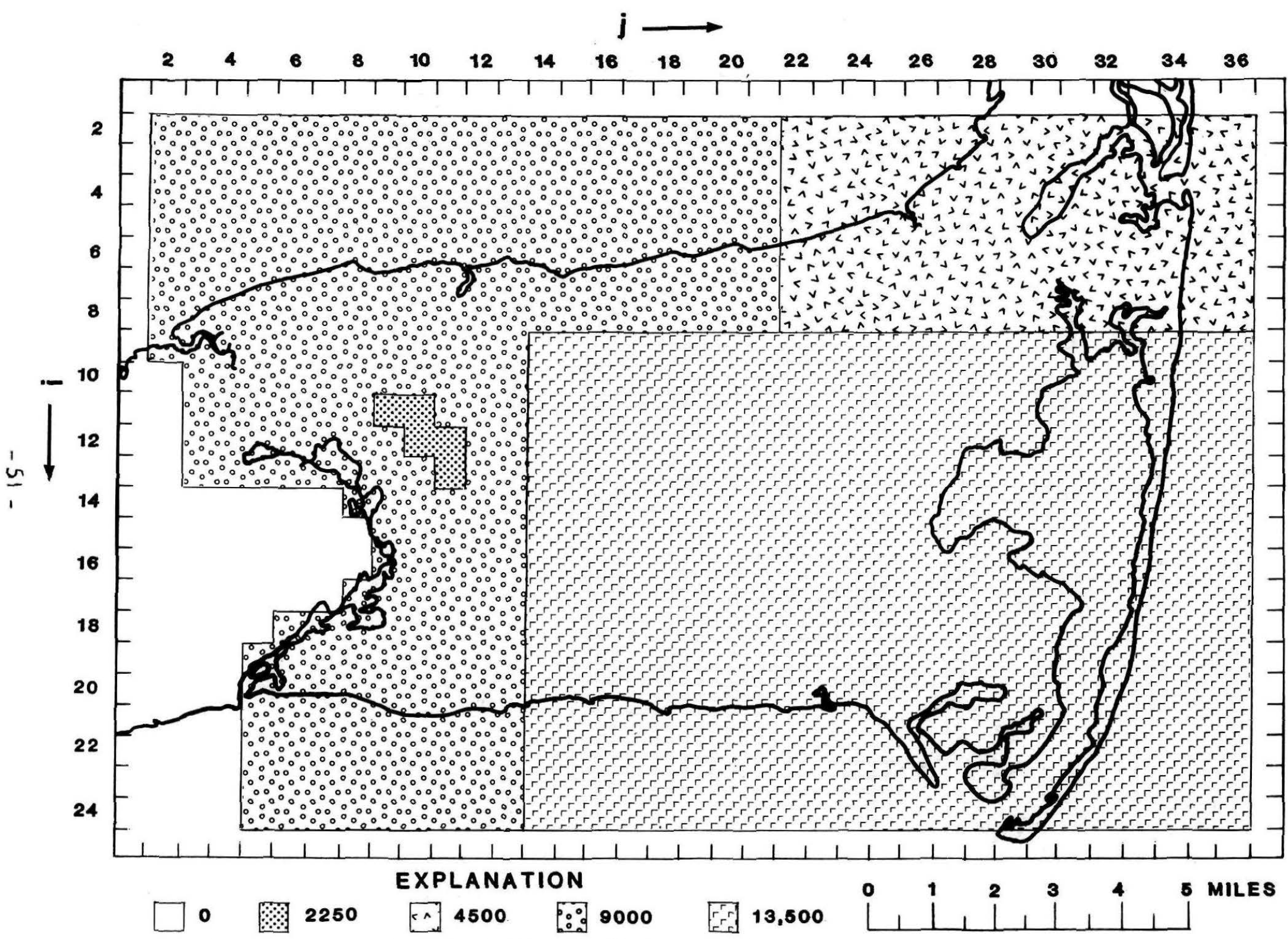

Figure 31.-- Transmissivity, in feet squared per day, ECAPE model, layer 3 


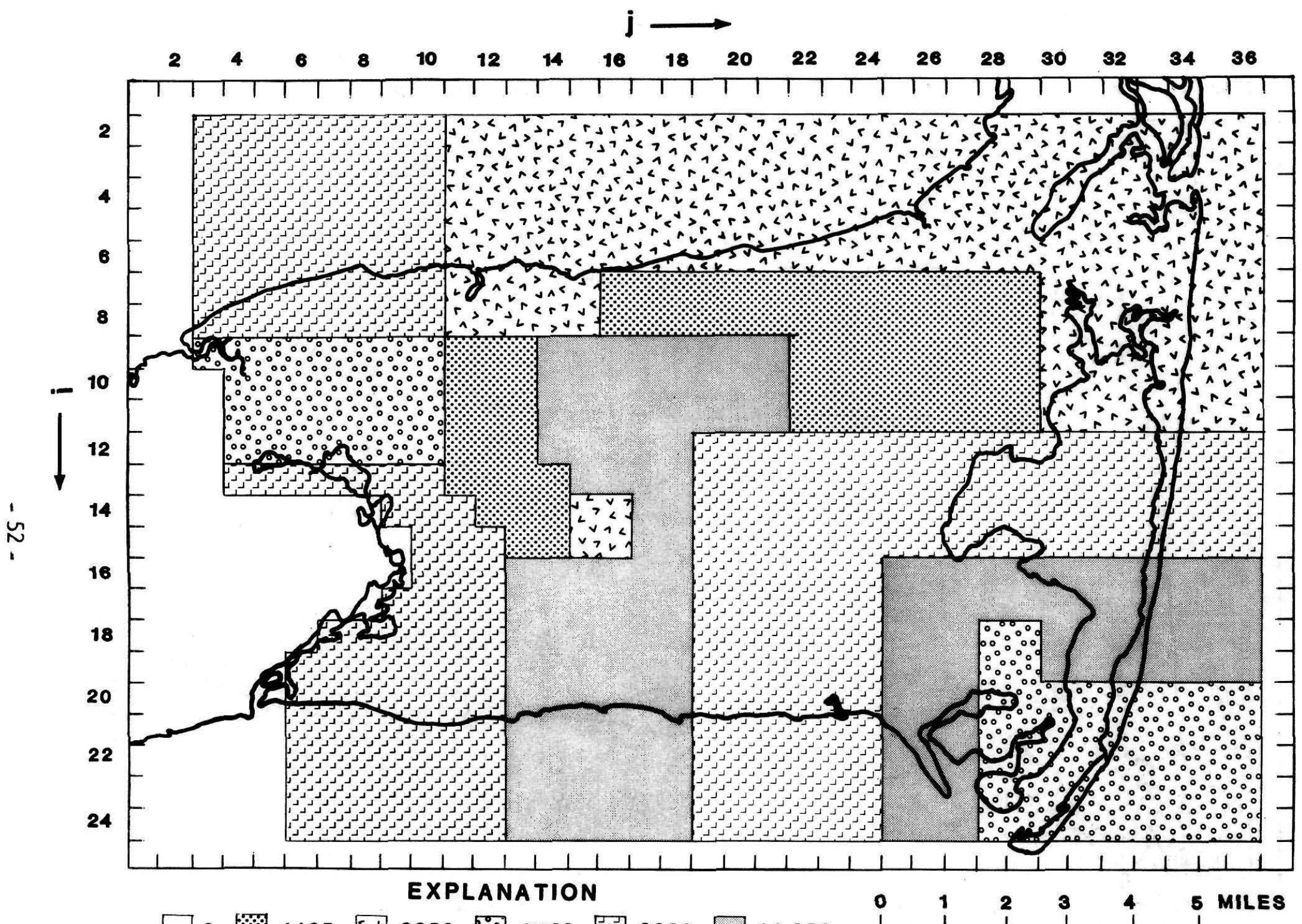

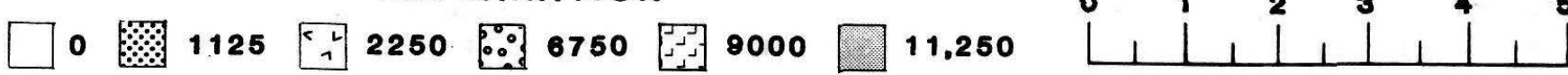

Figure 32.-- Transmissivity, in feet squared per day, ECAPE model, layer 4 


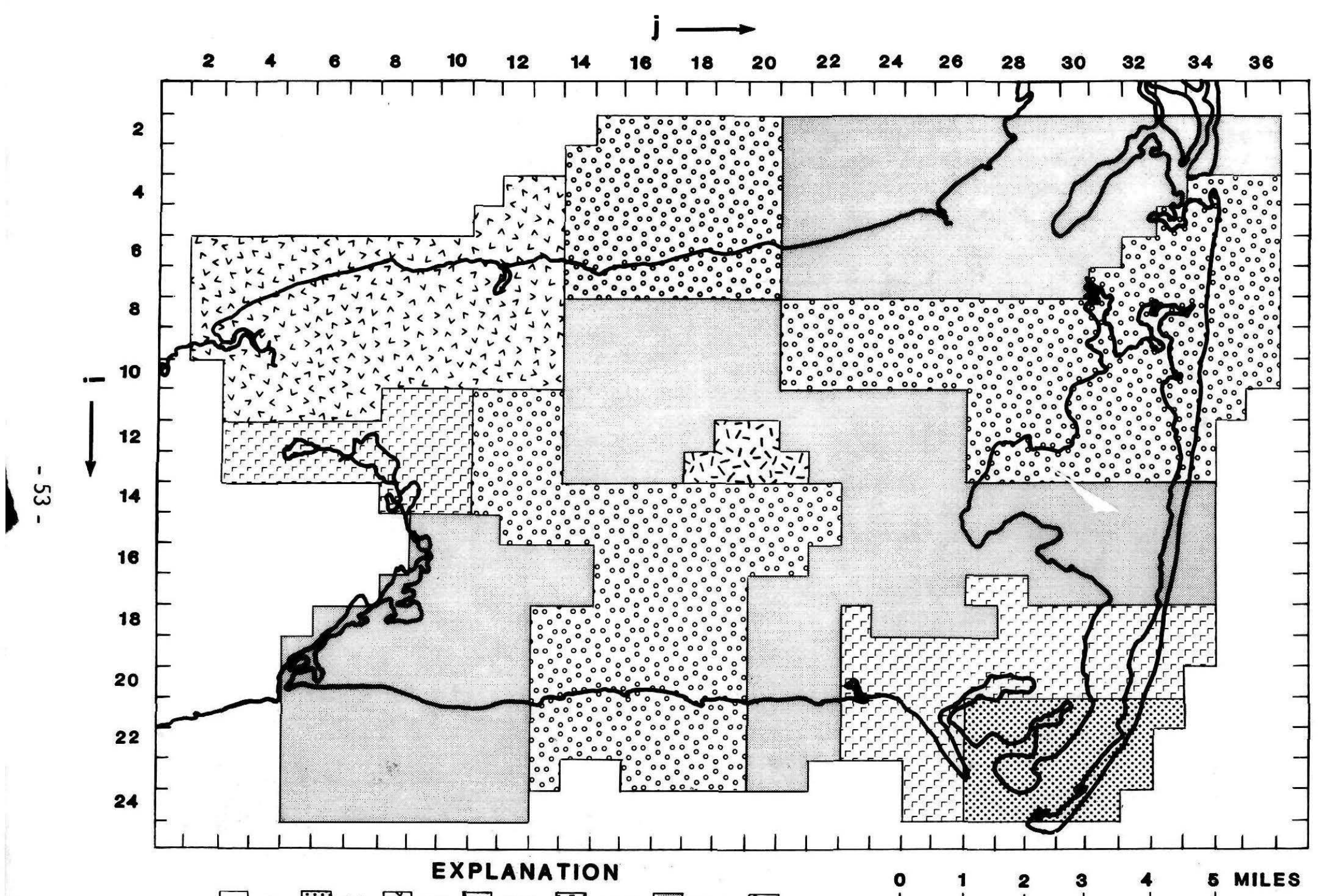

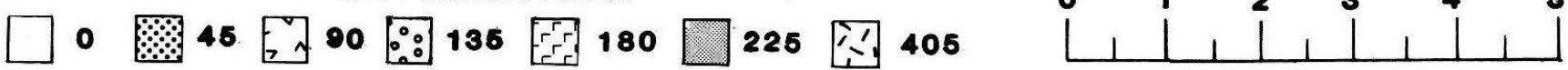

Figure 33.-- Hydraulic conductivity, in feet per day, ECAPE model, layer 5 


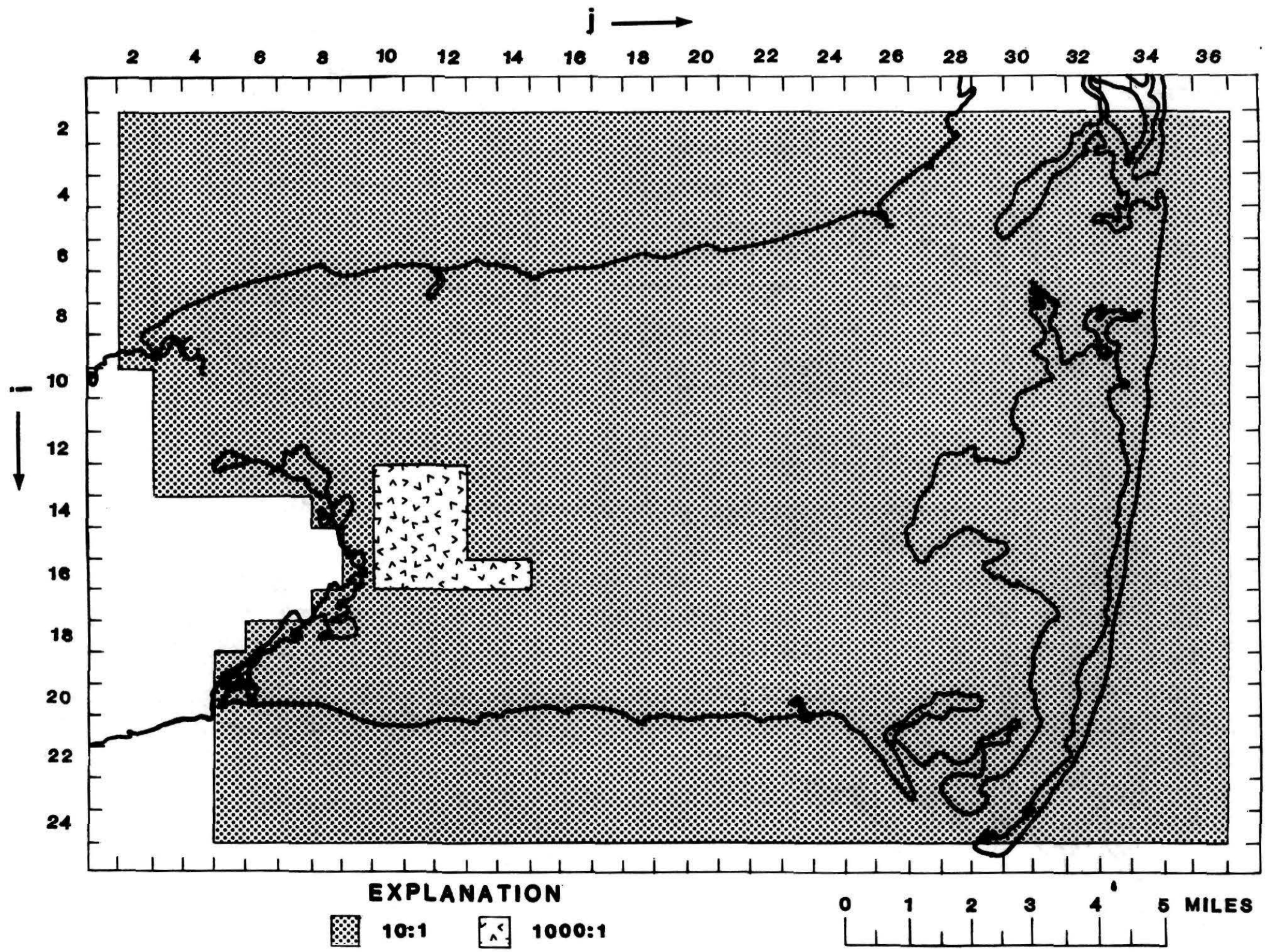

Figure 34.-- Ratio between lateral and vertical hydraulic conductivity, ECAPE model, layer 2 


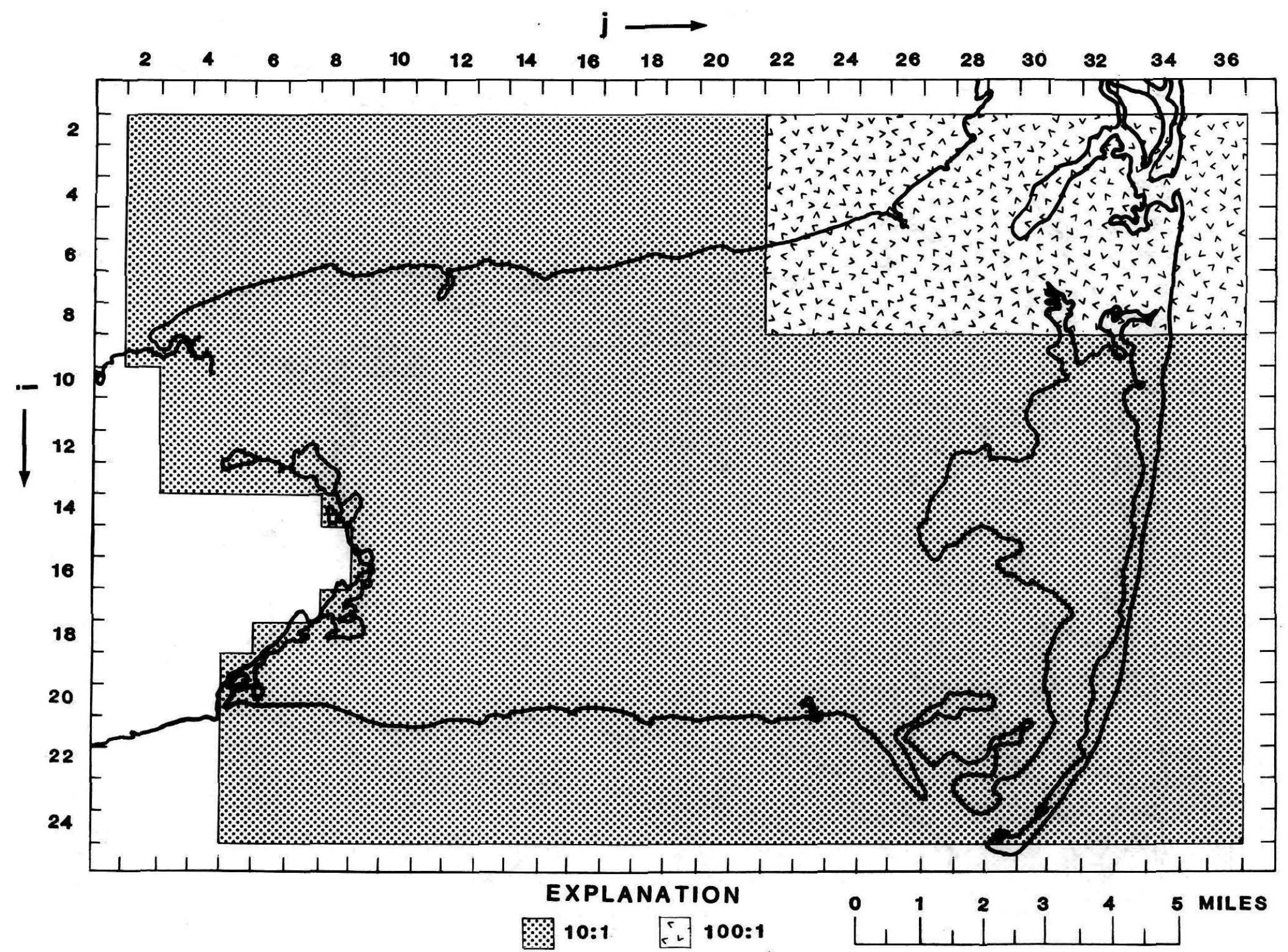

Figure 35.-- Ratio between lateral and vertical hydraulic conductivity, ECAPE model, layer 3 


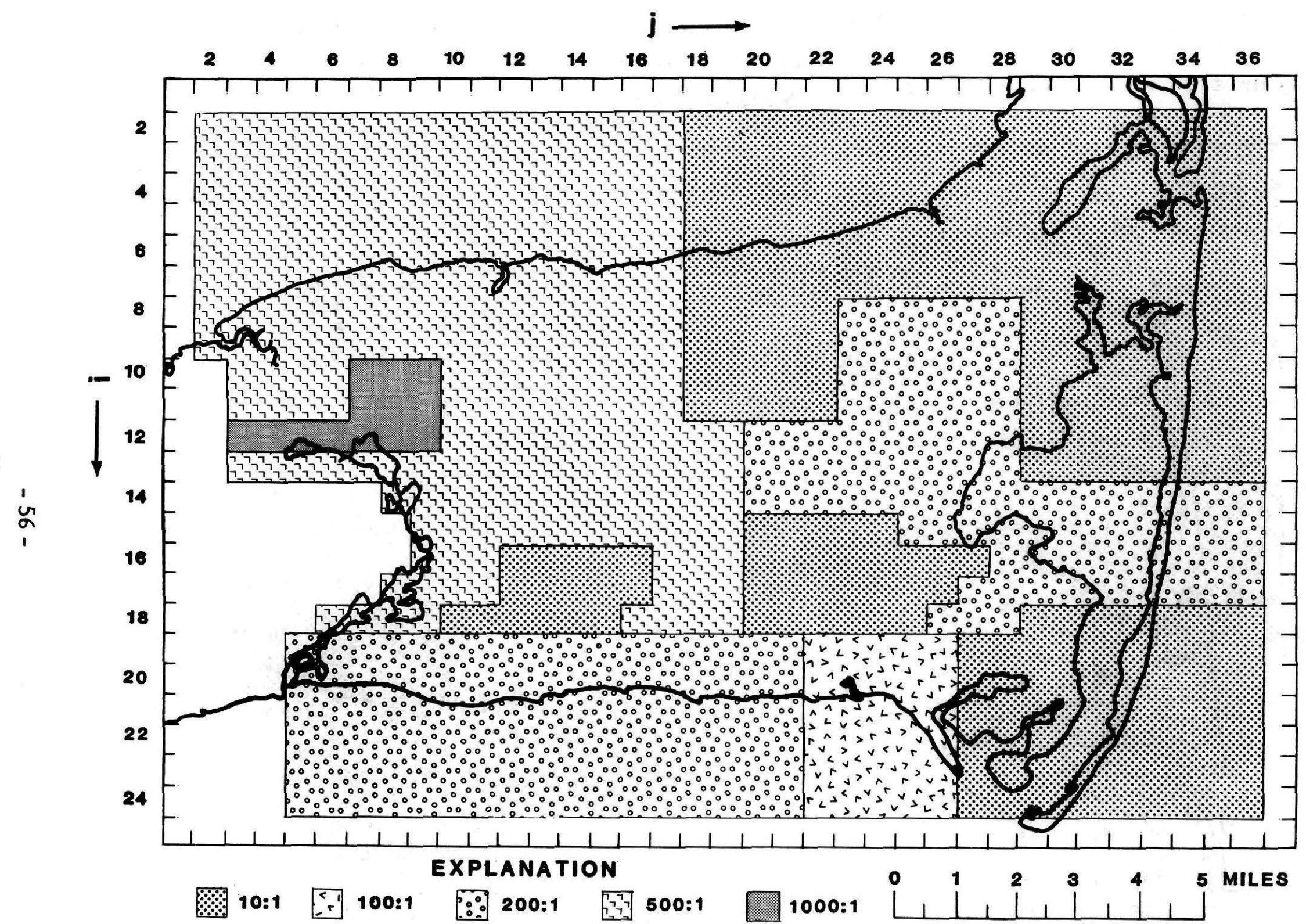

Figure 36.-- Ratio between lateral and vertical hydraulic conductivity, ECAPE model, layer 4 


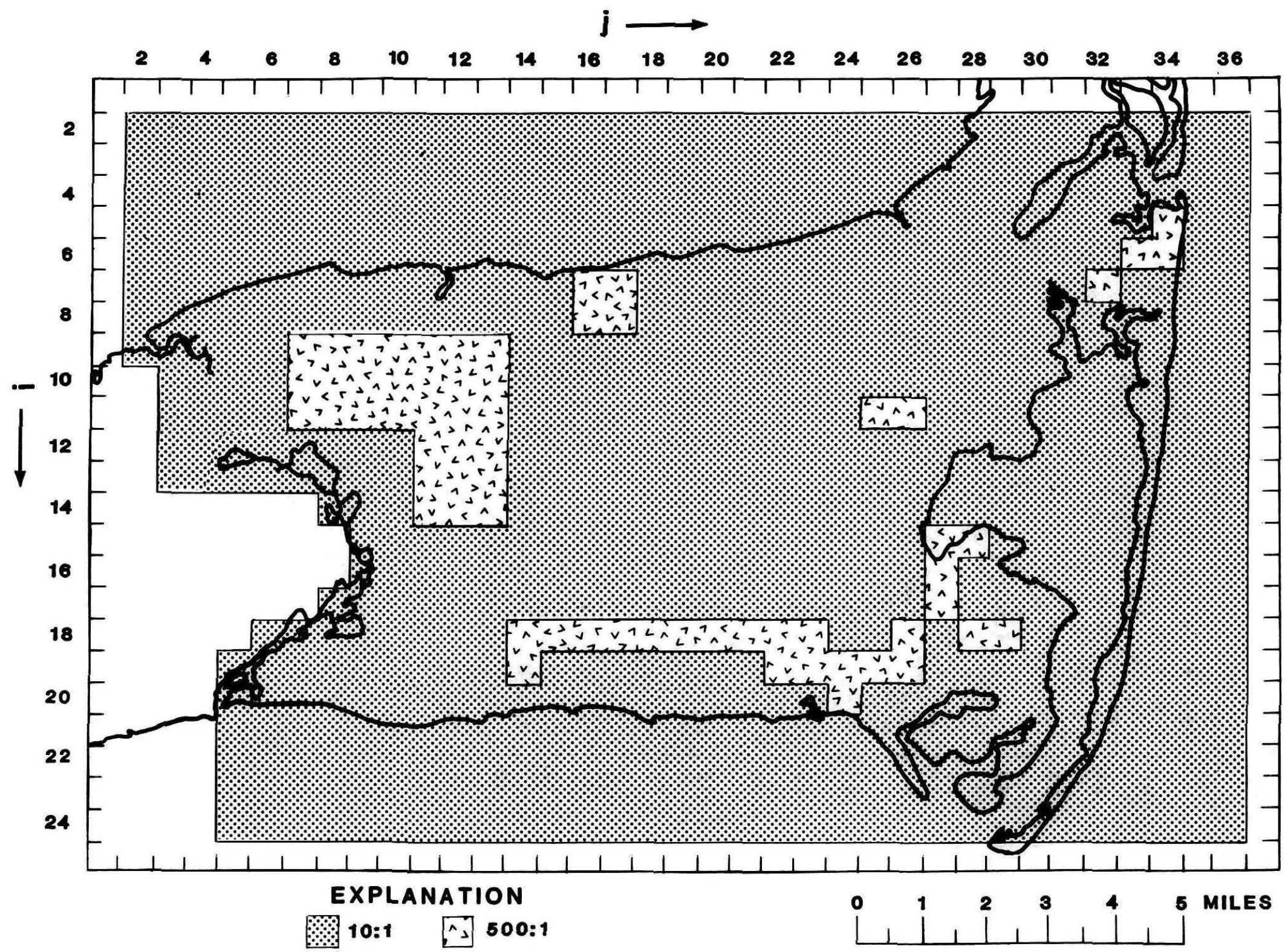

Figure 37.-- Ratio between lateral and vertical hydraulic conductivity, ECAPE model, layer 5 


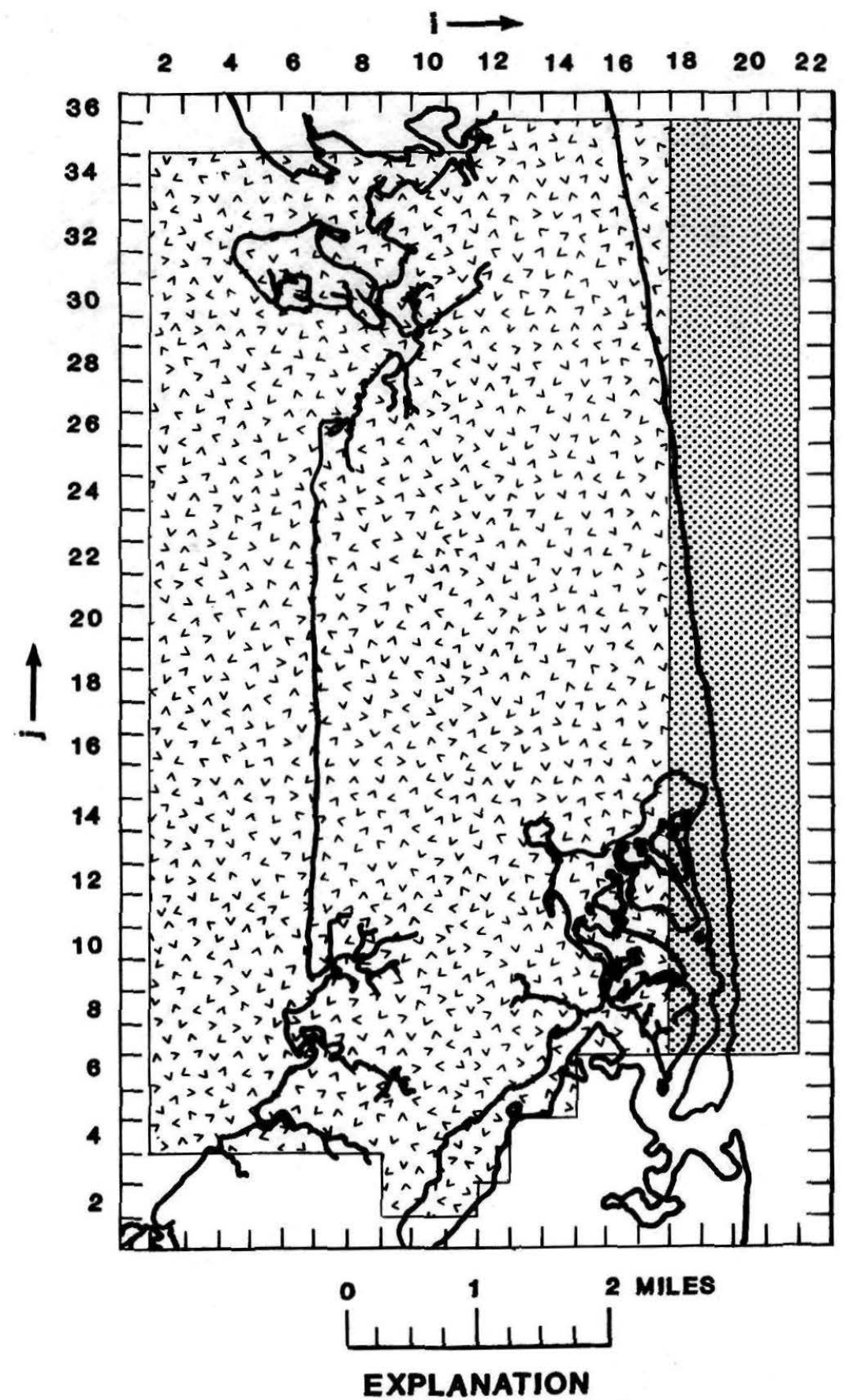

Figure 38.-- Transmissivity, in feet squared per day, ESTHM model, layer 5 


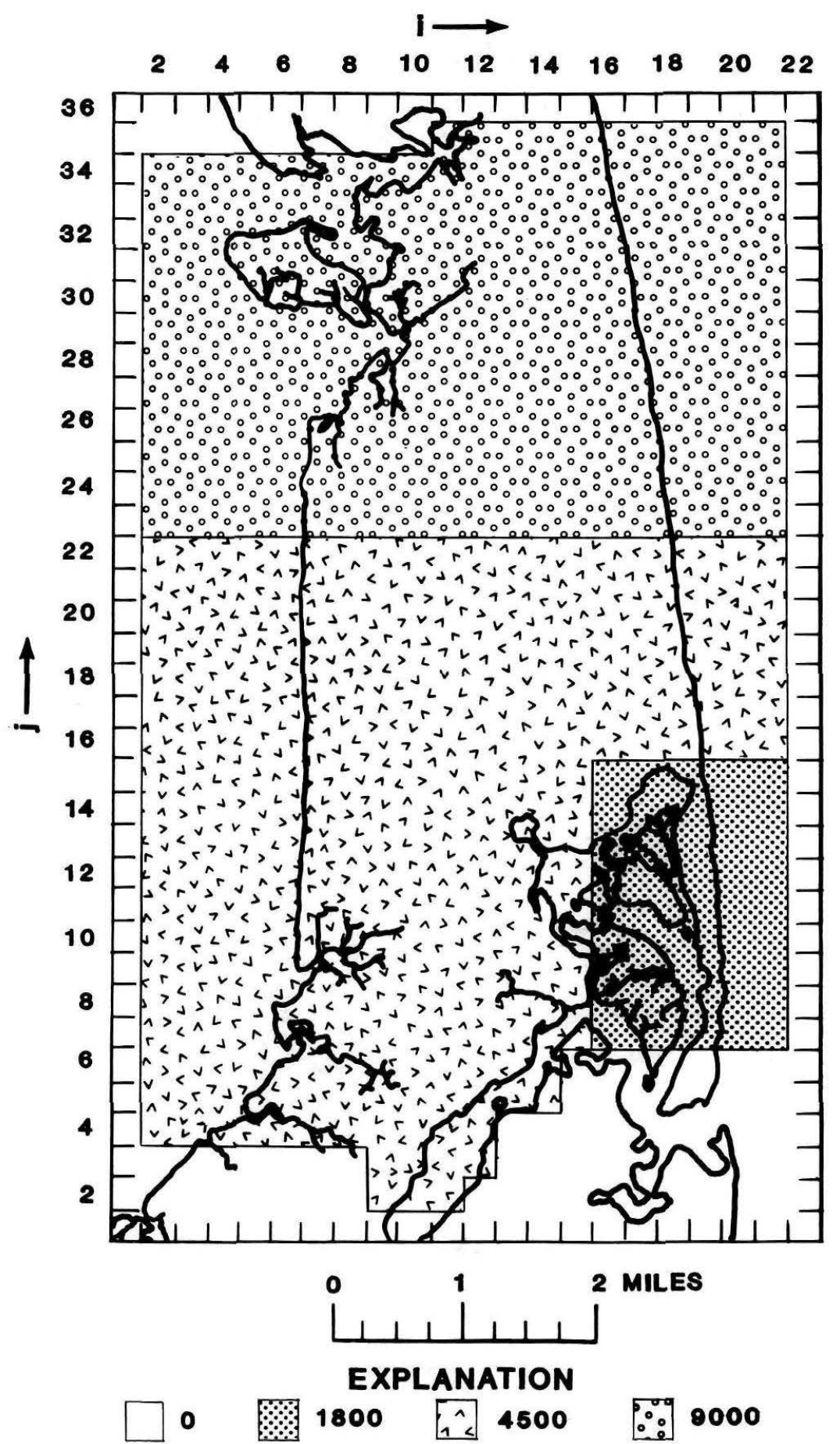

Figure 39.-- Transmissivity, in feet squared per day, ESTHM model, layer 6 


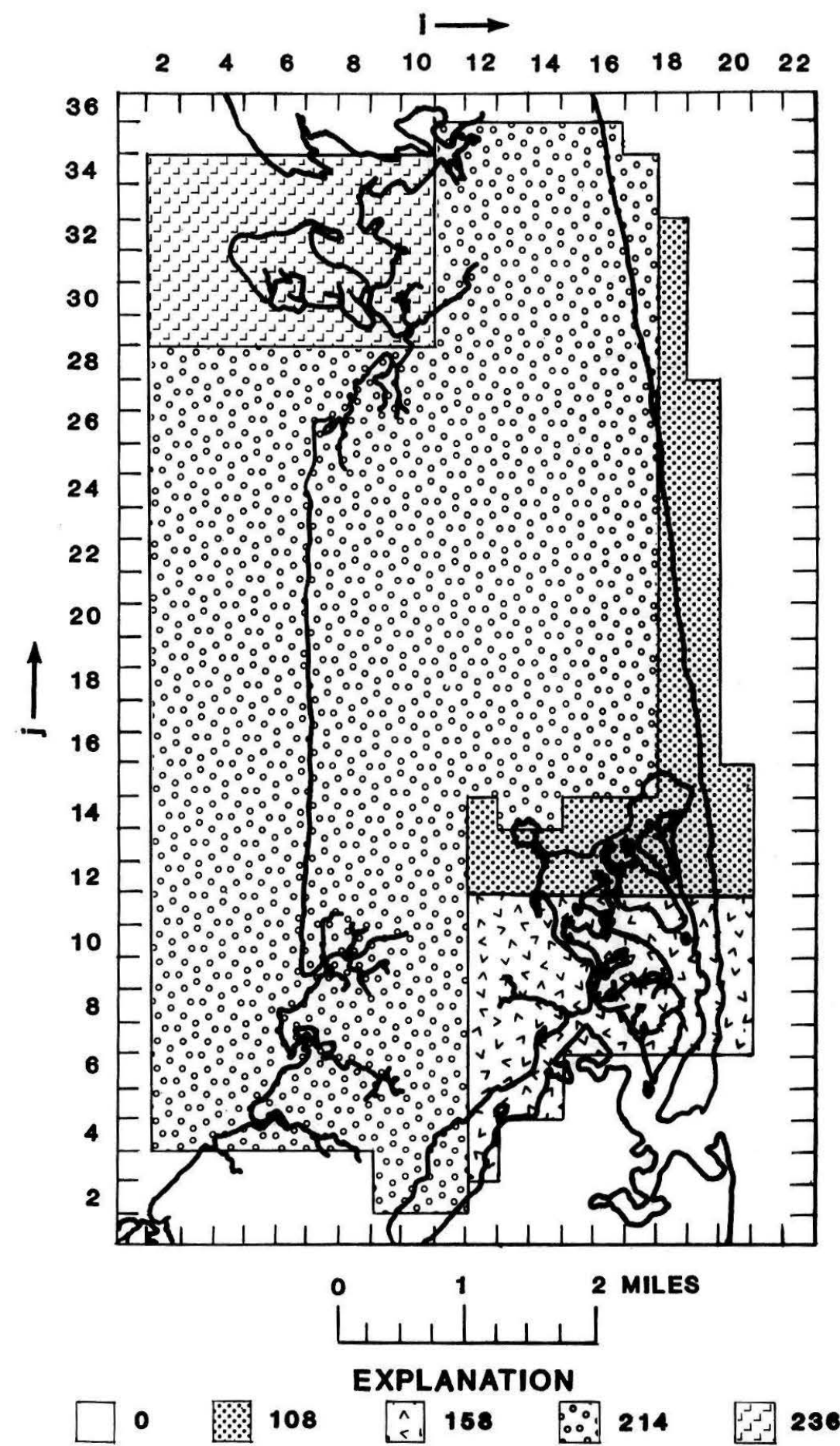

Figure 40.-- Hydraulic conductivity, in feet per day, ESTHM model, layer 7 


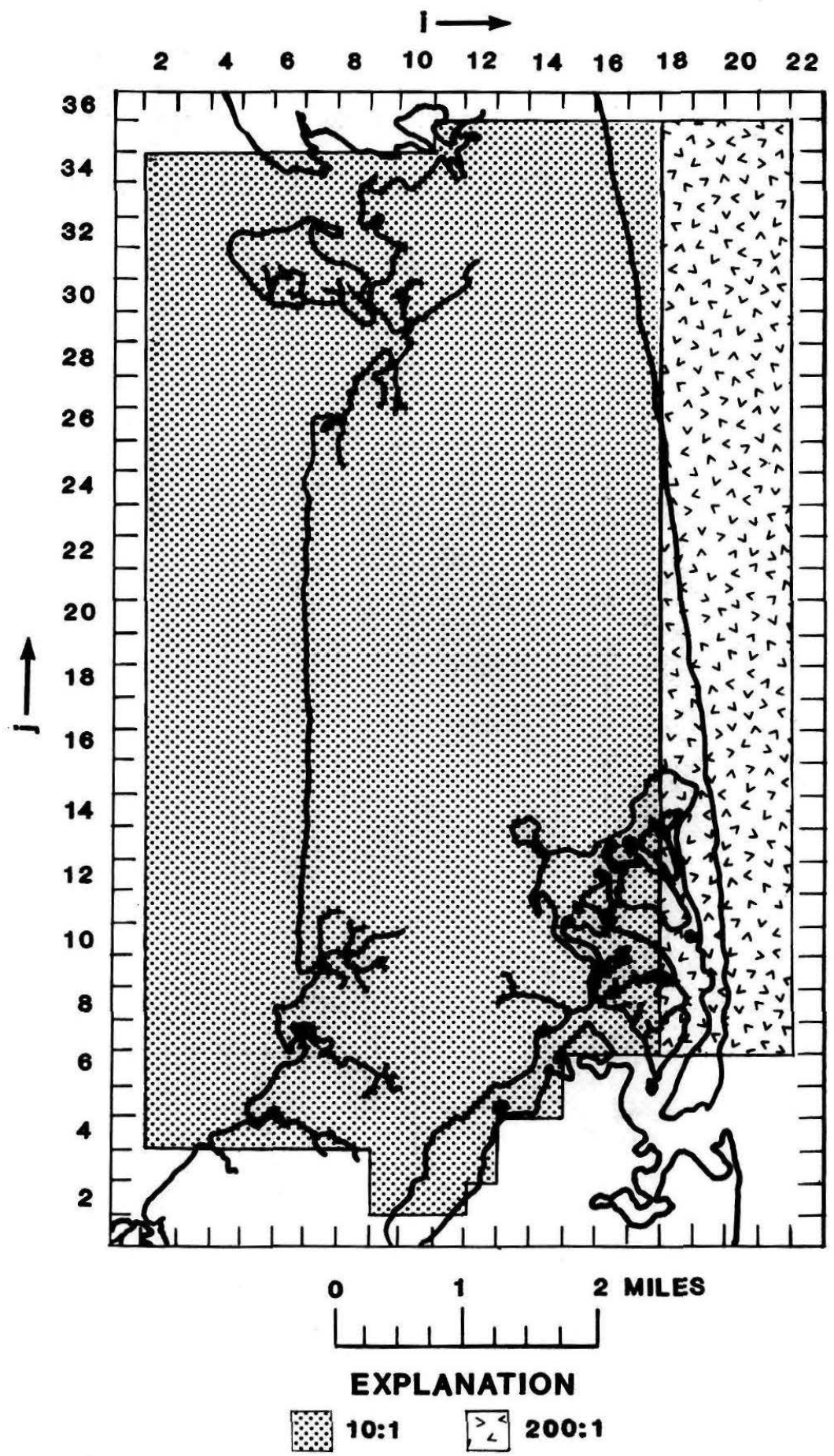

Figure 41.-- Ratio between lateral and vertical hydraulic conductivity, ESTHM model, layer 5 


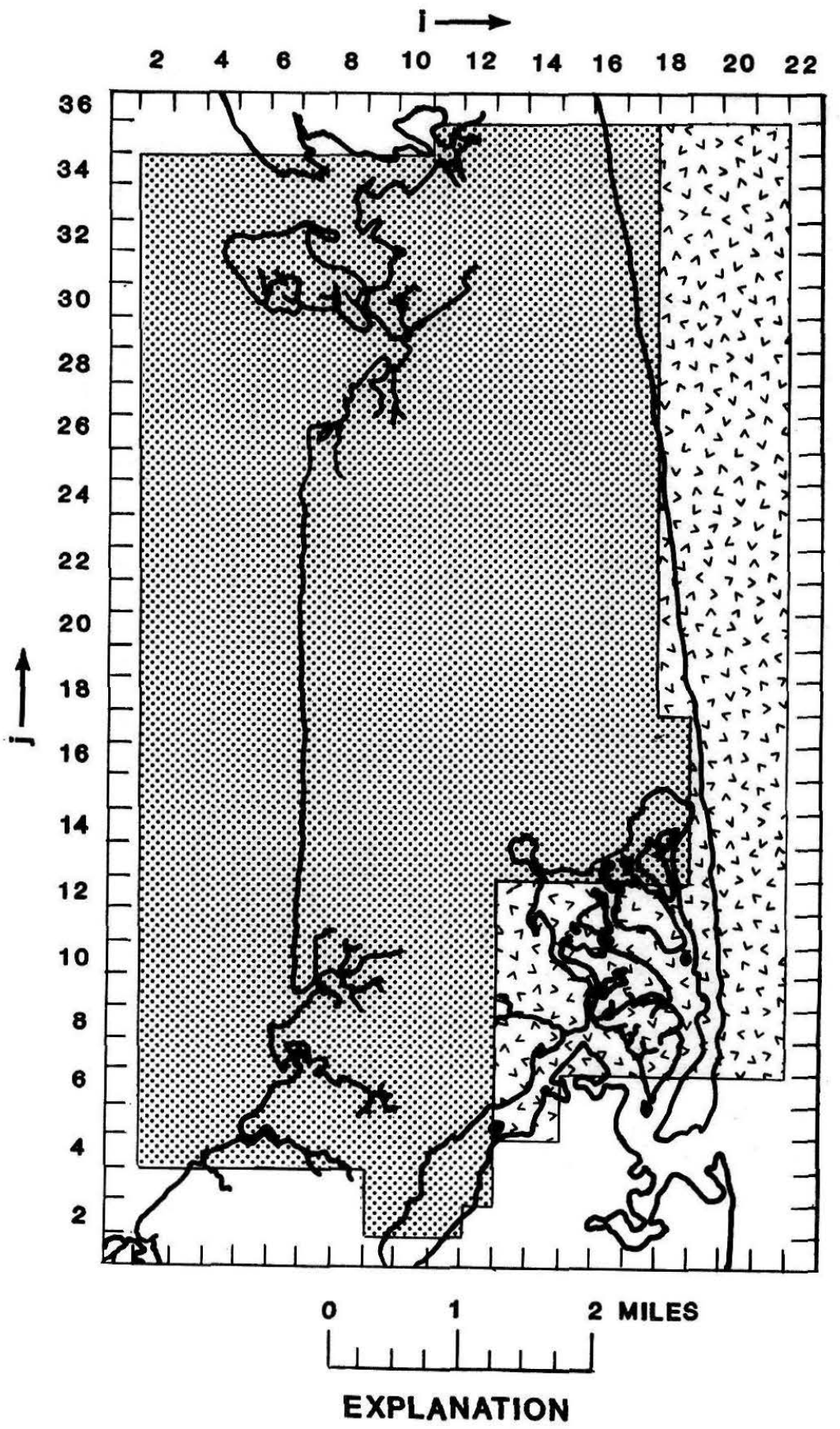

10:1 $20: 1$

Figure 42.-- Ratio between lateral and vertical hydraulic conductivity, ESTHM model, layer 6 

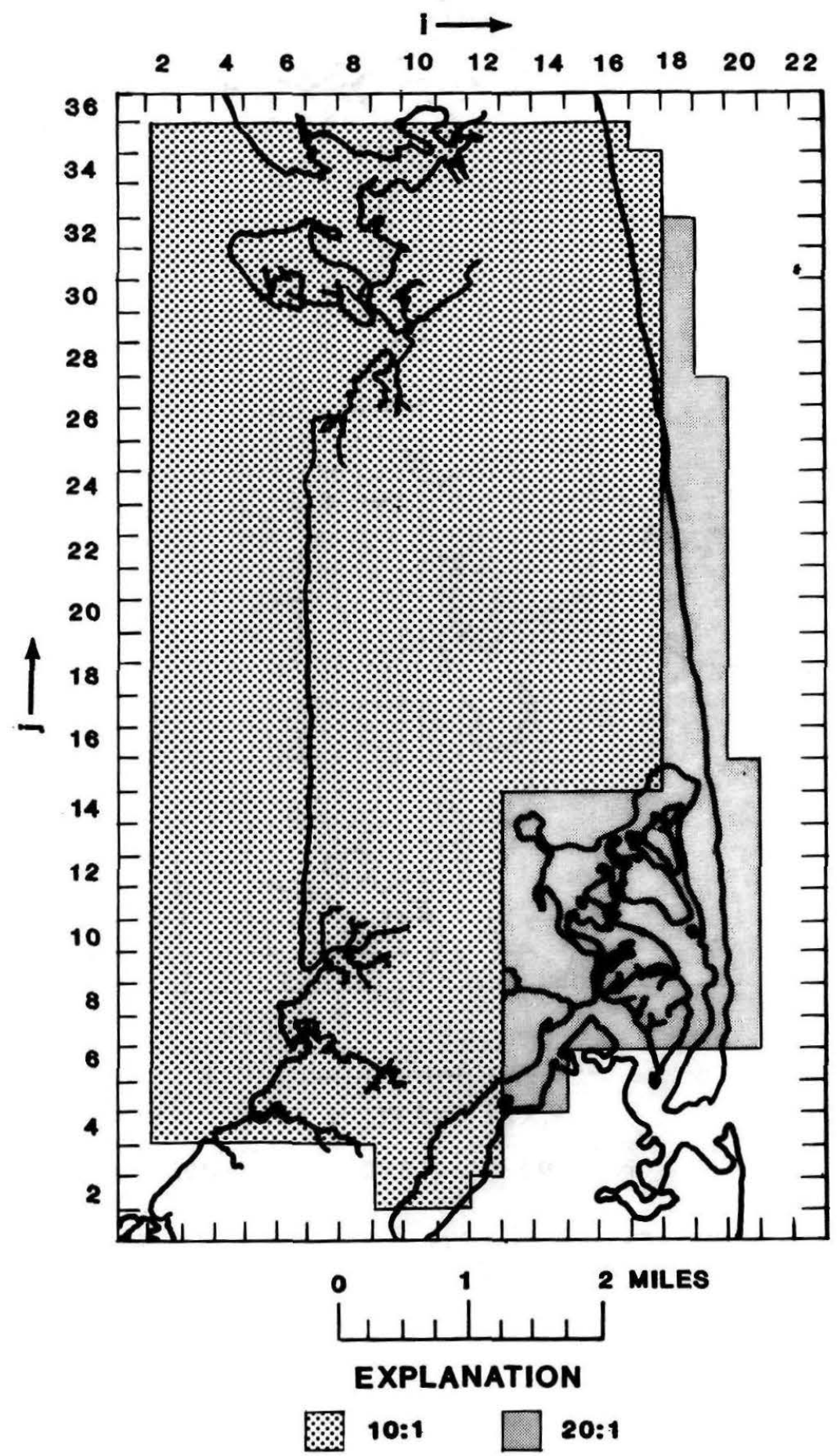

Figure 43.-- Ratio between lateral and vertical hydraulic conductivity, ESTHM model, layer 7 

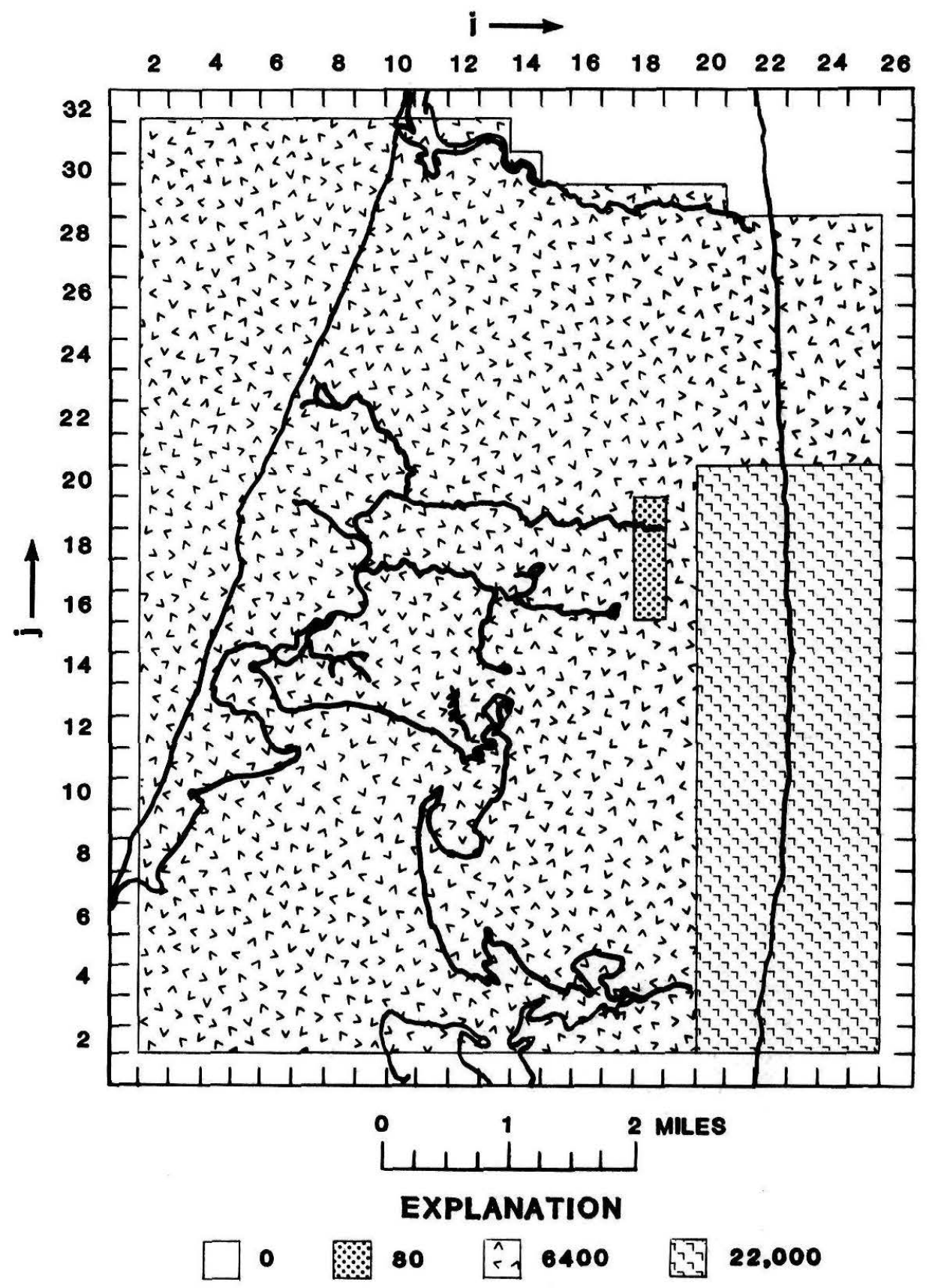

Figure 44.-- Transmissivity, in feet squared per day, WLFLT model, layer 4 

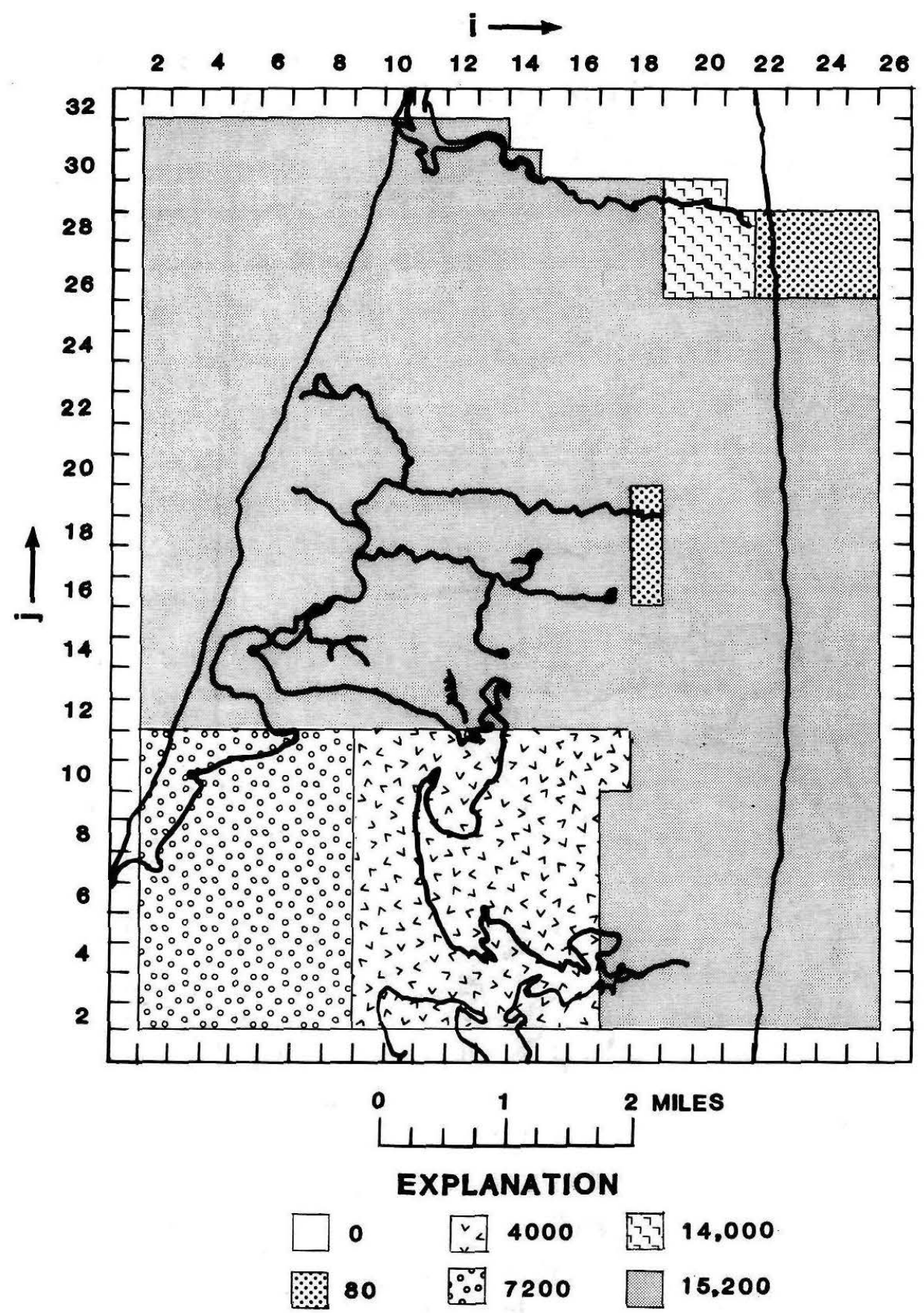

Figure 45.-- Transmissivity, in feet squared per day, WLFLT model, layer 5 


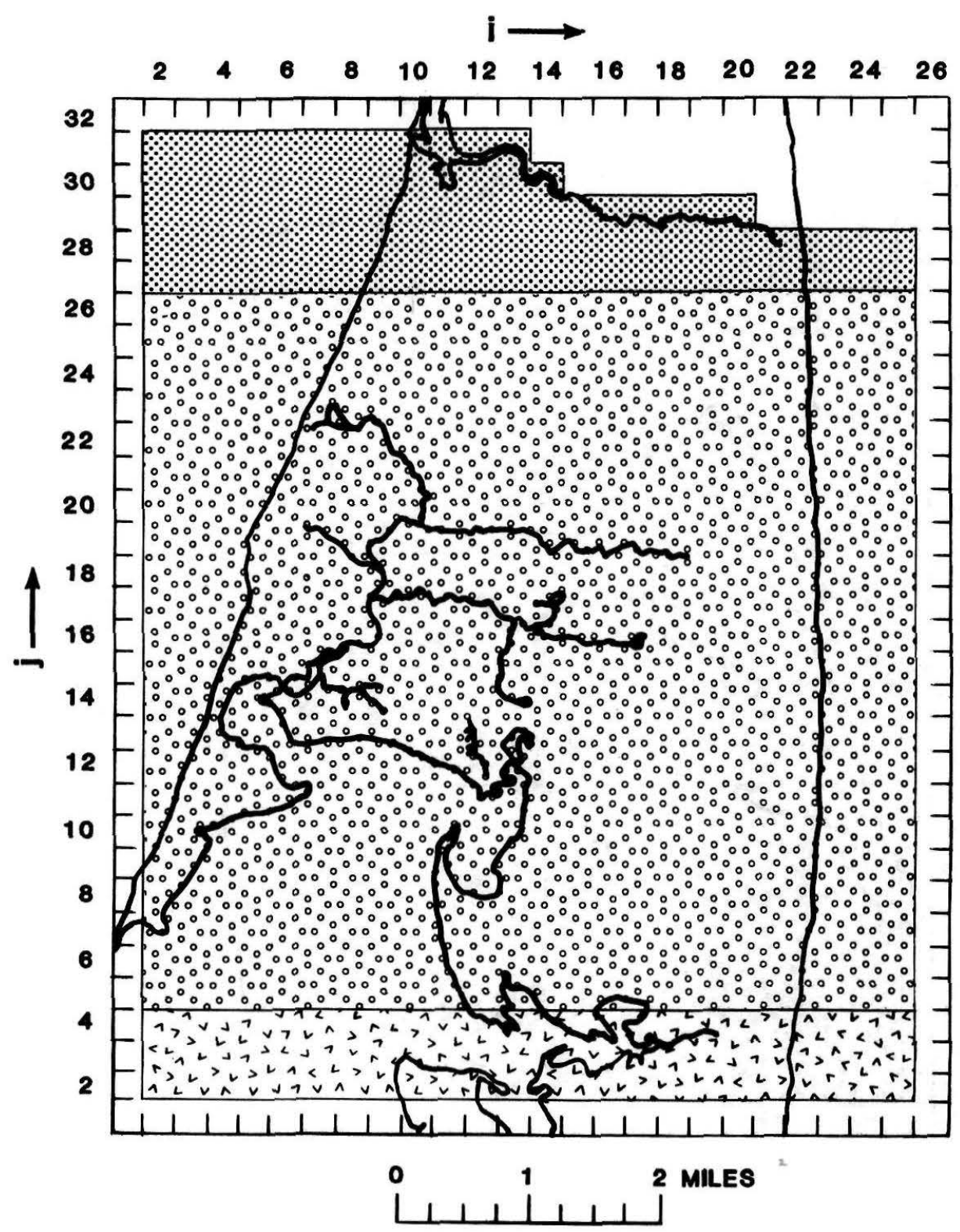

EXPLANATION

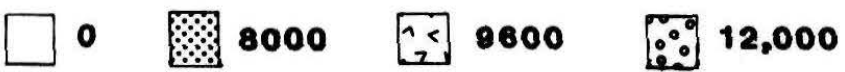

Figure 46.-- Transmissivity, in feet squared per day, WLFLT model, layer 6 

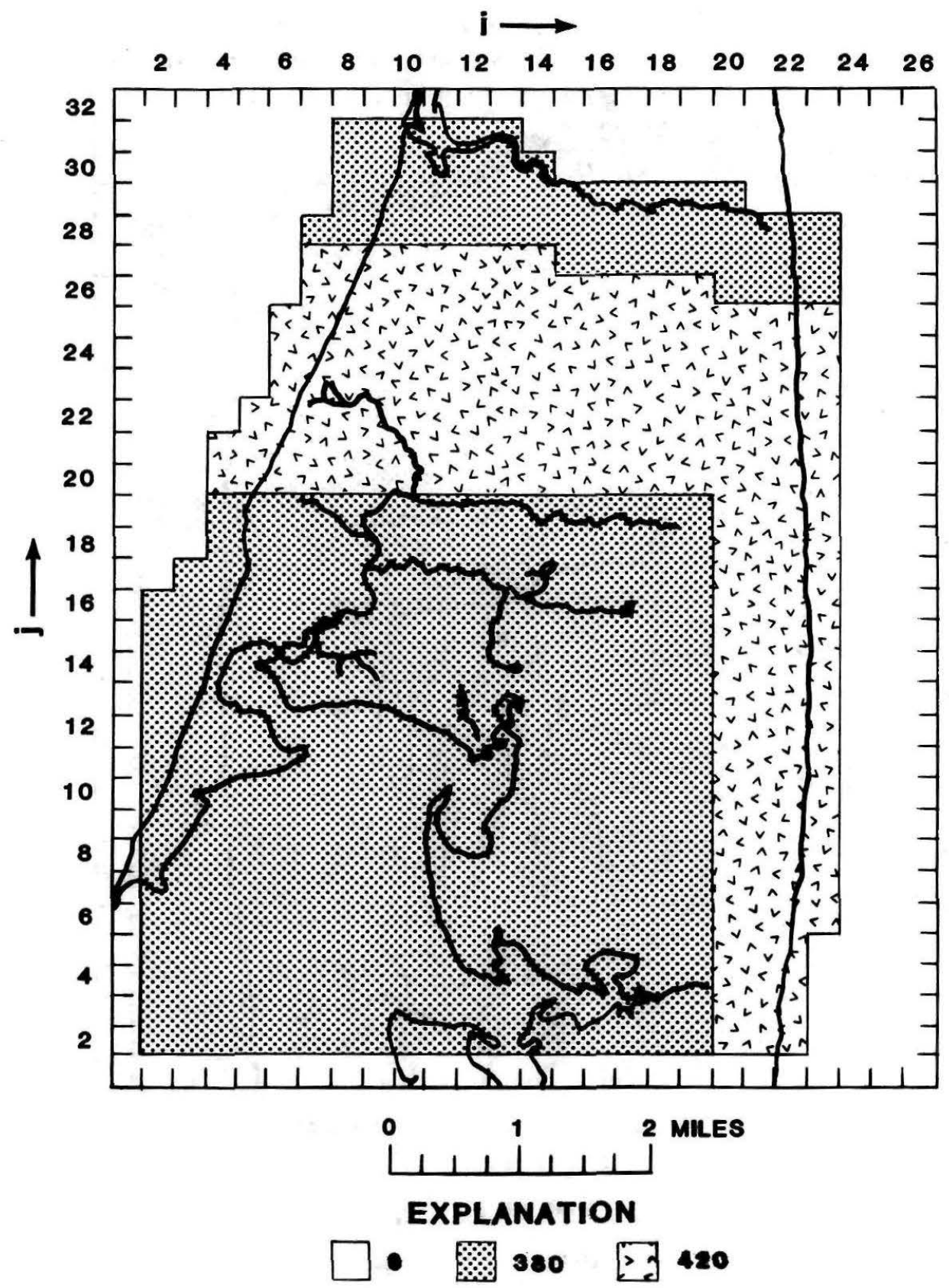

Figure 47.-- Hydraulic conductivity, in feet per day, WLFLT model, layer 7 


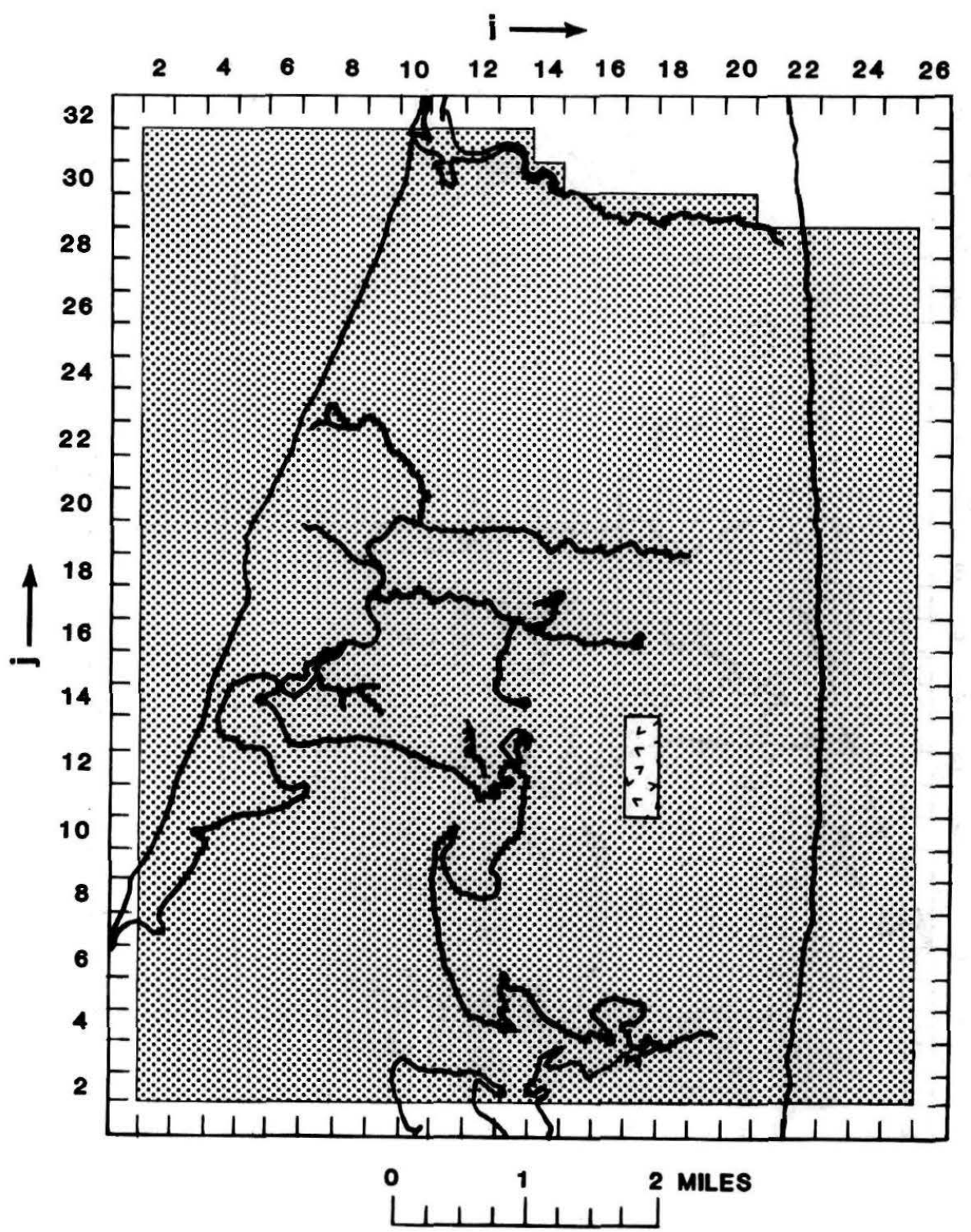

\section{EXPLANATION}

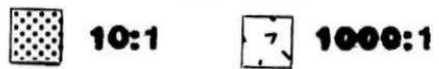

Figure 48.-- Ratio between lateral and vertical hydraulic conductivity, WLFLT model, layer 5 


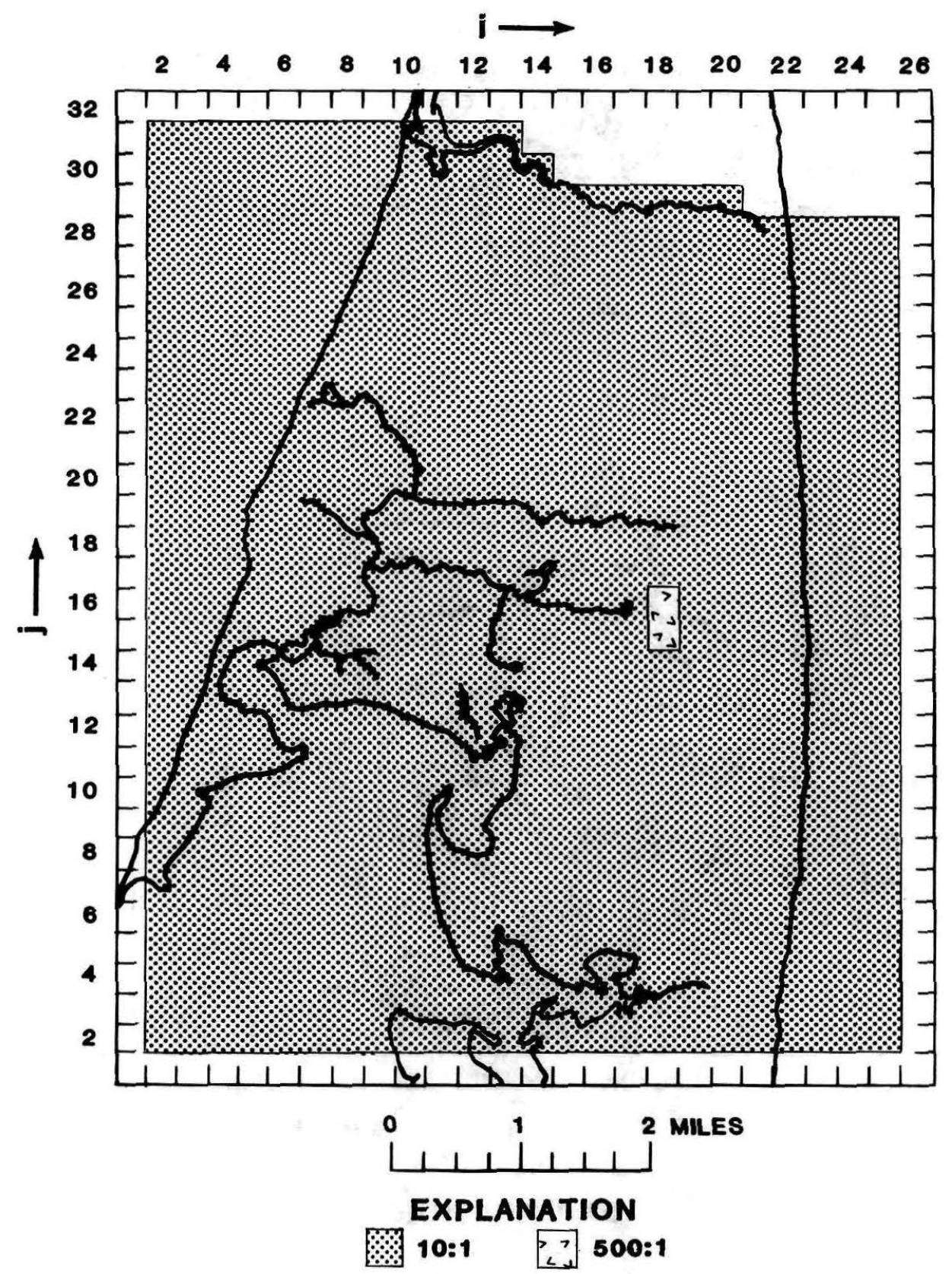

Figure 49.-- Ratio between lateral and vertical hydraulic conductivity, WLFLT model, layer 6 


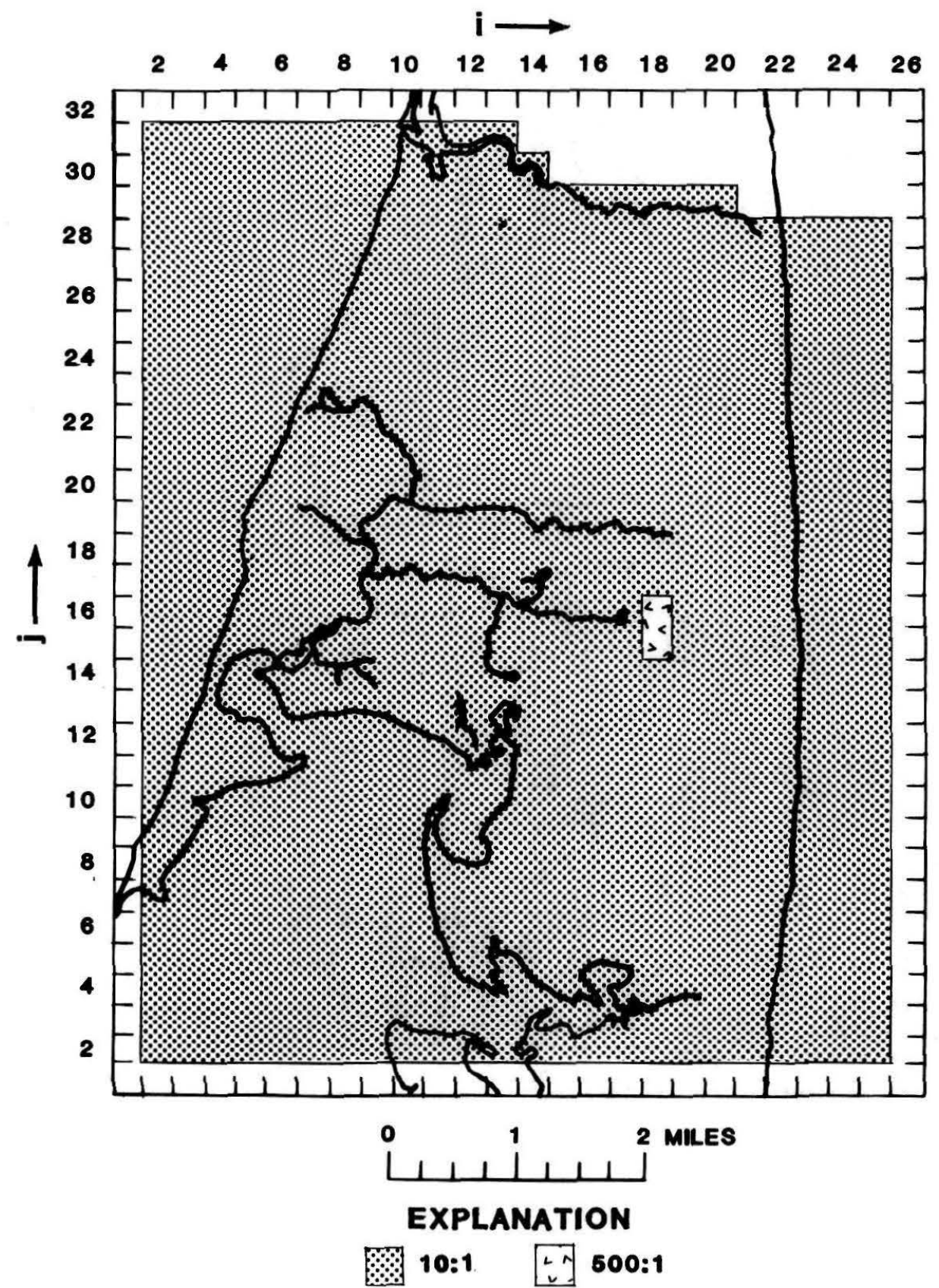

Figure 50.-- Ratio between lateral and vertical hydraulic conductivity, WLFLT model, layer 7 

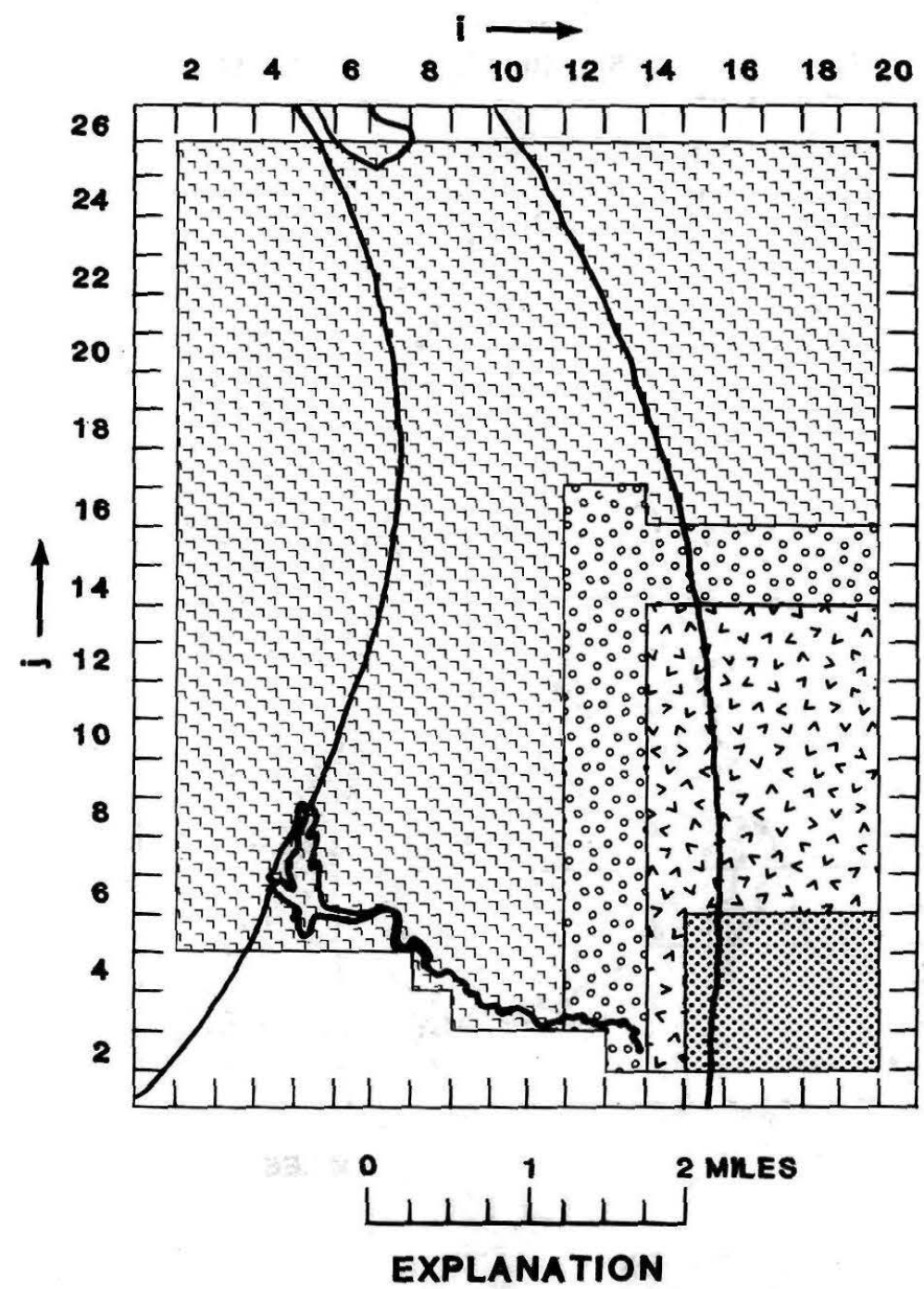

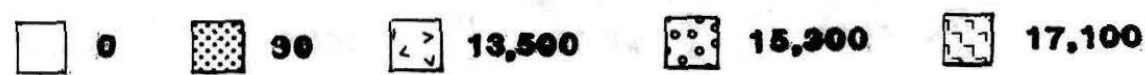

Figure 51.-- Transmissivity, in feet squared per day, TRURO model, layer 5 

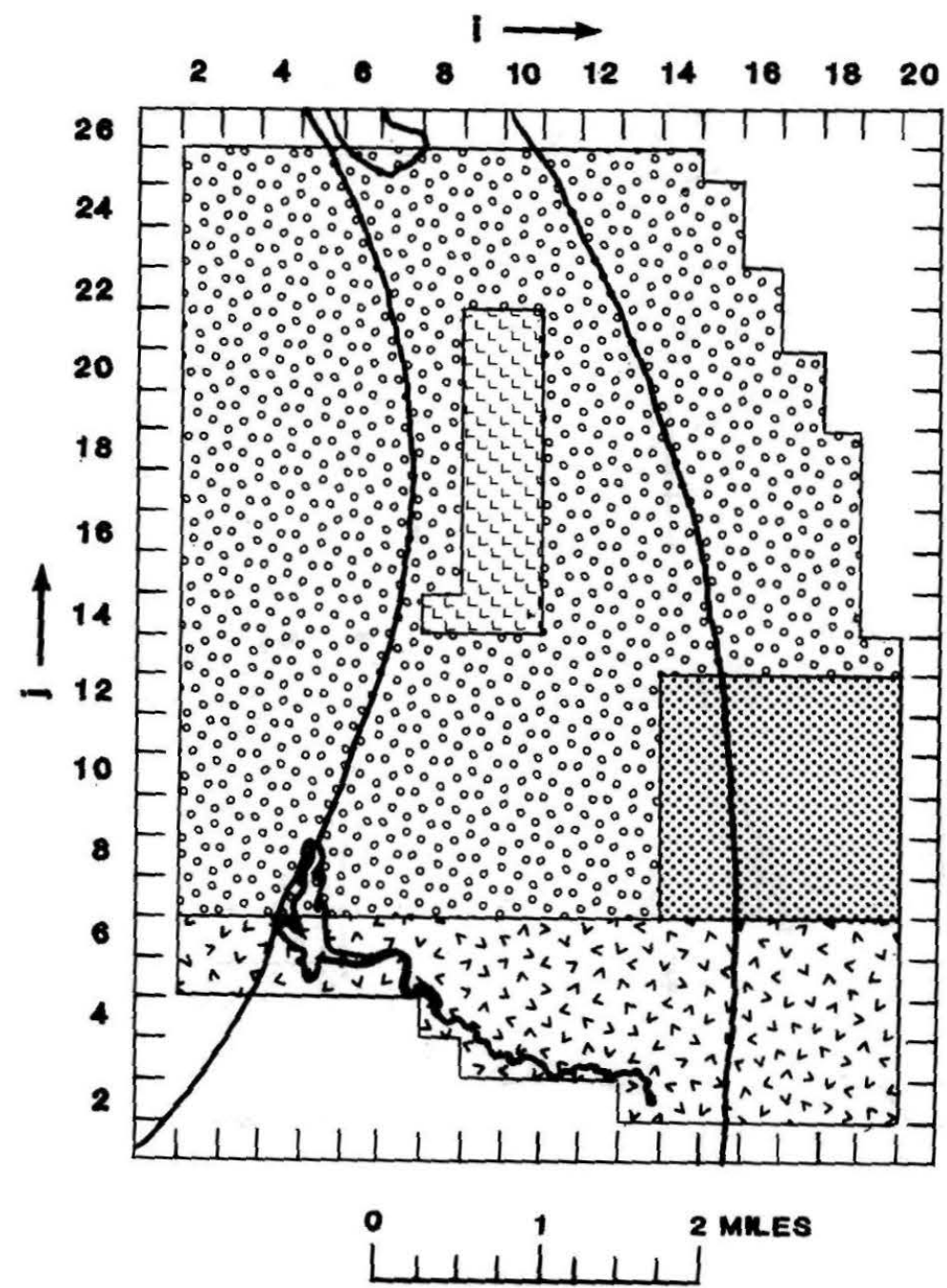

\section{EXPLANATION}

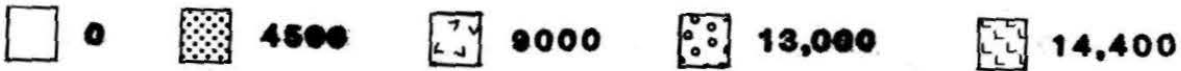

Figure 52.-- Transmissivity, in feet squared per day, TRURO model, layer 6 


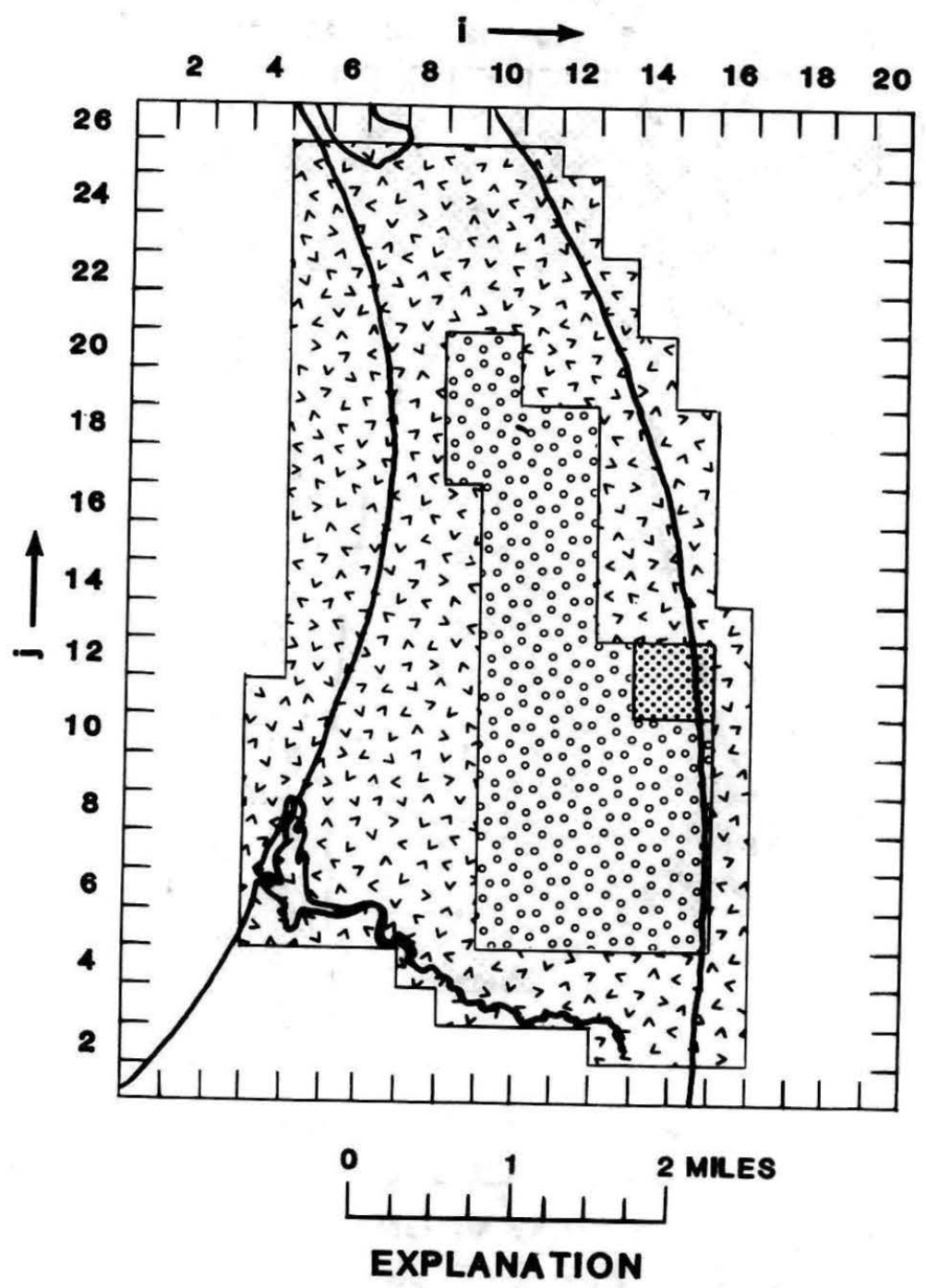

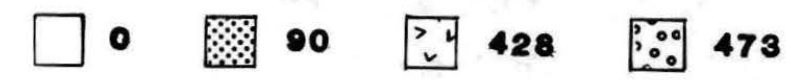

Figure 53.-- Hydraulic conductivity, in feet per day, TRURO model, layer 7 


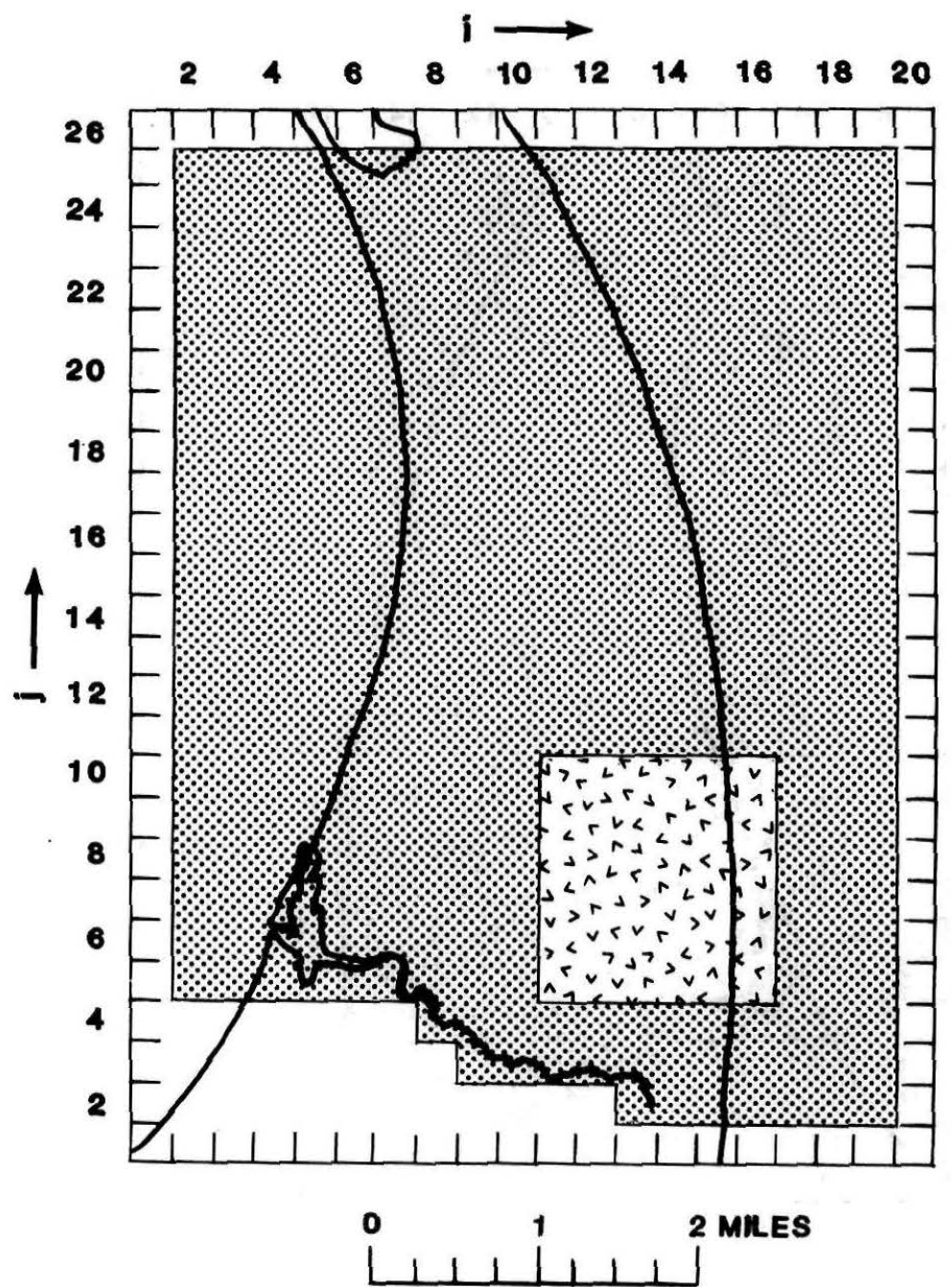

EXPLANATION

10:1 [i: 200:1

Figure 54.-- Ratio between lateral and vertical hydraulic conductivity, TRURO model, layer 5 

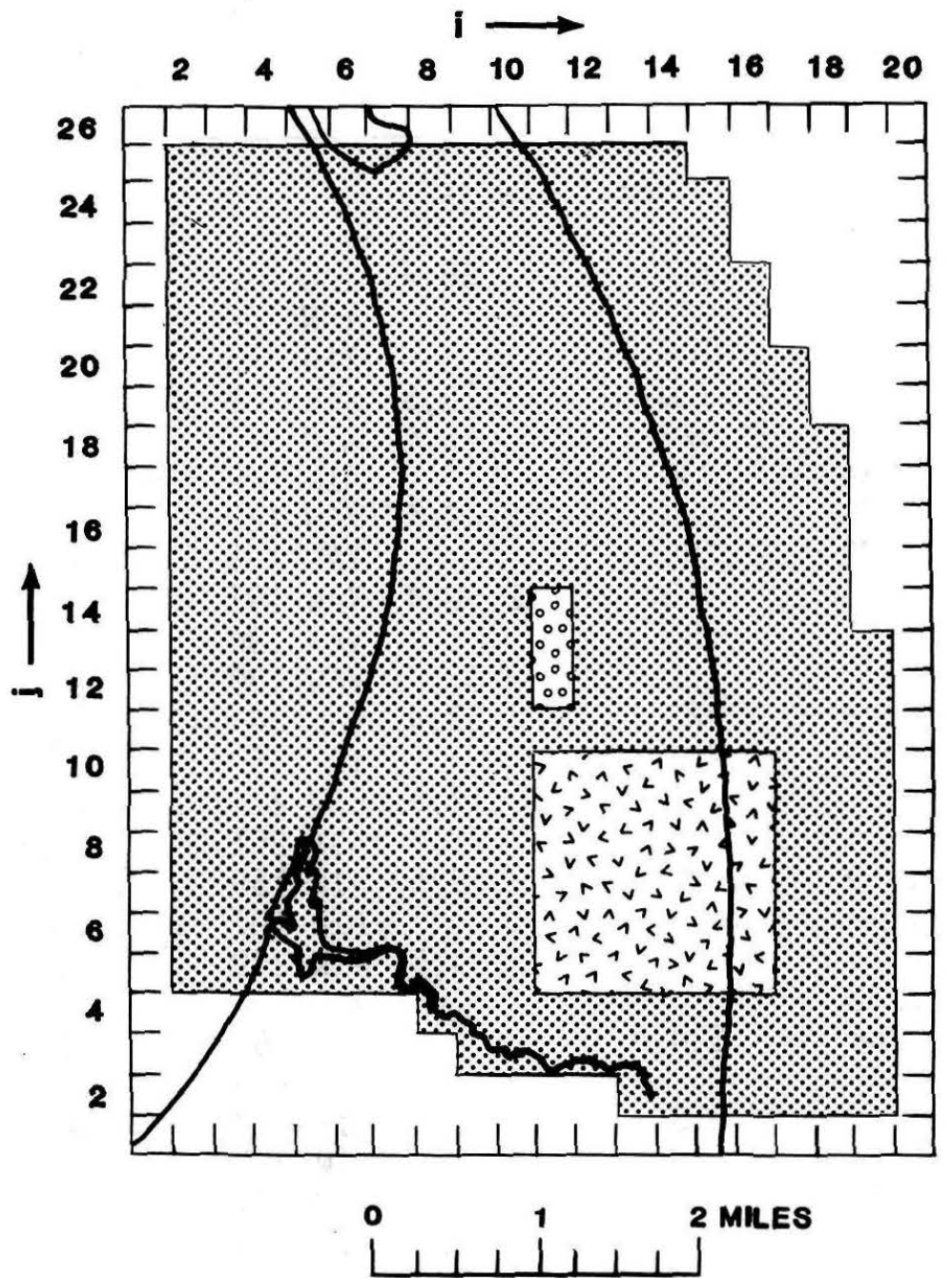

EXPLANATION

10:1 [ 200:1 $\because 30$ 1000:1

Figure 55.-- Ratio between lateral and vertical hydraulic conductivity, TRURO model, layer 6 
Table 10.--Sumary of well discharges represented in models

(*Indicates multiple well.)

\begin{tabular}{|c|c|c|c|c|c|c|c|}
\hline $\begin{array}{l}\text { Node } \\
(i, j, k)\end{array}$ & $\begin{array}{l}\text { U.S. } \\
\text { Geological } \\
\text { Survey } \\
\text { we } 11\end{array}$ & $\begin{array}{l}\text { Dis- } \\
\text { charge } \\
\left(\mathrm{ft}^{3} / \mathrm{s}\right)\end{array}$ & $\begin{array}{c}\text { Total } \\
\text { node } \\
\text { discharge } \\
\left(\mathrm{ft}^{3} / \mathrm{s}\right)\end{array}$ & $\begin{array}{l}\text { Node } \\
(i, j, k)\end{array}$ & $\begin{array}{l}\text { U.S. } \\
\text { Geological } \\
\text { Survey } \\
\text { well }\end{array}$ & $\begin{array}{l}\text { Dis- } \\
\text { charge } \\
\left(\mathrm{ft}^{3} / \mathrm{s}\right)\end{array}$ & $\begin{array}{c}\text { Total } \\
\text { node } \\
\text { discharge } \\
\left(\mathrm{ft}^{3} / \mathrm{s}\right)\end{array}$ \\
\hline
\end{tabular}

Mode 1: WCAPE

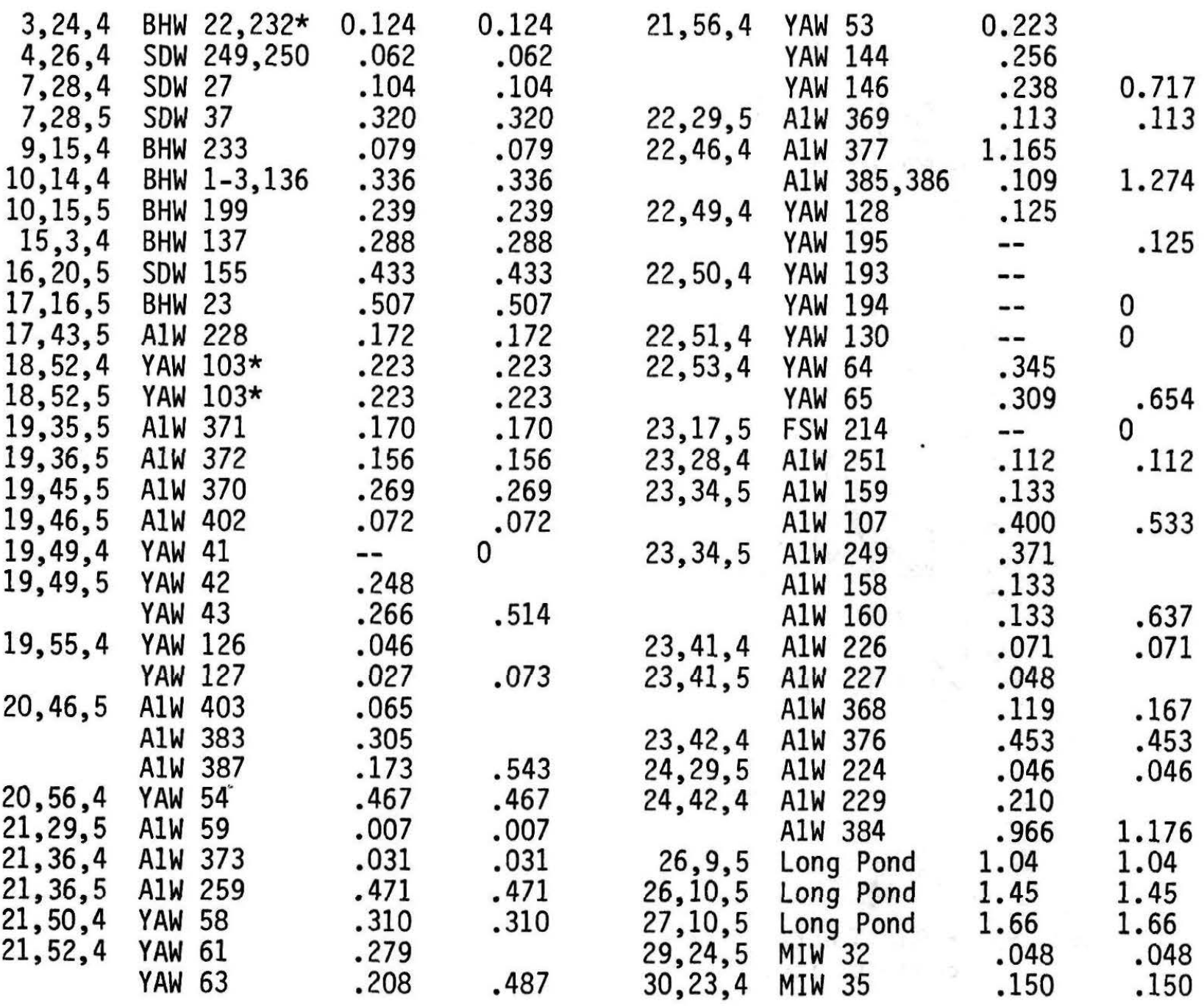

Model: ECAPE

$\begin{array}{llrlrlrl}8,28,4 & \text { OSW 11 } & 0.322 & & 11,11,5 & \text { DGW } 244 & -- & 0 \\ & \text { OSW 14 } & .206 & & 11,24,4 & \text { BMW } 37 & 0.287 & .287 \\ & \text { OSW 15 } & .277 & 0.805 & 12,9,5 & \text { DGW 112 } & .390 & .390 \\ 9,28,4 & \text { OSW 42 } & .041 & & 12,10,4 & \text { DGW 79 } & .527 & .527 \\ & \text { OSW 43 } & .088 & .129 & 12,11,5 & \text { DGW } 85 & .232 & .232 \\ 11,9,5 & \text { DGW 232 } & .015 & & 12,12,5 & \text { DGW 86 } & .139 & .139 \\ & \text { DGW 67 } & .059 & .074 & 12,24,4 & \text { BMW 41 } & .231 & .231\end{array}$


Table 10.--Summary of well discharges represented in models (Continued)

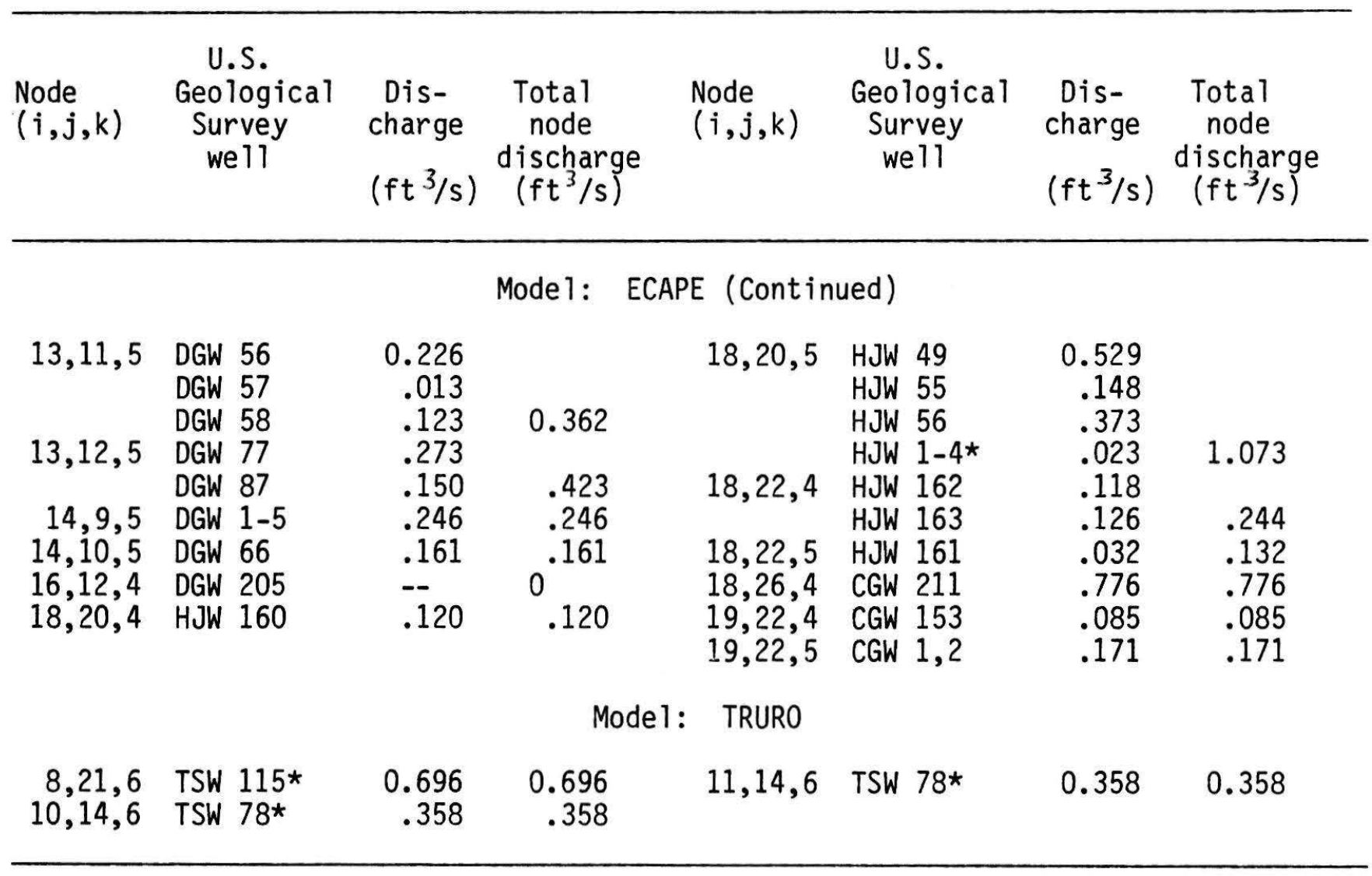



EXPLANATION

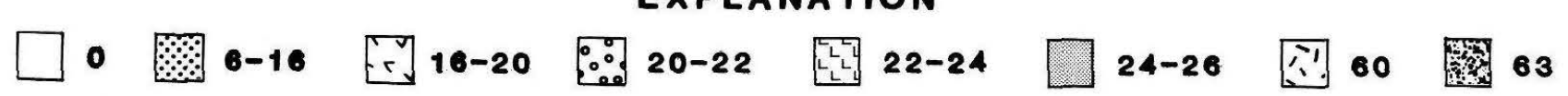

Figure 56.-- Steady-state recharge, in inches per year, WCAPE model 


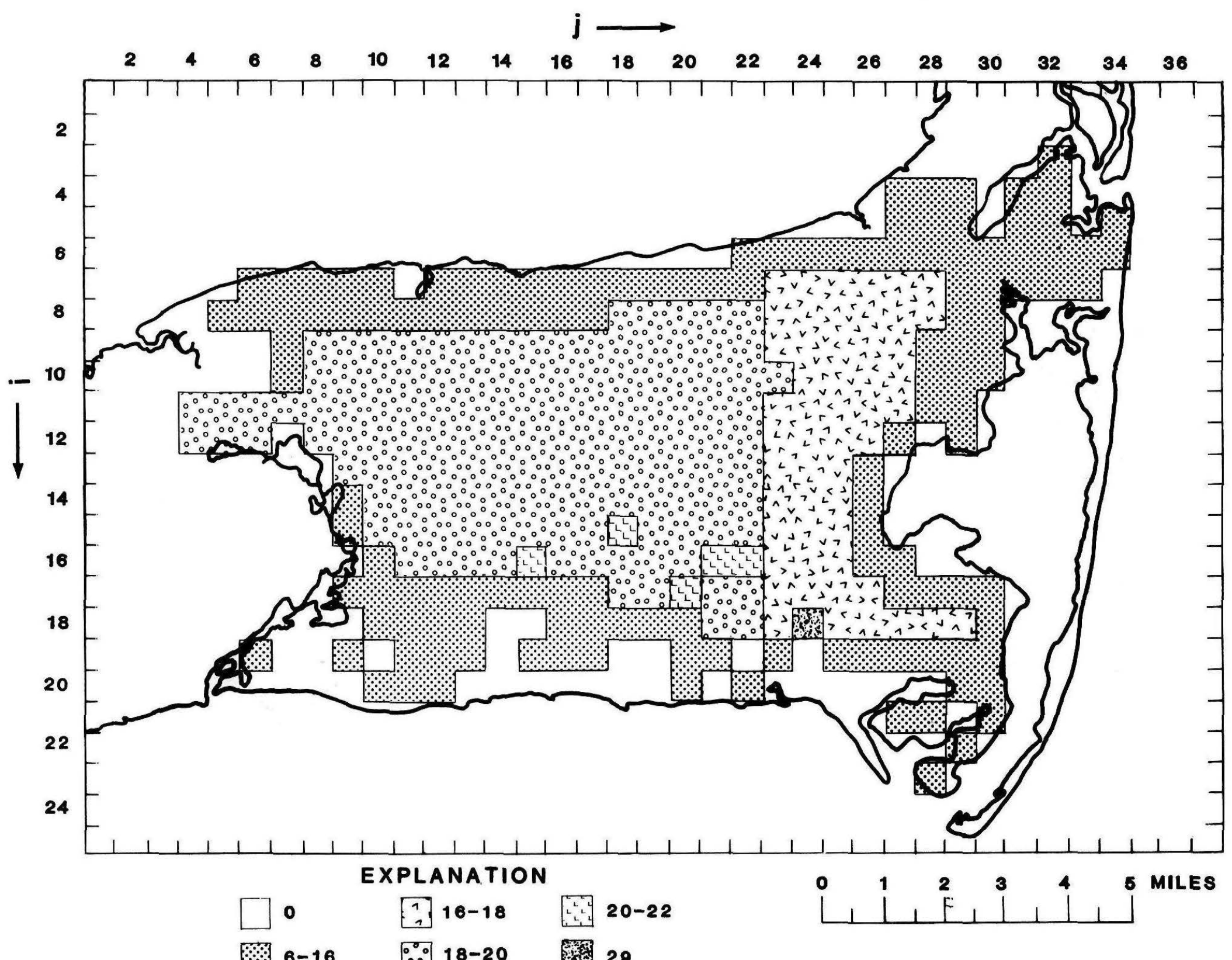

Figure 57.-- Steady-state recharge, in inches per year, ECAPE model 


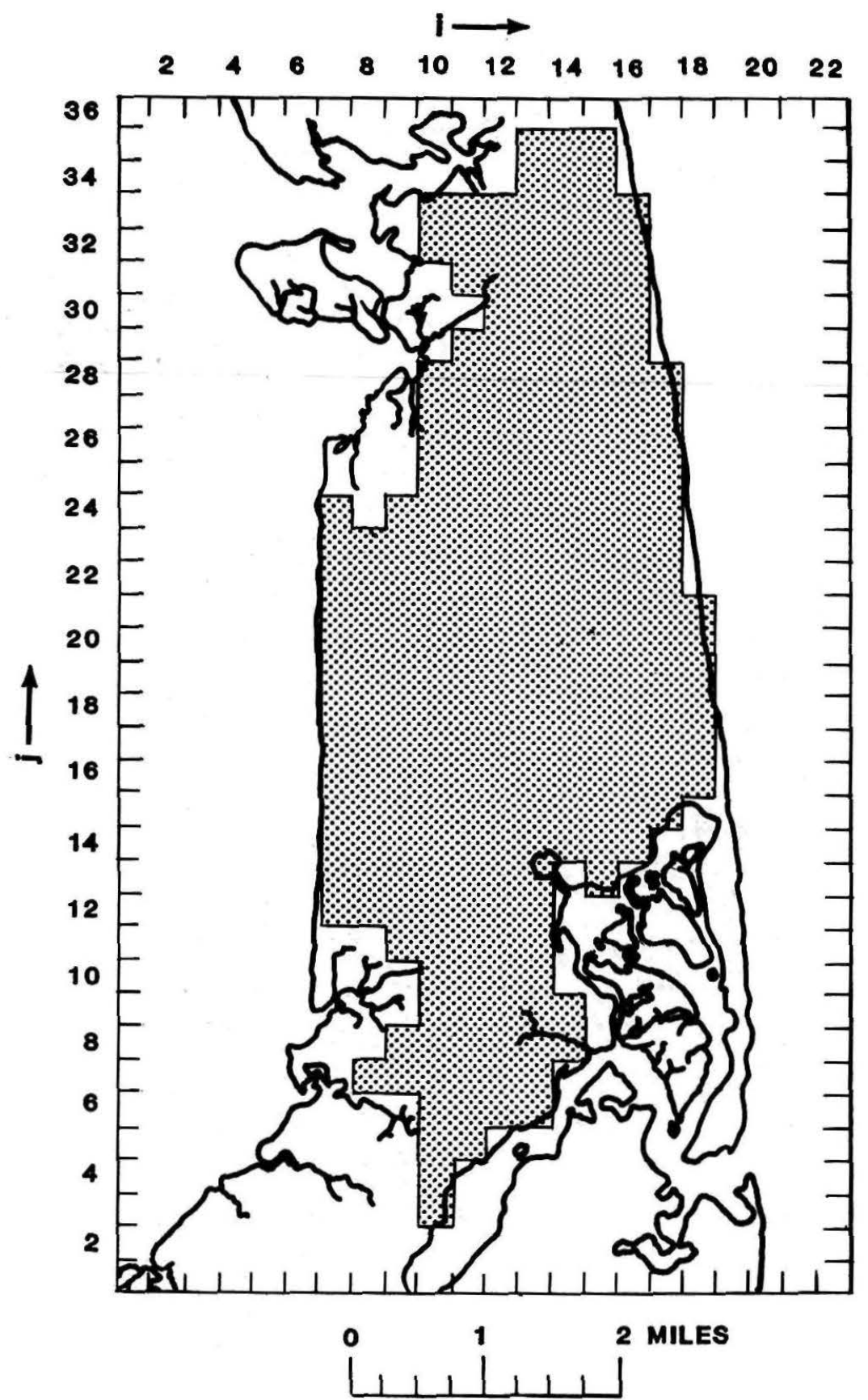

EXPLANATION

$\square 0 \quad 17$

Figure 58.-- Steady-state recharge, in inches per year, ESTHM model 


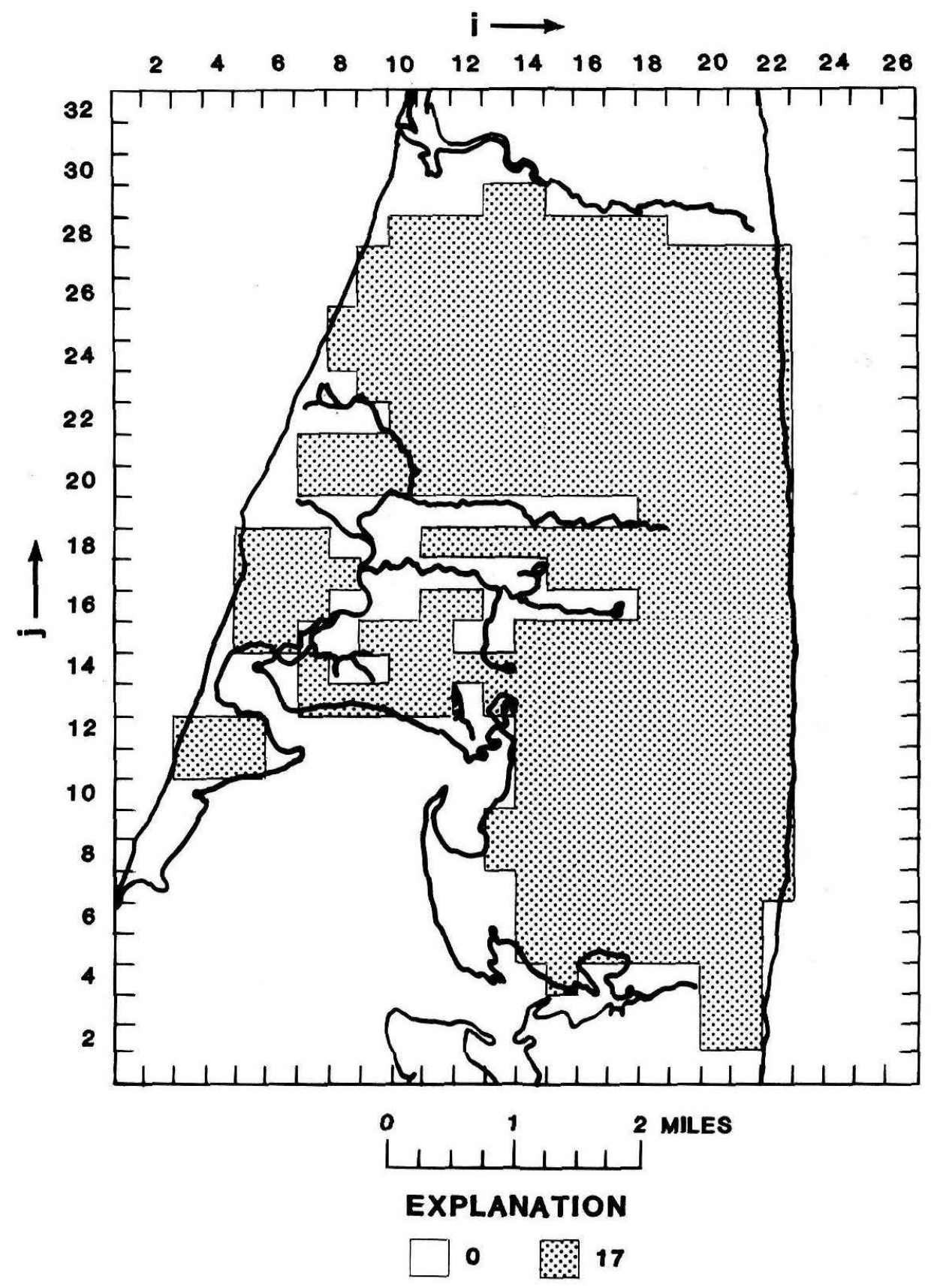

Figure 59.-- Steady-state recharge, in inches per year, WLFLT model 


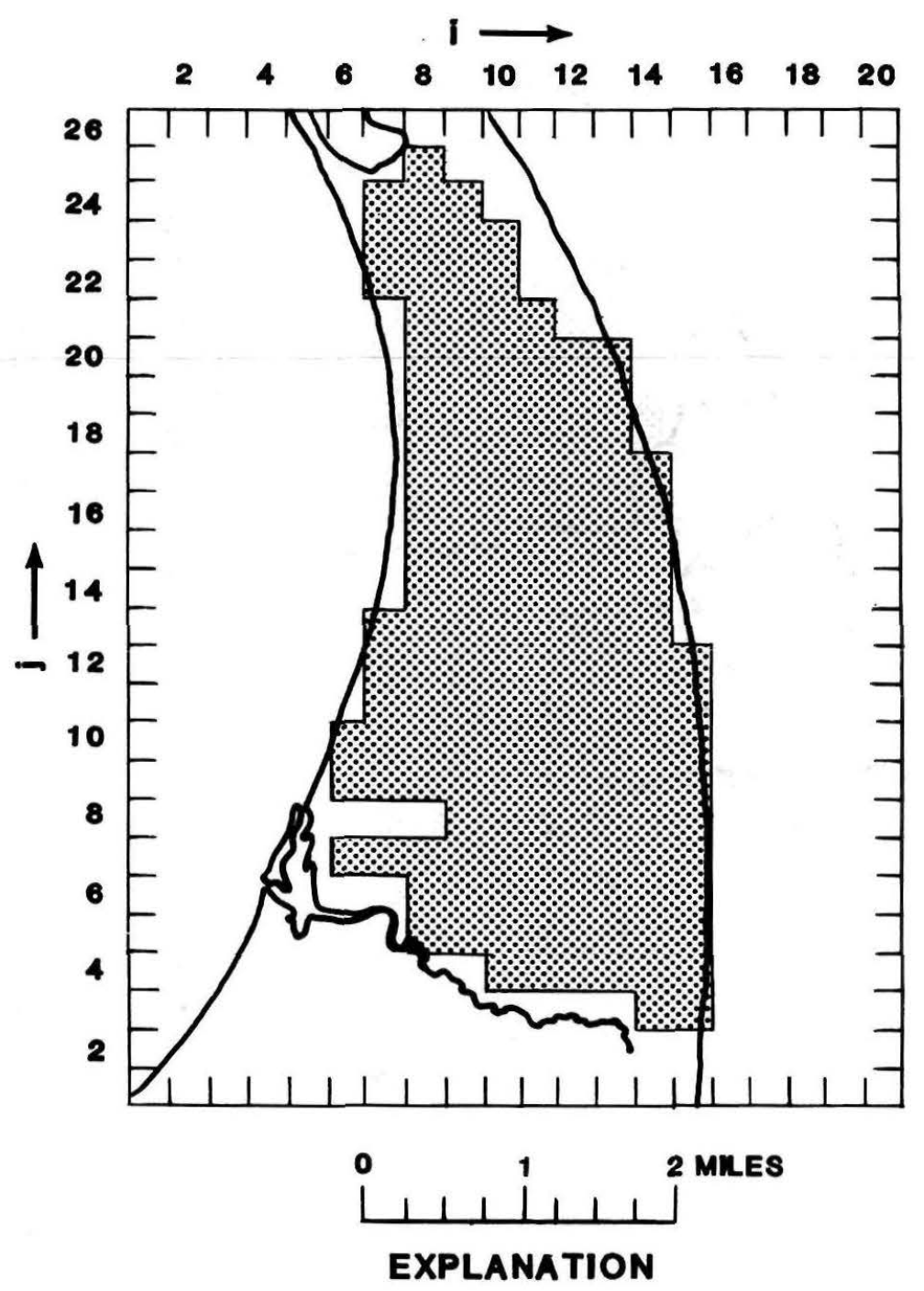

Figure 60.-- Steady-state recharge, In inches per year, TRURO model 
Table II.--Input documentation

Group l: Title, Simulation Options, and Problem Dimensions

This group of cards, which are read by the main program, contains data required to dimension the model. To specify an option on card 4 punch the characters underlined in the definition. For an option not used, that section of the card 4 can be left blank.

NOTE: 'Default typing of variables applies for all data input.

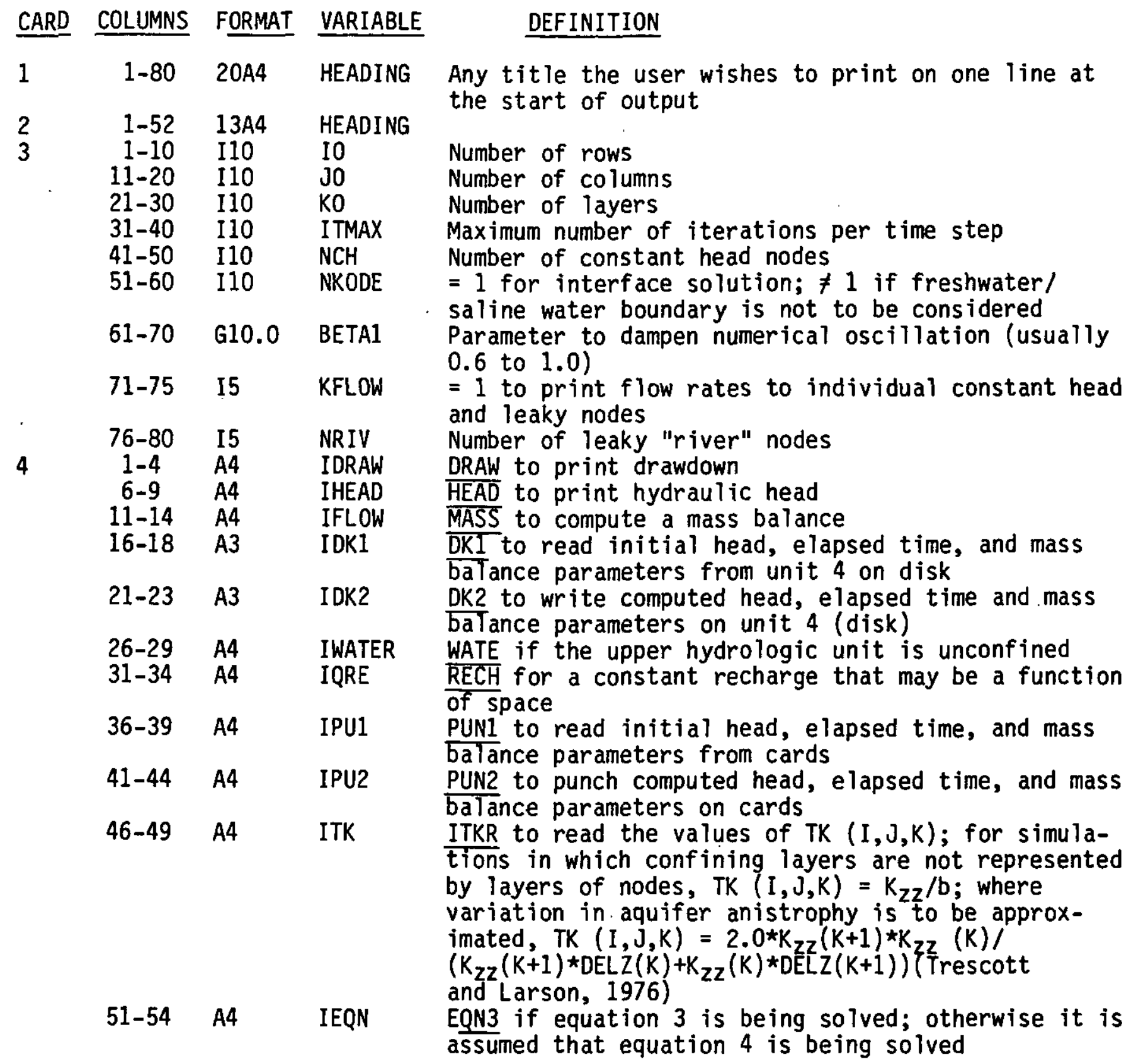




\section{Group 1I: Scalar Parameters}

The parameters required in every problem are underlined. The other parameters are required as noted; when not required, their location on the card can be left blank. The $G$ format is used to read $E, F$, and I format data. Minimize mistakes by always right-justifying data in the field. If $F$ format data do not contain significant figures to the right of the decimal point, the decimal point can be omitted.

CARD COLUMNS FORMAT VARIABLE DEFINITION

1 1-10 G10.0 NPER Number of pumping periods for the simulation

11-20 G10.0 KTH Number of times steps between printouts

NOTE: To print onTy the results for the final time step in a pumping period, make KTH greater than the expected number of time steps. The program always prints the results for the final time step.

21-30 G10.0 ERR Error criterion for closure (L)

NOTE: When the head change at all nodes on subsequent iterations is less than this value (for example, 0.01 foot), the program has converged to a solution for the time step.

$2 \quad$\begin{tabular}{rrr}
$31-40$ & G10.0 & LENGTH \\
\hline & $1-10$ & G10.0
\end{tabular}

Number of iteration parameters

Factor to convert model length unit to unit used in $x$ direction on maps (e.g. to convert from feet to mi les, XSCALE $=5280)$. For no maps, card 2 is blank)

11-20 G10.0 YSCALE Factor to convert model length unit used in $Y$

21-30 G10.0 DINCH $\quad \begin{aligned} & \text { direction on maps } \\ & \text { Number of map units per inch }\end{aligned}$

$31-40 \quad$ G10.0 FACT1

Factor to adjust value of drawdown printed*

41-49 911

LEVELI(I) Layers for which drawdown maps are to be printed. List layers starting in column 41; the first zero entry terminates the printing of drawdown maps

51-60 G10.0 FACT2 Factor to adjust value of head printed*

61-69 9I1 LEVEL2(I) Layers for which head maps are to be printed. List layers starting in column 61 ; the first zero entry terminates the printing of head maps.

$\left.\begin{array}{rrrl} & 71-78 & \text { A8 } & \text { MESUR } \\ 3 & 1-20 & \text { G20.10 } & \text { SUM } \\ & 21-40 & \text { G20.10 } & \text { SUMP } \\ & 41-60 & \text { G20.10 } & \text { PUMPT } \\ & 61-80 & \text { G20.10 } & \text { CFLUXT } \\ 4 & 1-20 & \text { G20.10 } & \text { QRET } \\ & 21-40 & \text { G20.10 } & \text { CHST } \\ & 41-60 & \text { G20.10 } & \text { CHDT } \\ & 61-80 & \text { G20.10 } & \text { FLUXT } \\ & 1-20 & \text { G20.10 } & \text { STORT } \\ & 21-40 & \text { G20.10 } & \text { ETFLXT } \\ & 41-60 & \text { G20.10 } & \text { FLXNT }\end{array}\right\}$
Name of map length unit

Parameters in which elapsed time and cumulative volumes for mass balance are stored. For the start of a simulation, insert three blank cards. For continuation of a previous run using cards as input, replace the three blank cards with the first three cards of punched output from the previous run. Using data from disk for input, leave the three blank cards in the data deck.

* Value of

\begin{tabular}{lrr}
$\begin{array}{l}\text { drawdown } \\
\text { or head }\end{array}$ & $\begin{array}{r}\text { FACT 1 } \\
\text { FACT 2 }\end{array}$ or $\begin{array}{r}\text { Printed } \\
\text { value }\end{array}$ \\
& 0.01 & 5 \\
52.57 & 0.1 & 53 \\
& 1.0 & 526 \\
& 10.0 & *** \\
\hline
\end{tabular}




\section{Group III: Array Dato}

Each of the following data sets (except data set 1) consists of a parameter card, and if the data set contains variable data, a set of data cards. If the data set requires data for each layer, a parameter card and data cards (for layers with variable data) are required for each layer. Each parameter card contains at least five variables.

$\frac{\text { CARD }}{\text { Every }} \frac{\text { COLUMNS }}{1-10} \frac{\text { FORMAT }}{\text { GIO.0 }}$ VARIABLE
FAC
Card

$\begin{array}{lll}11-20 & \text { G10.0 } & \text { IVAR } \\ 21-30 & \text { G10.0 } & \text { IPRN }\end{array}$

DEFINITION

If $\operatorname{IVAR}=0, \overline{F A C}$ is the value assigned to every element of the matrix for this layer If $I V A R=1, F A C$ is the multiplication factor for the following sets of data cards for this layer $=0$ if no data cards are to be read for this layer $=1$ if data cards for this layer follow $=0$ if input data for this layer are to be printed $=1$ if input data for the layer are not to be printed

Transmissivity Parameter Cards also have these Variables:

31-40 G10.0 $\mathrm{FACT}(\mathrm{K}, 1)$ Multiplication factor for transmissivity in $x$ direction

41-50 G10.0 $\operatorname{FACT}(K, 2)$ Multiplication factor for transmissivity in $y$ direction

51-60 G10.0 $\operatorname{FACT}(K, 3)$ Multiplication factor for hydraulic conductivity in the $z$ direction (Not used when confining bed nodes are eliminated and TK values are read)

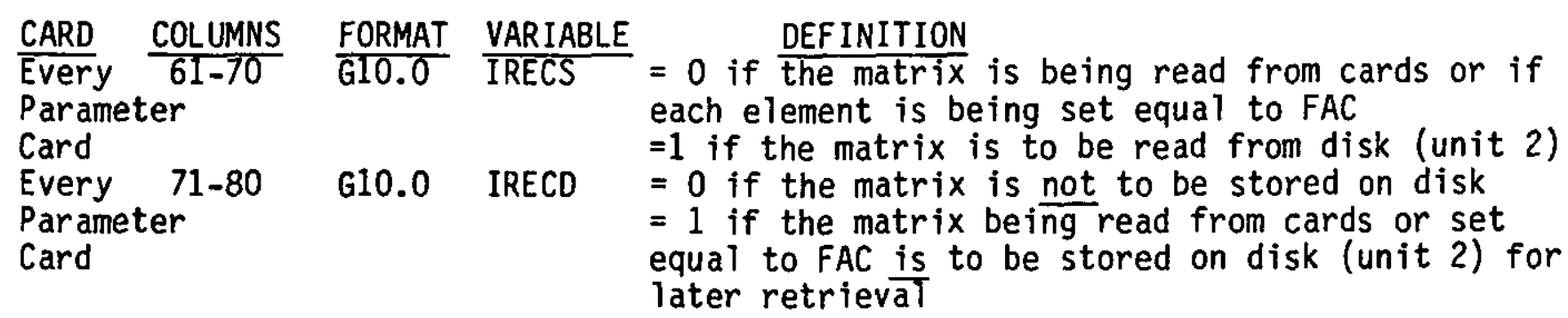

When data cards are included, start each row on a new card. To prepare a set of data cards for an array that is a function of space, the general procedure is to overlay the finite-difference grid on a contoured map of the parameter and record the average value of the parameter for each finite-difference block on coding forms according to the appropriate format. In general, record only significant digits and no decimal points (except for data set 2); use the multiplication factor to convert the data to their appropriate values. For example, if DELX ranges from 1000 to 15000 feet, coded values should range from I-15; the multiplication factor (FAC) would be 1000 .

DATA

SET COLUMNS FORMAT VARIABLE DEF INITION I $\frac{\text { I-80 }}{1-\mathrm{F} 10.4} \mathrm{P} \overline{\mathrm{HI}(\mathrm{I}, \mathrm{J}, \mathrm{K})}$ Head values for continuation of a previous run $(\mathrm{L})$ NOTE: For a new simulation this data set is omitted. Do not include a parameter card with this data set.
$2 \quad 1-80$ $8 F 10.4 \operatorname{STRT}(\mathrm{I}, \mathrm{J}, \mathrm{K})$
Starting head matrix (L)
$3 \quad 1-80 \quad 20 \mathrm{~F} 4.0 \mathrm{~S}(\mathrm{I}, \mathrm{J}, \mathrm{K})$
Storage coefficient (dimensionless). If equation
3 is to be solved, read $S_{S}$ instead of storage coefficient

NOTE: This matrix is also used to locate constant head boundaries by coding a negative number at constant head nodes. At these nodes, $T$ must be greater than zero. 
DATA

$\frac{\overline{S E T}}{4} \frac{\text { COLUMNS }}{1-80} \frac{\text { FORMAT }}{8 \mathrm{~F} 10.4} \frac{\text { VARIABLE }}{\text { T(I,J, } \mathrm{K})} \begin{aligned} & \text { Transmissivity } \\ & \text { solved, read hydraulic conductivity instead of } \\ & \text { transmissivity }\end{aligned}$

NOTE: 1) Zero values are required around the perimeter of the T matrix for each layer for reasons inherent in the computational scheme. This is done automatically by the program.

2) See the previous page for additional requirements on the parameter cards for this data set.

3) If the upper active layer is unconfined and PERM and BOTTOM are to be read for this layer, insert a parameter card for this layer with only the values for FACT on it.

$$
5 \quad 1-80 \quad 8 \mathrm{~F} \quad 10.4 \quad \mathrm{TK}(\mathrm{I}, \mathrm{J}, \mathrm{K}) \quad \mathrm{K}_{\mathrm{ZZ}} / \mathrm{b}
$$

NOTE: This data set is read only if specified in the options. The number of layers of TK values $=\mathrm{K} 0-\mathrm{I}$. See the discussion of the treatment of confining layers.

$\begin{array}{lllll}6 & 1-80 & 8 F \quad 10.4 & \operatorname{PERM}(I, J) & \begin{array}{l}\text { Hydraulic conductivity }(L / T) \text { (see note } 1 \text { for data } \\ \text { set } 4 \text { ) }\end{array} \\ 7 & 1-80 & 20 F \quad 4.0 & \operatorname{BOTTOM}(I, J) & \text { Elevation of bottom of water-table unit }(L)\end{array}$

NOTE: Data sets 6 and 7 are required only for simulating unconfined conditions in the upper hydrologic unit.

\section{$8 \quad 1-80 \quad 20 F \quad 4.0 \quad \operatorname{QRE}(I, J) \quad$ Recharge rate $(L / T)$}

NOTE: Omit if not used

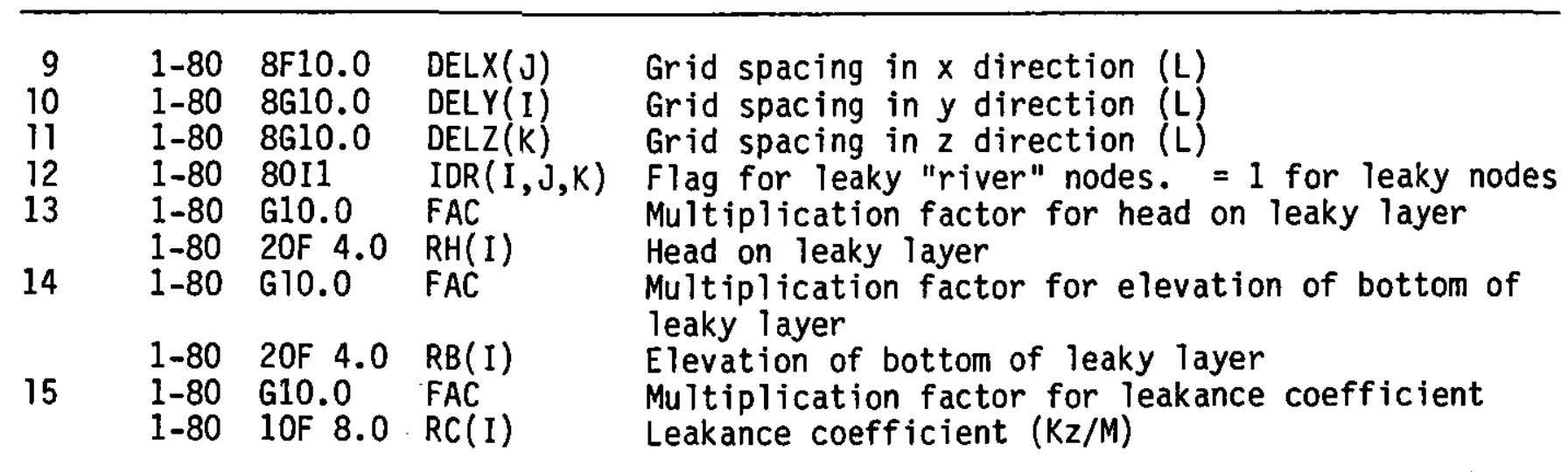


Group IV: Parameters that Change with the Pumping Period

The program has two options for the simulation period:

1. To simulate a given number of time steps, set TMAX to a value larger than the expected simulation period. The program will use NUMT, CDLT, and DELT as coded.

2. To simulate a given pumping period, set NUMT larger than the number required for the simulation period (for example, 50). The program will compute the exact DELT (which will be $\leq$ DELT coded) and NUMT to arrive exactly at TMAX on the last step.

$\frac{\text { CARD }}{1} \frac{\text { COLUMNS }}{1-10} \frac{\text { FORMAT }}{11-20} \frac{\text { VARIABLE }}{\text { G10.0 }}$

NOTE: KPM1 is currently not used

21-30 G10.0 NWEL Number of wells for this pumping period

31-40 G10.0 TMAX Number of days in this pumping period

41-50 G10.0 NUMT. Number of time steps

51-60 G10.0 CDLT Multiplying factor for DELT

NOTE: 1.5 is commonly used

$61-70$ G10.0 DELT. Initial time step in hours

If NWEL: 0 the following set of cards is omitted

DATA SET 1

$\begin{array}{ccc}\frac{\text { COL.UMNS }}{1-10} & \text { FORMAT } & \text { VARIABLE } \\ 11-20 & \text { G10.0 } & \text { K } \\ 21-30 & \text { G10.0 } & \mathrm{I} \\ 31-40 & \text { G10.0 } & \text { WELL }\end{array}$

(NWEL cards)

\section{DEFINITION}

Layer in which well is located

Row location of well

Column location of well

Pumping rate $\left(L^{3} / T\right)$, negative for a pumping well

For each additional pumping period, another set of group IV cards is required (that is, NPER sets of group IV cards are required).

Group V: Interface and Optional Print Parameters

(These data cards follow the first set of Group IV cards)

$\frac{\text { CARD }}{1} \frac{\text { COLUMNS }}{1-10} \frac{\text { FORMAT }}{110} \frac{\text { VARIABLE }}{\text { NTAD }}$

11-20 G10.0 RF

21-30 I10 KODCHP

$31-40 \quad I 10 \quad$ KPRNTT

DATA SET

\section{$1-80$}

$2 \quad 1-80 \quad 8011$

3

$16 \mathrm{~F} 5.0 \mathrm{DBO}$

$\operatorname{DBOT}(I, \mathrm{~J})$

$8011 \operatorname{ISEA}(\mathrm{I}, \mathrm{J})$

$1-80 \quad 8 G 10.0 \quad \operatorname{DTOP}(K)$

DEFINITION

Transmissivity adjustment code. Specifies frequency of transmissivity adjustment (e.g. = 1 every iteration; $=4$ every fourth iteration) Density factor = 1 Transmissivity adjustment proceeds across grid from north to south; otherwise adjustment proceeds from both north and south to mid-point of grid $=1$ write to file 9 final PHI, T, PERM and TK matrices

Elevation of bottom of aquifer (positive downward). Read similar to array data.

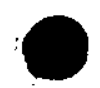
lag for "ocean" nodes. Assign value equal to node layer. Ocean nodes which "leak" into aquifer are treated as saline-water nodes Elevation of top of layers (positive downward) 
Group VI: Additional Print Parameters

CARD

1-10 I10 NODKOD $=1$ to print head values at each iteration for selected nodes

11-20 I10 NMBRND Number of nodes (-10 maximum) for which head values are to be printed

$2 \quad 1-80 \quad 10(13$,

I3, I2) $A A$ (I) I, J, K location of nodes for which hèad values are to

be printed. If NODKOD not equal to 1 omit this card
IHEDKD $=1$ write to file 8 final head values for selected

$3 \quad 1-10 \quad 110$ nodes

DATA

$\frac{\text { SET }}{1} \frac{\text { COLUMNS }}{1-80} \frac{\text { FORMAT }}{80 I 1} \frac{\text { VARIABLE }}{\text { IFNLHD }}$

DEFINITION

$(I, J, K)$ Index array to identify those nodes for which final head values are to be printed in table form. Two passes are made through the array. The first pass is made only on the top Tayer and prints head values for those nodes where IFNLHO $=1$. The second pass is made through the entire array and prints head values for those nodes where IFNLHD $=2$. If IHEDKD is not equal to 1 , omit this data set 
Table 12.--Computer source code

(*Indicates a change from Trescott, 1975, and Trescott and Larson, 1976.)

FINITE-DIFFERENCE MODEL FOR SIMULATION OF GROUND-WATER FLOW IN

MAN0010

THREE DIMENSIONS, SEPTEMBER 1975 BY P.C. TRESCOTT, U. S. G. S. MAN0020

WITH CONTRIBUTIONS TO MAIN, DATAI AND SOLVE BY S.P. LARSON

MAN0030

AND MODIFICATIONS NOTED BY ASTERISKS BY J.H.GUSWA AND D.R.LEBLANC MAN0045

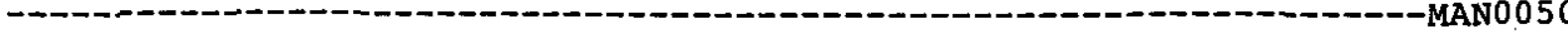

SPECIFICATIONS:

MANO060

REAL *8YSTR

MAN0070

MAN0080

MANOO9O

DIMENSION $Y(177500), I(29)$, HEADNG(33), NAME(42), INFT(2,2), IOFT(MAN0100* $19,4)$, DUM(3)

MANO110

EQUIVALENCE (YSTR,Y(1))

MANO 120

MANO 130

MANO 140

COMMON /INTEGR/ IO JO,KO,I $1, J 1, K 1, I, J, K, N P E R, K T H, I T M A X, I E N G T H, K P$, NMANO 150 १ WEL , NUMT, IFINAL, IT ,KT , IHEAD, IDRAW, IFLO, IERR, I2 , J2, K2, IMAX, ITMX1, NCMANO 160 $2 \mathrm{H}$, IDK 1, IDK 2 , IWATER, IRRE, IP, JP, IQ,JR, IK, JK, K5, IPU 1, IPU , ITK, IEQN MANO170 3 , NKODE, XFLOW

COMMON /SPARAM/ TMAX,CDLT,DELT,ERR,TEST,SUM, SUMP, RR,BETA ?

COMMON /SARRAY, ICHK(13), LEVEL1(9), LEVEL $2(9)$

MANO180*

MAN0190*

MANO200

c

DATA NAME/2*4H , 4H S, 4HTART, 4 HING, 4HHEAD, 4H, 4H STO, 4HRAGMANO220

$1 \mathrm{E}, 4 \mathrm{H}$ COE, $4 \mathrm{HFFIC,} 4 \mathrm{HIENT}, 2 * 4 \mathrm{H}$, $4 \mathrm{H}$ TR, 4 HANSM, 4 HISSI, 4HVITY, 5 H $4 \mathrm{H}$ MANO230

$2,4 \mathrm{H}$ TK, 4H HY, 4HDRAU, 4HLIC, 4HCOND, 4HUCTI, 4HVITY, 2*4H, 4HBOTMANO24O

3T, 4HOM E, 4HLEVA, 4HTION, $2 * 4 \mathrm{H}$, 4H R, 4HECHA, 4HRGE, 4HRATE/ MANO25O

D.TA INFT/4H(20F, 4H4.0), 4H(8F1,4H0.4)/ MANO26O

DATA IOFT: $4 \mathrm{H}(1 \mathrm{HO}, 4 \mathrm{H}, \mathrm{I2},, 4 \mathrm{H} 2 \mathrm{X}, 2,4 \mathrm{HOF} 6,4 \mathrm{H} /(5,4 \mathrm{HX}, 20,4 \mathrm{HF} 6.1,4 \mathrm{H}))$, MANO27O

$14 \mathrm{H}, 4 \mathrm{H}(1 \mathrm{HO}, 4 \mathrm{H}, \mathrm{I} 5,4 \mathrm{H} 14 \mathrm{~F} 9,4 \mathrm{H}, 5 /(, 4 \mathrm{H} 1 \mathrm{H},, 4 \mathrm{H} 5 \mathrm{X}, 1,4 \mathrm{H} 4 \mathrm{~F} 9,4 \mathrm{H} 5)), 4 \mathrm{H} \mathrm{MANO28O}$

$2,4 \mathrm{H}(1 \mathrm{HO}, 4 \mathrm{H}, \mathrm{I} 5,, 4 \mathrm{H} 10 \mathrm{E} 1,4 \mathrm{H} 2.5 /, 4 \mathrm{H}(1 \mathrm{H}, 4 \mathrm{H}, 5 \mathrm{X}, 4 \mathrm{H} 10 \mathrm{E} 1,4 \mathrm{H} 2.5), 4 \mathrm{H})$ MANO29O

C

$3,4 \mathrm{H}(1 \mathrm{HO}, 4 \mathrm{H}, \mathrm{I5}, 4 \mathrm{H} 10 \mathrm{E} 1,4 \mathrm{H} 1.3 /, 4 \mathrm{H}(1 \mathrm{H}, 4 \mathrm{H}, 5 \mathrm{X}, 4 \mathrm{H} 10 \mathrm{E} 1,4 \mathrm{H} 1.3), 4 \mathrm{H})$,

MAN0300

DEFINE FILE $2(8,1520, \mathrm{U}, \mathrm{KKK})$

$\operatorname{MANO} 310$

MANO320

C

DEFINE FILE $2(8,1520$, U, KkK)

MANO330

- -READ TITLE, PROGRAM SIZE AND OPTIONS---

MANO340

READ $(5,200)$ HEADNG

WRITE $(6,190)$ HEADNG

READ (5,160) IO, JO, KO, ITMAX, NCH, NKODE, BETA 1, KFIOW, NRIV

MANO350

MANO360

MANO370

WRITE $(6,180)$ IO,JO,KO,ITMAX, KCH, KKODE, BETA1, KFLOW, NRIV

MANO380*

$1, I E Q N$

WRITE $(6,220)$ IDRAW, IHEAD,IFLO,IDK1,IDK2, IWATER, IQRE, IPU1, IPU2, ITKM

MANO400

MANO410

$1, I E Q N$

IERR $=0$

MANO 440

C

IERR $=0$

MANO450

-- COMPUTE DIMENSIONS FOR ARRAYS---

$\mathrm{J} 1=\mathrm{J} 0-1$

$I 1=I 0-1$

$\mathrm{K} 1=\mathrm{K} O-1$

$I 2=I 0-2$

$\mathrm{J} 2=\mathrm{J} 0-2$

$\mathrm{K} Z=K O-2$

IMAX $=\operatorname{MAXO}(I 0, J 0)$

$N C D=M A X O(1, N C H)$

ITMX $1=I T M A X+1$

$I S I Z=I O * S O * K O$

$I K 1=I 0 * J 0$

MANO460

MANO 470

MANO 480

MANO49O

MANO500

MANO510

MANO520

MANO530

MANO540

MANO550

MAN0560

MANO570 
$\operatorname{IK} 2=\operatorname{MAXO}(\operatorname{IK} 1 * \mathrm{~K} 1,1)$

MAN0 580

ISUM $=2 *$ ISIZ +1

MANO590

$L(1)=1$

DO $30 \quad I=2,14$

IF (I.NE.8) GO TO 20

MANO600

$I(8)=I S U M$

MANO610

MANO620

$I S U M=I S U M+I K 2$

IF (IK2.EQ.1) GO TO 10

MANO 630

MANO640

$I K=I O$

$\mathrm{JK}=\mathrm{JO}$

$\mathrm{K} 5=\mathrm{K} 1$

GO TO 30

MAN0650

MANO660

MANO670

10

$I K=1$

$J K=1$

$K 5=1$

GO TO 30

MANO680

MANO690

MANO700

MANO710

MANO720

MANO730

MANO740

$20 \quad I(I)=I S U M$

MAN0750

ISUM = ISUM + ISIZ

30 CONTINUE

$I(15)=I S U M$

$I S U M=I S U M+J 0$

$L(16)=I S U M$

$I S U M=I S U M+I 0$

$I(17)=I S U M$

$I S U M=I S U M+K O$

$I(18)=I S U M$

ISUM = ISUM+ IMAX

$L(19)=I S U M$

I S UM $=$ I SUM $+K O * 3$

$I(20)=I S U M$

- $I S U M=I S U M+I T M X 1$

$L(21)=I S U M$

I SUM $=$ I SUM $+3 * N C D$

$I(22)=I S U M$

ISUM $=I S U M+N C D$

$I(23)=I S U M$

IF (IWATER.NE.ICHK(6)) GO TO 40

ISUM $=$ ISUM+IK 1

$L(24)=I S U M$

$I S U M=I S U M+I K 1$

$I P=I O$

$\mathrm{JP}=\mathrm{J} O$

GO TO 50

40 ISUM $=I S U M+1$

$I(24)=I S U M$

ISUM $=I S U M+1$

$I P=1$

$J P=1$

$50 I(25)=I S U M$

IF (IQRE.NE.ICHK(7)) GO TO 60

$I S U M=I S U M+I K 1$

$I R=I 0$

$\mathrm{J} Q=\mathrm{J} 0$

GO TO 70

60 ISUM $=I S U M+1$

$I Q=1$

$J \&=1$

MAN0760

MANO770

MANO 780

MANO790

MAN0800

MANO 810

MANO 820

MAN0830

MANO 840

MANO 850

MANO860

MANO870

MANO 880

MANO890

MANO9OO

MANO910

MANO920

MAN0930

MANO940

MANO950

MANO960

MANO970

MANO 980

MANO990

MAN 1000

MAN 1010

MAN 1020

MAN 1030

MAN 1040

MAN 1050

MAN 1060

MAN 1070

MAN 1080

MAN 1090

MAN 1100

MAN1110

MAN1120

MAN 1130

MAN 1140 
$c$

79 WRITE $(6,170)$ ISUM
70 IF(NRIV.EQ.0) GO TO 75

$I(26)=I S U M$

ISUM $=I S U M+I S I Z$

$I(27)=I S U M$

ISUM $=I S U M+N R I V$

$I(28)=I S U M$

ISUM $=I S U M+N R I V$

$I(29)=I S U M$

ISUM $=I S U M+N R I V$

GO TO 79

$75 I(26)=I S U M$

$L(27)=I S U M+1$

$L(28)=I S U M+2$

$L(29)=I S U M+3$

ISUM $=$ ISUM +4

MAN $1150 \%$

MAN $1160 \%$

MAN1170*

MAN1180*

MAN1190*

MAN $1200 *$

MAN $1210 *$

MAN $1220 *$

MAN $1230 \%$

MAN1240*

MAN 1250*

MAN $1260 \%$

MAN1270*

MAN 1280*

MAN $1290^{\circ}$

MAN1300*

MAN 1310

MAN 1320

CALI DATAI $(Y(I(1)), Y(L(2)), Y(L(3)), Y(I(4)), Y(L(5)), Y(I(6)), Y(I(7)) M A N 1330$ $1, Y(I(8)), Y(L(9)), Y(L(15)), Y(L(16)), Y(I(17)), Y(L(19)), Y(L(23)), Y(L(M A N 1340$ $224)), Y(L(25))$,

$3 Y(I(26)), Y(L(27)), Y(L(28)), Y(I(29)))$

MAN 1350

MAN 1360*

CALI STEP(Y(L(1)), Y(L(2)),Y(I(3)),Y(L(4)),Y(L(5)),Y(I(6)),Y(I(7)),MAN1370

$I Y(L(8)), Y(L(9)), Y(L(15)), Y(L(16)), Y(L(17)), Y(L(19)), Y(L(18)), Y(L(2 M A N 1380$

20) )

MAN 1390

CALL SOLVE $(Y(L(1)), Y(L(2)), Y(L(3)), Y(L(4)), Y(L(5)), Y(L(6)), Y(L(7)) M A N 1400$ $1, Y(L(8)), Y(L(9)), Y(I(15)), Y(I(16)), Y(I(17)), Y(L(19)), Y(L(10)), Y(I(M A N 1410$ $211)), Y(I(12)), Y(I(i 3)), Y(L(14)), Y(I(20)), Y(L(25)), Y(I(24))$, MAN 1420 $3 Y(I(23)), Y(L(26)), Y(I(27)), Y(L(28)), Y(L(29)), N R I V)$

$\operatorname{MAN} 1430 *$

CALL COEF(Y(L(1)),Y(L(2)),Y(L(3)),Y(I(4)),Y(L(5)),Y(L(6)), Y(I (7)), MAN1440 $1 Y(L(8)), Y(L(9)), Y(I(15)), Y(I(16)), Y(I(17)), Y(L(19)), Y(L(23)), Y(L(2 M A N 1450$ 24) ), Y(L(25)))

MAN 1460

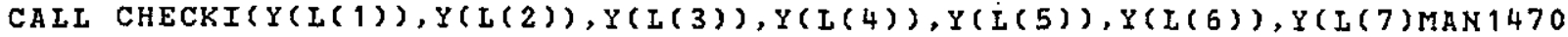

1), $Y(L(8)), Y(L(9)), Y(I(15)), Y(L(16)), Y(L(17)), Y(L(19)), Y(I(21)), Y(L M A N 1480$ $2(22)), Y(L(25))$,

MAN 1490

$3 Y(L(26)), Y(I(27)), Y(L(28)), Y(L(29)), N R I V)$

MAN $1500 *$

CALL PRNTAI $(Y(L(1)), Y(L(2)), Y(L(4)), Y(L(5)), Y(L(9)), Y(L(15)), Y(I(1 M A N 1510$ 16))

MAN 1520

MAN 1530

MAN 1540

MAN 1550

MAN 1560

MAN 1570

MAN 1580

MAN 1590

MAN 1600

MAN 1610

MAN 1620

MAN 1630

MAN 1640

MAN 1650

MAN 1660

MAN 1670

MAN 1680

MAN 1690

MAN 1700

MAN 1710 
$Y(I, 1)=\operatorname{DUM}(1)$

MAN 1720

$Y(L 2)=D U M(2)$

$\operatorname{MAN} 1730$

$Y(L 3)=\operatorname{DUM}(3)$

MAN 1740

MAN 1750

MAN 1760

IF (ITK.NE.ICHK (10)) GO TO 120

MAN 1770

DO $110 \mathrm{~K}=1, \mathrm{~K} 1$

$\mathrm{LOC}=\mathrm{I}(8)+(\mathrm{K}-1) * N I J$

110 CALI ARRAY (Y (LOC), INFT $(1,2), \operatorname{IOFT}(1,3), \operatorname{NAME}(19), \operatorname{IRN}, D U M)$

MAN 1780

MAN 1790

120 IF (IWATER.NE.ICHK $(6)$ ) GO TO 130

$\mathrm{K}=\mathrm{KO}$

CALL ARRAY (Y (L ( 23$)), \operatorname{INFT}(1,2), \operatorname{IOFT}(1,4), \operatorname{NAME}(25), \operatorname{IRN}, D U M)$

MAN 1800

MAN 1810

CALL ARRAY (Y (L (24)), INFT (1,1), IOFT(1,1), NAME(31), IRN, DUM)

MAK 1820

MAN 1830

130 IF (IQRE.ER.ICHK(7)) CAIL ARRAY(Y(L(25)), INFT(1,1), IOFT(1,4), NAME(MAN1840 137 ) , IRN, DUM)

CALI MDAT

IF(NRIV.NE.O) CALI DDATZ(NRIV)

C

C ---COMPUTE TRANSMISSIVITY FOR UNCONFINED LAYER---

IF (IWATER,EQ.ICHK(6)) CALL TRANS(1)

MAN 1850

MAN 1860

MAN $1870 *$

MAN 1880

MAN 1890

MAN 1900

C --DOMPUTE T COEFFICIENTS---

CALI TCOF

MAN 1910

MAN 1920

MAN 1930

C

C - COMPUTE ITERATION PARAMETERS- -

CALL ITER

MAN 1940

MAN 1950

MAN 1960

MAN 1970

C

C

140 CALI NEWPER

$K T=0$

IFINAL $=0$

C

c

150 CALL NEWSTP

C - -START MEW ITERATION IF MAXIMUM NO. ITERATIONS NOT EXCEEDED--CALI NEWITA

C - - PRINT OUTPUT AT DESIGNATED TIME STEPS---

CALL OUTPUT

C

C

C

$\mathrm{C}$
$\mathrm{C}$
$\mathrm{C}$
$\mathrm{C}$

160 FORMAT (6I10,G10.0,2I5)

170 FORMAT ('O',54X, 'WORDS OF VECTOR Y USED $=\cdot, I 7)$

180 FORMAT ('O',62X,' NUMBER OF ROWS $=', I 5 / 60 \mathrm{X}$, 'NUMBER OF COLUMNS =', I5MAK2270

$1 / 61 \mathrm{X}$, 'NUMBER OF LAYERS $=$ ', I5/39X,'MAXIMUM PERMITTED NUMBER OF ITEMAN2280
MAN 1990

MAN 2000

MAN2010

MAN2020

MAN2030

MAN2040

MAN2050

MAN2060

MAN2070

MAN2080

MAN 2090

MAN2 100

MAN2 110

MAN2 120

MAN2 130

MAN2 140

MAN2 150

MAN2 160

MAN2 170

MAK2 180

MAN2 190

MAN2 200

MAN2 210

MAN2220

$\operatorname{MAN} 2230$

MAN2 240

MAN2 250*

MAN2 260 


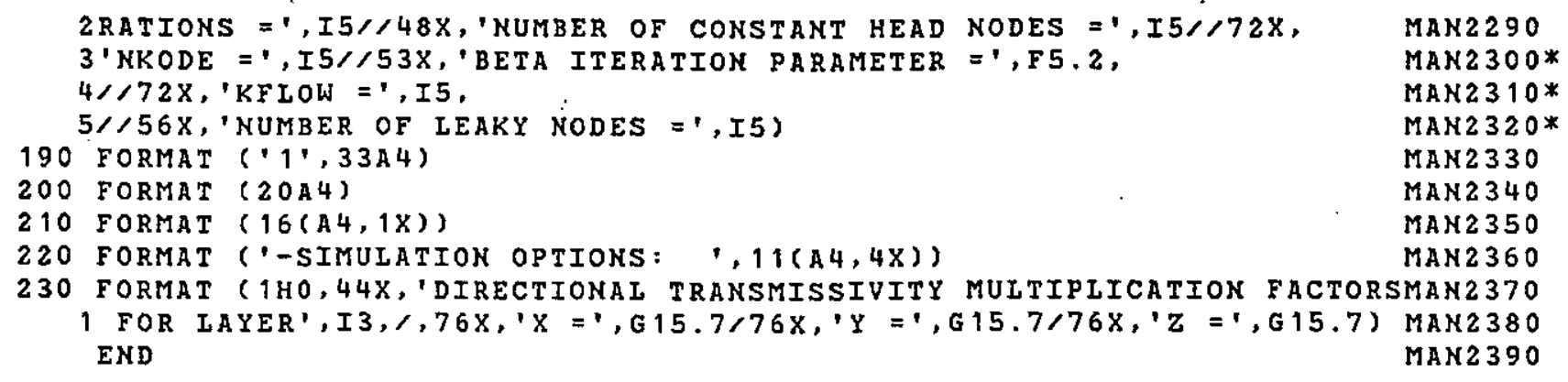


SUBROUTINE STEP(PHI, STRT, OLD,T,S,TR, TC,TK, WELL, DELX, DELY, DELZ, FACTSTPOO10 1, DDN, TEST 3 ) STP0O20

c

C

C

SPECIFICATIONS :

REAL * 8 PHI

REAL *8XLABEL, YLABEL, TITLE, XN 1 , MESUR

STP0030

INITIAIIZE DATA FOR A NEW TIME STEP AND _PRINT RESUITS ... STPOO4O

(1)

STP 0060

$S T P 0070$

STP 0080

STP0090

$\operatorname{STP} 0100$

DIMENSION PHI(IO,JO,KO), STRT(IO,JO,KO), OLD(IO,JO,KO), T(IO,JO,KOSTPO110

1), $\mathrm{S}(I 0, \mathrm{JO}, \mathrm{KO}), \mathrm{TR}(I 0, J 0, K O), \mathrm{TC}(I 0, \mathrm{JO}, K 0), \mathrm{TK}(I K, J K, K 5)$, WELI(IO,STPO120

$2 J 0, k 0)$, DELX(JO), DELY(IO), DEIZ(KO), FACT(KO,3), DDN(IMAX), TEST3STPO130

$3(\operatorname{TMX} 1), \operatorname{ITTO}(50)$

STP 0140

C

$1 W E I$, NUMT, IF INA I , IT , KT, IHEAD, IDRAW, IFLO, IERR, I2, J2, K2, IMAX, ITMX 1, NCSTPO 170

$2 \mathrm{H}, I D K 1, I D K 2, I W A T E R, I Q R E, I P, J P, I Q, J Q, I K, J K, K 5, I P U 1, I P U 2, I T K, I E Q N$

3, NKODE, KFLOW

COMMON /SPARAM/ TMAX, CDLT,DELT,ERR,TEST,SUM, SUMP, QR, BETA 1

COMMON /SARRAY/ ICHK( 13 ), LEVELI( 9 ), LEVEL $2(9)$

STP 0180

STP0190*

STP0200*

COMMON /PR/ XLABEL(3), YLABEL (6), TITLE (6), XN1, MESUR, PRNT(122), BLANKSTPO230

$1(60), \operatorname{DIGIT}(122), \operatorname{VF} 1(6), \operatorname{VF} 2(6), \operatorname{VF} 3(7), X S C A L E, D I N C H, S Y M(17), X N(100), S T P O 240$

$2 Y N(13), N A(4), N 1, N 2, N 3, Y S C A L E, F A C T 1, F A C T 2$

STP 0250

RETURN

STP0260

C

C

$* * * * * * * * * * * * * * * * * * * *$

STP0270

ENTRY NEWSTP

STPO 280

STPO 290

STP0300

$\mathrm{KT}=\mathrm{KT}+\mathrm{I}$

$I T=0$

DO $10 \quad K=1, K O$

DO $10 \quad I=1, I 0$

DO $10 \mathrm{~J}=1, \mathrm{~J} 0$

$10 \operatorname{OLD}(I, J, K)=\operatorname{PHI}(I, J, K)$

DELT $=$ CDLT *DELT

$S U M=S U M+D E L T$

SUMP $=S U M P+D E L T$

DAYSP $=S U M P / 86400$.

$Y R S P=D A Y S P / 365$.

HRS $=S U M / 3600$

SMIN $=$ HRS $* 60$.

$D A Y S=H R S / 24$.

$Y R S=D A Y S / 365$.

RETURN

C

C

c

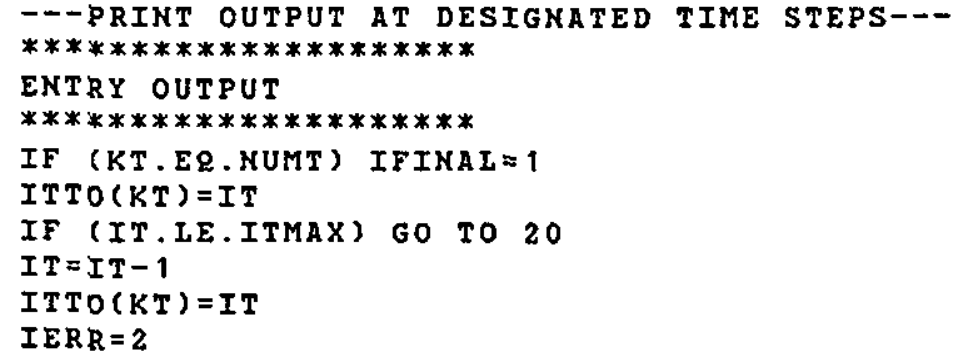

STP0320

STP 0330

$S T P O 340$

STP0350

STP0360

STP0370

STPO380

STPO390

STP0 400

STPO 410

STPO 420

STP0 430

STP 0440

STP 0450

STP0 460

STP0470

STP0 480

STPO 490

STP0500

STP0 510

STP0 520

STP0 530

STP0 540

STP0 550

STP0560

STP0570 
C

20 IF (IFLO.EQ.ICHK(3)) CALI CHECK

IF (IERR.EQ.2) GO TO 30

IF (MOD (KT,KTH).NE.O.AND. IFINAL.NE.1) RETURN

30 WRITE $(6,210) \mathrm{KT}$, DELT, SUM, SMIN, HRS, DAYS, YRS, DAYSP, YRSP

IF (IFLO.EQ.ICHK( 3 ) ) CALI CWRITE

$I T=I T+1$

WRITE $(6,180)(\operatorname{TEST} 3(J), J=1, I T)$

$I 3=1$

$I 5=0$

$352 I 5=I 5+40$

$I 4=M I N O(K T, I 5)$

WRITE $(6,240) \quad(I, I=I 3, I 4)$

WRITE $(6,260)$

WRITE $(6,250)$ (ITTO(I), I $=I 3, I 4)$

WRITE $(6,260)$

IF (KT.LE.I5) GO TO 353

$I 3=I 3+40$

GO TO 352

c

C

353 IF (XSCALE.EQ.O.) GO TO 70

IF (FACT1.EQ.0.) GO TO 50

DO $40 \quad I A=1,9$

$I I=I E V E L 1$ (IA)

IF (II.EQ.O) GO TO 50

40 CALL PRNTA $(1$, II)

50 IF (FACT2.EQ.0.) GO TO 70

DO $60 \quad I A=1,9$

$I I=I E V E L 2(I A)$

IF (II.EQ.0) GO TO 70

60 CALL PRNTA (2, II)

$\mathrm{C}$

70 IF (IDRAW.NE.ICHK(1)) GO TO 100

C -DPRINT DRAWDOWN---

DO $90 K=1, K 0$

WRITE $(6,200) \mathrm{K}$

DO $90 I=1, I 0$

DO $80 \mathrm{~J}=1, \mathrm{~J} 0$

$80 \operatorname{DDN}(J)=\operatorname{STRT}(I, J, K)-\operatorname{PHI}(I, J, K)$

90 WRITE $(6,170) I,(D D N(J), J=1, J 0)$

c

100 IF (IHEAD.NE.ICHK(2)) GO TO 120

C ---PRINT HEAD MATRIX---

DO $110 \mathrm{~K}=1, \mathrm{KO}$

WRITE $(6,190) \mathrm{K}$

Do $110 \quad I=1$, I0

c

110 WRITE $(6,170) \quad I,(P H I(I, J, K), J=1, J 0)$

C ---WRITE ON DISK---

120 IF (IERR.EQ.2) GO TO 130
STP0 580

STP 0590

TSTP0600

STP0610

TS TP 0620

STP0630

STP0640

STP0650

STP0660

STP0 670

STP0 680

STP0690

STP0700

STP0710

STP0720

STP0730

STP0740

STP0750

STP0760

STP0770

STP0780

STP0790

STP0 800

STP0810

STP0 820

STP0 830

STP0 840

STP0850

STP 8860

STP 0870

STP 0880

STP0 890

STP0900

STPO910

STPO920

STP0930

STP0940

STP0950

STP0960

STP0970

STP0980

STP0990

STP 1000

STP 1010

STP 1020

STP 1030

STP 1040

STP 1050

STP 1060

STP 1070

STP 1080

STP 1090

STP 1100

STP 1110

STP 1120

STP 1130

STP 1140 
IF (KP.LT.KPER.OR. IFINAL.NE. 1) RETURN

IF (IDK2.EQ.ICHK(5)) WRITE (4) PHI, SUM,SUMP, PUMPT, CFLUXT, QRET, CHSTSTP1160

1, CHDT, FLUXT, STORT, RLFLXT, FLXNT

STP 1170

$\mathrm{C}$ --- PUNCHED OUTPUT---

$130 \mathrm{IF}$ (IPU2.NE. ICHK(9)) GO TO 160 STP 1180

STP 1190

IF (IERR.EQ.2) GO TO 140

STP 1200

WRITE $(7,230)$ SUM, SUMP, PUMPT, CFIUXT, RRET, CHST, CHDT, FLUXT, STORT, ETFSTP1220

$1 \mathrm{LXT}, \mathrm{FLXNT}$

140 DO $150 \mathrm{~K}=1, \mathrm{KO}$

DO $150 \quad I=1, I 0$

150 WRITE $(7,220) \quad(P H I(I, J, K), J=1, J 0)$

160 IF (IERR.EQ.2) STOP

RETURN

C
C
C
C

-- FORMATS-D-

STP 1230

STP 1240

STP 1250

STP 1260

STP 1270

STP 1280

STP 1290

$\operatorname{STP} 1300$

STP 1310

STP 1320

STP 1330

170 FORMAT $\left(0^{\circ}, I 4,18 F 7.2 /(5 X, 18 F 7.2)\right)$

$\operatorname{STP} 1340$

180 FORMAT ('OMAXIMUM HEAD CHANGE FOR EACH ITERATION:',' ',39('-1)/('OSTP1350 $1 \cdot, 10 \mathrm{~F} 12.4)$ )

190 FORMAT ('1',55X,'HEAD MATRIX, LAYER',I3/56X,21('-'))

STP 1360

STP 1370

200 FORMAT ('1',55X,' DRAWDOWN, LAYER', I3/59X,18('-'))

STP 1380

210 FORMAT (1H1,44X,57('-')/45X,'/',14X,'TIME STEP NUMBER =',I9, 14X,'ISTP1390 $1, / 45 X, 57(-1) / / 50 X, 29$ HSIZE OF TIME STEP IN SECONDS=,F14.2//55X,"TOSTP1400 2TAL SIMUIATION TIME IN SECONDS=', F 14.2/80X,8HMINUTES=, F $14.2 / 82 X, 6$ HSTP1410 3 HOURS $=, F 14.2 / 83 X, 5$ HDAS $=, F 14.2 / 82 X,{ }^{\prime}$ YEARS $=$ ?, F $14.2 / / / 45 X, '$ DURATION STP1420 $40 F$ CURRENT PUMPING PERIOD IN DAYS =', F $14.2 / 82 \mathrm{X}$, 'YEARS =', F 14.2//)

STP 1430 STP 1440

220 FORMAT (10F8.4)

230 FORMAT (4G20.10)

240 FORMAT ("OTIME STEP:",40I3)

250 FORMAT ('OITERATIONS:', 40I3)

260 FORMAT (', $\left.\left.10\left(^{\prime}\right)^{\prime}\right)\right)$

STP 1450

STP 1460

STP 1470

END

STP 1480

STP 1490 
SUBROUTINE SOLVE(PHI, STRT, OLD,T, S,TR,TC,TK, WELI, DELX, DELY, DELZ, FACSP3O010 $1 T, E L, F L, G L, V, X I, T E S T 3, Q R E, B O T T O M$, $S P 30020$ 2PERM,IDR, RH, RC, RB, IRIV) $S P 30030 *$

SPECIFICATIONS : $S P 30060$ SP 30070 $S P 30080$ REAL *8PHI, RHO, B, D, F, H, Z, SU, RHOP,W, WMIN, RHO1, RHO2, RHO3, XPART, YPARTSP 30090 $1, Z P A R T, D M I N 1$, WMAX, XT, YT, ZT, DABS, DMAX 1, DEN, TXM, TYM, TDEN SP 30100 REAL * $8 E, A L, B I, C I, A, C, G, W U, T U, U, D L, R E S, S U P H, G I X I, Z P H I$

SP 30110 SP 30120

DIMENSION PHI(1), STRT(1), OLD(1), T(1), S(1), TR(1), TC(1), TK(1)SP301.30 1, WELL(1), DELX(1), DELY(1), DELZ(1), FACT(K0,3), RHOP(20), TEST3(SP30140 21), EL(1), FL(1), GL(1), V(1), XI(1), QRE(1), BOTTOM(1) $3, \operatorname{PERM}(1), \operatorname{IDR}(1), \mathrm{RH}(1), \mathrm{RC}(1), \mathrm{RB}(1)$ DIMENSION IN $(36,59,7), \operatorname{TT}(36,59,6), \operatorname{DBOT}(36,59), \operatorname{ISEA}(36,59)$ SP 30150 $2, \operatorname{DTOP}(9), \operatorname{IAA}(30)$, HEDSTR $(10), \operatorname{BTM}(36,59), \operatorname{KCHOP} 2(9), \operatorname{IFNLHD}(36,59,7), \operatorname{TSP} 30180 *$ 3 DEN ( 8)

COMMON /INTEGR' IO,JO,KO,I1,J1,K1,I,J,K,NPER,KTH,ITMAX,LENGTH,KP,NSP30200 1 WEL, KUMT, IFINAI, IT, KT, IHEAD, IDRAW, IFLO, IERR, I2, J2, K2, IMAX, ITMX1, KCSP 30210 $2 \mathrm{H}, I D K 1, I D K 2$, IWATER, IQRE, IP, JP, IQ, JQ, IK, JK, $\mathrm{J} 5, I P U 1, I P U 2, I T K, I E Q N$ 3, NKODE, KFLOW COMMON /SPARAM/ TMAX,CDLT,DELT,ERR,TEST, SUM, SUMP, QR,BETA 1 COMMOK /SARRAY/ ICHK(13), LEVEL1(9), LEVEL2 ( 9 ) RETURN

$S P 30500$

SP 30510

SP 30520

SP 30530

SP 30540

SP 30550

IF (K.NE. 1) $Z=I K(N-N I J) / D E I Z(K)$

SP 30560 
10 CONTINUE

$T X M=D M A X 1(D, F)$

$T Y M=D M A X 1(B, H)$

$T Z M=D M A X 1(S U, Z)$

$D E N=D M I N 1(D, F)$

IF (DEN.EQ.O.DO) DEN $=T X M$

IF (DEN.EQ.0.DO) GO TO 20

RHO 1 $=$ DMAX $1($ RHO I , TYM/DEN $)$

$20 D E N=D M I N 1(B, H)$

IF (DEN.EQ.O.DO) DEN=TYM

IF (DEN.EQ.O.DO) GO TO 30

SP 30580

SP 30590

SP30600

SP 30610

SP 30620

SP 30630

SP 30640

SP 30650

SP 30660

RHO2 $=$ DMAX $1($ RHO2 $; \mathrm{T} X M / D E N)$

SP 30670

SP 30680

$30 \mathrm{DEN}=\mathrm{DMIN} 1(\mathrm{SU}, \mathrm{Z})$

IF $(D E N, E Q .0 . D O) \quad D E N=T Z M$

SP 30690

IF (DEN.EQ.O.DO) GO TO 40

SP 30700

SP 30710

RHO3 $=$ DMAX $1($ RHO3,$T X M / D E N)$

SP 30720

40 CONTINUE

$X P A R T=X T /(1 . D O+R H O 1)$

$Y P A R T=Y T /(1 . D O+R H O 2)$

$\mathrm{ZPART}=\mathrm{ZT} /(1 . \mathrm{DO}+\mathrm{RHO3})$

SP 30730

SP 30740

SP 30750

SP 30760

WMIN $=$ DMIN ( (WMIN, XPART, YPART, ZPART )

SP 30770

WMAX $=1$. DO-WMIN

$\mathrm{PJ}=-1$.

SP 30780

SP 30790

DO $50 I=1$, LENGTH

$P J=P J+1$.

SP 30800

SP 30810

SP 30820

SP 30830

SP 30840

WRITE $(6,230)$ LENGTH, $(R H O P(J), J=1, \operatorname{LENGTH})$

SP 30850

c TURN

SP 30860

SP 30870

$60 I T=I T+1$

C

PRINT HEAD VALUES FOR SEIECTED NODES

SP 30880

SP 30890

SP 30900

SP 30910

$I T T=T-1$

IF(NODKOD.NË.1) GO TO 68

IF (ITT.IT.1) WRITE(6,2970) (IAA(I), I=1, MNOD)

$J=1$

DO $64 I=3, M N O D, 3$

$\mathrm{N}=\operatorname{IAA}(I-2)+(\operatorname{IAA}(I-1)-1) * I 0+(\operatorname{IAA}(I)-1) * N I J$

HEDSTR $(J)=P H I(N)$

$J=J+1$

64 CONTINUE

WRITE $(6,2980) \operatorname{ITT},(\operatorname{HEDSTR}(J), J=1, \operatorname{NMBRND})$

C

68 IF (IT.IE.ITMAX) GO TO 70

WRITE $(6,220)$

CAIL OUTPIT

70 IF (MOD(IT, IENGTH)) $80,80,90$

c

$* * * * * * * * * * * * * * * * * * * * *$

ENTRY NEWITA

C

$* * * * * * * * * * * * * * * * * * * * *$

$80 \mathrm{NTH}=0$

$90 N T H=N T H+1$

$W=$ RHOP $(\mathrm{NTH})$

$\operatorname{TEST} 3(I T+1)=0$.

SP 30920

SP 30930*

SP 30940*

SP 30950*

SP $30960 *$

SP $30970 *$

SP $30980 *$

SP $30990 *$

SP $31000 *$

SP 31010*

SP 31020

SP 31030

SP 31040

SP 31050

SP 31060

SP 31070

SP 31080

SP 31090

SP 31100

SP 31110

SP 31120

SP 31130 
$T E S T=0.0$

SP31140

$B I G=0$.

DO $100 \quad I=1, N T$

SP 31150

$E L(I)=0$.

$F I(I)=0$.

$G L(I)=0$.

$V(I)=0$.

c

c

$100 \times I(I)=0$.
SP31160

SP 31170

SP 31180

SP 31190

SP 31200

SP 31210

SP 31220

SP 31230

SP 31240

$S P 31250$

SP 31260

SP 31270

SP 31280

SP 31290

SP 31300

SP 31310

SP 31320

SP 31330

SP 31340

SP 31350

SP 31360

SP 31370

SP 31380

SP 31390

SP 31400

SP 31410

SP 31420

SP 31430

SP 31440

SP 31450

SP 31460

SP 31470

SP 31480

SP 31490

SP 31500

SP 31510

SP 31520

SP 31530

SP 31540

SP 31550

SP 31560

SP 31570

SP 31580

SP 31590*

SP $31600 *$

SP $31610 *$

SP $31620 *$

SP31630*

SP $31640^{*}$

SP $31650 *$

SP 31660* SP31670* SP31680* SP 31690 * SP $31700 *$ 


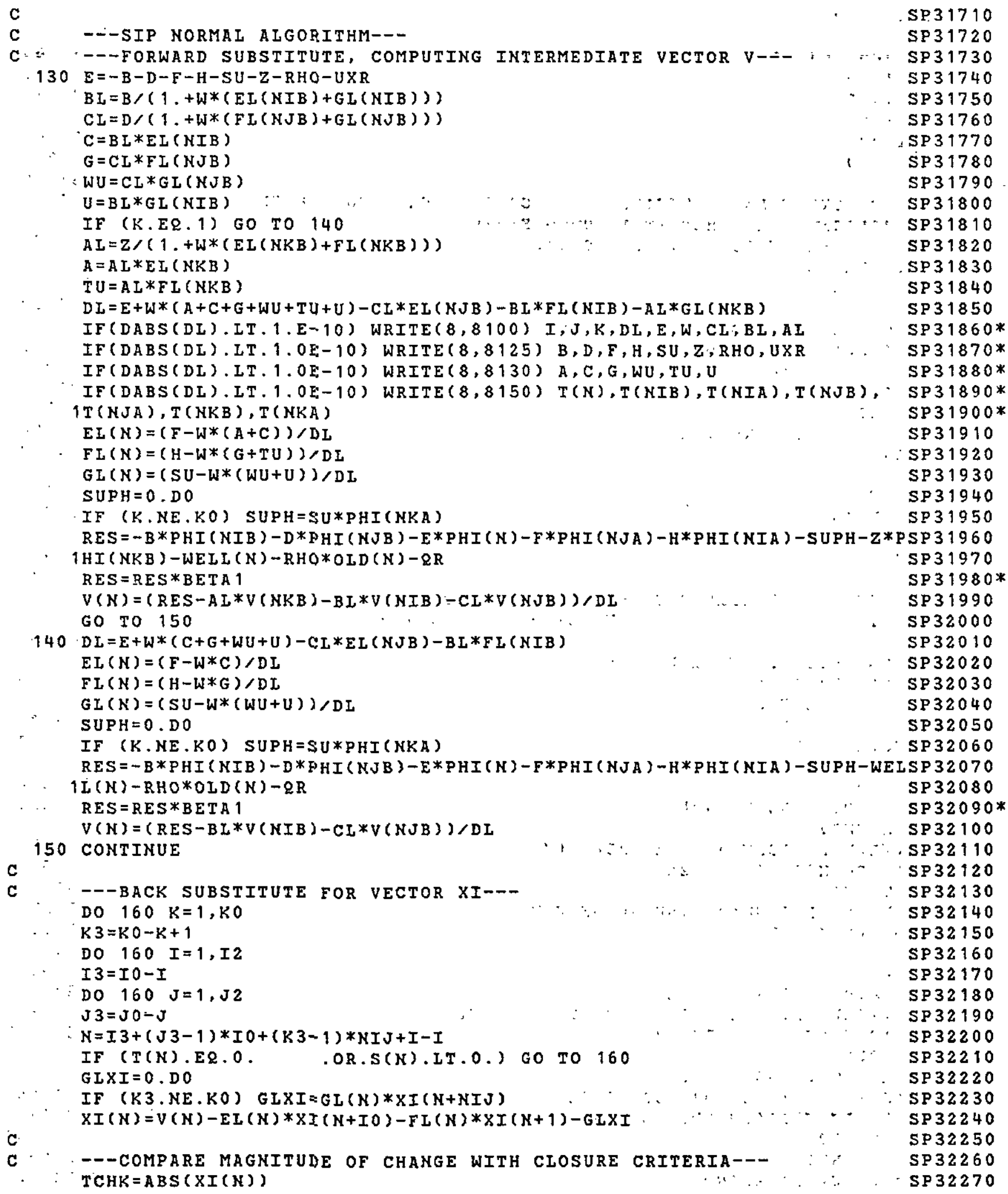


IF ( TCHK.GT.BIG) BIG $=$ TCHK

$S P 32280$

$P H I(N)=P H I(N)+X I(N)$

1.60 CONTINUE

IF (BIG.GT.ERR) TEST $=1$.

TEST $3(I T+1)=B I G$

$\mathrm{C}$
$\mathrm{C}$
$\mathrm{C}$
$\mathrm{C}$
$\mathrm{C}$
$\mathrm{C}$

---GROUP I CARDS---

CHECK IF THIS IS FIRST TIME STEP OF FIRST PUMPING PERIOD.

IF NOT SKIP THIS SECTION.

IF (KP.GT.1) GO TO 2090

IF (KT.GT.1) GO TO 2090

SP32290

SP 32300

SP 32310

SP 32320

SP $32330 *$

SP32340*

SP 32350*

SP 32360*

SP 32370*

SP $32371 *$

SP 32380*

SP $32385 *$

SP 32390*

C

CHECK IF THIS IS FIRST SOLUIION. IF IT IS PROCEED WITH INITIAL CHECKS IF(IT.NE.0.) GO TO 2090

INTERFACE DEFINITION: DEFINE PARAMETERS, READ DATA, INITIALIZE IN ARRAY AND PERFORM FIRST CHOP

SP $32410 *$ SP32420* SP $32430 *$ SP 32440* SP 32450* SP 32460*

\section{DEFINITION OF PARAMETERS}

NTAD = NUMBER OF ITERATIONS BETWEEM T ADJUSTMENTS

DBOT $(I, J)$ = BASE OF ARUIFER SYSTEM IN TERMS OF + NUMBERS BECAUSE $\mathrm{Z}$ IS + DOWNWARD

RF = COEFFICIENT OF PHI TO GIVE INTERFACE DEPTH BELOW SEA LEVEL $=($ (RHOS - RHOF $) / R H O F)$

DTOP $(K)=$ DEPTH BELOW SEA LEVEL TO TOP OF LAYERS IN TERMS OF + NUMBERS BECAUSE $z$ IS + DOWNWARD

$Z 2=$ DISTANCE TO TOP OF F.D. BLOCK BELOW SEA LEVEL

IH $=$ IO/2 FOR TWO-SIDED CHOP, = II FOR ONE-SIDED CHOP (E.G. CROSS SECTIONS)

$z=$ DEPTH BELOW S.L. TO INTERFACE

IN $=4=$ BIOCK WITH ADJUSTED T

$=6=$ BLOCK DROPPED DURING CHOP

$=7$ = BLOCK DROPPED BECAUSE OCEAN LEAKAGE INTO AQUIFER

$=8=$ INITIAL $T=0$

KODCHP = CODE TO INDICATE WHETHER CHOPPING SHOULD PROCEED FROM TWO SIDES OR ONE ( 1 =ONE-SIDED, NE $1=$ TWO-SIDED)

READ AND WRITE INPUT DATA

READ (5,2901) NTAD,RF, KODCHP,KPRNTT

WRITE $(6,2902)$ NTAD,RF, KODCHP, KPRNTT

c

READ AND PRINT AQUIFER BASE

READ (5,2909) FAC, IVAR, IPRN

IF(IVAR.NE.1) GO TO 2002

DO $2001 I=1, I 0$

$2001 \operatorname{READ}(5,2903) \quad(D B O T(I, J), J=1, J 0)$

2002 DO $2004 I=1, I 0$

DO $2004 \mathrm{~J}=1, \mathrm{~J} 0$

IF(IVAR,NE. 1) GO TO 2003

$\mathrm{DBOT}(I, J)=\mathrm{DBOT}(I, J) * F A C$

GO TO 2004

2003 DBOT $(I, J)=F A C$

2004 CONTINUE

IF(IPRN.EQ.1) GO TO 2006

SP 32470*

SP $32480 *$

SP 32490*

SP $32500 *$

SP 32510*

SP 32520*

SP 32530*

SP $32540 *$

SP 32550*

SP32560*

SP 32570*

SP 32580*

SP 32590*

SP $32600^{*}$

SP32610*

SP $32620 \%$

SP 32630*

SP 32640*

SP $32650 *$

SP 32660*

SP32670*

SP 32680*

SP 32690*

SP 32700*

SP $32710 *$

SP 32720*

SP $32730 *$

SP 32740*

SP 32750*

SP32760*

SP 32770*

SP32780*

SP $32790 *$

SP $32800 *$

SP32810*

SP $32820 *$

$-101=$ 
WRITE $(6,2904)$

DO $2005 I=1, I 0$

2005 WRITE $(6,2905) I,(D B O T(I, J), J=1, J 0)$

C

C READ AND PRINT CONSTANT HEAD OCEAN NODES

DO $2007 I=1, I 0$

$2007 \operatorname{READ}(5,2906)(\operatorname{ISEA}(I, J), J=1, J 0)$

WRITE $(6,2907)$

DO $2008 I=1, I 0$

2008 WRITE $(6,2908) \quad I,(\operatorname{ISEA}(I, J), J=1, J 0)$

C

C READ AND PRINT DEPTH TO LAYER TOPS

$\operatorname{READ}(5,29 J 9)(\mathrm{DTOP}(\mathrm{K}), K=1, K O)$

DO $2010 \mathrm{~K}=1, \mathrm{KO}$

2010 WRITE $(6,2910) \mathrm{K}, \mathrm{DTOP}(\mathrm{K})$.

C READ NODES FOR WHICH HEAD VALUES AT EACH TTERATION ARE TO BE PRINTED SP32980* READ (5,2909) NODKOD, NMBRND

IF (NODKOD.NE.1) GO TO 2012

MNOD $=3$ * NMBRND

$\operatorname{READ}(5,2960)(\operatorname{IAA}(I), I=1, \operatorname{MNOD})$

C

C READ NODES FOR WHICH FINAL HEADS ARE TO BE PRINTED INDIVIDUALIY

2012 READ $(5,2909)$ THEDKD

IF(IHEDKD.NE. 1) GO TO 2014

DO $2013 \mathrm{~K}=1, \mathrm{KO}$

DO $2013 \quad I=1, I 0$

2013 READ $(5,2906)$ (IFNLHD $(I, J, K), J=1, J 0)$

C CHECK IF INTERFACE SOLUTION

IF NOT SKIP THIS SECTION 2014 IF(NKODE.NE.1) GO TO 2095

c

c

C INITIALIZE IN,T', AND SCALARS

$I H=I O / 2$

IF (KODCHP.EQ.1) IH=I 1

$N I J=I O * J O$

$\mathrm{KCHOP} 2(\mathrm{KO})=0^{\circ}$

DO $2015 \mathrm{~K}=1, \mathrm{~K} 1$

$\mathrm{KCHOP} 2(K)=0$

DO $2015 I=1, I 0$

DO $2015 \mathrm{~J}=1, \mathrm{~J} 0$

$N=I+(J-1) * I 0+(K-1) * N I J$

$I N(I, J, K)=0$

$20.15 T T(I, J, K)=T(N)$

C

DO $2017 I=1, I 0$

DO $2017 \mathrm{~J}=1, \mathrm{~J} 0$

$I N(I, J, K O)=0$

$M=I+(J-1) * I 0$

$2017 \operatorname{BTM}(I, J)=$ BOTTOM (M)

C NORTH SIDE CHECK

C

DO $2026 K=1, K O$

DO $2025 \mathrm{~J}=2, \mathrm{~J} 1$

DO $2020 I=2$, IH

$\mathrm{N}=I+(J-1) * I 0+(K-1) * N I J$

SP32830*

SP $32840 *$

SP $328.50 *$

SP32860*

SP32870*

SP $32880 *$

SP $32890 \%$

SP $32900 *$

SP $32910 *$

S SP32920*

SP 32930*

SP 32940*

SP $32950 *$

SP 32960*

SP 32970*

SP $32990 *$

SP $33000 *$

SP $33010 *$

SP 33020*

SP $33030 *$

sP $33040 *$

SP 33050*

SP $33060 *$

SP 33070*

SP $33080 *$

SP $33090 \%$

SP33100*

SP $33110 *$

SP 33120*

SP 33130*

SP 33140*

SP $33150 *$

SP $33160 *$

SP $33170 *$

SP $33180 *$

SP $33190 \%$

SP $33200 *$

SP $33210 \%$

SP $33220 *$

SP $33230 \%$

SP 33240*

SP 33250*

SP $33260 *$

SP 33270*

SP $33280 \%$

SP $33290 \%$

SP $33300 *$

SP $33310 *$

SP 33320*

SP $33330 \%$

SP $33340 *$

SP 33350*

SP 33360*

SP $33370 *$

SP $33380 *$

SP $33390 *$ 


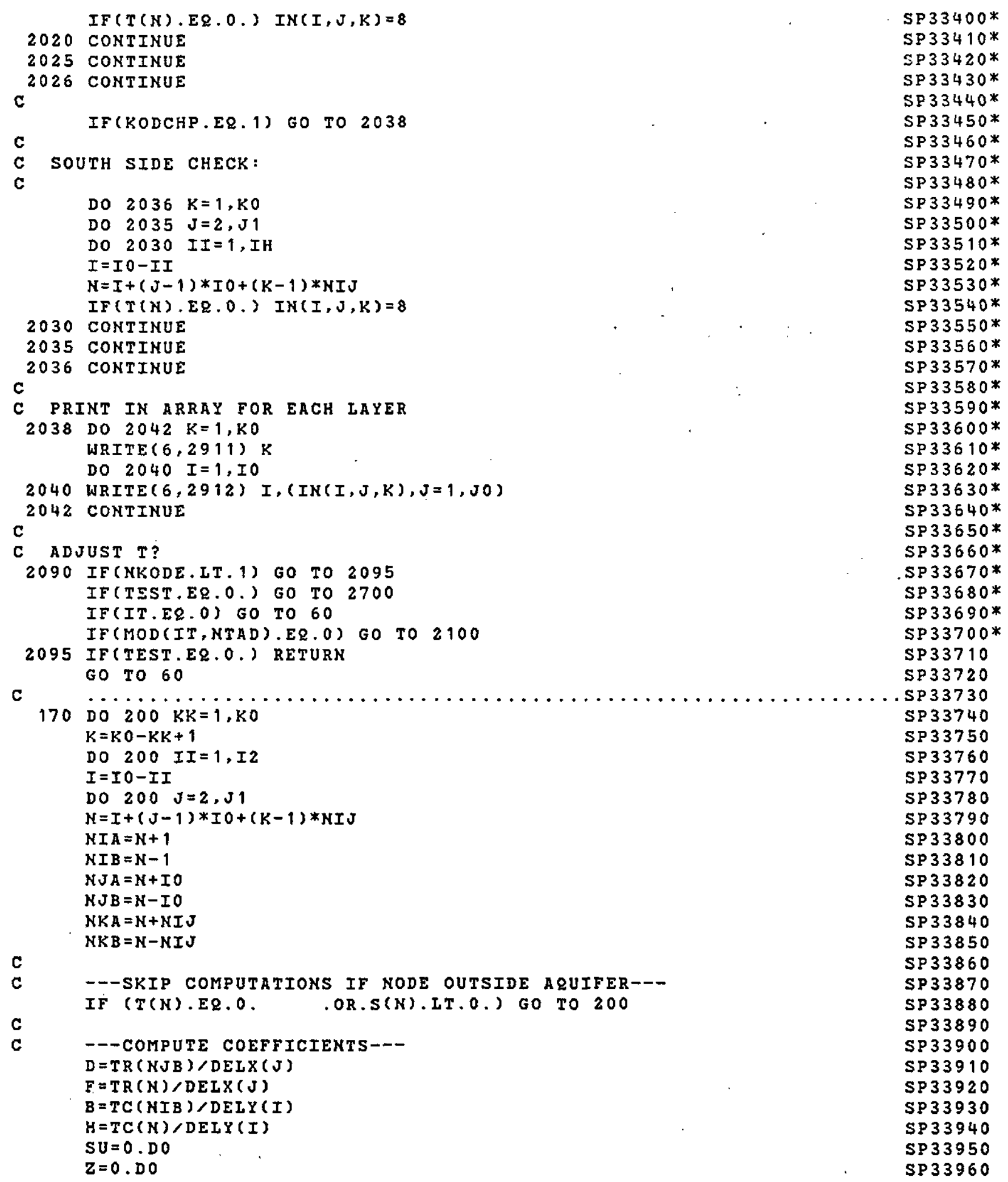


IF (K.EQ. 1) GO TO 174

SP33970

$\mathrm{Z}=\mathrm{TK}(\mathrm{NKB})$

IF (IEQN.EQ. ICHK( 11$)) \quad \mathrm{Z}=\mathrm{Z} / \mathrm{DEL} \mathrm{Z}(\mathrm{K})$

SP 33980

SP 33990

SP 34000

SP 34010

$\mathrm{SU}=\mathrm{T} K(N)$

IF (IEQN . EQ. ICHK (11)) SU =SU/DELZ (K)

SP 34020

SP 34030

SP $34040 *$

$Q R=0$.

$\mathrm{UXR}=0$.

IF (K.NE.KO) GO TO 177

IF (IQRE.EQ.ICHK(7)) $2 R=2 R E(I+(J-1) * I 0)$

SP $34050 *$

SP34060*

SP $34070 *$

SP 34080*

SP $34090 *$

SP $34100 *$

IF (ND.EQ.O) GO TO 180

$I F(P H I(N) . G T . R B(N D))$ GO TO 178

$Q R=Q R+R C(N D) *(R H(N D)-R B(N D))$

SP $34110 *$

SP 34120*

GO TO 180

$178 U X R=R C(N D)$

$Q R=Q R+R C(N D) * R H(N D)$

SP $34130 *$

SP $34140 *$

SP $34150 *$

SP 34160

- - SIP REVERSE ALGORITHM- -

-- FORWARD SUESTITUTE, COMPUTING INTERMEDIATE VECTOR V--

SP 34170

SP 34180

SP34190

SP 34200

$B L=H /(1 .+W *(E L(N I A)+G I(N I A)))$

$S P 34210$

$C L=D /\left(1 .+W^{*}(F I(N J B)+G L(N J B))\right)$

$C=B L * E L(N I A)$

$G=C L * F L(N J B)$

$W U=C L * G L(N J B)$

$U=B L * G L(N I A)$

IF $(K . E Q . K O)$ GO TO 190

$A L=S U /(1 .+W *(E L(N K A)+F L(N K A)))$

$A=A L * E L(N K A)$

$T U=A L * F L(N K A)$

$D L=E+W *(C+G+A+W U+T U+U)-A L * G L(N K A)-B L * F L(N I A)-C L * E L(N J B)$

IF(DABS(DI).LT.1.E-10) WRITE ( 8,8200) I,J,K,DL,E,W,CL,BI, AI

IF (DABS (DL).IT. 1.OE-10) WRITE $(8,8125)$ B, D,F,H,SU,Z,RHO,UXR

SP 34220

SP 34230

$S P 34240$

SP 34250

SP 34260

SP 34270

SP 34280

SP 34290

SP 34300

SP $34310 *$

SP $34320 *$

$\operatorname{IF}(D A B S(D L) . I T \cdot 1.0 E-10)$ WRITE $(8,8130) A, C, G, W U, T U, U$

IF (DABS(DL).IT.1.0E-10) WRITE $(8,8150) T(N), T(N I B), T(N I A), T(N J B)$,

$\operatorname{SP} 34330 *$

SP $34340 *$

$1 \mathrm{~T}(\mathrm{NJA}), \mathrm{T}(\mathrm{NKB}), \mathrm{T}(\mathrm{NKA})$

$E I(N)=(F-W *(C+A)) / D L$

$F L(N)=(B-W *(G+T U)) / D I$

SP $34350 *$

SP 34360

SP 34370

$G L(N)=(Z-W *(W U+U)) / D I$

SP 34380

$\mathrm{ZPHI}=0 . \mathrm{DO}$

SP 34390

IF (K.NE.1) ZPHI $=\mathrm{Z} * \mathrm{PHI}(\mathrm{NKB})$

SP 34400

RES $=-B * P H I(N I B)-D * P H I(N J B)-E * P H I(N)-F * P H I(N J A)-H * P H I(N I A)-S U * P H I(N S P 34410$

1KA) -ZPHI-WELL (N)-RHO*OLD $(N)-2 R$

$\mathrm{RES}=\mathrm{RES} * \mathrm{BETA} 1$

$\cdot V(N)=(R E S-A L * V(N K A)-B L * V(N I A)-C I * V(N J B)) / D L$

SP 34420

SP $34430 *$

SP 34440 GO TO 200

$190^{\circ} D L=E+W *(C+G+W U+U)-B L * F L(N I A)-C L * E L(N J B)$

$E L(N)=(F-W * C) / D I$

$F L(N)=(B-W * G) / D I$

$G I(N)=(z-W *(W U+U)) / D L$

ZPHI $=0$. DO

IF (K.NE.1) ZPHI=Z*PHI(NKB)

SP 34450

SP 34460

SP 34470

SP 34480

SP 34490

SP 34500

SP 34510

RES $=-B * P H I(N I B)-D * P H I(N J B)-E * P H I(N)-F * P H I(N J A)-H * P H I(N I A)-Z P H I-W E I S P 34520$

iL $(-N)-R H O * O L D(N)-Q R$

SP 34530 


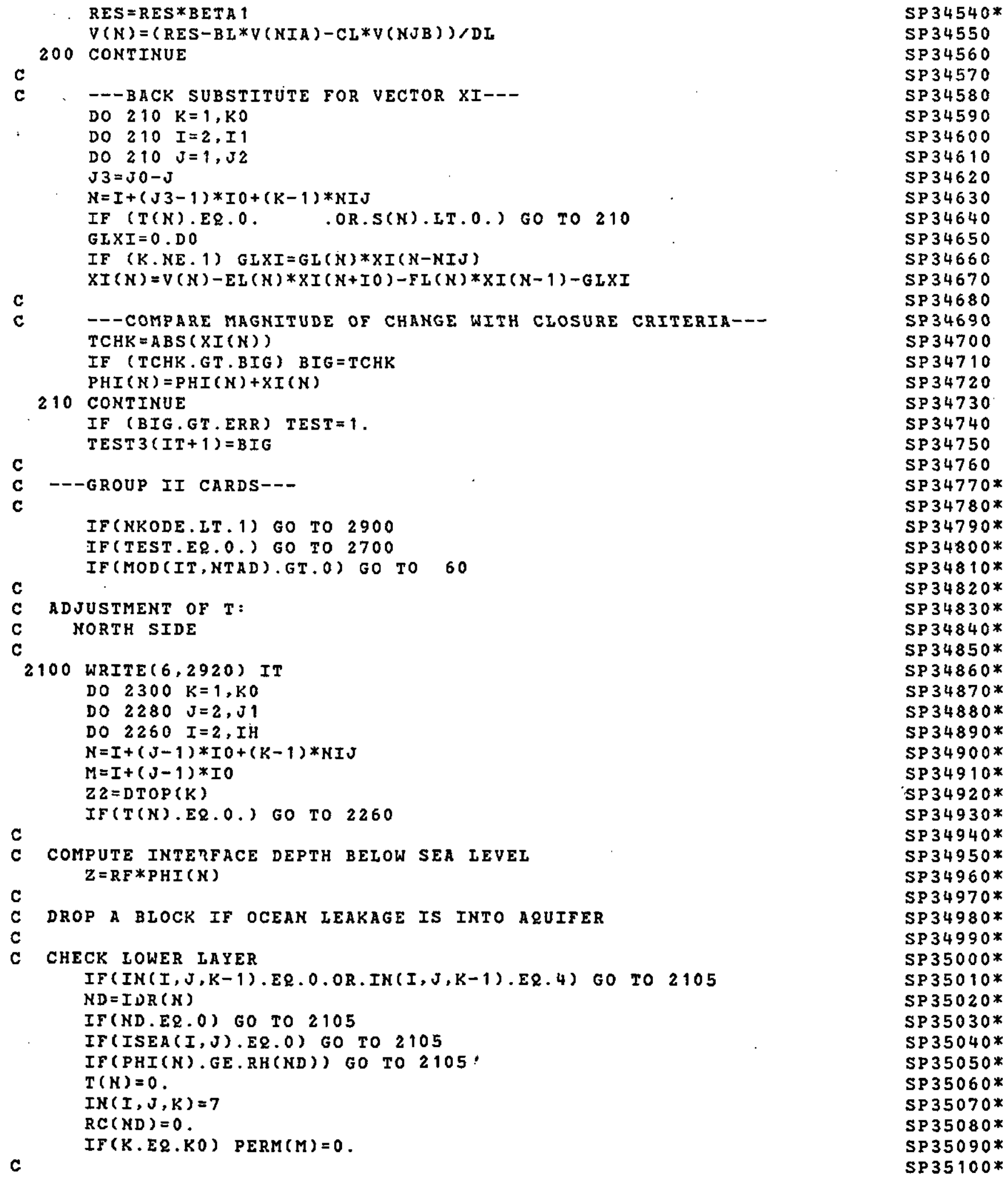

SP 34560

$S P 34570$

SP 34580

SP 34590

SP 34600

SP 34610

SP 34620

SP 34630

SP 34640

SP 34650

SP 34660

SP 34670

SP 34680

SP 34690

SP 34700

SP 34710

SP 34720

SP 34730

SP 34740

SP 34750

SP 34760

SP $34770 *$

SP 34780 * SP 34790* SP 34800* SP $34810 *$ SP $34820 *$ SP 34830* SP 34840* SP 34850* SP 34860* SP 34870* SP $34880 \%$ SP 34890* SP $34900 *$ SP 34910* SP 34920* SP 34930 * SP 34940* SP 34950* SP 34960* SP 34970* SP 34980* SP 34990* SP 35000* SP $35010 *$ SP 35020* SP $35030 *$ SP 35040\% SP 35050* SP 35060* SP 35070* SP 35080* SP 35090 * SP $35100 *$ 


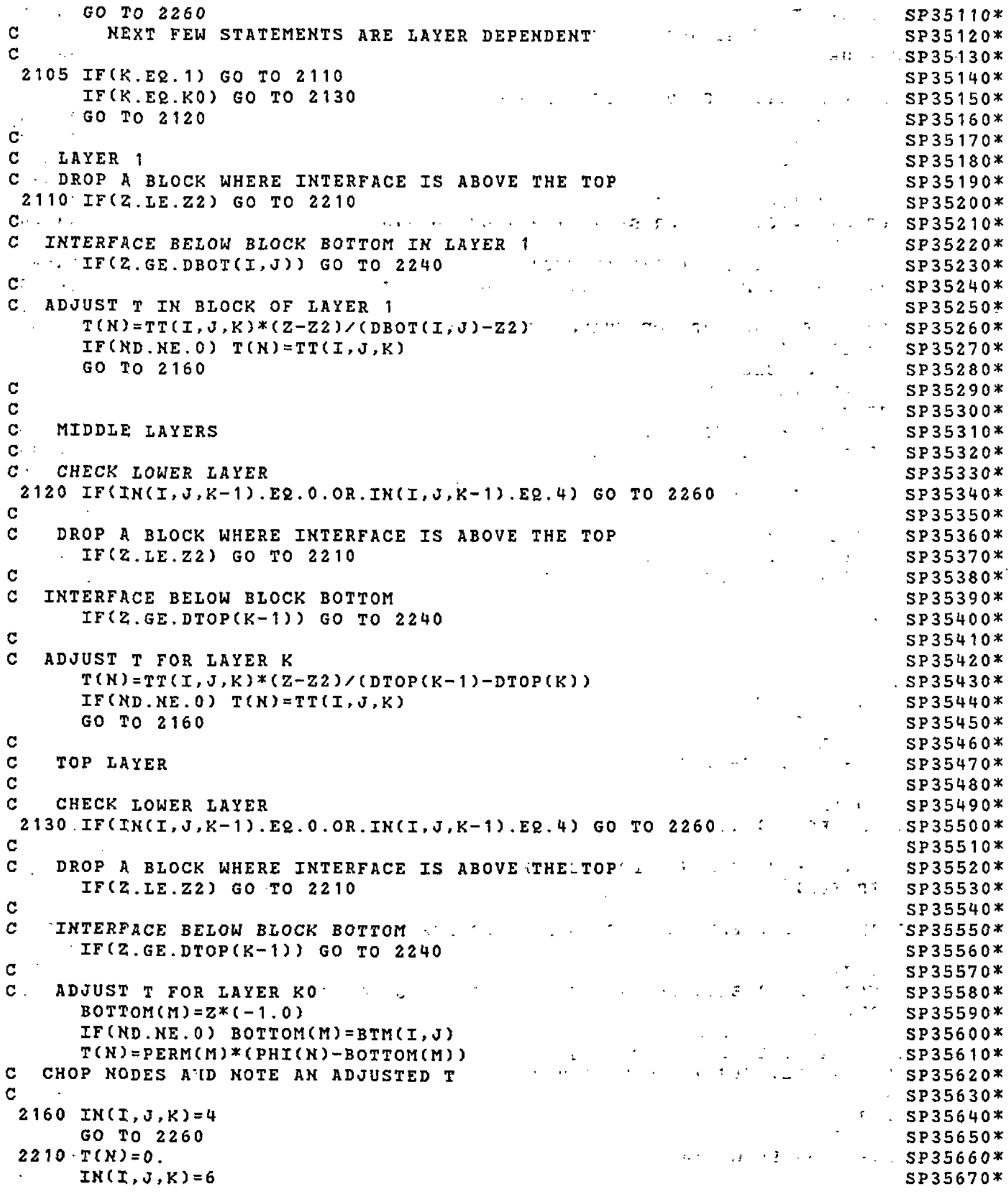




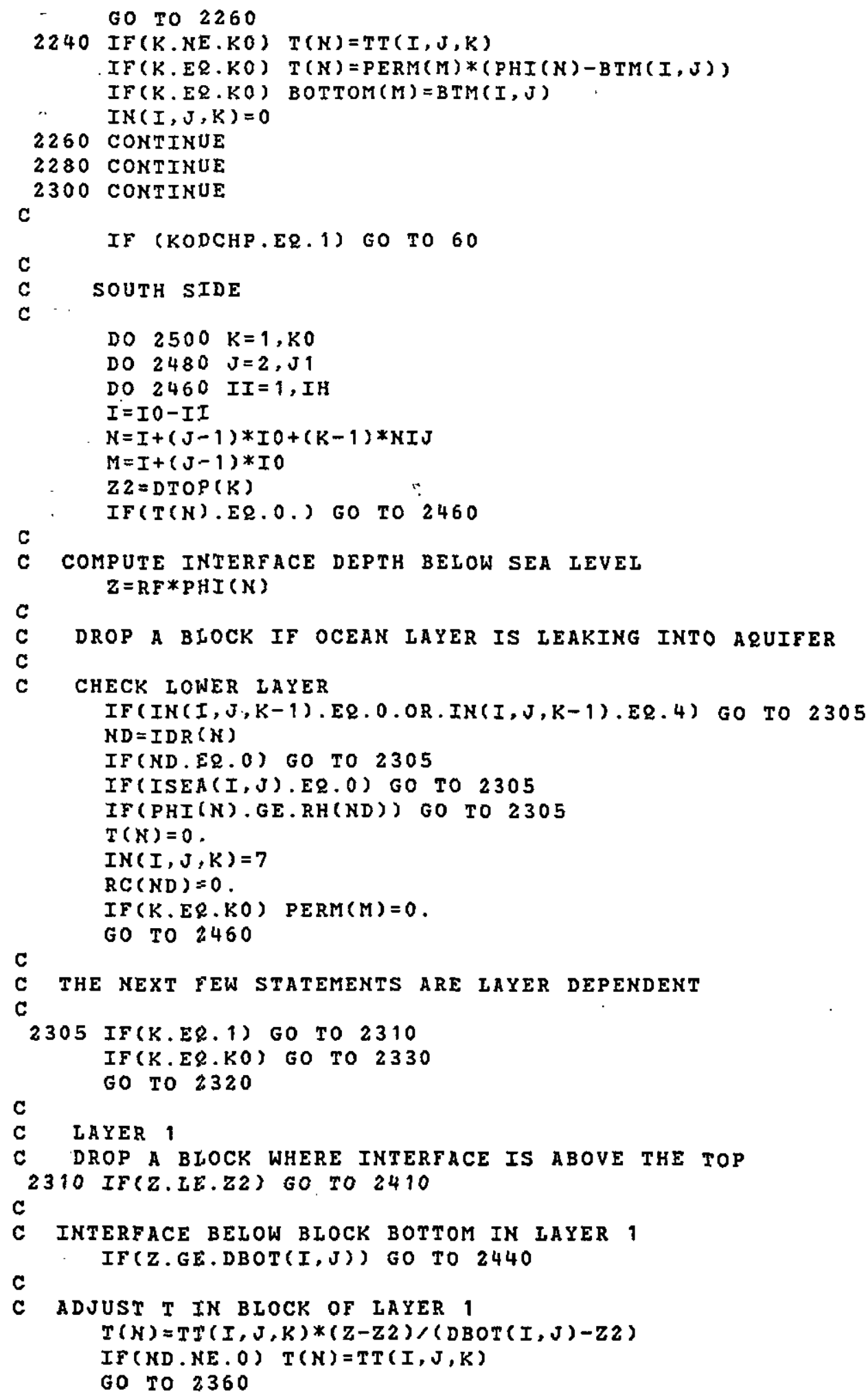




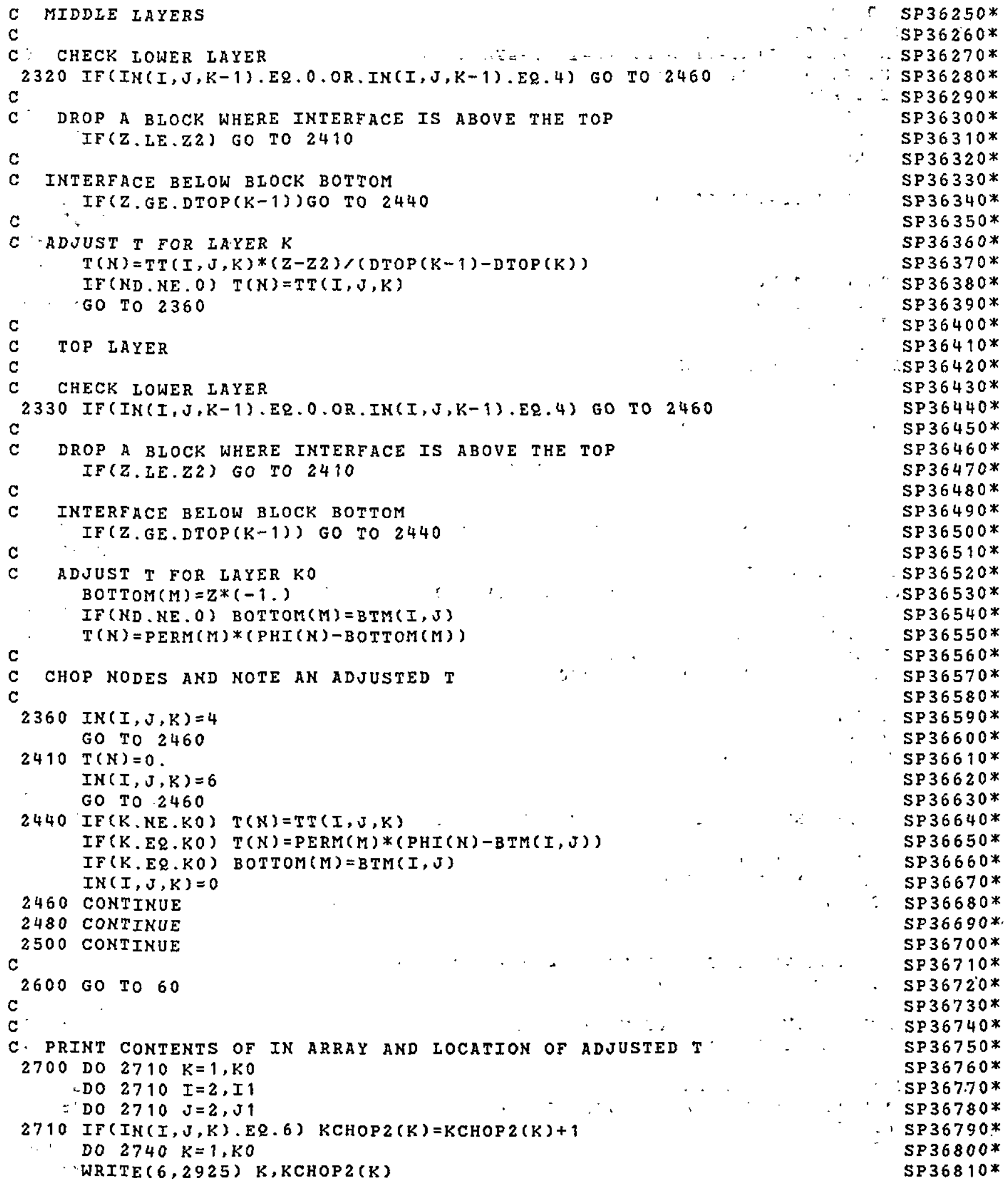


DO $2720 \quad I=1, I 0$

2720 WRITE $(6,2930) \quad I,(\operatorname{IN}(I, J, K), J=1, J 0)$

2740 CONTINUE

c

WRITE $(6,2940)$

DO $2800 \mathrm{~K}=1, \mathrm{kO}$

DO $2800 \quad I=1,10$

DO $2800 \quad J=1,50$

$N=I+(J-1) * I 0+(K-1) * N I J$

IF $(I N(I, J, K), N E .4)$ GO TO 2800

$Z=R F * P H I(N)$

WRITE(6,2950) K,I,J,Z,T(K)

2800 CONTINUE

c

C PRINT FINAL HEAD VALUES FOR SELECTED NODES IF (IHEDKD.NE. 1) GO TO 2825

WRITE $(8,2985)$

C UPPER LAYER ONIY

$\mathrm{K}=\mathrm{KO}$

DO $2820 \quad I=2, I 1$

DO $2820 \mathrm{~J}=2, \mathrm{~J} 1$

IF(IFNLHD $(I, J, K) . N E .1)$ GO TO 2820

$K=I+(J-1) * I 0+(K-1) * N I J$

WRITE $(8,2990) I, J, K, P H I(N)$

2820 CONTINUE

C ALL IAYERS

DO $2823 \mathrm{~K}=1, \mathrm{KO}$

DO $2823 \quad I=2 ; I 1$

DO $2823 \mathrm{~J}=2, \mathrm{~J} 1$

IF (IFNLHD $(I, J, K) . N E .2)$ GO TO 2823

$N=I+(J-1) * I 0+(K-1) * N I J$

WRITE $(8,2990) I, J, K, P H I(K)$

2823 CONTINUE

C

C PRINT FINAL PHI, T, PERM, AND TK MATRICES

2825 IF(KPRNTT.NE.1) GO TO 2895

IOJO $=$ IO*JO

$\mathrm{I} 1=1$

DO $2893 \quad N 1=1,3$

$\mathrm{KOA}=\mathrm{KO}$

$I F(N 1 . G T .2) K O A=K O A-1$

DO $2890 \mathrm{~K}=1, \mathrm{KOA}$

WRITE $(9,2830)$

2830 FORMAT $\left(9 \mathrm{x}, 1^{\prime}, 9 \mathrm{x}, 1^{\prime}, 9 \mathrm{x}, 0^{\prime}, 9 \mathrm{x}, 1^{\prime}, 9 \mathrm{x}, 1^{\prime}, 9 \mathrm{x}, 1^{\prime}, 9 \mathrm{x}, 0^{\prime}, 9 \mathrm{x}, 0^{\prime}\right)$

DO $2885 I=1, I 0$

DO $2880 \mathrm{~J}=1, \mathrm{~J} 0$

$N=I+(J-1) * I 0+(K-1) * I 0 J 0$

GO TO $(2835,2840,2845), \mathrm{N} 1$

$2835 \operatorname{TDEN}(\mathrm{L}\})=\mathrm{PHI}(\mathrm{K})$

GO TO 2850

$2840 I F(K . I T . K O A)$ GO TO 2843

$M=I+(J-1) * I 0$

$\operatorname{TDEN}(I 1)=\operatorname{PERM}(M)$

GO TO 2850

$2843 \operatorname{TDEN}(\mathrm{I} 1)=\mathrm{T}(\mathrm{N})$

GO TO 2850

$2845 \operatorname{TDEN}(I, 1)=\operatorname{TK}(K)$

SP $36820 \%$

SP $36830 *$

SP $36840^{*}$

SP 36850*

SP $36860^{*}$

SP $36870^{*}$

SP $36880^{*}$

SP $36890^{*}$

SP $36900 *$

SP $36910 *$

SP $36920 *$

SP $36930 *$

SP 36940*

SP $36950 \%$

SP $36960^{*}$

SP $36970 *$

SP36980*

SP $36990^{*}$

SP 37000*

SP37010*

SP $37020 *$

SP 37030*

SP 37040*

SP 37050*

SP37060*

SP $37070 \%$

S.P37080\%

SP37090*

SP $37100 *$

SP $37110 *$

SP 37120 *

SP 37130*

SP $37140 *$

SP 37145*

SP37150*

SP37160*

SP37170*

SP $37175 *$

SP $37180 *$

SP $37185 *$

SP37190*

SP 37195*

SP $37200 *$

SP 37205*

SP37210*

SP 372 15*

SP37220*

SP $37225 *$

SP $37230 *$

SP 372 35*

SP 37240*

SP 37243*

SP 37246*

SP 37250*

SP 37253*

SP37256*

SP37260* 


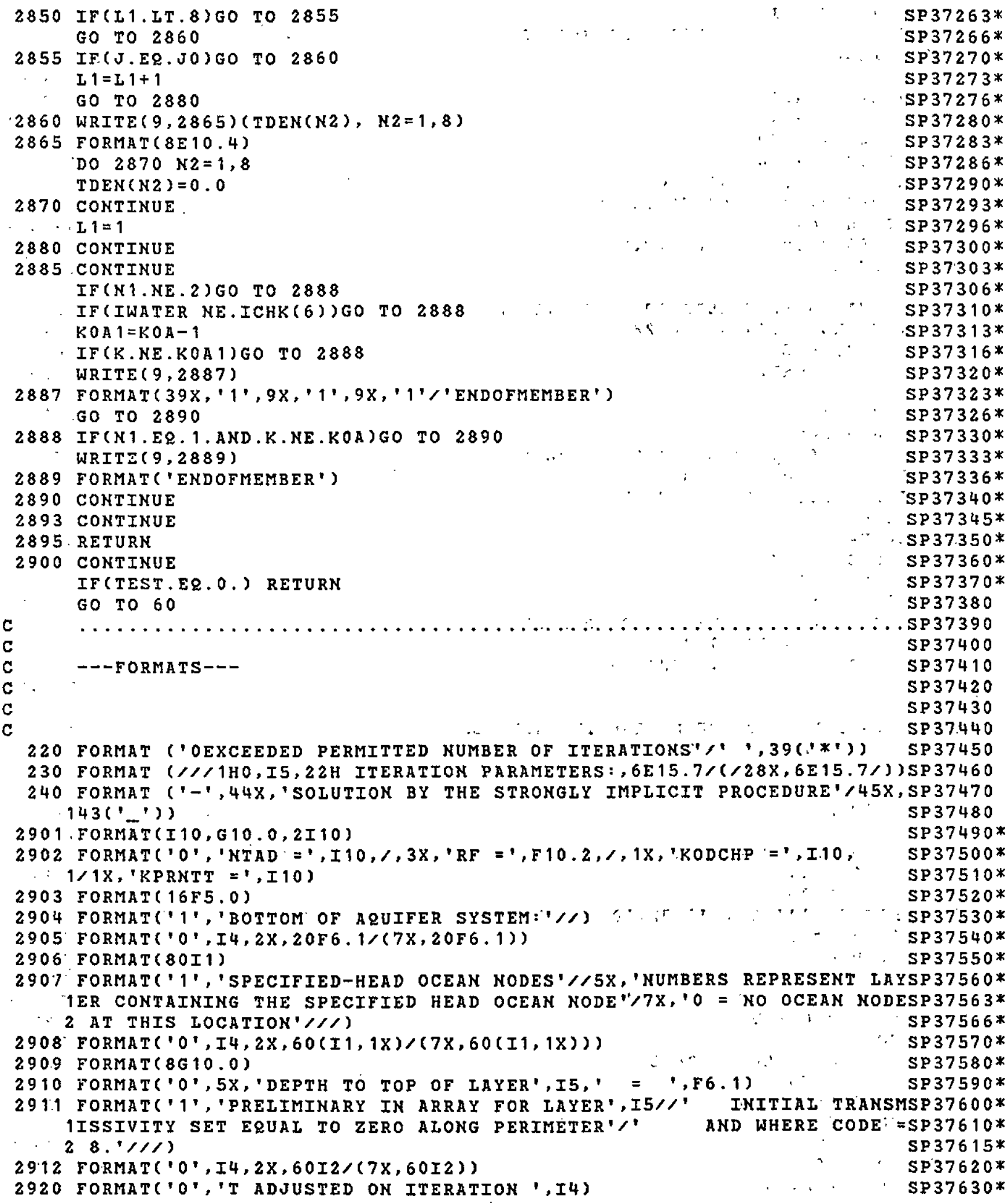




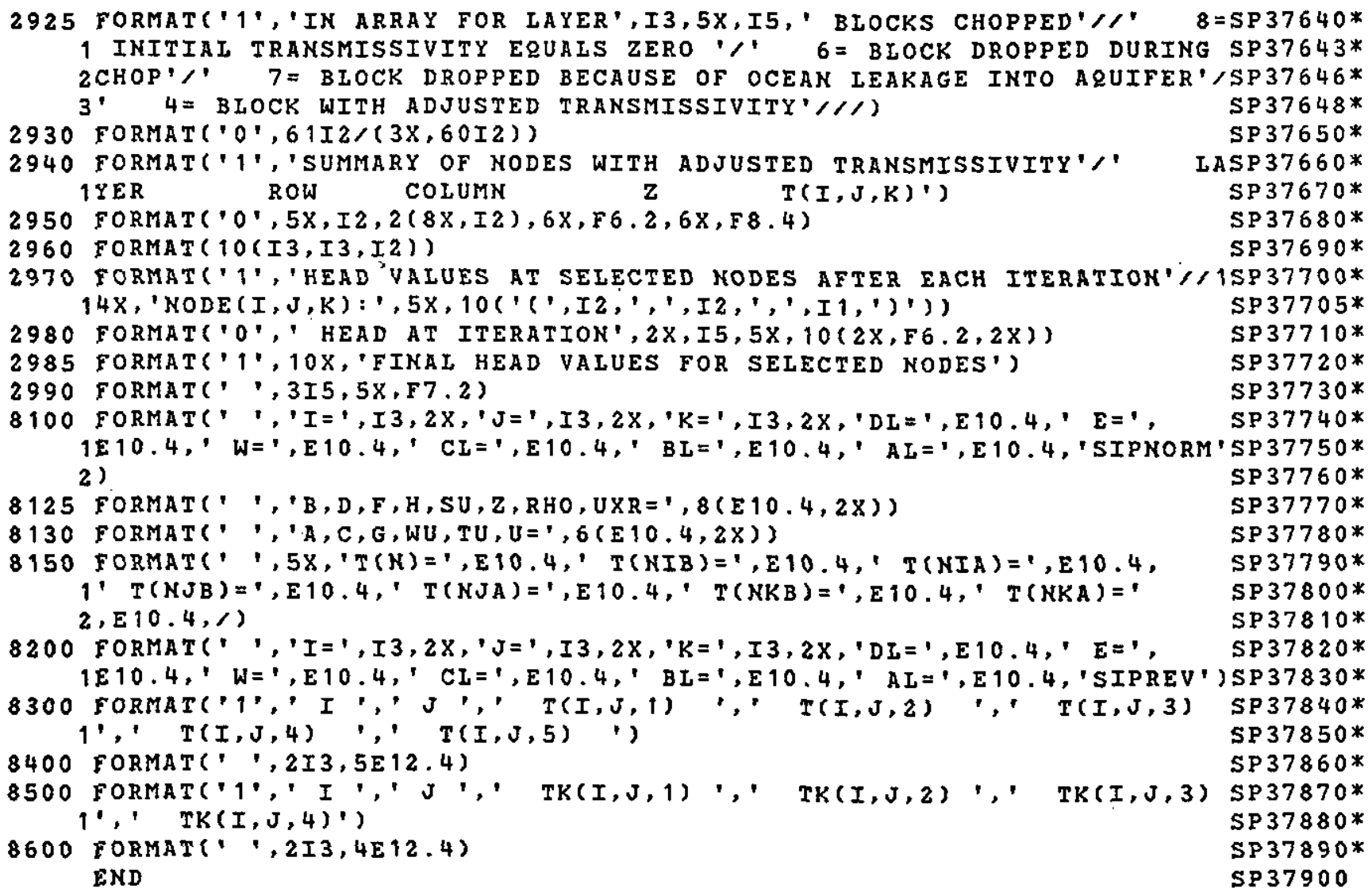


SUBROUTINE COEF(PHI, STRT, OLD,T,S,TR,TC,TK, WELL, DELX, DELY, DELZ, FÄCTCOFOO 10 1, PERM, BOTTOM, QRE)

COFOO2O

COMPUTE COEFFICIENTS

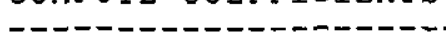

DIMENSION PHI(IO,JO,KO), STRT(IO,JO,KO), OLD(IO,JO,KO), T(IO,JO,KOCOFO100 1), $S(I 0, J 0, K O), T R(I O, J O, K O), T C(I 0, J 0, K O), T K(I K, J K, K 5)$; WEIL(IO, COFO110 $2 \mathrm{~J} 0, \mathrm{KO}), \operatorname{DELX}(\mathrm{JO}), \operatorname{DELY}(\mathrm{IO}), \operatorname{DELZ}(\mathrm{KO})$, FACT(KO,3), PERM(IP,JP), BOTCOFO120 $3 T O M(I P, J P), \quad Q R E(I Q, J Q)$

COF 0130

C

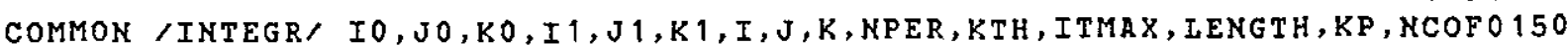
1 WEL, NUMT, IFINAL, IT, KT, IHEAD, IDRAW, IFLO, IERR, I2, J2, K2, IMAX, ITMX 1, KCCOFO 160 $2 \mathrm{H}, I D K 1, I D K 2, I W A T E R, I Q R E, I P, J P, I Q, J Q, I K, J K, K 5, I P U 1, I P U 2, I T K, I E Q K$ 3 , NKODE, KF LOW

COMMON/SPARAM/ TMAX, CDLT,DELT,ERR, TEST, SUM,SUMP, 2R, BETA 1 COMMON /SARRAY/ ICHK(13), LEVEL1(9), LEVEL2(9)

$N 3=1$

N $7=-1$

RETURN

$\cos 0170$

$\operatorname{coF} 0180 *$

COF0190*

COFO200

COF 0210

COF 0220

COFO230

C

- COMPUTE TRANSMISSIVITY FOR UPPER HYDROLOGIC UNIT WHEN

$\operatorname{COF} 0240$

IT IS UNCONFINED--

$* * * * * * * * * * * * * * * * * * * * *$

ENTRY TRANS (N3)

C

DO $10 \quad I=2, I 1$

DO $10 \mathrm{~J}=2, \mathrm{~J} 1$

IF (PERM(I,J).ER.O.) GO TO 10

$T(I, J, K O)=\operatorname{PERM}(I, J) *(\operatorname{PHI}(I, J, K O)-\operatorname{BOTTOM}(I, J))$

IF $(T(I, J, K O) . G T . O$.$) GO TO 10$

IF (WELL(I,J,KO).IT.0.) WRITE $(6,60)$ I,J,KO

IF (WELI $(I, J, K O), G E, 0$.$) WRITE (6,70) I, J, K O$

$\operatorname{PERM}(I, J)=0$.

$T(I, J, K O)=0$.

$T R(I, J-1, K O)=0$.

$T R(I, J, K O)=0$.

$T C(I, J, K O)=0$.

$T C(I-1, J, K O)=0$.

IF $(K O . N E .1) \quad T K(I, J, K 1)=0$.

$\operatorname{PHI}(I, J, K O)=1 . D 30$

10 CONTINUE

IF (N3.EQ.1) RETURN

$\mathrm{N} 1=\mathrm{KO}$

$N 2=K O$

$\mathrm{N} 4=\mathrm{K}$ i

GO TO 20

C ---COMPUTE T COEFFICIENTS---

C $\quad * * * * * * * * * * * * * * * * * * * * *$

ENTRY TCOF

C $\quad * * * * * * * * * * * * * * * * * * * * *$

$\aleph 7=N 7+1$

$N 1=1$

$\mathrm{N} 2=\mathrm{KO}$

COFO250

CoF0260

COFO270

COF 0280

COF 0290

COFO 300

COF 0310

COFO320

COFO 330

COFO340

COFO350

COF 0360

COF 0370

COFO380

COFO 390

COFO400

COF 0410

COFO 420

COFO430

COF 0440

COF 0450

COF 0460

COF 0470

COFO480

COF 0490

COrO500

COF 0510

COFO520

COF 0530

COF 0540

COF 0550

COF 0560

COFO570 
$I F(N 7 . G T .0) \quad N 2=K 1$

COF 0580

$N 4=1$

20 DO $40 \mathrm{~K}=N 1, N 2$

DO $40 \quad I=1, I 1$

DO $40 J=1, J 1$

IF $(T(I, J, K) . E Q .0$.$) GO TO 32$

IF $(T(I, J+1, K) . E 2.0$.$) GO TO 30$ $1 \mathrm{DELX}(J))$ *FACT $(K, 1)$

30 IF $(T(I+1, J, K) . E Q .0$,$) GO TO 32$

$T C(I, J, K)=(2, * T(I+1, J, K) * T(I, J, K)) /(T(I, J, K) * D E I Y(I+1)+T(I+1, J, K) * C 0 F 0680$ 1DELY (I))*FACT $(K, 2)$

$I F(T(I, J+1, K) . E 2.0$.$) . GO TO 32$

COF 0690

GO TO 40

$32 I F(T(I, J, K) \cdot E 2.0$.$) GO TO 33$ GO TO 34

$33 T R(I, J, K)=0$.

$T R(I, J-1, K)=0$.

$\operatorname{TC}(I, J, K)=0$.

$T C(I-1, J, K)=0$.

$T K(I, J, K)=0$.

IF (WELL $(I, J, K)$. IT.O.) GO. TO 80

$34 I F(T(I+1, J, K) . E Q .0$.$) GO TO 35$ GO TO 36

$35 \operatorname{TC}(I, J, K)=0$.

$T C(I+1, J, K)=0$.

$T K(I+1, J, K)=0$.

$36 \operatorname{IF}(T(I, J+1, K) . E Q .0$.$) GO TO 37$ GO TO 40

$37 \mathrm{TR}(I, J, K)=0$.

$T R(I, J+1, K)=0$.

$\operatorname{TK}(I, J+1, K)=0$.

40 CONTINUE

IF (KO.EQ.1.OR.ITK.EQ.ICHK (10).OR.N3.EQ.O) RETURN

DO $50 \quad K=N 4, K 1$

DO $50 \quad I=2, I 1$

DO $50 \quad J=2, J 1$

IF $(T(I, J, K+1) . E Q .0$.$) GO TO 50$

$T 1=T(I, J, K) * F A C T(K, 3)$

$T 2=T(T, J, K+i) * F A C T(K+1,3)$

$T K(I, J, K)=(2 . * T 2 * T 1) /(T 1 * D E L Z(K+1)+T 2 * D E L Z(K))$

50 CONTINUE

GO TO 100

80 WRITE $(6,73) \quad I, J, K$

WRITE $(6,75)$

IERR $=\mathbf{2}$

CAIL OUTPUT

c

100 RETURN

COF 0700

COF 0710

COF0720

COF 0730

COF 0740

COF 0750

COF 0760

COF 0770

COF 0780

COF $0785 *$

COF0790

COF 0800

COFO 810

COFO820

COF0830

COFO 840

COF 0850

COF0860

COF 0870

COFO880

COF 0890

COF 0900

COFO910

coro920

COFO930

COF0940

COF0950

COF0960

COFO970

COFOg 80

COF0981

cofog82*

COFO983*

$\operatorname{COF} 0984$

COF0985

COF0990

COF 1000

$\operatorname{COF} 1010$

60 FORMAT ('-',201'*'),'WELI',2I3,' IN IAYER',I3,', GOES DRY',20('*'))COF1020

70 FORMAT ('-',20('*'), 'NODE', 2I3,' IN LAYER', I3,' GOES DRY', 20('*')

73 FORMAT' '-',20('*'),' WELI', 2I3,' IN LAYER', I3,' GOES DRY--DEWATECOF1031* IRED OR SALINE-WATER INTRUSION ', $20(' *$ '))

$\operatorname{COF} 1032 *$

75 FORMAT $('-', 5 X, ' * * *$ EXECUTION TERMINATING-DISCHARGING WELL NODE (NOCOF 1033* $1 T$ IN TOP LAYER) GOES DRY--CHECK FOR SW INTRUSION ***'/10X,'THE FOLCOF1034* 2LOWING OUTPUT REPRESENTS STATE OF SOLUTION WHEN WELL WENT DRY') COF 1035* 
SUBROUTINE DATAICPHI, STRT, OLD,T,S,TR,TC,TK, WELI, DELX, DELY, DELZ, FACDATOO 10 1.T, PERM, BOTTOM, QRE,

2IDR, RH, RC, RB)

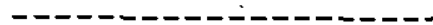
DATO0 00

SPECIFICATIONS :

DATOOTO 0070

REAL *8PHI

DATOO 00

REAL * 8 XIABL, YLABEL, TITLE, XN 1, MESUR

DIMENSION PHI(IO,JO,KO) , STR (IO, J

1), $S(I 0, J 0, K O), T R(I 0, J 0, K 0)$, TC $(I 0, J 0, K O), T K(I K, J K, K 5)$, WELL(IO, DATO 130 $2 J 0, K O)$, DELX(JO), DEIY(IO), DELZ(KO), FACT(KO,3), PERM(IP,JP), BOTDATO140 $3 T O M(I P, J P\}$, QRE(IQ,JQ), TF(3), A(IO,J0), IN(6), IOFT(9), INFT(2) DATO150

C $4, \operatorname{IDR}(I 0, J 0, K O), R H(1), R C(1), R B(1)$

COMMON/INTEGR/ IO,JO,KO,I 1,J1,K1,I,J,K,NPER,KTH,ITMAX,IENGTH,KP,NDATO180

1 WEL, NUMT, IFINAI, IT, KT, IHEAD, IDRAW, IFLO, IERR, I2, J2, K2, IMAX, ITMX1, KCDATO 190

$2 \mathrm{H}$, IDK 1, IDK2, IWATER, IQRE, IP, JP, IQ, JQ, IK, JK, K5, IPU1, IPU2, ITK, IEQN DATO200

3 , NKODE, KFLOW

COMMON/SPARAM/ TMAX, CDLT,DELT,ERR, TEST,SUM,SUMP, QR, BETA 1

DAT0210*

COMMON /SARRAY/ ICHK (13), LEVEL1(9), LEVEL $2(9)$

DATO220*

COMMON/CK/ RLFIXT, STORT, QRET, CHST, CHDT,FIUXT, PUMPT, CFIUXT, FTXNT DATO24O*

COMMON /PR, XLABEL( 3), YLABEL (6), TITLE(6), XN1, MESUR, PRNT( 122), BLANKDATO250

$1(60), D I G I T(122), V F 1(6), V F 2(6), V F 3(7), X S C A L E, D I N C H, S Y M(17), X N(100), D A T 0260$

$2 Y N(13), N A(4), N 1, N 2, N 3, Y S C A L E, F A C T 1, F A C T 2$

DAT 0270

RETURN

DATO280

C

C

$\mathrm{c}$
$\mathrm{c}$
$\mathrm{C}$

C

C

c

C

C

c

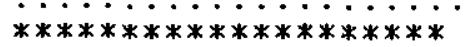

ENTRY DATAIN

$* * * * * * * * * * * * * * * * * * * *$

---READ AND WRITE SCALAR PARAMETERS---

READ $(5,330)$ NPER, KTH,ERR, LENGTH

WRITE $(6,340)$ NPER, KTH, ERR

$\begin{array}{ll}\text { WRITE }(6,340) \text { NPER,KTH,ERR } & \text { DATO360 }\end{array}$

1 VEL $2(I), I=1,9)$, MESUR

IF (XSCALE.NE.O.) WRITE $(6,470)$ XSCALE, YSCALE, MESUR, MESUR, DINCH, FADATO39O

1CT 1, LEVEL1, FACT 2, LEVEL 2

EAD CUMULATIVE MASS BALANCE PARAMETERS---

READ $(5,450)$ SUM, SUMP , PUMPT, CFIUXT, ORET, CHST, CHDT, FLUXT,STORT, ETFIDATO430

$1 \times T, F L X N T$

IF (IDK1.EQ.ICHK(4)) GO TO 20

IF (IPU1.NE.ICHK( 8)) GO TO 50

DO $10 \quad \mathrm{~K}=1, \mathrm{KO}$

DO $10 I=1, I 0$

10 READ $(5,360)$ ( $P H I(I, J, K), J=1, J 0)$

GO TO 30

- - READ INITIAL HEAD AND MASS BALANCE PARAMETERS FROM DISK--

20 READ (4) PHI, SUM, SUMP, PUMPT, CFLUXT, \&RET, CHST, CHDT, FLUXT, STORT, ETFLD IXT, FLXNT

REWIND 4
DATO300

DATO310

DAT 0320

DAT0330

DAT0 340

DAT0350

\section{DAT0380}

DAT0 400

DATO410

DATO420

DAT 0440

DAT0 450

DAT0 460

DATO470

DATO 480

DATO490

DAT0 500

DAT0510

DAT 0520

DAT 0530

DAT0 040

DAT0550

DAT0560

DAT0 570 


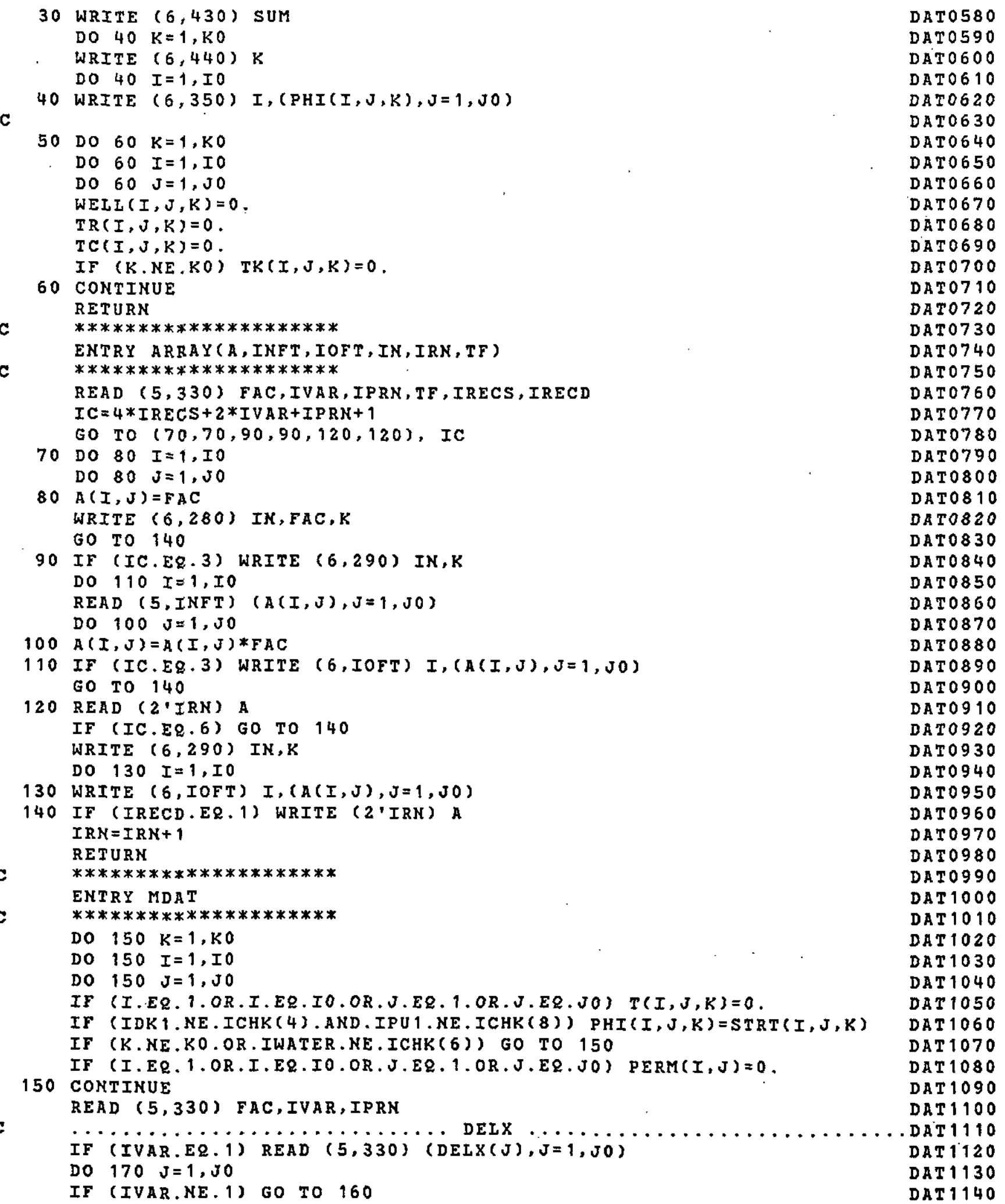


$\operatorname{DEIX}(\mathrm{J})=\operatorname{DEIX}(J) * F A C$

DAT 1150

GO TO 170

$160 \operatorname{DELX}(\mathrm{J})=\mathrm{FAC}$

170 CONTINUE

IF (IVAR.EQ.1,AND.IPRN.NE.1) WRITE $(6,370)(D E L X(J), J=1, J 0)$

DAT 1160

DAT 1170

IF (IVAR.EQ.0) WRITE $(6,300)$ FAC

DAT 1180

DAT 1190

DAT 1200

c

READ $(5,330)$ FAC, IVAR, IPRN

DAT 1220

IF (IVAR.EQ.1) READ $(5,330)$ (DEIY (I), I=1,IO)

DAT 1230

DO $190 \quad I=1, I 0$

IF (IVAR.NE.1) GO TO 180

DAT 1240

$\operatorname{DELY}(I)=D E I Y(I) * F A C$

DAT 1250

GO TO 190

180 DELY (I) $=$ FAC

190 CONTINUE

IF (IVAR.EQ.1.AND.IPRN.NE.1) WRITE (6,380) (DELY(I),I=1,IO)

DAT 1260

DAT 1270

DAT 1280

DAT 1290

IF (IVAR.EQ.0) WRITE $(6,310)$ FAC

DAT 1300

DAT 1310

C

READ $(5,330)$ FAC,IVAR, IPRN

IF (IVAR.EQ.1) READ $(5,330)(\operatorname{DEIZ}(K), K=1, K O)$

DO $210 \mathrm{~K}=1, \mathrm{KO}$

IF (IVAR.NE.1) GO TO 200

$\operatorname{DELZ}(K)=\operatorname{DELZ}(K) * F A C$

GO TO 210

200 DELZ $(K)=F A C$

210 CONTINUE

IF (IVAR.EQ.1.AND.IPRN.NE.1) WRITE $(6,390)$ (DELZ(K),K=1,KO)

C

IF (IVAR.EQ.0) WRITE $(6,320)$ FAC

c

-- IMITIALIZE VARIABLES---

$B=0$.

$D=0$.

$\mathbf{F}=0$.

$\mathrm{H}=0$.

$\mathrm{SU}=0$.

$\mathrm{Z}=0$.

IF (XSCALE.NE.O.) CALL MAP

RETURN

ENTRY DDAT2(NRIV)

$\mathrm{NK}=1$

DO $580 \mathrm{~K}=1, \mathrm{KO}$

DO $580 \quad I=1, I 0$

$\operatorname{READ}(5,510)(\operatorname{IDR}(I, J, K), J=1, J 0)$

DO $580 \mathrm{~J}=1, \mathrm{~J} 0$

$I F(I D R(I, J, K) . E Q .0)$ GO TO 580

$I D R(I, J, K)=N K$

$\mathrm{NK}=\mathrm{NK}+1$

580 CONTINUE

$\mathrm{NK}=\mathrm{NK}-1$

IF (NK.EQ.NRIV) GO TO 600

WRITE $(6,520) \mathrm{KK}, \mathrm{NRIV}$

STOP

600 READ $(5,330)$ FAC

$\operatorname{READ}(5,560)$ (RH(I), $I=1, N R I V)$

DO $610 I=1$, NRIV

$610 \mathrm{RH}(I)=\mathrm{RH}(I) * F A C$

WRITE $(6,540)$ (RH (I), I=1, NRIV)

DAT 1320

DAT 1330

DAT 1340

DAT 1350

DAT 1360

DAT 1370

DAT 1380

DAT 1390

DAT 1400

DAT 1410

DAT 1420

DAT 1430

DAT 1440

DAT 1450

DAT 1460

DAT 1470

DAT 1480

DAT 1490

DAT 1500

DAT 1510

DAT 1520

DAT $1530 *$

DAT 1540*

DAT 1550*

DAT $1560 *$

DAT 1570*

DAT 1580*

DAT1590*

DAT 1600*

DAT1610*

DAT 1620*

DAT $1630 \%$

DAT 1640*

DAT 1650*

DAT $1660 \%$

DAT 1670*

DAT $1680 *$

DAT $1690 *$

DAT $1700 *$

DAT1710* 
READ $(5,330)$ FAC

$\operatorname{READ}(5,560)$ (RB(I), I=1,NRIV)

DAT 1720* DO $620 I=1$, NRIV

$620 \mathrm{RB}(I)=\mathrm{RB}(I) * F A C$

WRITE $(6,545) \quad(R B(I), I=1, N R I V)$

READ $(5,33 C)$ FAC

$\operatorname{READ}(5,62.5) \quad(\operatorname{RC}(I), I=1, \operatorname{NRIV})$

DO $630 \quad I=1$, NRIV

$630 \mathrm{RC}(I)=\mathrm{RC}(I) * F A C$

WRITE $(6,635) \quad(R C(I), I=1, N R I V)$

DAT 1730*

DAT 1740*

DAT $1750 *$

DAT $1760 *$

DAT 1770*

DAT 1780*

DAT 1790*

DAT $1800 *$

DAT $1810^{*}$

RETURN

DAT $1820 *$

$\ldots \ldots$

DAT 1830

c

- - READ TIME PARAMETERS

UMPING DATA FOR A NEW PUMPING PERIOD $* * * * * * * * * * * * * * * * * * * * *$

ENTRY NEWPER

C $\quad * * * * * * * * * * * * * * * * * * * * *$

C

READ $(5,330)$ KP, KPM 1 , NWEL, TMAX, NUMT, CDIT, DELT

C

---COMPUTE ACTUAL DELT AND NUMT---

$\mathrm{DT}=\mathrm{DELT} / 24$.

$T M=0.0$

DO $220 \quad I=1$, NUMT

$D T=C D L T * D T$

$T M=T M+D T$

IF (TM.GE.TMAX) GO TO 230

220 CONTINUE

GO TO 240

230 DELT=TMAX/TM*DELT

NUMT $=I$

240 WRITE $(6,400)$ KP, TMAX, NUMT, DELT, CDLT

$D E L T=D E L T * 3600$

TMAX $=$ TMAX $* 86400$.

SUMP $=0.0$

c

---READ AND WRITE WELL PUMPING RATES---

WRITE $(6,410)$ NWEI

IF (NWEL,EQ.0) GO TO 260

DO $245 \mathrm{~K}=1, \mathrm{KO}$

DO $245 I=1, I 0$

DO $245 \mathrm{~J}=1, \mathrm{~J} 0$

$245 \operatorname{WELI}(I, J, K)=0.0$

DO $250 I I=1$, NWEL

READ $(5,330) K, I, J, W E L L(I, J, K)$

WRITE $(6,420) K, I, J, W E L I(I, J, K)$

250 WELI $(I, J, K)=W E L L(I, J, K) /(\operatorname{DELX}(J) * \operatorname{DELY}(I))$

C

260 RETURN

DAT 1850

DAT 1860

DAT 1870

DAT 1880

DAT 1890

DAT 1900

DAT 1910

DAT 1920

DAT 1930

DAT 1940

DAT 1950

DAT 1960

DAT 1970

DAT 1980

DAT.1990

DAT 2000

DAT 2010

DAT 2020

DAT 2030

DAT2040

DAT 2050

DAT 2060

DAT 2070

DAT 2080

DAT 2090

DAT 2100

DAT 2110

DAT 2120

DAT 2130

DAT 2140

DAT 2150

DAT 2160

DAT 2170

DAT 2180

DAT 2190

DAT2 200

DAT 2210

DAT 2220

DAT 2230

280 FORMAT ( 1 HO $52 X, 6 A 4^{\prime},=', 615.7,,^{\prime}$ FOR LAYER', I3)

DAT2240

290 FORMAT (1H1,45X,6A4,' MATRIX, LAYER', I $\left.3 / 46 X, 41()^{\prime}\right)$ )

DAT 2250

300 FORMAT. ('0',72X, DELX $=*$, G15.7)

310 FORMAT ('0',72X,'DELY $=1$, G15.7)

320 FORMAT $(0,, 72 X, \cdot$ DEL $=1,615.7)$ 
330 FORMAT ( 8 G 10.0$)$

DAT 2290

340 FORMAT ('0',51X,'NUMBER OF PUMPING PERIODS $=1$, I5/49X,'TIME STEPS BDATZ3OO

1ETWEEN PRINTOUTS =', I5//51X,'ERROR CRITERIA FOR CLOSURE =', G15.7/, DAT2310

350 FORMAT ('O', I2, $2 X, 20 F 6.1 /(5 X, 20 F 6.1))$

36 FORMAT $(8 F 10.4)$

DAT 2320

370 FORMAT (1H1,46X,40HGRID SPACING IN PROTOTYPE IN X DIRECTION/47X,40DAT2340 $1(\cdot-1) /(10 ', 12 F 10.0))$ DAT2 350

380 FORMAT (1H-,46X,40HGRID SPACING IN PROTOTYPE IN Y DIRECTION/47X,40DAT2360 $1(\cdot-1) /(\cdot 0), 12 \mathrm{~F} 10.0))$

DAT 2370

390 FORMAT (1H-,46X,40HGRID SPACING IN PROTOTYPE IN Z DIRECTION/47X,40DAT2380 $1(\cdot-1) / /(, 0 ', 12 F 10.0))$

DAT 2390

400 FORMAT ("-',50X,'PUMPING PERIOD NO.',I4,'", F10.2,' DAYS'/51X,38C'DAT2400

$1-1) / 53 X, '$ NUMBER OF' TIME STEPS $=1, I 6 / / 59 X, ' D E L T$ IN HOURS $=1, F 10.3 / / D A T 2410$

$253 \times$, 'MUITIPLIER FOR DEIT $=$ ', F10.3) DAT 2420

410 FORMAT ('-',63X,I4,' WELLS'/65X,9('-')//50X,'K',9X,'I',9X,'J PUDAT2430 1MPING RATE'/)

$420^{\circ}$ FORMAT $(41 X, 3 I 10,2$ F 13,2$)$

430 FORMAT ('-',40X,' CONTINUATION - HEAD AFTER ', G20.7," SEC PUMPING DAT 2440 DAT 2450 1'/42X,58('-1))

450 FORMAT (4G20.10)

460 FORMAT ( $3 G 10.0,2$ (G10.0,9I1,1X), A 8)

DAT 2490

DAT 2500

470 FORMAT ('0',30X, 'ON ALPHAMERIC MAP:'/40X, 'MULTIPLICATION FACTOR FODAT2510 $1 R \times$ DIMENSION $=$ ', G $15.7 / 40 X$, 'MULTIPLICATION FACTOR FOR Y DIMENSION DAT2520 $2='$, G 15.7/55X,'MAP SCALE IN UNITS OF ', A11/50X,'NUMBER OF',A8,'PDAT2530 3ER INCH =', G15.7/43X,'MULTIPIICATION FACTOR FOR DRAWDOWN =', G 15.7,DAT2540 4' PRINTED FOR LAYERS', 9I2/47X, 'MULTIPLICATION FACTOR FOR HEAD =', GDAT2550 $515.7, '$ PRINTED FOR LAYERS', 9IZ)

DAT 2560 DAT 2570 510 FORMAT $(80$ I 1$)$

520 FORMAT (' ERROR**** NK.NE.NRIV NK=',I5, 5X, 'NRIV=', I5) DAT 2580*

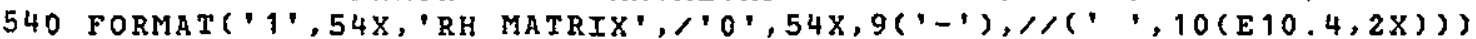

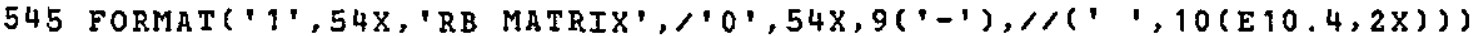

560 FORMAT (20F4.0)

625 FORMAT $(10 F 8.0)$

635 FORMAT('1',54X,'RC MATRIX', / $\left.0^{\prime}, 54 \mathrm{X}, 9\left(^{\prime}-0^{\prime}\right), / /\left({ }^{\prime}, 10(\mathrm{E} 10.4,2 \mathrm{X})\right)\right)$ DAT 2590* DAT $2600 *$ DAT 2610 DAT2 620 END

DAT2630* DAT2640 
SUBROUTINE CHECKI(PHI,STRT, OLD,T,S,TR,TC,TK, WELL, DELX, DELY, DELZ, FACHKOO10 ICT, JFLO, FLOW, QRE,

CHKOO2O

$2 I D R, R H, R C, R B, I R I V)$

CHKO030*

-

COMPUTE A VOLUMETRIC BALANCE

CHKOO50

-

SPECIFICATIONS :

REAL *8PHI

CHKOO60

CHKO070

CHKOO 0

CHKOO9O

CHKO 100

DIMENSION PHI(IO,JO,KO), STRT(IO,JO,KO), OID(IO,JO,KO), T(IO,JO,KOCHKOI10

1), $\mathrm{S}(I 0, J 0, K O), T R(I O, J 0, K O), T C(I O, J O, K O), T K(I K, J K, K 5), W E I L(I 0, C H K O 120$

2J0,KO), DELX(JO), DELY(IO), DELZ(KO), FACT(KO,3), JFLO(NCH,3), FLOCHKO130

$3 W(\mathrm{NCH}), \quad 2 \mathrm{RE}(I Q, \mathrm{~J} Q)$

$4, \operatorname{IDR}(I 0, J 0, K 0), R H(1), R C(1), R B(1)$

CHKO 140

C

COMMON /INTEGR/ IO,JO,KO,I $1, \mathrm{~J} 1, \mathrm{~K} 1, I, J, K, N P E R, K T H, I T M A X, I E N G T H, K P, N C H K O 170$

1WEL, NUMT, IFINAL, IT, KT, IHEAD, IDRAW, IFLO, IERR, I2, J2, K2, IMAX, ITMX 1, MCCHKO 180

$2 \mathrm{H}, I D K 1, I D K 2$, IWATER, IQRE, IP, JP, IQ, JQ, IK, JK, K5, IPU 1 , IPU $2, I T K, I E Q N$

3 , NKODE, KF LOW

COMMON/SPARAM/ TMAX, CDLT,DELT,ERR, TEST,SUM,SUMP, QR, BETA 1

COMMON/SARRAY/. ICHK( 13), LEVEL1(9), LEVEL $2(9)$

COMMON/CK/ RLFLXT, STORT, QRET, CHST, CHDT, FLUXT, PUMPT, CFLUXT, FLXNT RETURN

CHKO 190

CHKO200*

CHKO210*

CHKO220

CHKO230*

CHKO 240

C

*********************

CHKO250

ENTRY CHECK

$* * * * * * * * * * * * * * * * * * * *$

$\mathrm{CHKO} 260$

CHKO270

CHKO 280

- - INITIALIZE VARIABLES---

CHKO290

$P U M P=0$.

$S T O R=0$.

$F \mathrm{I} U \times S=0.0$

CHKO 300

CHKO 310

CHKO 320

CHD $1=0.0$

CHD2 $=0.0$

CHKO330

QREFLX $=0$.

CHKO 340

CFIUX $=0$.

$F L U X=0$.

CHKO 350

CHKO 360

RLFLUX $=0$.

CHK0370

$F L X N=0.0$

CHKO380*

$I I=0$

CHKO 390

CHKO400

c

IF (MOD (KT,KTH).EQ. O.OR.IFINAL,EQ. 1) WRITE $(6,5900)$

CHKO 410

C

C 
$J F I O(I I, 2)=I$

$J F I O(I I, 3)=J$

IF $(S(I, J-1, K) . I T .0 . O R, T(I, J-1, K) . E Q .0$.$) GO TO 30$

$X=(P H I(I, J, K)-P H I(I, J-1, K)) * T R(I, J-1, K) * D E L Y(I)$

IF (IEON.EQ. ICHK(11)) $X=X * D E I Z(K)$

$F L O W(I I)=F L O W(I I)+X$

IF (KFLOW. NE. 1) GO TO 5

IF (ABS $(X) . L T .0 .00001)$ GO TO 5

$M=J-1$

WRITE $(6,6000) \quad I, J, K, I, M, K, X$

INDEX $=1$

5 IF (X) $10,30,20$

$10 \mathrm{CHD} 1=\mathrm{CHD} 1+\mathrm{X}$

GO TO 30

20 CHD $2=\mathrm{CHD} 2+\mathrm{X}$

30 IF $(S(I, J+1, K), I T .0 \ldots$. OR.T(I,J+1,K).EQ.0.) GO TO 60

$X=(P H I(I, J, K)-P H I(I, J+1, K)) * D E L Y(I) * T R(I, J, K)$

IF (IEQN.EQ.ICHK(11)) $X=X * D E L Z(K)$

FLOW $(I I)=F L O W(I I)+X$

IF (KFLOW. NE.1) GO TO 35

IF (ABS (X).LT.0.00001) GO TO 35

$M=J+1$

IF(INDEX,EQ.0) WRITE $(6,6000) \quad I, J, K, I, M, K, X$

INDEX $=1$

WRITE $(6,6100) I, M, K, X$

35 IF (X) $40,60,50$

40 CHD $1=C H D 1+X$

GO TO 60

50 CHD2 $=\mathrm{CHD} 2+\mathrm{X}$

60 IF (K.EQ.1) GO TO 90

IF $(S(I, J, K-1) . \mathrm{L} .0 \ldots \mathrm{OR}, \mathrm{T}(I, J, K-1) . E Q .0$.$) GO TO 90$

$X=(\operatorname{PHI}(I, J, K)-\operatorname{PHI}(I, J, K-1)) * T K(I, J, K-1) * A R E A$

$F$ LOW $(I I)=F$ LOW $(I I)+X$

IF (KFLOW. NE. 1) GO TO 65

$I F(A B S(X)$.LT.0.00001) GO TO 65

$M=K-1$

IF(INDEX.EQ.0) WRITE $(6,6000) I, J, K, I, J, M, X$

INDEX $=1$

WRITE $(6,6100) I, J, M, X$

65 IF (X) $70,90,80$

$70 \mathrm{CHD} 1=\mathrm{CHD} 1+\mathrm{X}$

GO TO 90

$80 \mathrm{CHD} 2=\mathrm{CHD} 2+\mathrm{X}$

90 IF (K.EQ.KO) GO TO 120

IF $(S(I, J, K+1), I T, 0 \ldots O R, T(I, J, K+1) . E 2.0$.$) GO TO 120$

$X=(P H I(I, J, K)-P H I(I, J, K+1)) * T K(I, J, K) * A R E A$

FLOW $(I I)=F L O W(I I)+X$

IF (KFLOW.NE.1) GO TO 95 .

IF (ABS $(X): I T .0 .00001)$ GO TO 95

$M=K+1$

IF(INDEX.EQ.0) WRITE $(6,6000) I, J, K, I, J, M, X$

$I N D E X=1$

WRITE $(6,6100) \quad I, J, M, X$

95 IF (X) $100,120,110$

$100 \mathrm{CHD} 1=\mathrm{CHD} 1+\mathrm{X}$

GO TO 120

110 CHD2 $=$ CHD2 $+\mathrm{X}$

CHKO 570

CHKO580

CHKO59O

CHK0600

CHKO 610

CHKO 620

CHKO630*

CHKO640*

CHKO 650*

CHKO660*

CHK0670*

CHK0690

CHKO 700

CHKO 710

CHK 0720

CHKO 730

CHK 0740

CHK 0750

CHK0 760

CHK0770*

CHKO $780 *$

CHK0790*

CHK0 800*

CHKO $810 *$

CHKO 820*

CHKO 830

CHKO 840

CHKO 850

CHKO 860

CHKO 870

CHKO 880

CHKO 890

CHKO 900

CHKO 9 10*

CHKO920*

CHKO930*

CHKO940*

CHKO950*

CHK0960*

CHKO 970

CHKO980

CHKO99O

CHK 1000

CHK 1010

CHK 1020

CHK 1030

CHK 1040

CHK 1050*

CHK 1060*

CHK 1070*

CHK 1080*

CHK1090*

CHK $1100 *$

CHK 1110

CHK 1120

CHK 1130

CHK 1140 
$120 I F(S(I-1, J, K) . I T, 0 \ldots O R . T(I-1, J, K) . E Q, 0$.$) GO TO 150$

CHK 1150

$X=(P H I(I, J, K)-P H I(I-1, J, K)) * T C(I-1, J, K) * D E L X(J)$

CHK 1160

IF(IEQN.EQ. ICHK(11)) $X=X * D E I Z(K)$

$F L O W(I I)=F L O W(I I)+X$

IF (KFLOW. NE. 1) GO TO 125

IF (ABS $(X) . I T .0 .00001)$ GO TO 125

$M=I-1$

IF (INDEX,EQ.0) WRITE $(6,6000) I, J, K, M, J, K, X$

INDEX $=1$

WRITE $(6,6100) M, J, K, X$

125 IF (X) $130,150,140$

$130 \mathrm{CHD} 1=\mathrm{CHD} 1+\mathrm{X}$

GO TO 150

140 CHD $2=C H D 2+X$

150 IF $(S(I+1, J, K) . I T .0 \ldots O R . T(I+1, J, K) . E Q .0$.$) GO TO 220$

$X=(P H I(I, J, K)-P H I(I+1, J, K)) * T C(I, J, K) * D E L X(J)$.

IF (IEQN.EQ.ICHK $(11)) \quad X=X * D E L Z(K)$

$F$ LOW $(I I)=F I O W(I I)+X$

$I F(K F L O W . N E .1)$ GO TO 155

IF $(A B S(X) . I T .0 .00001)$ GO TO 155

$M=I+1$

IF(INDEX.EQ.0) WRITE $(6,6000) I, J, K, M, J, K, X$

INDEX $=1$

WRITE $(6,6100) \mathrm{M}, \mathrm{J}, \mathrm{K}, \mathrm{X}$

155 IF (X) $360,220,170$

$160 \mathrm{CHD} \uparrow=\mathrm{CHD} 1+\mathrm{X}$

GO TO 220

$170 \mathrm{CHDZ}=\mathrm{CHD} 2+\mathrm{X}$

GO TO 220

c

C - -CHECK FOR EQUATION BEING SOLVED---

c

180 IF(IEQN.EQ.ICHK $(11)$ ) GO TO 211

C

- - EQUATION $4-\cdots$

$---R E C H A R G E$ AND WELLS- -

IF (K.EQ.KO.AND.IQRE.EQ.ICHK(7)) QREFIX

IF $(W E L L(I, J, K)) 190,210,200$

190 PUMP $=$ PUMP+WELL $(I, J ; K)$ *AREA

GO TO 210

c

$200 C F L U X=C F L U X+W E L L(I, J, K) * A R E A$

C --COMPUTE VOLUME FROM STORAGE---

$210 S T O R=S T O R+S(I, J, K) *(O L D(I, J, K)-P H I(I, J, K)) * A R E A$

IF (IRIV.IE.O) GO TO 220

C
C

---COMPUTE 'RIVER' IEAKAGE---

$N D=\operatorname{IDR}(I, J, K)$

IF(ND.EQ.O) GO TO 220.

IF (PHI (I,J,K).GT.RB(ND)) GO TO 217

$F L X R A T=R C(N D) *(R H(N D)-R B(N D)) * A R E A$

IF(KFIOW.EQ.1) WRITE $(6,6200)$ I,J:K,FLXRAT

RLFIUX = RLFLUX+FLXRAT

GO TO 220

217 FIXRAT $=$ RC (ND)*(RH(ND) -PHI $(I, J ; K)) * A R E A$

IF (KFLOW.EQ.1) WRITE $(6,6200)$ I,J,K,FLXRAT

RLFLUX = RIFLUX+FIXRAT

CHK 1180

CHK1190

CHK $1200 *$

CHK1210*

ChK 1220*

CHK $1230 *$

CHK 1240*

CHK 1250

CHK 1260

CHK 1270

CHK 1280

CHK 1290

CHK 1300

CHK 1310

CHK 1320

CHK $1330 *$

CHK 1340*

CHK 1350*

CHK $1350 *$

CHK $1370 *$

CHK 1380*

CHK 1390

CHK 1400

CHK 1410

CHK 1420

CHK-1430

CHK 1440

CHK 1450

CHK 1460

CHK 1470

CHK 1480

CHK 1490

CHK 1500

CHK 1510

CHK 1520

CHK 1530

CHK 1540

CHK 1550

CHK 1560

CHK 1570

CHK 1580*

CHK 1585*

CHK 1590*

CHK 1595*

CHK 1600*

CHK $1610 \%$

CHK 1620*

CHK 1630*

CHK 1640*

CHK 1650*

CHK 1660*

CHK $1670 *$

CHK 1680*

CHK $1690 *$ 


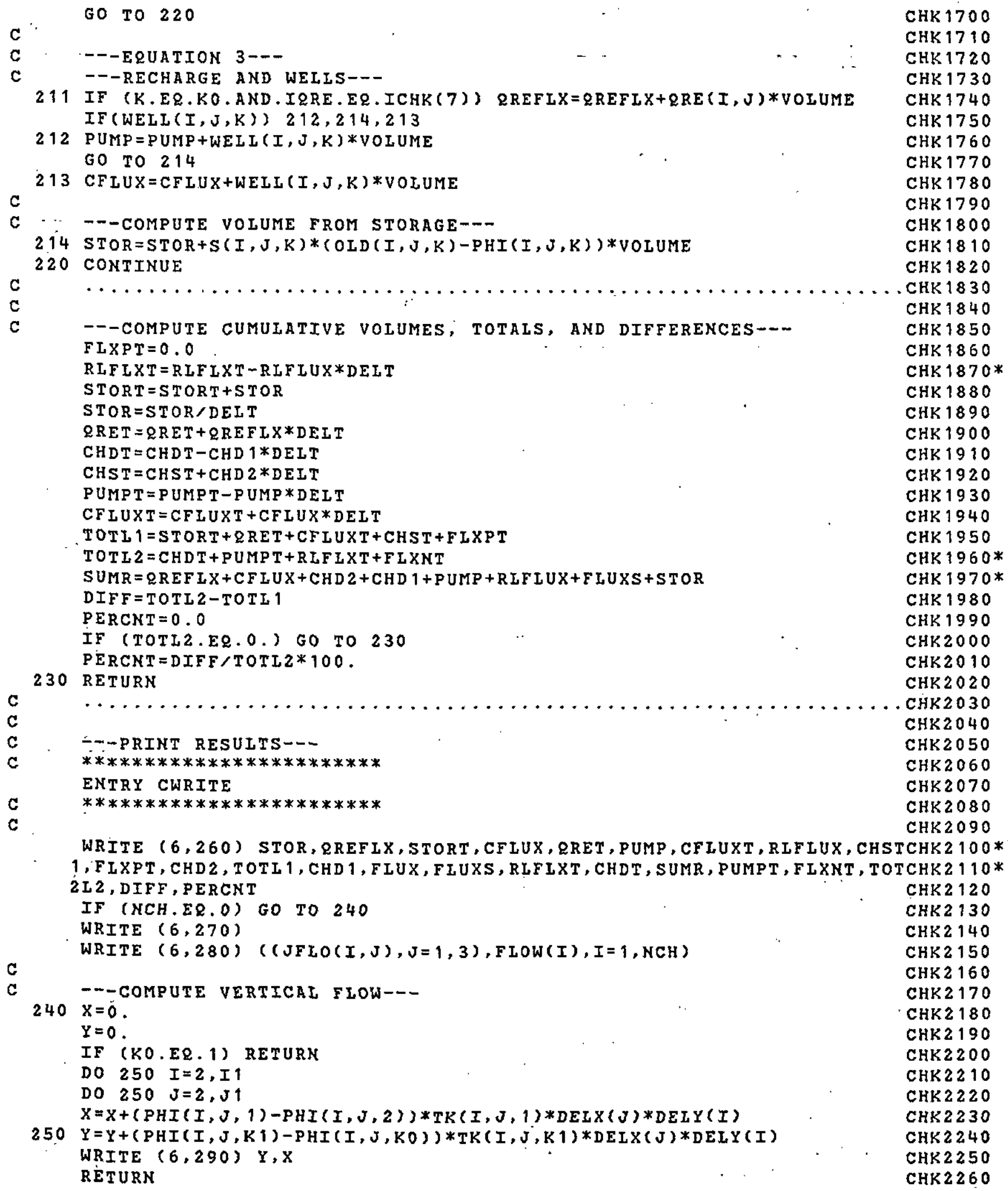




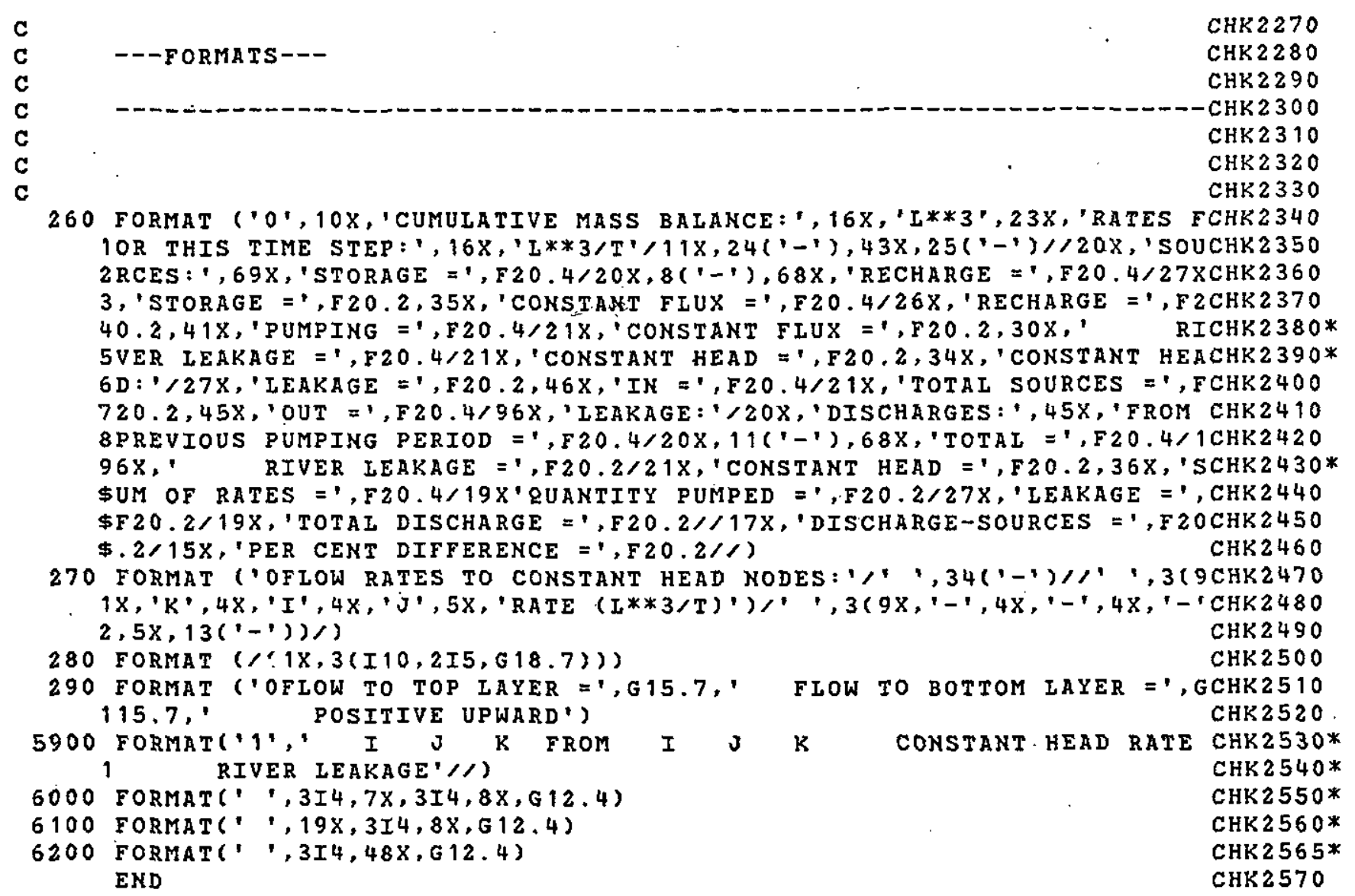

c. 
SUBROUTINE PRNTAI (PHI, STRT, T, S, WELL, DELX, DELY)

SPECIFICATIONS :

REAL *8PHI, Z, XIABEL, YLABEL, TITLE, XN1, MESUR

REAL $* 4 \mathrm{~K}$

PRNOO40

PRNO050

PRNO060

PRNO070

PRNO080

PRNO090

DIMENSION PHI(IO,JO,KO), STRT(IO,JO,KO), S(IO,JO,KO), WELISIO,JO,KPRNO100

10), DELX(JO), DELY(IO), T(IO,JO,KO)

PRNO 110

PRNO 120

COMMON /INTEGR/ IO,JO,KO,I1,J1,K1,I,J,K, MPER,KTH,ITMAX, IENGTH,KP, NPRNO 130 1 WEL, NUMT, IFINAL, IT, KT, IHEAD, IDRAW, IFLO, IERR, I2, J2, K2, IMAX, ITMX 1, XCPRNO140 $2 \mathrm{H}, I D K 1$, IDK2, IWATER, IQRE, IP, JP, IQ, JQ,IK, JK, K5, IPU I, IPU 2, ITK, IEQN PRNO150 3, NKODE, KFLOW

PRNO160*

COMMON /PR/ XLABEL( 3), YLABEL (6), TITLE( 6), XN1, MESUR, PRNT( 122), BLANKPRNO 170 $1(60), D I G I T(122), V F 1(6), V F 2(6), V F 3(7), X S C A I E, D I N C H, S Y M(17), X N(100), P R N 0180$ $2 Y N(13), N A(4), N 1, N 2, N 3, Y S C A L E, F A C T 1 ; F A C T 2$ PRNO190 RET.URN

PRNO200 
$N N X=N 5-I$

$N N Y=I-1$

PRNO590

PRNO600

IF (NNY.GE.N6) GO TO 50

PRNO6 10

$Y N(I)=Y S F * N N Y / Y S C A L E$

50 IF (NNX.IT.0) GO TO 60

$X N(I)=X S F * N N X / Y S C A L E$

60 CONTINUE

RETURN

PRNO620

PRNO6 30

PRNO640

PRN0650

PRNO660

PRN0670

c

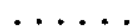

PRN0680

PRN0690

PRN0700

PRNO710

ENTRY PRNTA(NG, LA)

C $\quad * * * * * * * * * * * * * * * * * * * *$

C - -VARIABLES INITIALIZED EACH TIME A PLOT IS REQUESTED- -

PRN 0720

PRNO730

DIST $=$ WIDTH-DELX $(J 1) / 2$.

$\mathrm{J}=\mathrm{J} 1$

$L I=1$

$\mathrm{Z}=\mathrm{N} \times \mathrm{D} * \mathrm{XSF}$

IF (NG.EQ.1) WRITE $(6,300)$ (TITLE(I),I=1,3), LA

IF (NG.EQ.2) WRITE $(6,300)$ (TITLE(I),I=4,6), IA

C

DO $290 \quad I=1, N 4$

C D - LOCATE X AXES---

IF (I.EQ.1.OR.I.EQ.N4) GO TO 70

PRNT $(1)=S Y M(12)$

PRNT $(N 8)=S Y M(12)$

IF $((I-1) / N 1 * N 1 . N E . I-1)$ GO TO 90

PRNT $(1)=\operatorname{SYM}(14)$

$\operatorname{PRNT}(N 8)=$ SYM ( 14$)$

C

GO TO 90

$\mathrm{C}$

70 DO $80 \mathrm{~J}=1, \mathrm{~N} 8$

- - IOCATE Y AXES-D-

IF $((J-1) / N 2 * N 2, E Q \cdot J-1) \quad \operatorname{PRNT}(J)=\operatorname{SYM}(14)$

C

80 IF $((J-1) / N 2 * K 2 . N E \cdot J-1)$ PRNT(J)=SYM( 13$)$

C

- -COMPUTE LOCATION OF NODES AND DETERMINE APPROPRIATE SYMBOL- -

90 IF (DIST.LT.O.OR.DIST.IT.Z-XNI*XSF) GO TO 240

$Y L E N=D E L Y(2) / 2$.

DO $220 \mathrm{~L}=2$, I 1

$J=Y L E N * K 2 / Y S F+1.5$

IF $(T(I, J U, L A) . E Q .0$.$) GO TO 160$

IF $(S(I, J J, I A) . I T, 0$.$) GO TO 210$

$\operatorname{IND} \times 3=0$

GO TO $(100,110)$, NG

$100 \mathrm{~K}=(\operatorname{STRT}(L, J J, L A)-P H I(I, J J, I A)) * F A C T 1$

-TO CYCLE SYMBOLS FOR DRAWDOWN, REMOVE C FROM COI, 1 OF NEXT CAH-PRN1060

C $K=A M O D(K, 10$. GO TO 120

$110 \mathrm{~K}=\mathrm{PHI}(\mathrm{I}, \mathrm{JJ}, \mathrm{LA}) * \mathrm{FACT} 2$

120 IF (K) $130,160,140$

130 IF $(J-2 . G T .0) \operatorname{PRNT}(J-2)=\operatorname{SYM}(13)$

$N=-K+.5$

IF (N.IT.100) GO TO 150

GO TO 190

PRNO740

PRN0750

PRN0760

PRN0770

PRN0780

PRN0790

PRNO800

PRN0810

PRNO820

PRNO830

PRNO 840

PRN0850

PRN0860

PRN0870

PRNO 880

PRN0890

PRNO900

PRNO9 10

PRNO920

PRNO930

PRNO940

PRNO950

PRNO960

PRNO970

PRNO980

PRNO990

PRN 1000

PRN 1010

PRN 1020

PRN 1030

PRN 1040

PRN 1050

PRN 1070

PRN1080

PRN 1090

PRN 1100

PRM 1110

PRN 1120

PRN 1130

PRN1140 
$140 \quad K=K+.5$

IF (N.LT.100) GO TO 150

IF (N.GT.999) GO TO 190

INDX $3=N / 100$

IF $(J-2 . G T .0) \quad \operatorname{PRNT}(J-2)=\operatorname{SYM}(\operatorname{INDX3)}$

$\mathrm{N}=\mathrm{N}-\operatorname{INDX} 3 * 100$

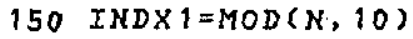

IF $(\operatorname{INDX1.EQ.0)} \operatorname{INDX} 1=10$

c -TO CYCLE SYMBOLS FOR DRAW

170 INDX $2=15$

180. IF $(J-1 . G T .0) \quad \operatorname{PRNT}(J-1)=\operatorname{SYM}(I N D \times 2)$

PRNT $(J)=S Y M(I N D X 1)$

GO TO 220

190 DO $200 \quad I I=1,3$

$J I=J-3+I I$

200 IF (JI.GT.0) PRNT(JI) $=S Y M(11)$

$210 I F(S(I, J J, L A) . I T .0.) \quad \operatorname{PRNT}(J)=S Y M(16)$

220 YLEN $=Y L E N+(D E L Y(L)+D E L Y(L+1)) / 2$.

$230 \operatorname{DIST}=D I S T-(D E L X(J J)+D E L X(J J-1)) / 2$.

$J J=J J-1$

IF (JJ.EQ.O) GO TO 240

IF (DIST.GT.Z-XN1*XSF) GO TO 230

c

240 CONTINUE

C -DPRINT AXES, LABELS, AND SYMBOLS---

IF (I-NA(IL).EQ.O) GO TO 260

$I F((I-1) / N 1 * N 1-(I-1)) 270,250,270$

250 WRITE $(6, \operatorname{VF} 1)(\operatorname{BLANK}(J), J=1, N C),(\operatorname{PRNT}(J), J=1, N 8), X N(1+(I-1) / 6)$ GO TO 280

260 WRITE $(6, V F 2)$ (BLANK $(J), J=1, N C),(\operatorname{PRNT}(J), J=1, N 8)$, XIABEL (IL)

$I L=L I+1$

GO TO 280

C

270 WRITE $(6, V F 2)(B L A N K(J), J=1, N C),(\operatorname{PRNT}(J), J=1, N 8)$

C

$280 \mathrm{z}=\mathrm{Z}-2$. *XN $1 * \mathrm{XSF}$

DO $290 \mathrm{~J}=1, \mathrm{~N} 8$

c

210 PRNT $(J)=\operatorname{SYM}(15)$ c

C

C
PRN1150

PRN 1160

PRN1170

PRN 1180

PRN 1190

PRN 1200

PRN 1210

PRN 1220

PRN 1230

PRN 1240

PRN 1250

PRN 1260

PRN 1270

PRN 1280

PRN 1290

PRN 1300

PRN 1310

PRN 1320

PRN1330

PRN 1340

PRN1350

PRN 1360

PRN 1370

PRN 1380

PRN 1390

PRN 1400

PRN1410

PRN 1420

PRM 1430

PRN 1440

PRN 1450

PRN 1460

PRN 1470

PRN 1480

PRN 1490

PRN1500

PRN 1510

PRN1520

PRN 1530

PRN 1540

PRN 1550

PRN 1560

PRN 1570

PRN 1580

PRN 1590

PRN 1600

PRN 1610

PRN 1620

PRN 1630

PRN 1640

PRN 1650

PRN 1660

PRN 1670

PRN 1680

PRN 1690

PRN 1700

PRN 1710 
300 FORMAT ('1',49X,3A8, 'LAYER',I4//)

PRN 1730

310 FORMAT ('OEXPLANATION" $/, 11\left({ }^{\prime}-'\right) / /$ R = CONSTANT HEAD BOUNDARY'/PRK1740 1. $* * *$ = VALUE EXCEEDED 3 FIGURES'/ MULTIPIICATION FACTOR =',F8.3)PRN1750 320 FORMAT $(10,39 \times, 6$ A 8$)$

330 FORMAT ('0',25X,10(*'),' TO FIT MAP WITHIN 12 INCHES, DINCH REVISPRN1770 1ED TO, G15,7,1X,10(,

340 FORMAT ('0", $45 \mathrm{X}$, "NOTE: GENERALIY SCALE SHOULD BE $>$ OR $=1.0^{\prime}$ )

PRN 1780 END

PRN 1790

PRN 1800 
SPECIFICATIONS:

BIKOO 30

REAL * 8XLABEL, YLABEL, TITLE, XN1, MESUR

$B L K 0040$

$B L K 0050$

COMMON /SARRAY/ ICHK(13), IEVEL1(9), IEVEL2 (9)

BIKOO60

COMMON /PR/ XIABEI( 3 ), YLABEL(6), TITLE(6), XN1, MESUR,PRNT(122), BLANKBLKOO8O $1(60), \operatorname{DIGIT}(122), V F 1(6), V F 2(6), V F 3(7), X S C A L E, \operatorname{DINCH}, \operatorname{SYM}(17), X N(100), B L K 0090$ $2 Y N(13), N A(4), N 1, N 2, N 3, Y S C A I E, F A C T 1, F A C T 2$

$B L K 0100$

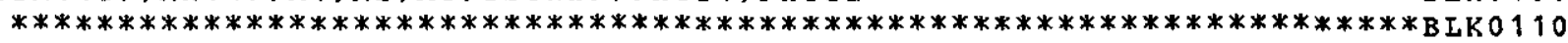

BLKO120

DATA ICHK/'DRAW', 'HEAD', 'MASS', 'DK1', 'DK2', 'WATE', 'RECH', 'PUN'', 'PBLKO130 IUN2', 'ITKR', 'EQN3', $2 * 0 /$ BIKO 140

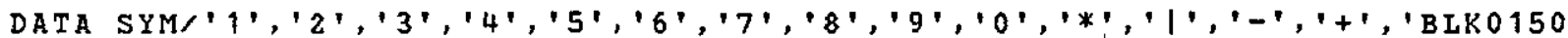
$1, R^{\prime}, ' W$ ' $8 L K 0160$

DATA PRNT/122*', $, N 1, N 2, N 3, X N 1 / 6,10,133, .833333333 \mathrm{D}-1 /, \mathrm{BLANK} / 60 * \cdot \mathrm{BLKO} 170$ $1, N$, NA (4)/1000/

$B L K 0180$

DATA XLABEL/ X DIS- ', 'TANCE IN',' MILES ', YLABEL/'DISTANCE', BIKO190 IFROM OR', 'IGIN IN ', 'Y DIRECT', 'ION, IN ', 'MILES ',TITLE/'PLOT BLKOZOO 2OF ', 'DRAWDOWN',' ', 'PLOT OF ', 'HYDRAUII', 'C HEAD',

BLKO2 10

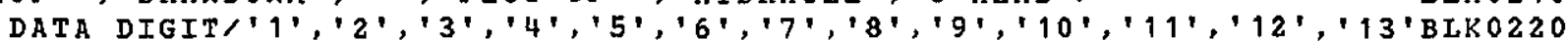

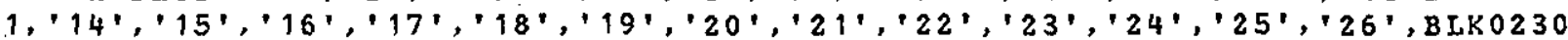

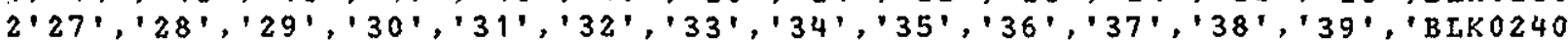

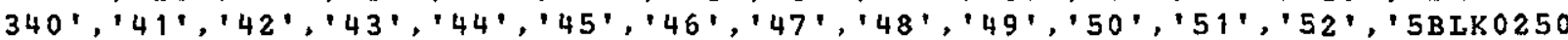

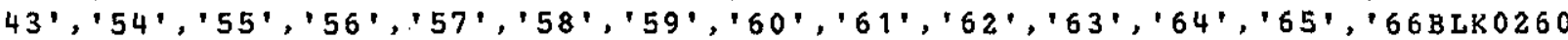

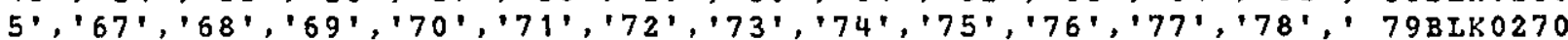

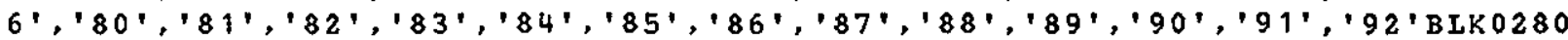

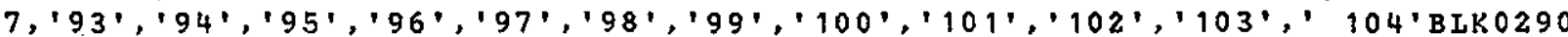

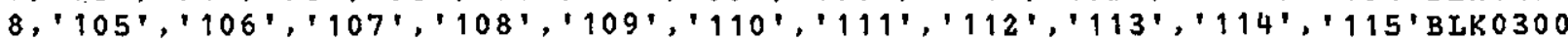
$9, ' 116^{\prime}, ' 117^{\prime}, ' 118^{\prime}, ' 119^{\prime}, ' 120^{\prime}, ' 121^{\prime}, ' 122^{\prime}$ ', DATA VFY, (1H',', ', ', '1,F', 10.2','), BLK0310 DATA VF2, (1H,', ', 'A 1, 1, , X, A ', ', DATA VF3/'(1HO',',', ', 'A $\left.1, F^{\prime}, ' 3,1,1,12 \mathrm{~F} 1,10.2\right) '$ BIKO 320 BLKO 0330 B LKO 340

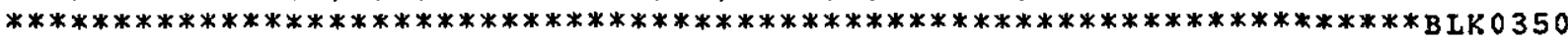
END

BLKO 360 